UNIVERSIDADE DE SÃO PAULO

FACULDADE DE FILOSOFIA, LETRAS E CIÊNCIAS HUMANAS

DEPARTAMENTO DE LETRAS CLÁSSICAS E VERNÁCULAS

MARCOS EDUARDO MELO DOS SANTOS

A declamação "Queixa da Paz” de Erasmo de Rotterdam:

estudo introdutório e tradução (Edição bilíngue)

Versão corrigida

São Paulo

2017 
Marcos Eduardo Melo dos Santos

\title{
A declamação “Queixa da Paz” de Erasmo de Rotterdam: estudo introdutório e tradução (Edição bilíngue)
}

\author{
Versão corrigida
}

Dissertação apresentada à Faculdade de Filosofia, Letras e Ciências Humanas da Universidade de São Paulo para a obtenção do título de Mestre em Letras Clássicas.

Área de Concentração: Letras Clássicas

Orientação: Elaine Cristine Sartorelli

São Paulo 
Autorizo a reprodução e divulgação total ou parcial deste trabalho, por qualquer meio convencional ou eletrônico, para fins de estudo e pesquisa, desde que citada a fonte.

Catalogação na Publicação

Serviço de Biblioteca e Documentação

Faculdade de Filosofia, Letras e Ciências Humanas da Universidade de São Paulo

$\mathrm{Sd}$

Santos, Marcos Eduardo Melo dos

A declamação "Queixa da Paz" de Erasmo de

Rotterdam: estudo introdutório e tradução (Edição

bilíngue) / Marcos Eduardo Melo dos Santos ;

orientadora Elaine Cristine Sartorelli. - São Paulo, 2017.

$228 \mathrm{f}$.

Dissertação (Mestrado) - Faculdade de Filosofia, Letras e Ciências Humanas da Universidade de São Paulo. Departamento de Letras Clássicas e

Vernáculas. Área de concentração: Letras Clássicas.

1. retórica. 2. recepção dos clássicos. 3.

humanismo. 4. Erasmo de Rotterdam. 5. declamação. I. Sartorelli, Elaine Cristine, orient. II. Título. 


\section{FOLHA DE APROVAÇÃO}

NOME: SANTOS, Marcos Eduardo Melo dos.

TÍTULO: A declamação "Queixa da Paz" de Erasmo de Rotterdam: estudo introdutório e tradução (Edição bilíngue).

Dissertação apresentada à Faculdade de Filosofia, Letras e Ciências Humanas da Universidade de São Paulo para obtenção do título de Mestre em Letras Clássicas.

Aprovado em 04/08/2017

Banca Examinadora

Prof. Dr. Edelcio Gonçalvez de Souza (Presidente)

Instituição: Universidade de São Paulo (USP)

Profa. Dra. Ana Cláudia Romano Ribeiro

Instituição: Universidade Federal de São Paulo (UNIFESP)

Profa. Dra. Leni Ribeiro Leite

Instituição: Universidade Federal do Espírito Santo (UFES)

Profa. Dra. Charlene Martins Miotti

Instituição: Universidade Federal de Juiz de Fora (UFJF) 


\section{AGRADECIMENTOS}

Em primeiro lugar, aos meus pais, Emanuel e Luiza. À minha esposa Susana, meu filho Felipe e aos meus irmãos, Emanuel, Luiz e Hugo.

À Professora Doutora Elaine Cristine Sartorelli, que orientou incansavelmente cada etapa do trabalho e sempre permitiu a liberdade para adoção ou não de suas sugestões. Devo reconhecer todo seu empenho. Guardarei admiração pela sua competência e gratidão por tudo que com ela aprendi.

Não poderia deixar ainda de manifestar minha gratidão a tudo que o Professor Doutor Pablo Schwartz Frydman e a Doutoranda Bárbara Costa e Silva, ambos dedicados pesquisadores das antigas declamações, contribuíram para o aprofundamento e a correção do estudo introdutório. Aos professores Paulo Vasconcellos e Pablo Schwartz Frydman que fizeram várias sugestões pertinentes durante o exame de qualificação, tanto no texto introdutório, quanto na tradução.

Ao corpo docente da Faculdade de Filosofia, Letras e Ciências Humanas da Universidade de São Paulo, que com muito esmero, excelência e solicitude me acompanharam nessa etapa, especialmente aos Professores Doutores José Eduardo Lohner, Pablo Schwartz Frydman, Márcio Suzuki, Maurício de Carvalho Ramos e Luiz Antônio Lindo, que também concederam indicações durante o trabalho de conclusão da disciplina que com eles cursei ao longo do mestrado. Não poderia ser omisso em agradecer à banca examinadora que com gentileza e competência arguiram e indicaram modificações no trabalho.

À amiga, Professora Doutora Vanessa Guimarães Monteiro Ferreira da Costa, que também fez observações significativas no que se refere à tradução. Ao Professor Doutor Marc van der Poel que gentilmente enviou por correio seus artigos e livros sobre a declamação, não disponíveis à venda, a fim de contribuir com esta pesquisa. Aos professores de Língua Portuguesa, meus amigos, que incansavelmente me auxiliaram na redação, revisão e discussões de opções de redação, nomeadamente, Letícia Mendes Ferri, Luiz Santos, Susana Aparecida da Silva, Regina Berti, Sarah Barbosa e Weber Suhett. 


\section{RESUMO}

SANTOS, Marcos Eduardo Melo dos. A declamação "Queixa da paz" de Erasmo de Rotterdam: estudo introdutório e tradução (Edição bilíngue). 2017. 228 f. Dissertação (Mestrado) - Faculdade de Filosofia, Letras e Ciências Humanas, São Paulo, 2017.

Este trabalho propõe a primeira tradução feita diretamente do latim para o português brasileiro de uma das obras mais importantes do humanista Erasmo de Rotterdam: a Querela Pacis undique gentium eiectae profligataeque, publicada em 1517. Tal obra constitui-se, ao lado de outros escritos, como uma das mais importantes declamações realizadas durante o Renascimento. Nossa transposição para o português considerará os recursos retóricos escritos em latim, além de conter notas explicativas e referências históricas, mitológicas e bibliográficas, sempre que estas se fizerem necessárias para melhor compreensão do texto, além de referências a autores da Antiguidade assim como a outras obras do próprio autor. No estudo introdutório dessa obra de gênero declamatio renascentista, procurar-se-á analisar o texto erasmiano segundo a conceituação da retórica tradicional antiga, sobretudo dos autores do período imperial, quando a prática das declamações escritas em grego e latim se sobrepôs à oratória, sem espaço em razão do declínio senatorial. Com base nas fontes antigas e nos estudos recentes, pretendemos identificar as semelhanças e diferenças entre a retórica dos autores romanos e a erasmiana nela concretizada. Também serão investigadas as estratégias da argumentação persuasiva, sejam epidíticas, sejam deliberativam, em favor da paz e em sua polêmica diatribe contra a guerra.

Palavras-chave: retórica; recepção dos clássicos; humanismo; Erasmo de Rotterdam; declamação. 


\begin{abstract}
SANTOS, Marcos Eduardo Melo dos. The "Complaint of Peace" declamation by Desiderius Erasmus: introduction and translation (Bilingual edition). 2017. 228 f. Dissertação (Mestrado) - Faculdade de Filosofia, Letras e Ciências Humanas, São Paulo, 2017.

This paper proposes the first translation directly from Latin into Brazilian Portuguese of one of the most important works by the humanist Desiderius Erasmus: Querela Pacis undique gentium eiectae profligataeque, published in 1517. This work constitutes one of the most important declamations written during the Renaissance. Our transposition to Portuguese will consider rhetorical resources, as well as containing explanatory notes about historical, mythological and bibliographical references, whenever these are necessary for a better understanding of the text, such as references to direct or indirect allusions to writings of Antiquity or other works by the author himself. In the introductory study of this work of the Renaissance declamatio genre, we will analyze the Erasmian text according to the ancient traditional Greco-Roman concept of Rethoric, especially in the authors of the imperial period, when the practice of declamations written in Greek and Latin overlapped the oratory without the ancient status because of the senatorial decline. Based on ancient sources and recent studies, we intend to identify the similarities and differences between the rhetoric of classic Latin authors and the erasmian rhetoric embodied in the Complaint of Peace. We will also investigate the strategies of persuasive argumentation, whether epididical or deliberative, in favor of peace and in its controversial diatribe against war.
\end{abstract}

Keywords: rhetoric; classical reception; humanism; Desiderius Erasmus; declamation. 



\section{SUMÁRIO}

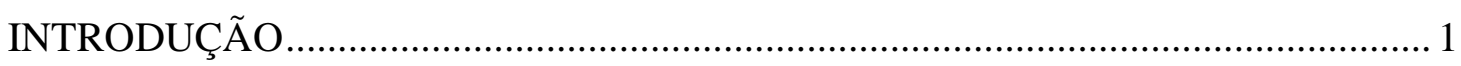

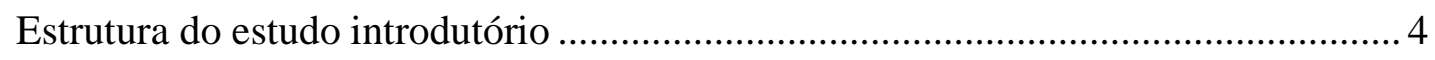

Estudos e publicações precedentes sobre o objeto de pesquisa ................................ 5

CAPÍTULO 1 - O GÊNERO DECLAMAÇÃO E SUA RECEPÇÃO NO

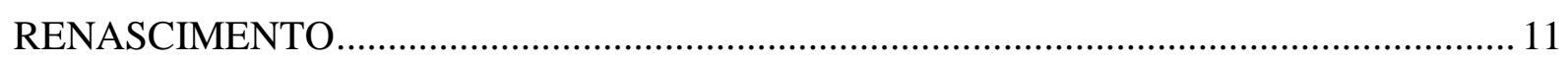

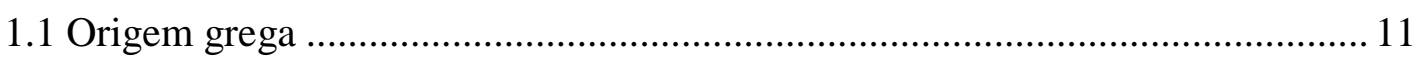

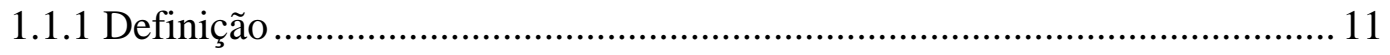

1.1.2 Principais autores e escritos em grego ................................................. 14

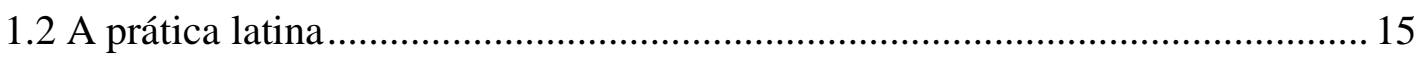

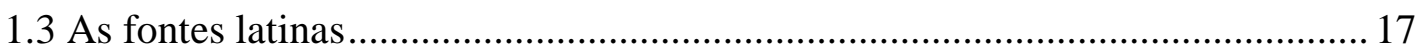

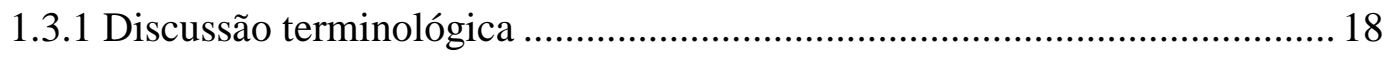

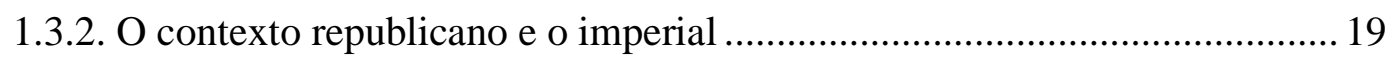

1.4 A declamação segundo os autores latinos........................................................ 22

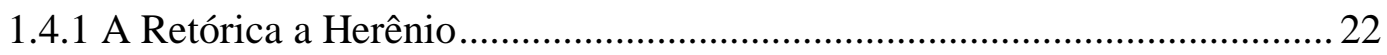

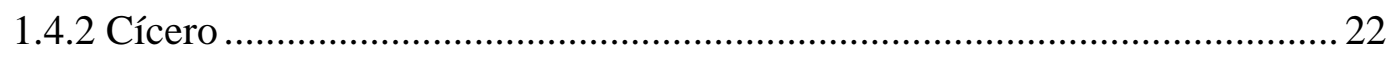

1.4.3 Sêneca, o Rétor ou o Velho ................................................................... 23

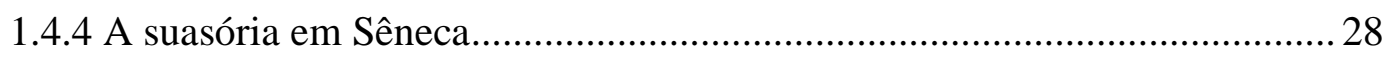

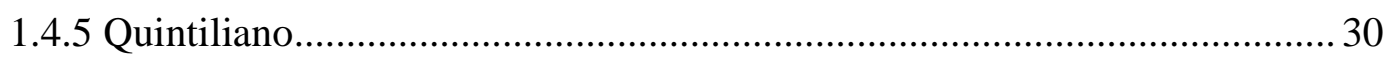

1.5 A recepção dos autores antigos no Renascimento .......................................... 35

1.6 A recepção pelas edições e traduções dos autores antigos ................................ 39

1.7 Principais declamadores e declamações renascentistas .................................. 42

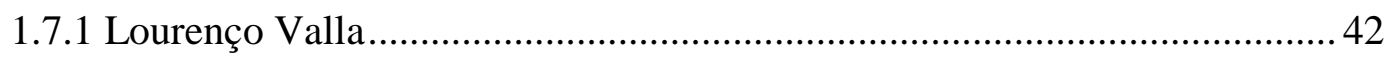

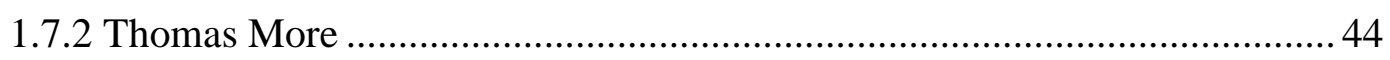


1.8 Classificação das declamações renascentistas .................................................. 45

1.9 Definições da declamação pelos renascentistas ................................................... 47

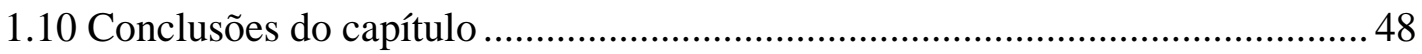

CAPÍTULO 2 - A DECLAMAÇÃO ERASMIANA E A QUEIXA DA PAZ ............... 51

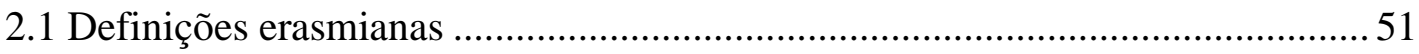

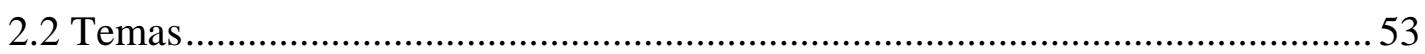

2.3 Contato de Erasmo com declamações precedentes............................................. 56

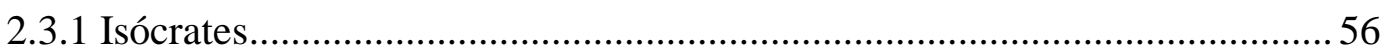

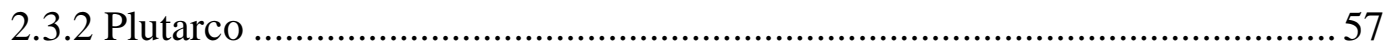

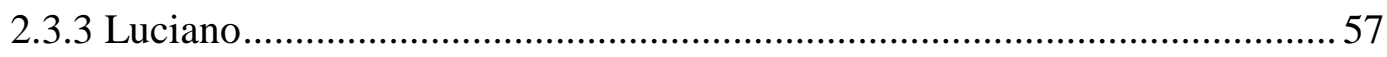

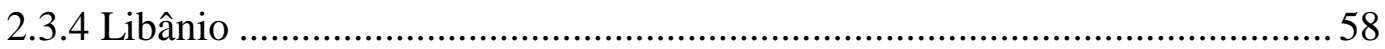

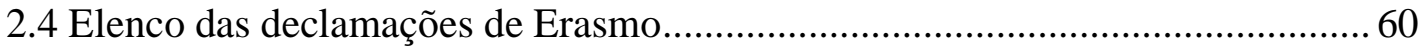

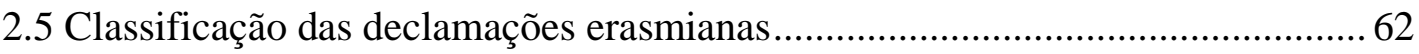

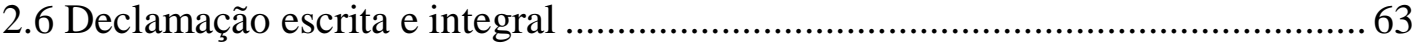

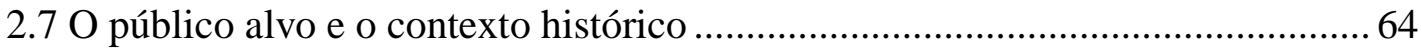

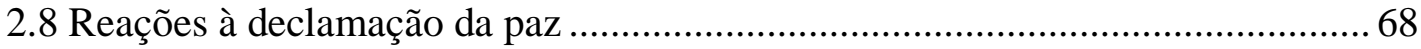

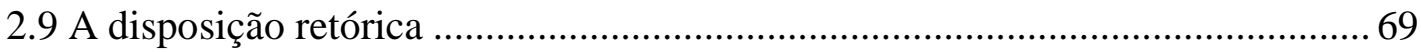

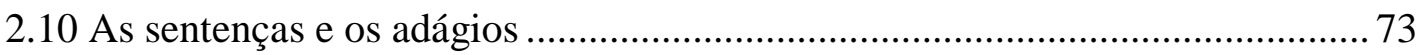

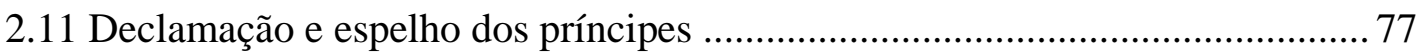

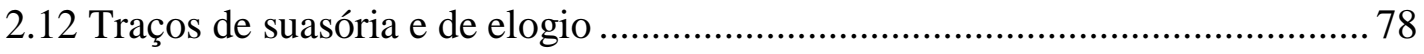

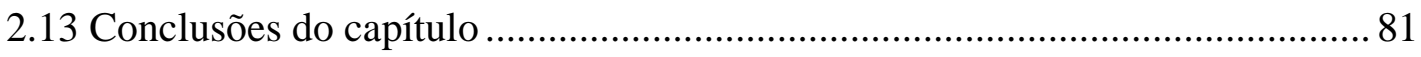

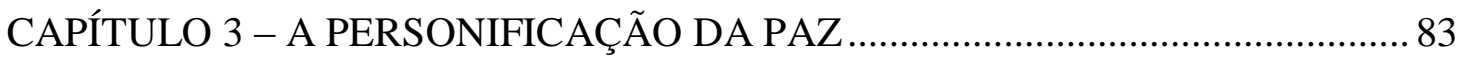

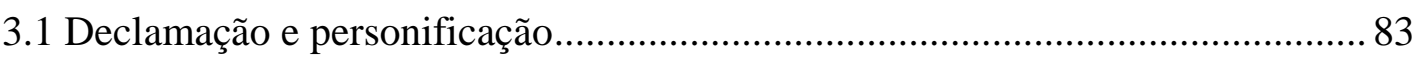

3.2 Semelhanças com as personificações bíblicas ................................................. 83

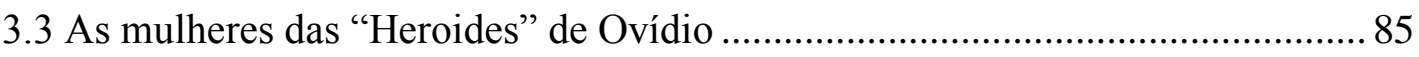




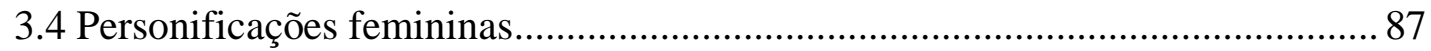

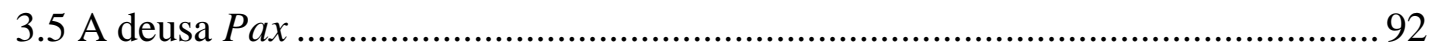

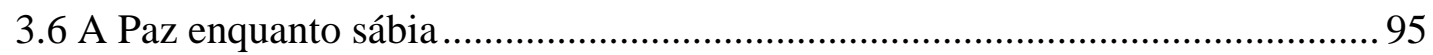

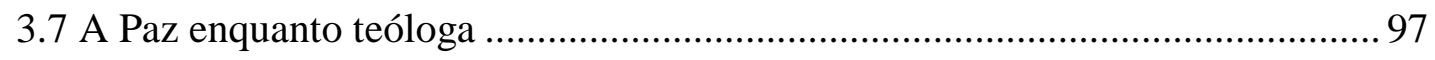

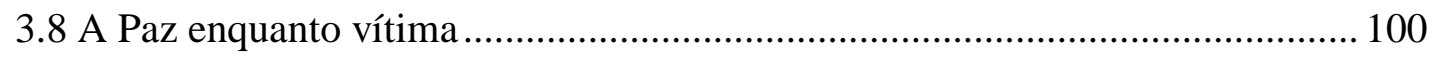

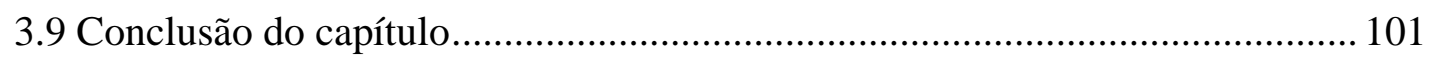

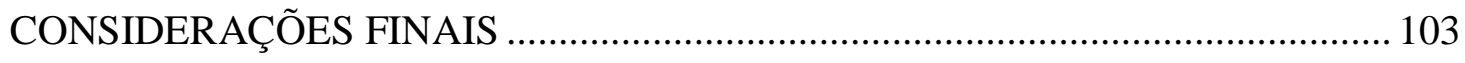

NOTA PRÉVIA AO TEXTO LATINO E À TRADUÇÃO PORTUGUESA

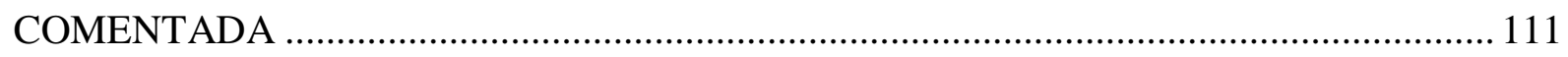

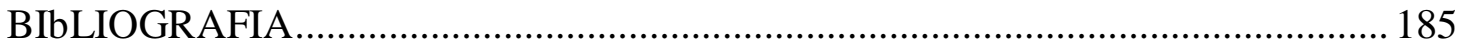

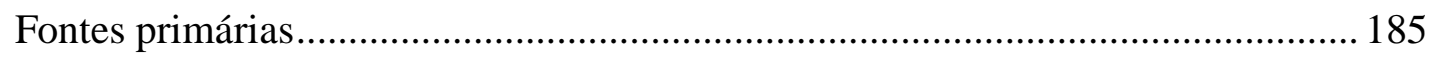

Traduções da Queixa da Paz em ordem cronológica ............................................ 185

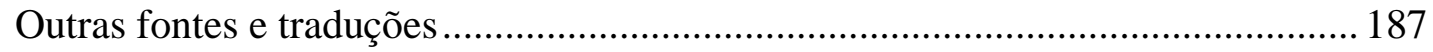

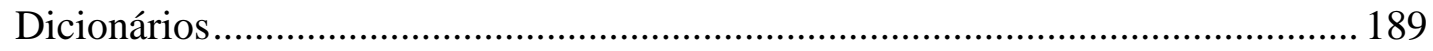

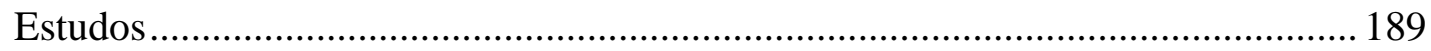





\section{INTRODUÇÃO}

É objetivo desta dissertação apresentar a primeira tradução direta do latim para o português brasileiro da declamação "Queixa da Paz" (Querela Pacis), obra de autoria do humanista holandês Erasmo de Rotterdam, ${ }^{1}$ escrita ao longo do ano de 1516 e publicada em novembro de 1517. Esta será precedida de um estudo introdutório, que procurará ressaltar o uso de recursos retóricos em defesa da paz e de crítica à guerra. Além de identificar o modo pelo qual se fez uso dos autores antigos na "Queixa da Paz", verificaremos as colaborações mais relevantes de Erasmo para a retórica, segundo a antiga tradição escrita em grego e e latim. Como objetivos específicos, o presente trabalho visa, além de propor uma nova tradução, apresentar uma introdução e notas atualizadas segundo os recentes estudos acadêmicos; assinalar a ocorrência de referências a oradores latinos, assim como daqueles declamadores do período imperial romano que escreveram em grego; identificar os elementos da retórica deliberativa erasmiana em defesa da paz do ponto de vista do gênero declamação (declamatio).

Este trabalho de pesquisa justifica-se pela contribuição da primeira tradução direta do latim para o português brasileiro da "Queixa da Paz", publicada em versão bilíngue, ou seja, com o texto latino em paralelo com a tradução, e a única precedida de um estudo introdutório específico acerca do ponto de vista do gênero a que o texto pertence. Essa tradução fornece a aos pesquisadores lusófonos um texto para o entendimento da concepção e do uso da declamação por Erasmo, que além de ser um dos mais destacados autores humanistas que “direcionaram suas obras mais importantes para a educação literária” (Mack, 1993, p. 303), escreveu quatorze obras nesse gênero, inclusive, dentre elas, algumas de suas mais lidas, traduzidas e comentadas, como é o caso do "Elogio da Loucura". Essa tradução disponibilizará aos pesquisadores lusófonos a tradução de uma das mais difundidas obras de Erasmo de Rotterdam em diversos pontos de vista, tais como: recepção dos antigos pelos autores cristãos renascentistas; a permanência dos gêneros antigos na prosa neolatina e sua atualização por meio da imitatio; recuperação da retórica antiga no século XVI; uso de

\footnotetext{
1 Sobre a referência à cidade de Erasmo (Rotterdam, Roterdão, Roterdã, Roterdam), encontrei variantes ortográficas em textos acadêmicos lusos e brasileiros. Optei pela versão "Rotterdam" com base no "Manual de Redação Oficial e Diplomática do Itamaraty" (Brasil. Ministério das Relações Exteriores. Manual de redação oficial e diplomática do Itamaraty, 2016, p. 166).
} 
recursos retóricos no gênero deliberativo; e finalmente, trata-se de um texto fundamental para a compreensão da filosofia irênica de Erasmo, ou seja, ao conjunto de argumentos filosóficos que Erasmo alinha a favor da paz, e do qual deriva a moderna concepção de paz em sua dimensão interestatal.

O texto latino por nós utilizado foi o "Querela Pacis undique gentium eictae profiligataeque" disponível na edição crítica (Desiderii Erasmi Roterodami Opera omnia/recognita et adnotatione critica instructa notisque illustrata. Amsterdam: NorthHolland, 1969-2001), coleção cujo volume com o texto em estudo foi publicado em 1977. Como fontes de conceituação da arte retórica, servimo-nos das obras dos autores latinos e gregos que escreveram sobre a retórica e sobre a declamação, especialmente aqueles que foram certamente conhecidos por Erasmo. Conforme Chomarat (1981, p. 990), devem-se considerar alguns autores que influenciaram Erasmo na redação da "Queixa da Paz", especialmente os que escreveram sobre a retórica e sobre a declamação. Especial atenção deve ser dada aos autores que além de teorizarem sobre o gênero também o praticaram. Conforme a observação de Franco Gaeta (1968, p. 13), procurar-se-á a fundamentação em "Instituição Oratória" de Quintiliano, assim como nas "Controvérsias" e "Suasorias", de Sêneca, o velho, e no "Sobre a Clemência" de Sêneca, o Jovem. Nesse grupo de autores antigos, devemos ainda acrescer Cícero, Plutarco, Libânio e Luciano. Os textos destes autores foram citados por Erasmo, que, além de tradutor, também era editor, e que teve uma contribuição significativa para a introdução dos métodos críticos na história da filologia, conforme o consenso de vários autores da área (Bentley, 1977, p. 9; Prete, 1965, p. 259; Prete, 1970, p. 18; Payne, 1974, p. 54).

Segundo evidências internas e externas, apontadas em um estudo das epístolas erasmianas realizado por Beauduin (1991, p. 35), essa obra foi escrita em Lovaina, Bélgica, entre novembro e dezembro do ano de 1516, a pedido do grande chanceler da Borgonha, João Sauvage, e dedicada ao Abade de Saint-Bertin, Antônio de Bergen. Nesse mesmo ano, Erasmo havia sido nomeado conselheiro do príncipe Carlos de Borgonha, que logo se tornaria Carlos de Espanha (Margolin, 1992, p. 909). Foi publicada em 1517 e reeditada em 1518. Como evento histórico próximo que pode ser considerado o principal motivo da redação desse manifesto em favor da paz, deve-se destacar que estava em curso a guerra da Liga de Cambrai, a qual se estendeu até os enfrentamentos das guerras da Liga Santa (1508-1516). 
Que este tenha sido de fato o motivo decisivo para que o autor humanista escrevesse essa "Queixa da Paz", prova-o a menção a tais fatos históricos em uma de suas correspondências a João Botzheim (1523). ${ }^{2}$ Da mesma forma, Erasmo alude indiretamente ao tema no final da declamação.

Partindo do pressuposto de que o próprio Erasmo afirmava na epístola a João Botzheim que a “Queixa da Paz" é uma declamação (Chomarat, 1987, p. 997), pretendemos discutir no estudo introdutório sobre as características desse gênero. Para isto, não somente

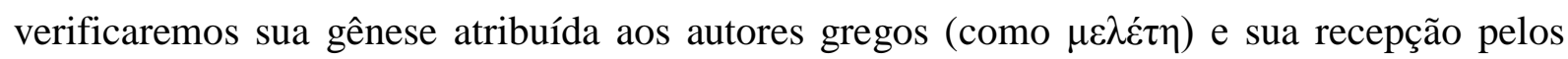
autores latinos (como declamatio), mas em que medida a declamação erasmiana enquadra-se nesse gênero antigo.

Em geral, seu formato antigo foi definido por Bonner (1949, p. 13), Wintterboton (1980, p. 24) e Schwartz (2004, p. 21) como um discurso escrito como exercício escolar acerca de uma causa fictícia, com a finalidade de treino em temas da retórica deliberativa ou judiciária. Dentre suas características, o presente estudo ressalta a personificação, que nas declamationes renascentistas, especialmente em Erasmo, foi praticada de uma forma inovadora em comparação com as antigas. Enquanto que naquelas antigas, ou seja, produzidas nos séculos I a. C a I d. C. As personagens são humanas e fictícias, o que denota certa modificação para o gênero em estudo. A novidadade das declamações renascentistas, especialmente em Erasmo, seria a inserção da fala (prosopopeia) de personagens abstratas, como a Paz, na "Queixa da Paz", e a Loucura em seu "Elogio".

Por outro lado, destaca-se a ficção como estratégia para expressar ideias de forma livre em uma sociedade que não prezava a liberdade de expressão e a caracterização com atributos sociais e psicológicos do universo feminino nessas personificações erasmianas. Tal caracterização, sem o uso de voz narrativa, como é natural na declamação, mas através do discurso direto, apresenta a paz como mulher e mãe, apelando às emoções do leitor a fim de cativá-lo para a causa irênica pretendida pelo autor. Convém, portanto, analisar a "Queixa da Paz" sob a perspectiva da recepção do gênero declamação, de um modo semelhante ao que era praticado pelos autores antigos e predicado nos manuais de retórica latina.

${ }^{2}$ Cf. Erasmo de Rotterdam. A Johann von Botzheim. in: Correspondence of Erasmus: Letters 1252 to 1355 , 1522 to 1523. Trad. James Martin Estes. Toronto: University Toronto Press, 1989, p. 319. 


\section{Estrutura do estudo introdutório}

O estudo introdutório está composto de três capítulos, os quais procuram apresentar a "Queixa da Paz" em sua relação com o gênero literário que inspirou sua forma, a declamação. Assim, o primeiro capítulo o caracteriza entre alguns autores antigos que escreveram sobre o ele ou utilizaram-se dele no período compreendido entre os séculos I a. C e I d. C. Além do recorte do período e dos autores, será dada atenção especial às referências à declamação nas obras de Cícero, na "Retórica a Herênio", nos Prefácios das "Controvérsias" de Sêneca, o Velho, e na "Instituição Oratória" de Quintiliano, que ilustram as discussões das características da declamação que presentemente consideramos.

O segundo capítulo discorre sobre a prática deste gênero por Erasmo. A discussão se inicia com uma descrição do seu uso entre os autores do Renascimento, sobretudo daqueles que podem ter influenciado o roterdamês na escrita das suas declamações. Seguir-se-á um elenco das declamações erasmianas e um estudo da questão de espécies de declamações, suas relações diretas com outros gêneros e a ocorrência de prosopopeias, a fim de estabelecermos comparações.

O terceiro capítulo trata da "Queixa da Paz" em comparação com o gênero declamação praticado e teorizado pelos autores antigos conforme se discorreu no capítulo primeiro, assim como algumas datadas do Renascimento ou de autoria do próprio Erasmo. Aqui, procuraremos ainda demonstrar como e em que medida esta obra pertence à linhagem da declamação, tal como esta era prescrita e praticada pelos autores dos séculos XV e XVI. Tais comparações visam, sobretudo, a dois pontos: primeiro, tratar a respeito do subgênero da "Queixa da Paz", ao analisar os argumentos a favor de classificá-la como do epidítico ou como do deliberativo; segundo, uma vez que os autores do Renascimento utilizavam intencionalmente os princípios da retórica antiga para a invenção de seus escritos, discutiremos a caracterização da Paz, enquanto prosopopeia abstrata e feminina, como estratégia de persuasão em conformidade com as regras de retórica antiga recebida no Renascimento. 


\section{Estudos e publicações precedentes sobre o objeto de pesquisa}

Antes de entrar no objeto proposto, convém pontuar o estado dos estudos acadêmicos acerca do gênero declamação, e, mais especificamente, da sua recepção entre os escritores humanistas. A produção de artigos acadêmicos ou dissertações nesse recorte temático não é numericamente ampla, mas tem sido enriquecida por especialistas voltados para pesquisas sobre a declamação ou os autores que a ela se dedicaram. Ao iniciarmos o cotejo das versões da "Queixa da Paz", verificamos que se encontram disponíveis para consulta on-line seis das vinte e cinco edições desta obra, datadas do século XVI. Além dessas edições latinas, foi possível encontrar uma tradução francesa do século XVI: La Complainte de la Paix. Tradution de le Chevalier de Berquin (1525). Verificou-se, ademais, que há uma edição crítica (Desiderii Erasmi Roterodami Opera omnia / recognita et adnotatione critica instructa notisque illustrata. Amsterdam: North-Holland, 1969-2001) e dezenas de traduções em inglês, francês, italiano, alemão e português, cuja lista encontra-se na bibliografia, e da qual salientamos a existência de doze edições nos últimos quinze anos em cinco vernáculos ocidentais. Deve-se dizer que muitas destas, não parecem ser traduzidas diretamente do latim. Dessa profusão de fontes e traduções, infere-se que a "Queixa da Paz" é uma obra que não somente obteve grande difusão durante o século XVI. Ainda hoje, é umas das obras de Erasmo mais difundidas equiparavelmente ao "Elogio da Loucura" e o "De Copia". O primeiro dispensa apresentação, no caso do segundo, convém lembrar que, "seguindo os modelos de Cícero e Quintiliano e tendo como principal objetivo a invenção, foi provavelmente o manual mais estudado de todo o Renascimento" (Mack, 1993, p. 305), contando com mais de cento e cinquenta edições somente na centúria de sua publicação. Esta difusão denota a relevância e a influência desse autor para a recuperação da retórica antiga em seu tempo. Muitos dos princípios retóricos consignados nesse manual são postos em prática na declamação que pretendemos analisar. Há também a edição das epístolas de Erasmo realizada sob a direção de Allen (1906) e que são úteis para o entendimento da compreensão do próprio autor acerca da sua obra, das circunstâncias históricas que inspiraram a redação do discurso da Paz e dos conceitos que põe em prática nessa declamação.

Embora muitas destas edições (Bagdat, 1924; Von Balthasar, 1945; Dolan, 1964; Philip, 1967; Gaeta, 1968; Christian, 1968; Radice, 1968; Telle, 1978; Hannermann, 1985; Van Leeuwen, 1986; Levi, 1986; Chomarat, 1991 e 1974; Margolin, 1992; Carena, 1995; 
Pinto, 1999; Cinti, 2005; Labre, 2005; Jovella, 2008; Bellacasa, 2008; Hoffmann, 2013) apresentem introduções à "Queixa da Paz" ou a outras obras de Erasmo (Sartorelli, 2013; Sánchez Salor, 2011; King e Rix, 2007), deve-se dizer que, embora estas apresentem alguns dados que não podem ser preteridos e que foram considerados no presente estudo, estes textos introdutórios estão muitas vezes limitados às regras e aos objetivos editoriais, restringindo-se a informações biográficas ou históricas, sem análises aprofundadas do texto, seu gênero ou recepção.

Além das introduções das traduções, verificou-se a existência de apenas um estudo acadêmico na área de literatura específico sobre a "Queixa da Paz" (Bagdat, 1924), assim como o artigo de Chomarat (1974) e um dos capítulos do seu livro "Grammaire et Rhétorique chez Erasme" (1981). Foi então necessário incrementar a pesquisa com artigos acadêmicos e livros publicados mais recentemente por editoras universitárias que tratam sobre temas indiretamente relacionados com o objeto de pesquisa, ou seja, sobre o autor (Erasmo de Rotterdam), sobre a obra em estudo; sobre o gênero no qual foi escrita a obra (declamação) e sobre a recepção da retórica antiga entre os humanistas. Dada a falta de estudos que tratam diretamente sobre a Queixa da Paz, não foi possível apresentar um estado da questão no sentido a que se está habituado na academia, mas apenas algumas obras que apresentam relação parcial com nosso objetivo.

Tendo diante de si estes livros ou artigos, é possível classificá-los nos seguintes grupos: (grupo 1) sobre a retórica e a declamação antiga; (grupo 2) sobre a recepção da retórica e da declamação no Renascimento; (grupo 3) sobre estas em Erasmo. Dadas as limitações temporais do mestrado, assim como a dificuldade de acesso a alguns livros não disponíveis nas bibliotecas brasileiras, os livros, capítulos de livros e artigos abaixo catalogados não esgotam a bibliografia sobre as matérias em questão, como é o caso de muitas obras de origem francesa que não foi possível acessar, mas que não são pertinentes para o presente estudo uma vez que tratam da recepção da obra de holandês em outros autores a partir do século XVI.

Ainda que nossa intenção primeira fosse atentar para a declamação latina, não era possível preterir alguns estudos sobre a grega (Russell, 2009) e sobre a caracterização da mulher nesta (Gruber, 2008), uma vez que se fazem pertinentes não somente para a consideração da romana, mas também daquela praticada por Erasmo, que as conhecia ainda 
na forma de manuscrito. Entre os estudos sobre a declamação latina, destacam-se o de Wolf (2013), Van Mal-Maeder (2007), Winterbottom (1980 e 2006), Shenk (1982), Mendelson (1994), Clarke (1996), Bonner (1949 e 1966) e Schwartz (2000 e 2004). Também se tornam pertinentes alguns estudos específicos sobre as declamações, como o de Bonner (1966) sobre Luciano; o artigo de Schwartz (2000) sobre esse gênero sob Augusto; os dois artigos de Bayley, sobre as "Declamationes maiores" e "minores" atribuídas a Quintiliano (1984 e 1989); os artigos de Clark (1957) e Dupont (1997) sobre sua prática escolar; e os estudos de Marrou (1948), de Vasconcelos (2000 e 2002), de Gibson (2004) e de Manoel (2014) sobre as progymnasmata; o estudo acerca da relação do contexto histórico com as controvérsias escrito por Mendelson (1994); o artigo com o recorte sobre as "crianças abandonadas" nas declamações (Bernstein, 2009); o artigo sobre a declamação em Sêneca (Edward, 1928; Sussman, 1972; Fairweather, 1981; Schwartz, 2004; Bloomer, 2010; Costrino, 2010); ou ainda outros autores como em Tácito (Pereira, 2013), em Quintiliano (Reali e Turazza, 2012) e em Luciano (Thompson, 1965 e 1974). Dentre este, alguns não somente foram lidos por Erasmo, mas também traduzidos por ele do grego para o latim.

Sobre a recepção da declamação no Renascimento (grupo 2), destacam-se os artigos de Kinney (1976) e Vasoli (2008) sobre a retórica humanista. Devem-se ressaltar ainda os textos sobre as declamações de Erasmo analisados por Giazzi (2008), Tunberg (1996, 2006 e 2013), os já mencionados escritos de Chomarat (1974 e 1981) e Van der Poel (1987 e 1989). Além disso, Van der Poel publicou artigos sobre a declamação em Agripa e Erasmo (Van der Poel, 1994 e 1997) e em Cardano (Vander Poel, 2005). Entre os estudos sobre as declamações de Erasmo, em particular, destaca-se a referência de Grimal (1994) sobre a declamação "Sobre a morte" de Erasmo; as introduções ao "Diálogo Ciceroniano" (Pigman, 1977, Sartorelli, 2015); ao "Elogio do Matrimônio" de Leushuis (2004) e Sowards (1958 e 1982), sobre o "Elogio da Loucura" (Sartorelli, 2013; Moya Bedoya, 1994). Sobre a influência de Valla em Erasmo há o artigo de Bentley (1977), assim como os estudos de Schwahn (1928) e Ginzburg (2004) sobre a declamação "Doação de Constantino". Temos ainda os estudos de Fox (1983), Baumann (1985) e Corral (2012) sobre o "Tiranicida" de More, os de Logan (2003) e Miller (1994) sobre a "Utopia"; e, por fim, sobre o "Elogio de Nero" de Cardano, o estudo de Biffino (2002). 
Sobre a recepção da retórica antiga em Erasmo (grupo 3), verificamos a existência de capítulos de livros e artigos de Murphy, (1974, 1983, 2005 e 2012), Bataillon (1977 e 1982), Margolin (1973, 1977, 1992, 1987, 1993, 1995, 1997 e 1998), Chomarat (1974 e 1981), Pigman (1980 e 1990), Green e Murphy (2006), Mack (1993, 1996 e 2011), Sartorelli (2001, 2009, 2012, 2013 e 2015), Rummel (1985, 1990, 1996, 1998, 1999 e 2000), Weiland (1988), Pinto (2006) e Logan (1994). Há alguns estudos sobre a recepção da retórica antiga no Renascimento que se referem marginalmente sobre Erasmo, como o de Burke (2003) e os artigos de Kinneyy (2004), Gómez Cervantes (2007), Alexandre Júnior (2008), Hernández Guerrero e García Tejera (1992) e Gianotti (2008). Ainda nesse grupo, destaca-se o artigo sobre "declamação e retórica" de Gunderson (2009). Tendo como recorte a obra de Erasmo, temos Sloane (1991 e 2004) e Pinto (2006). Há ainda sobre a sátira em Erasmo feita por Story (2012). Kennedy (1980), Hoffmann (1994) e Boyle (2004) também apresentam artigos sobre a relação da filologia e da retórica erasmiana com a teologia e a filologia bíblica. Ainda no recorte do Renascimento, destaca-se o estudo filosófico sobre a paz feito por Cailes (2012), no qual compara as teorias de Erasmo e Machiavel e os estudos filosóficos acerca do pacifismo de Erasmo realizados por Meulen (1990), Hoffmann (2000), Kinsella e Carr (2007), Martín (2007), Dungen (2008) e Christi (2009). A respeito de outras questões, filosóficas ou literárias, podemos citar as dissertações ou teses defendidas na própria Universidade de São Paulo: a de Salum (2009), a de Nassaro (2010) e a de Rodrigues (2012).

Embora não seja o foco principal da pesquisa, tivemos o cuidado de consultar algumas biografias. Entre estas, acessamos duas por Bainton (1969) e Faludy (1970). Minnich e Meissner (1978), Boeft (1989), Bietenholz (1985 e 2009) e Vredeveld (1993) escrevem textos de índole histórico-biográfica. Ménager (2000) redigiu um artigo acerca da posição política neutra de Erasmo face à política francesa e espanhola. Merece especial destaque o trabalho biográfico de Beauduin (1991) com base na epistolografia erasmiana. Há também estudos históricos sobre a influência erasmiana no século XVI (Rowland, 1987).

No tocante à recepção que os escritos de Erasmo obtiveram, sem pretender esgotar o universo desse gênero de pesquisa e que não se configura como essencial para na pesquisa, como é o caso da ampla produção francesa, tivemos acesso, ao artigo sobre sua influência em João Fletcher, escrito por Waith (1951); em João Bodin, conforme artigo de Remer (1994); em Bartolomeu de las Casas, segundo Torres (1993); na Alemanha do século XVI, por Tracy 
(1969); na literatura francesa, em artigo de Phillips (1971); no século XIX, por Mansfiel (1968), e sobre a recepção da declamação romana no século XX, por Gunderson (2003).

Destacam-se alguns estudos temáticos, como o texto de Whers (2004) sobre a ética erasmiana; sobre a recepção do "Adversus Jovianum” em Erasmo, escrito por Pabel (2002); sobre a influência de Jerônimo no holandês, em artigo de Sloane (2004); e sobre a influência da "Arte Poética" de Horácio sobre os "Adágios" publicado por Magnien (2012). Como analisaremos a caracterização da paz enquanto personagem feminina, é necessário considerar o livro de Rummel (1996) sobre a mulher em Erasmo; e os artigos sobre a educação feminina publicado por Soward (1982), por Cousins (2004) e por Leushuis (2004). Sobre a ficção nas declamações, temos o estudo de van Mal-Maeder (2007) que inclusive foi comentada em resenha por Bloomer (2009). Entre estes trabalhos, deve-se levar em consideração a questão sobre a oposição dos humanistas aos escolásticos (Bejczy, 2001; Rummel, 1998).

Esta pesquisa verificou, portanto, com a exceção da dissertação de Bagdat (1924) e o artigo de Chomarat (1974), o qual tratou especificamente sobre a "Queixa da Paz", do ponto de vista da área de Letras, a inexistência de artigo acadêmico ou livro específico sobre o tema em questão, ou seja, sobre a recepção do gênero declamação. Encontramos apenas seu tratamento de modo sucinto em Chomarat (1981) e Van der Poel (1989). Por outro lado, verificou-se a necessidade e a relevância acadêmica do estudo das declamações de Erasmo e de considerações mais específicas sobre a "Queixa da Paz" do ponto de vista da recepção dos antigos. Como vários autores mencionam este gênero e a própria declamação como exemplo, deve-se considerar que, devido ao caráter marginal de muitos comentários, sem a especificidade de uma referência direta à declamação em comento, ou ao tratar do pacifismo erasmiano, sem muitas vezes levar em consideração o gênero literário da obra, torna-se pertinente um texto específico sobre o gênero literário, sua personificação feminina da paz, sob o enfoque da recepção dos autores antigos, a qual ainda é inédita no mundo acadêmico. Ademais, com exceção do capítulo de Chomarat (1981), e apesar da importância da retórica antiga para os autores do Renascimento, verificamos a inexistência de textos acadêmicos específicos sobre a retórica na "Queixa da Paz", motivo pelo qual se verifica mais um ponto de novidade no presente estudo. 


\section{CAPÍTULO 1 - O GÊNERO DECLAMAÇÃO E SUA RECEPÇÃO NO RENASCIMENTO}

O presente capítulo trata da definição conceitual e das diferenças essenciais e terminológicas do gênero declamação (em latim, declamatio, em grego, $\mu \varepsilon \lambda \varepsilon \dot{\tau} \eta$ ) entre alguns autores antigos gregos e latinos, especialmente nos tempos finais da República e do início do Império. Entre esses autores antigos, daremos atenção especial à forma como o assunto aparece nas obras de Cícero; na passagem pertinente da "Retórica a Herênio"; em alguns prefácios das "Controvérsias" de Sêneca, o Velho; e, por fim, em Quintiliano, em razão da influência da "Instituição Oratória" sobre os humanistas a partir da redescoberta de um de seus manuscritos na íntegra no início do século XV. Após uma descrição do uso da declamação entre as edições dos autores antigos que escreveram declamações ou teorias sobre a declamação e foram editados ou traduzidos no Renascimento, nosso enfoque recairá especialmente sobre aqueles autores humanistas que precederam Erasmo na recuperação do gênero.

\subsection{Origem grega}

\subsubsection{Definição}

Partindo do pressuposto de que o próprio Erasmo, em carta a João Botzheim datada de 1523, classificou a Queixa da Paz como uma declamação, e de que há consenso entre estudiosos, como Chomarat (1981, p. 997), que confirmam esta classificação, é oportuno considerar o que vem a ser exatamente uma declamação segundo a conceituação dos autores antigos imitados pelos humanistas. Em conferência ainda não publicada, Sartorelli assim define a declamação in genere:

$\mathrm{Na}$ Antiguidade, as declamationes eram discursos escritos como exercício escolar, acerca de uma causa fictícia, apenas para aquecimento ou treino nos cursos de oratória. Tratava-se, portanto, de preparação para a ocasião em que a fala de fato se faria necessária (o tribunal, a assembleia) e uma demonstração de habilidade. O exercitar-se era o essencial, para manter-se 'em forma' para um público cujos ouvidos estavam acostumados ao mais alto nível de eloquência, e que não deixaria passar um deslize por parte daquele que discursava (Sartorelli, 2013, reprodução de conferência). 
Deve-se recordar que alguns poucos exercícios similares à declamação (a $\mu \varepsilon \lambda \varepsilon \dot{\varepsilon} \tau \eta)$, ainda que tais discursos sejam duvidosos em relação à sua finalidade escolar, teriam sido praticados pelos sofistas, entre os quais podem-se citar o Elogio a Helena ou a Defesa de Palemedes, cuja autoria foi atribuída a Górgias e que são datados do século IV a. C., ou ainda as Tetralogias de Antifonte (Winterbottom, 2006, p. 76; Costrino, 2010, p. 12; Kennedy, 1980, p. 28). Conservaram-se ainda alguns papiros de declamações gregas datadas do século III a. C., consideradas as mais antigas declamações conservadas (Russel, 2009, p. 6).

Nesse particular, Kennedy (1980, p. 103) ressaltou a importância do manual sobre declamações do gênero epidítico. Este é composto de oito capítulos preservados entre as obras de Dionísio de Halicarnaso, mas escrito por um autor anônimo do terceiro século, traz orientações retóricas para a composição de Elogios para os festivais, casamentos, aniversários e exortações para os jogos olímpicos. Entretanto, "os mais extensos tratados com a forma epidítica da declamação se concentram em dois trabalhos atribuídos a Menandro de Laodiceia, um rétor do terceiro século" (Kennedy, 1980, p. 103).

Apesar da heterogeneidade dos corpora declamatórios gregos, aquelas declamações têm em comum o fato de simularem a defesa de uma causa fictícia baseada em acontecimentos históricos ou mitológicos. Contudo, no que se refere à precisão das datas, dos nomes e a situação dos casos declamados não era de primordial preocupação, permitindo-se ali imprecisões, pois sua principal finalidade, era, como dissemos, a prática da oratória e a persuasão dos ouvintes (Wolf, 2013, p. 270). Gibson (2004, p. 105-106), todavia, demonstra que, ao menos no manual de Hélio Teão, havia certa preocupação com a historicidade das declamações (Winterbottom, 1980: v), pois o discurso deveria ser adequado como um "exercício histórico", harmônico com a caracterização das personagens e com os dados narrativos (Gibson, 2004, p. 105-106).

Usando as tradicionais categorias dos três gêneros, também presentes em Aristóteles (Retórica. 1.4), algumas dessas declamações foram classificadas como judiciais, uma vez que tinham como meta defender ou atacar alguém no ambiente forense, procurando influenciar na elaboração de uma sentença de culpa ou absolvição (Fairwethear, 1981, p. 545). Outras, por outro lado, poderiam pertencer aos gêneros epidítico e deliberativo, já que também versavam sobre temas histórico-mitológicos, seja para aconselhar ou desaconselhar em uma deliberação, seja para elogiar ou vituperar (Gibson, 2004, p. 103). Segundo o estudo de Russell (2009, p. 
4), como exemplos de declamações gregas do gênero deliberativo (suasória), podem-se mencionar as de Polemon de Laodiceia e Adriano de Tiro. Para ele (2009, p. 6), as declamações de Corício de Gaza teriam sido "as melhores desses autores", pois apresentam "um estilo virtuoso, capaz de escrever com elegância e com um ático clássico em total observância das cláusulas do seu próprio tempo".

Alguns pontos gerais na declamação clássica grega merecem ser considerados em detalhes em razão da relevância do uso da personificação no discurso irênico erasmiano. No tocante à caracterização das personagens envolvidas nas declamações gregas, Russell (2009, p. 87-90) afirma que os elementos do êthos retórico estavam presentes nas declamações, pois estas levavam em conta a adequação da imagem de si mesmo, as particularidades da audiência e a situação psicológica e social dos oponentes. O autor (Ibid., p. 92-93) apresenta a declamação 33 de Libânio como um dos exemplos de caracterização completa de uma personagem feminina através da narração (katastasis) minuciosa dos elementos da vida doméstica. Além disso, Russell (Ibid., p. 83) percebeu uma relação estreita de alguns elementos da declamação grega com os da comédia, tendo ainda notado (Ibid., p. 102) que as declamações gregas também tinham um epílogo harmonioso com o tema presente nos primeiros parágrafos, demonstrando que esta deveria ser uma das suas virtudes. Por fim, convém destacar, sempre segundo Russel (Ibid., p. 4-5), que algumas delas eram realizadas tanto a favor de somente um dos lados da questão quanto a favor dos dois lados sucessivamente, como se verificou na "Vida dos sofistas" de Filóstrato.

É preciso considerar que os principais corpora de declamações gregas foram escritos no período histórico em que Roma dominava politicamente a parte oriental do Mediterrâneo, onde predominava o grego como língua franca, por isso algumas coleções não foram escritas em latim. Não sem razão, no parecer de Kennedy (1980, p. 103), “a declamação foi o maior fenômeno retórico do Império Romano escrito em latim e grego". Para Bloomer (2010, p. 297), “a declamação é o primeiro grande movimento literário do Império Romano”. Embora existam outros gêneros literários cuja difusão também tenha sido comparável, ou talvez superior em sofisticação à declamação, deve-se, porém, destacar que a prática declamatória não se limitava aos célebres círculos eruditos, mas também estava presente no círculo escolar e filosófico. 


\subsubsection{Principais autores e escritos em grego}

Entre os principais nomes da declamação grega, sobretudo na prática da suasória e das controvérsias históricas, devem-se destacar Plutarco, Aristides, Luciano, Libânio e Corício. Historicamente, tais autores se concentram em período posterior ao que é correntemente denominado como Segunda Sofística, cuja delimitação, apesar de controversa, é geralmente compreendida entre os séculos I e IV d. C.. Corício estaria situado no período da Terceira Sofística (Silva, 2015).

Plutarco escreveu apenas seis obras morais que são especificamente identificadas como declamações, entre as quais se destacam: "Se os atenienses são melhores nas armas do que nas letras" e o discurso "Sobre a fortuna e a virtude de Alexandre", no qual consta um elogio ao monarca (Boulet, 2013, p. 61).

Entre os discursos de Hélio Aristides, destacam-se aqueles com temas históricos propostos aos estudantes, também conhecidos como declamações históricas. O mais célebre, o "Leuctrian”, apresenta as controvérsias de apoio e neutralidade em relação a Tebas, Atenas e Esparta (Russell, 1983, p. 4).

Quanto a Luciano de Samosata (125-181 d. C.), temos nomeadamente os discursos a favor e contra a aceitação do touro Phalaris em Delfos; e o discurso cômico "Tribunal das vogais" em que o Sigma cobra o Tau pelo roubo de todas as palavras soletradas com duplo Tau.

Entre os mais profícuos produtores de declamações, Libânio de Antioquia (314-394 d. C.) escreveu cinquenta e uma declamações ainda conservadas, das quais poucas são questionadas quanto à autenticidade. Entre as históricas destacam-se a "Apologia de Sócrates" e alguns plasmata, que são casos fictícios, entre os quais alguns explicitamente cômicos (Russel, 1983, p. 4).

Por fim, devemos mencionar Corício de Gaza (primeira metade do século VI), autor que já pertence ao período denominado como Terceira Sofística. Escreveu doze discursos que tratam desde temas e locais comuns imitados de textos gregos antigos como Homero e Heródoto, até elogios ao Bispo Marciano e a apologia dos mimos, um gênero popular de 
Gaza. Digno de nota é o discurso no qual simula a tentativa de Pátroclo em persuadir Aquiles a retornar ao campo de batalha após o ultraje de Agamêmnon (Silva, 2015, p. 75).

Dada a relevância da caracterização de personificações femininas para o presente estudo, convém destacar desde já que, no tocante ao estudo destas nas declamações gregas, os papéis representados pela mulher eram em menor número em comparação com o de personagens masculinas (Gruber, 2008, p. 138-140). Estas poderiam ser a filha, a mãe, a madrasta, a mulher, a esposa, a concubina e a meretriz. Todavia, não costumavam receber as variações de caráter atribuídas ao homem, como ser rico, pobre, velho, filósofo, entre outros. Segundo Gruber (ibid., p. 139), as mulheres eram caracterizadas como "céticas, pródigas, extravagantes, invejosas, orgulhosas, incômodas e más”. Para exemplificar em qual tipo de declamações as personificações femininas costumavam ocorrer, Gruber (ibid., p. 140), considerou que, nas declamações de Menandro, as mulheres estavam envolvidas principalmente em casos de adultério (41\% de 89 declamações) e rapto (13\%). Disto se pode concluir que as mulheres ocupavam um papel secundário nas declamações gregas, não somente por serem caracterizadas com menor variedade e especificidade quando comparadas às masculinas, mas também por estarem na maioria das vezes em posições sociais consideradas inferiores, como é o caso de uma mulher indefesa sujeita ao rapto, ou ainda, de modo a angaria a antipatia dos leitores, como é o caso da adúltera.

\subsection{A prática latina}

Com efeito, Winterbottom (1980, p. 10) observa que as personagens habituais presentes nas declamações latinas também parecem ser inspiradas no ambiente cultural helênico ou, ao menos, recebidas do contato com as declamações gregas, talvez pela leitura das próprias declamações ou através dos manuais de retórica de origem grega que circulavam em Roma:

...são personagens características, com as quais simpatizamos (jovens violadas, filhos deserdados, tiranicidas) ou com as quais não se simpatiza (piratas, pais severos, tiranos) [...] Destarte, as raízes desse mundo são helênicas, e remontam pelo menos até o quarto século antes de Cristo (Winterbottom, 1980, p. 10). 
Incontestavelmente, trata-se de mais um gênero literário originado entre os gregos e transmitido aos autores latinos, os quais o modificaram segundo as circunstâncias do seu tempo:

o uso de exercícios retóricos sobre temas judiciais e deliberativos havia sido praticado por rétores gregos e por seus discípulos séculos antes do tempo de Sêneca, o velho, e haviam entrado no programa escolar latino durante a infância de Cícero, pelo menos (Fairweather, 1981, p. 543-4).

Ao se referir a Crasso e Antônio, mencionados no "Sobre o Orador", Vasconcellos (2000, p. 180) afirma: “a educação nas escolas dos rétores, de tradição sofística, consistia, sobretudo, em ensinar ao aluno de oratória os preceitos técnicos sobre o dizer por meio de manuais chamados de "Arte Retórica", ensino demasiadamente formal e pouco eficiente na visão dos dois oradores do diálogo". O objetivo primário da declamação latina era, sobretudo, o exercício da eloquência, o tirocínio do discurso persuasivo (Kennedy, 1980, p. 108), não obstante sua prática fosse mais abrangente.

Com efeito, como indicamos acima, os exercícios declamatórios não eram apenas parte integrante do programa das escolas retóricas, situados geralmente após as progymnásmata, mas também eram praticados nas escolas filosóficas, por meio do que passaram a ser chamados de "thesis" (Winterbottom, 2006, p. 94; Kennedy, 1980, p. 37). Uma vez que a educação retórica era realizada com o intuito de obter crescimento gradual da dificuldade ou da complexidade do discurso (Costrino, 2010, p. 13), as teses de temática filosófica estavam localizadas sempre ao final dos manuais de retórica, como os de Hélio Teão, Hermógenes, Nicolau e Aftônio (Kennedy, 1994, p. 16), indicando que deveriam ser os exercícios mais complexos. Segundo Marrou (1975, p. 439), "uma vez concluída a longa série de exercícios preparatórios, o aluno era solicitado a redigir discursos fictícios, sobre um tema dado pelo mestre e segundo as prescrições e conselhos deste".

Tácito expressa a opinião de que as controuersiae, ou seja, as declamações do gênero judicial eram mais difíceis ou complexas do que as do gênero deliberativo:

Duas espécies de matérias são tratadas entre os rétores: as suasórias e as controvérsias. Dessas, delegam-se as suasórias aos meninos, já que são claramente mais fáceis e menos exigentes quanto ao conhecimento; as controvérsias são designadas para os mais maduros (Tácito. Diálogo dos oradores. 35$)$. 
Também Quintiliano apresenta sua opinião a respeito do grau de dificuldade entre os exercícios escolares de retórica, apresentando a prosopopeia, um exercício retórico anterior à declamação presente nos manuais de retórica e componente significativo da própria declamação, como um dos exercícios mais complexos:

as prosopopeias me parecem de longe as mais difíceis, pois nestas, a todo trabalho da suasória, acrescenta-se ainda a dificuldade da personagem; pois a mesma coisa deve ser aconselhada por César de um modo, por Cícero, de outro, por Catão, de outro (Inst. Orat., III, 8, 49).

Pode-se dizer que a dificuldade inerente da prática da suasória, entendida como uma espécie de declamação deliberativa, a que se refere Quintiliano reside justamente na configuração do êthos retórico apropriado para as personagens contidas no discurso e na formulação deste de modo convincente. Deveria, ademais, ser adequado, segundo o decorum exigido pela plateia que o assiste. Mas, em razão do conhecimento profundo das particularidades dos preceitos que as controvérsias envolviam, somados à aplicação da caracterização do êthos, o gênero judicial deveria ser o mais complexo. Pode-se então concluir que as declamações se configuravam como o último estágio da formação retórica de um cidadão romano. Eram esta os exercícios das suasoriae e, por fim, das controuersiae, ou vice-versa.

Ademais, deve-se dizer que, uma vez que a precisão histórica das datas, nomes e situação dos casos declamados não era de primordial preocupação, permitindo-se imprecisões (Wolf, 2013, p. 270), pode-se dizer que o principal virtuosismo do declamador residia na capacidade de adequar os diversos elementos da declamação, como o tema, com o caráter (ethos) da assembleia e das personagens fictícias envolvidas, pois o foco da prática declamatória era o exercício da eloquência, segundo os ditames dos manuais de retórica.

\subsection{As fontes latinas}

Diversos autores latinos trataram da declamação ou dos declamadores, subdividos genericamente em dois grupos: aqueles do período republicano, como Cícero, e aqueles do período imperial, como, Ovídio (Arte amatória), Juvenal (Sátira, 10, 165-169), Tácito (Diálogo sobre os oradores, 35), Calpurnio Flaco (Declamações), Suetônio (Sobre os rétores e Sobre os gramáticos e os rétores), Sêneca e Quintiliano. Em Ovídio (Arte amatória, 1, 465469), por exemplo, declamare ocorre com o sentido de falar com alguém em tom 
declamatório. O discurso do amante terá a eloquência persuasiva que convence o povo (nas assembleias), o juiz (nos tribunais) e os senadores (no senado). Mas essa eloquência não deve trair afetação, como mero artifício. Ovídio prega aqui a retórica cuja arte se esconde (lateant uires). $\mathrm{O}$ amante não deve parecer estar fazendo um discurso para a amada.

Entretanto, a análise das ocorrências do radical do substantivo declamatio ou do verbo declamare denota que algumas obras contêm maior número e relevância para o estudo da evolução histórica da declamação latina enquanto gênero. É justamente a consideração do seu conteúdo e do seu contexto histórico que sugerem a hipótese de que a declamação do tempo de Cícero não era idêntica a de Quintiliano e Sêneca, o Velho.

\subsubsection{Discussão terminológica}

A terminologia com a qual se denominavam os exercícios declamatórios não é unívoca entre os escritores que trataram de exercícios idênticos ou equiparáveis à declamação na literatura latina entre o século I a. C. e o século I d. C. Mendelson (1994, p. 96) discorre sobre um desses problemas terminológicos:

No tempo de Cícero, a declamação forense, ou caso legal, era conhecida simplesmente como causa, enquanto que posteriormente, já sob o Imperium, passou a ser conhecida como scholastica ou tema-escolar, a fim de indicar o modo por assim dizer restrito nos quais surgiam tais discursos artificiais.

Schwartz (2004, p. 65-66) sintetiza esta controvérsia:

No que diz respeito ao período pré-ciceroniano, cuja característica, segundo Sêneca, eram os exercícios que recebem o nome grego de thesis (tese), o material de que dispomos para nos referir a ele é bem escasso, e, portanto, torna-se difícil chegar a conclusões definitivas. Quintiliano define as theseis ou quaestiones infinitae (questões indefinidas) em oposição às causae (causas) ou quaestiones finitae (questões definidas), próprias do âmbito judicial. As questões indefinidas eram discussões dialéticas, em que os participantes defendiam uma ou outra das posições em conflito (in utramque partem) sem referência a pessoas, tempos, lugares e outras circunstâncias (cf. Quint. III. 55). Tratava-se de temas gerais de natureza abstrata, especulativa ou filosófica. Tais exercícios, desenvolvidos com frequência nas escolas dos filósofos, eram adequados à elaboração de loci communes, que também eram utilizados na oratória forense, na declamação e até em gêneros poéticos como a sátira. Quintiliano afirma que a questão indefinida é mais ampla que a causa, que é derivada dela. Assim, a questão indefinida "deve o homem casar?" (an uxor ducenda) é logicamente prévia à questão definida "deve Catão casar" (an Catoni ducenda) (cf. Quint. III, 5 8). Há na definição de Quintiliano, portanto, uma antecedência lógica da tese a respeito da causa, mas nada obriga a pensar que tal deva ter sido a ordem histórica em que sucederam essas classes de 
exercícios. Ao contrário: há evidências de que exercícios de tipo judicial devem ter existido bem antes da época de Cícero. Talvez o problema seja sobretudo terminológico. Com efeito, é possível que Sêneca, ao falar em "teses", estivesse pensando em outros exercícios, diferentes dos praticados em escolas de filosofia.

No tocante à comparação das declamações latinas supérstites que haviam sido realizadas ao longo dos séculos I a. C. e I d. C. com os três gêneros de discurso presentes na tradição retórica greco-romana, pode-se dizer que tratavam basicamente de dois tipos de causae: deliberativa (suasoria) ou jurídica (controuersia) (Mendelson, 1994, p. 93). Quanto ao epidítico, ao menos em Sêneca, o Velho, não se encontram exemplos de declamações realizadas com predominância deste gênero. Como veremos, Quintiliano admitirá o uso do demonstrativo ou laudativo, entendido como tendo por objetivo principal o elogio ou a vituperação, como um recurso argumentativo nas declamações deliberativas ou judiciais.

\subsubsection{O contexto republicano e o imperial}

Ao comparar a prática da declamação no final da república e no início do Império, identificou-se que este gênero sofreu algumas alterações no tocante à terminologia e à forma. Ela havia deixado de ser um mero exercício das escolas de retórica, ou um termo aplicado à prática privada de um exercício oratório, para tornar-se, nos primeiros anos de Augusto, uma performance pública atraente em todas as classes sociais, inclusive nas mais elevadas.

A partir de Augusto, as salas de declamação constituem um espaço que reúne oradores reconhecidos assim como personalidades da vida pública (Contr. II, 4,12-13). Convém distinguir aqui entre a declamação como prática escolar dos jovens na aula do rétor e a declamação como espetáculo público. Com efeito, nas próprias escolas de declamação se realizavam periodicamente exibições públicas das declamações já preparadas por alunos e o rétor. Não era raro que nestas ocasiões participassem ativamente convidados alheios à escola (Contr. III, praef 16; Contr. X, praef.). Desse modo, a declamação começa progressivamente a se tornar independente da finalidade de preparar para a oratória, e se converte em um fim em si mesmo (Schwartz, 2000, p. 275).

Esta fase antecedeu o declínio, por assim dizer, do prestígio desse gênero na virada do I ao II século d. C, conforme as críticas de Tácito, que identificava poucos "autênticos oradores" (Diálogo sobre os oradores, 14, 4). Mas essa crítica pode ser relativizada, se considerarmos a popularidade da declamação na Roma Imperial, pois, embora fosse uma arte nascida na escola, Suetônio (Vida de Antônio, 84; Vida de Nero, 10) atesta sua presença e exercício inclusive por imperadores. Por outro lado, durante o I século a. C., embora Pisão e 
Pompeu tivessem se exercitado na declamação (Cícero. Brutus. 309-310), seu status não era comparável ao da oratória, uma vez que, ao contrário do que se daria um século mais tarde, a declamação, no tempo de Cícero, era contestada por aristocratas como Messala ou Pólio, que a assemelhavam às práticas do tatro cômico desprezadas pela alta sociedade romana (Conte, 1999, p. 405). Destarte, identifica-se então uma ascensão da declamação pública, que teria chegado a um apogeu de prestígio nos primeiros decênios do século I d. C., não somente pelo próprio desenvolvimento do gênero, mas pela "decadência" da oratória, após seu afastamento dos padrões ciceronianos (Schwartz, 2004, p. 2). A teoria segundo a qual o auge da oratória se refletiu na ação e nos escritos de Cícero, sendo este o padrão adequado para a prática declamatória, é encontrada nas "Declamações" de Sêneca o Velho e no "Diálogo" de Tácito. A declamação seria por assim dizer a herdeira e a substituta da oratória, um gênero cujo sentido original só poderia ser vivido e praticado na República devido à falta de liberdade de expressão durante o período imperial.

Segundo Edward (1928: p. xvi-xvii), essa ascensão teve origem na transformação do sistema político romano:

Como é que aquilo que fora primeiramente um mero exercício das escolas de retórica, ou um termo aplicado à prática privada de um orador distinto, tornouse, nos primeiros anos do reinado de Augusto, uma performance pública e atraente, uma coisa praticada por si mesma, e, de certo modo, algo pelo qual todas as classes sociais se animavam? O motivo deve ser encontrado na mudança de condições políticas. A república estava extinta desde Filipos; uma vez estabelecido finalmente o poder de Augusto no Ácio, o príncipe concentrou todo o poder em suas próprias mãos: as assembleias do povo eram então desorganizadas ou de relevância política insignificante, as deliberações do senado perderam significado e efetividade; suas decisões poderiam ser revogadas a qualquer momento pela intervenção individual do Imperador. A oratória livre sobre temas relevantes, tais como aqueles que inspiraram a eloquência ciceroniana, já não podia ser ouvida. Pleitos autênticos, em que a decisão poderia ser desenvolvida por um advogado, estavam confinados às cortes centuriais e a causas não se prestavam à oratória.

A mudança do regime republicano para o imperial é comparável à transformação gradual da declamação e da sua relação com a oratória. Um dos reflexos dessa interferência do sistema político sobre a oratória dá-se, justamente, segundo Schwartz (2004, p. 2), na "redução significativa do terreno para o desenvolvimento do gênero deliberativo, uma vez que, sob o principado, o senado perde sua independência efetiva, e, junto com ela, restringemse consideravelmente as possibilidades tradicionais do discurso oratório". 
Não sem razão, a declamação tinha por modelo supremo de eloquência a própria oratória, mais especificamente a ciceroniana (Sêneca. Contr. I praef. 6) e que deveria ser imitado. Quintiliano, por exemplo, além de tratar das declamações em sua "Instituição Oratória”, cita ou menciona Cícero 362 vezes. Tal padrão de imitação persistiria ao longo dos séculos entre os rétores latinos, desde o século I d. C., com Quintiliano, até a polêmica do Ciceronianismo durante o século XVI.

Quintiliano almejava uma declamação que preparasse os estudantes para as reais necessidades e desafios do fórum e da tribuna, e, por isso, rejeitava a abordagem de temas mitológicos (Vasconcelos, 2004, p. 214). Para ele, a declamação era o "mais útil de todos os exercícios oratórios" (Instituição Oratória, II, 10, 1-2). Assim, esta não era apenas um treino para jovens aprendizes da eloquência, pois,

seria um erro julgar que, na Antiguidade, a declamação estava restrita às escolas de retórica. Os adultos, inclusive os homens de ação já célebres, mas afastados provisoriamente da vida política ou dos tribunais, se exercitavam com as declamações, a fim de não perderem o hábito da eloquência. Em 46 a. C, quando César era ditador, Cícero lecionava oratória a Hírcio e a Dolabella (Kennedy, 1980, p. 37).

A declamação antiga tinha, portanto, um público alvo análogo àquele, humanista, que surgirá depois. De fato, a importância da oratória, e, por consequência, das teorias retóricas, na vida romana é determinante. Política, jurisprudência - e inclusive o comando militar dependiam do modo pelo qual os dirigentes articulavam a palavra. O homem político era justamente aquele capaz de comunicar-se com o público ao qual cabia tomar decisões, seja no contexto judicial, seja no contexto deliberativo. É por essa razão que o público-alvo do declamador era a classe dominante, seja a parte que ainda estava em formação, no contexto escolar, seja aquela já "formada", que se exercitava ou se deleitava com o exercício em círculos de maior intimidade. Se a declamação latina visava os magistrados no primeiro caso, ou se, no segundo caso, simulava o senado no regime republicano ou no regime imperial, o discurso visava justamente às pessoas que deveriam decidir pela deliberação política. Sobre os destinatários da declamação romana, afirma Bernstein (2009, p. 332):

Os produtores e consumidores da declamação romana eram membros da alta classe romana, do imperador, cuja presença é mencionada por Sêneca (Contr. II.4.12-13), aos estudantes que poderiam ter usado essa literatura como material pedagógico. 


\subsection{A declamação segundo os autores latinos}

\subsubsection{A Retórica a Herênio}

Há três referências ao vocábulo declamatio na "Retórica a Herênio" (III, 20). Estas são as mais antigas na literatura latina, pois esta obra teria sido escrita por um autor desconhecido na primeira metade do século I a. C. (Caplan,1954: XVII). ${ }^{3}$ Para Bonner (1949, p. 20), existe

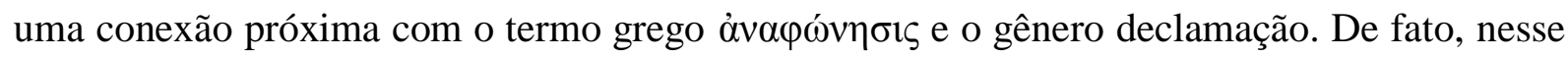
escrito, por muito tempo equivocadamente atribuído a Cícero, mas cuja paternidade ciceroniana já era posta em dúvida durante o Renascimento, apresenta-se o termo declamação como um verdadeiro exercício oral, justamente por tratar da pronuntiatio, ou seja, da forma da locução adequada a persuadir e a agradar a audiência, especialmente ao abordar os pontos da firmeza (firmitudo) e da suavidade (mollitudo) da voz. Caplan (ibid.: xvII), em sua introdução à "Retórica a Herênio", comenta que as escolas retóricas latinas realizavam a declamação conforme os manuais, os quais refletem a prática escolar. O texto apresenta os exercícios de forma enfática na forma de progymnásmata; estabelece as formas próprias de vários gêneros discursivos: o epidítico (demonstratiuum), o deliberativo (deliberatiuum, deliberationes, suasoriae), e judiciário (iudiciale, causae, controuersiae). Deve-se notar que o autor desenvolve alguns exemplos de declamações certamente inspiradas nas declamações gregas. Algumas destas discutem sobre o tema da paz e da guerra.

\subsubsection{Cícero}

Erasmo considerava Cícero, entre outros autores, uma autoridade no que diz respeito à composição em prosa (Epístola 20, Steyn, 15 de maio de 1489, 1974, p. 31). Segundo Chomarat (1981, p. 935), Mendelson (1994, p. 94) e Winterbottom (2006, p. 76), na época de Cícero havia duas noções essenciais de declamação que a caracterizam como portadora de

\footnotetext{
${ }^{3}$ Quanto à data, convém citar também outras opiniões, como a do editor da obra para a Belles Lettres, Achard, que palpita: "Elle paraît donc se situer entre le mi de 86 et la fin de 83. Une telle datation s'accorde parfaitement avec l'intention de l'auteur et le contenu du livre" (Achard, 1997: p. vii). E, mais adiante: "Pour toutes ces raisons on peut considérer comme assuré que la Rhétorique à Herennius a été écrite entre la mi-86 et le début de 82 " (Ibid: p. xii).
} 
temas fictícios ou como prática de um exercício da elocução (Kennedy, 1980, p. 37), conforme o sentido escolar do termo $\mu \varepsilon \lambda \varepsilon \dot{\tau} \tau \eta^{4}$

Na obra de Cícero (Bonner, 1949, p. 27), há dez referências à declamação, seja na forma de substantivo, seja na forma de verbo: nas "Disputas tusculanas" (1.7), a palavra ocorre como o sentido de exercício da palavra, mas na oração "Por Plâncio" (4.7), em sentido depreciativo, é atribuída a um discurso banal ou proposição refutável, um protesto barulhento. Nota-se também o sentido de invectivar contra ou sobre uma pessoa (Contra Verres, 4, 49; Epístulas aos Familiares, 3, 11, 2). Cícero também fala do declamator (Por Plâncio, 83) ou do exercício declamatorius (Orador, 47). Há, em Cícero, uma variante para o verbo declamar: declamitare (Epístola LX, a Papirio Paeto). Este último, lido no contexto, parece ter o sentido como exercício veemente da declamação ou da execução reiterada de exercícios de locutio (Brutus, 310; Sobre o orador, 1,251). Pode ser exercido para desprestigiar um contendor (Filípicas. 5, 19) ou para agradar os ouvintes (Disputas Tusculanas, 1, 7). É em Cícero que ocorre a primeira distinção dos subgêneros da declamação quanto ao tipo de causa ou tema: deliberativa ou suasória (Por Rocio Amerino, 82); jurídica ou causae (Disputas Tusculanas, $1,7)$.

\subsubsection{Sêneca, o Rétor ou o Velho}

Manoel (2014, p. 37), contudo, ao tratar dos exercícios de declamação nos tempos de Cícero, em comparação com as declamações do período imperial, reconheceu que "foi após o fim da República que teve início a era das declamações", ou seja, o período no qual sua prática talvez tenha atingido uma espécie de apogeu, devido ao grau de difusão da sua prática na sociedade romana e à maior quantidade e qualidade de registros escritos ainda conservados. Segundo Schwartz (2004, p. 8) e Russel (2009, p. 2), para a compreensão das características fundamentais desse gênero no período imperial, é fundamental considerar as “Controvérsias" (em dez livros) e as "Suasórias", de Sêneca, o Velho. Este discorreu sobre o gênero declamatório nos prefácios às controvérsias escritos provavelmente nas décadas de 20 ou 30 d. C.. A importância desse autor se verifica por ter vivido em uma época na qual a declamação passou a ser realizada publicamente, a fim de deleitar a audiência e tomando o

\footnotetext{
${ }^{4}$ Deve-se ainda acrescentar que além do sentido de exercício, o termo tinha o sentido de cuidar. Era usado inclusive no contexto militar e medicinal (Cf. Bailly, Anatole, Le Grand Dictionnaire Grec-Français, Paris: Hachette, 2000. Voz $\mu \varepsilon \lambda \varepsilon \dot{\tau} \tau \eta)$.
} 
lugar da antiga oratória (Conte, 1999, p. 404). Redigidas em idade avançada, suas declamações judiciais podem ser entendidas como escritas a pedido de seus filhos, ou para a instrução destes (Schwartz, 2004, p. 80), dadas as diversas referências e locuções direcionadas explicitamente a estes em vários prefácios (Sêneca. Contr. Pr. 1, 3, 4, 6, 9, 10, 13, 19, 20, 22). Segundo Bloomer (1997, p. 204), esta indicação de destinatários consanguíneos não deve ser entendida senão como uma estratégia retórica com um significado social, a fim de simular uma recomendação à comunidade ou um ensino a discípulos. Sobre os destinatários desta declamação, conforme afirma Bernstein (2009, p. 332), baseando-se em Sêneca (Contr. II, 4, 12-13), os produtores e consumidores da declamação romana eram membros da classe alta, conforme acima mecionamos.

As "Controvérsias" abordam setenta e quatro casos legais imaginários, nos quais o autor estabelece pareceres dos rétores sobre cada caso a partir de diferentes pontos de vista (Salum, 2010, p. 119). Nos prefácios, apresentam-se as características individuais dos rétores, as quais são discutidas de forma irônica e/ou pedagógica. As controvérsias de Sêneca, porém, não são escritas de forma completa, tal como foram ou teriam sido pronunciadas, mas de forma sintetizada (Schwartz, 2004, p. 8). Estas se diferenciam das declamações escritas em grego, cuja transcrição era integral, sendo redigidas tais como haveriam de ser pronunciadas, a exemplo de Libânio, Corício e Plutarco.

A obra de Sêneca goza de eminente autoridade para a história da oratória e da declamação. Na opinião de Salum (2010, p. 119), as “Controvérsias” apresentam uma espécie de galeria de declamadores, os quais personificam compreensões retóricas diversificadas. Além disso, também evoca uma distinção da declamação em relação à oratória e procura estabelecer as qualidades imprescindíveis do gênero, conforme consta no prefácio da terceira controvérsia (Contr. III, pr. 7).

Segundo a leitura dos prefácios, denota-se que seu orador "ideal” era Cícero, o qual é apresentado inclusive como o primeiro dos declamadores latinos (Schwartz, 2004, p. 12), embora essa afirmação possa contrariar o que o próprio Sêneca pensava a respeito da declamação no final da República: "Cícero, porém, não declamava então estas a que chamamos controvérsias, nem aquelas outras, que eram pronunciadas antes de Cícero, e que se chamavam thesis... Nós dizemos controvérsias, mas Cícero lhes chamava causas" (Sêneca. Contr. I. pr. 12). Além do problema de que algumas das causas ciceronianas poderiam ser 
reais (históricas) e não fictícias, deve-se afirmar que o texto supracitado de Sêneca problematiza a terminologia acerca da declamação, como ao afirmar que Cicero causas vocabat.

Sêneca, cujos prefácios estabelecem a declamação como um gênero literário autônomo em relação à oratória, apresenta alguns conceitos imprescindíveis para sua caracterização, tais como a noção de sententia, entendida como frase epigramática utilizada para impressionar o leitor, ou os ditados ou aforismos, geralmente conclusivos do argumento; a diuisio, que seria uma breve apresentação do esquema argumentativo, proposto era fundamentada nas noções de iustitia (justiça), no ius (direito) e na utilitas (interesse); e o color, entendido como "o estilo com o qual o declamador apresenta a situação, ou seja, contava-se a acumulação de figuras retóricas, o ritmo do período, etc" (Conte, 1999, p. 405). Por outro lado, Schwartz (2004, p. 9) entende que o color seria "o motivo imaginado para justificar uma ação de uma personagem em uma controvérsia”. O color, concebido segundo a conceituação de Sêneca no contexto de uma controvérsia, era atribuído ao ato passado do personagem descrito no thema (Fairweather, 1981, p. 32), por vezes, no início: "este color foi usado, e logo atribui a ele desde o princípio" (Contr. I, 1, 24); ou ao longo desta: "Albúcio não narrou, mas erigiu este color desde o iníio até o final" (Contr. I, 1, 24). Sêneca descreve o color do discurso como sendo prudente, temperado, duro, áspero ou severo. Caracteres análogos eram atribuídos a um ou a todos os personagens da controvérsia (Winterbottom, 1980, p. 171). Muitas vezes estava presente logo na narratio, entendida como "uma descrição sobre os principais atos cometidos" (Van Mal-Maeder, 2007, p. 71) e que fornecem o cerne da questão a ser discutida na declamação.

Apesar do testemunho equivocado de Sêneca, o Velho, a respeito da origem da declamação ao mencioná-la como rem post me natam (Contr. I, 12), o estudo deste gênero com base em seu escritos se faz importante não somente em razão das suas considerações acerca das características essenciais acima mencionadas, mas também porque descreveu o contexto histórico e a prática desta forma de discurso em seu tempo como uma espécie de retrocesso qualitativo (Sêneca. Contr. I. pr. 6.). Conte (1999, p. 404) observa que justamente a mudança de regime político, da República ao Império, fez com que a declamação se alterasse, pois a prática oratória não gozava da mesma liberdade de expressão de antes, com a decadência do Senado e a ausência de prática oratória na formação do orador. Os oradores 
passaram a ser vistos com desconfiança por uma administração que não tolerava críticas. Não sem razão, os autores notam a decadência da eloquentia após a morte de Cícero, não pela falta de gênios, mas pela falta de liberdade de expressão da opinião política individual (Schwartz, 2004, p. 91). Entretanto, a prática das declamações se tornou um espetáculo público e paulatinamente foi tomando o lugar da "robusta oratória expressa pelos tempos de Cícero" (Sussman, 1972, p. 197). Schwartz sintetiza o papel e as incongruências da prática da declamação no período republicano e sua herança para a literatura latina:

...[as declamações] pelo fato de não fazerem parte do campo tradicionalmente mais livre da poesia, nem de serem tampouco redutíveis à simples função ancilar de exercício escolar, colocava-as em um "não-lugar". Essa orfandade, no entanto, resultou em um vazamento da retórica escolar sobre os outros gêneros discursivos. Nesse processo, é todo o campo da eloquência que se torna "declamatório" (Schwartz, 2004, p. 10).

Nos prefácios das "Controvérsias", Sêneca desaprovava as tendências floridas da oratória de seu tempo ou, conforme supõe Salum (2010, p. 119), apresenta personagens como portadores de defeitos e virtudes da declamação, a fim de teorizar sobre características essenciais desta. Para citar um exemplo, uma passagem do prefácio da segunda controuersia expressa uma crítica ao estilo asiático de um aluno de Aréllio Fusco que tinha certa propensão à filosofia, Fabiano Papírio: "seu arranjo de palavras efeminado demais para que um espírito que se prepara com preceitos tão santos e rigorosos pudesse suportá-la" (Contr. II, 1). Sêneca criticou a atividade de alguns declamadores, aos quais atribuía o anseio impreterível de impressionar o público através de vazias frases de efeito pelo uso inapropriado das sententiae, marca essencial do gênero declamatório. A sentença é um silogismo incompleto, mas não ilógico, que prestigia as informações de interesse do declamador e que visa a impressionar o ouvinte, não tanto pelo silogismo, mas pela beleza ou força da expressão. Nessa estrutura, a noção de sententia era fundamental, pois "esta procurava produzir o efeito mais do que a lógica do período" (Salum, 2010, p. 119), ainda que não abstraída a dimensão retórica do logos. Utilizava, no entanto, o entimema, que, segundo a conceituação aristotélica, não era ilógico, mas apenas apresentava o raciocínio de um modo incompleto e essencial a fim de ser compreendido de forma mais direta pelo ouvinte, ou mesmo enganá-lo, e tornar o argumento irresistivelmente persuasivo em contraponto com o raciocínio dialético, desenvolvido em todas as suas premissas, porém menos convincente:

Entre as provas fornecidas pelo discurso, distinguem-se três espécies: umas residem no caráter moral do orador; outras, nas disposições que se criaram no 
ouvinte; outras, no próprio discurso, pelo que ele demonstra ou parece demonstrar. Obtém-se a persuasão por efeito do caráter moral, quando o discurso procede de maneira que deixa a impressão de o orador ser digno de confiança [...] Obtém-se a persuasão nos ouvintes, quando o discurso os leva a sentir uma paixão [...]. Enfim, é pelo discurso que persuadimos, sempre que demonstramos a verdade ou o que parece ser a verdade, de acordo com o que, sobre cada assunto, é suscetível de persuadir (Aristóteles. Retórica. I, 2, 3-8, tradução Antônio de Carvalho, 1999, p. 33-34).

Silogismo significa basicamente calcular ou raciocinar em conexão. Uma das características desse tipo de discurso é a formação completa da sentença lógica, que através de proposições compostas atribuem verdade ou falsidade ao conceito exposto. No discurso dialético, essas proposições compostas são muitas vezes interligadas por conectivos conformando assim orações coordenadas ou subordinadas. Por isso, Aristóteles atribuía ao discurso retórico a necessidade do conhecimento adequado das emoções e das paixões humanas. $\mathrm{O}$ homem não é persuadido pelo mero raciocínio. É necessário apelar às emoções. Tal propósito foi perseguido pela oratória, sobretudo, no ambiente republicano, e sua "herdeira" nos tempos imperiais, a declamação.

Por outro lado, segundo Conte (1999, p. 405),

Dado o caráter fictício das situações e as muitas premissas, o anseio do orator não é tanto persuadir, mas sim deixar a audiência atônita, e ele, para isso, recorre aos mais engenhosos truques da linguagem e da imaginação. O maneirismo das formas torna exagerado o uso dos colores, o termo técnico que indica a manipulação inteligente de uma situação ou de um conceito e capaz de apresentar a matéria em mãos sob o aspecto mais surpreendente. $\mathrm{Na}$ busca do efeito, e dos aplausos do auditório, o orator também faz uso de um estilo precioso, brilhante, aquele que recorre a todos os artifícios de asianismo, do acúmulo de figuras retóricas a uma expressão densamente epigramática a fim de cuidar do ritmo do período.

Sêneca também caracteriza a declamação com dois traços distintivos: em primeiro lugar, ao tratar da pública, afirmava que esta visava a dar impressão de improviso por meio da velocidade (Contr. IV, 7). Em segundo lugar, além da aparência de algo não preparado, deveria ter especial cuidado com o tom de voz, tal como os manuais, como a "Retórica a Herênio", preceituavam. Um orator ou um ou um rhetor era desprestigiado caso seu trabalho fosse assemelhado ao teatro cômico (Instituição Oratória, II, 10, 7-8), uma vez que, em Roma, os costumes dos artistas que atuavam na comédia eram extremamente mal vistos. E, de fato, a comédia era exercida por profissionais desprezados na alta sociedade romana. Desse modo, muitas vezes atribuía-se àquele que atuava uma depravação moral contra os costumes e 
o mos maiorum. A sua ação (actio) se caracterizava exagerada e a modulação no volume da voz a fim de se fazer ouvir e entender adequadamente pela assembleia eram desagradáveis em comparação à oratória "profissional" dos oradores do Fórum e do Senado. Como a recitação da declamação implicava no uso de uma locutio, por vezes, enfática, somada ao uso da prosopopeia, os declamadores procuravam fugir do perigo de serem considerados meros comediantes. Disso resulta a grave crítica ao perigo de incorrer no ridículo, como Sêneca impunha àqueles que não regulavam bem a tonalidade da voz (Contr. IV, 10).

\subsubsection{A suasória em Sêneca}

Como dissemos, as declamações de Sêneca estavam subdivididas em dois tipos: as controuersiae e as suasoriae. As controvérsias pertencem ao gênero judicial e consistiam no julgamento de um caso fictício que se baseava na legislação romana ou em leis fictícias (Bonner, 1949, p. 258). Já as suasórias fazem parte do gênero deliberativo e versavam sobre temas mitológicos e históricos. Nelas, o aluno tinha a finalidade de simular adequadamente o discurso de uma personagem, convencer a assembleia fictícia segundo o propósito de sua causa e deleitar o público real por meio de uma simulação de discurso estruturado com uma prosopopeia. Esta personificação deveria simultaneamente se adaptar ao objeto (res), ao público e à personagem que representa. Daí se conclui a relação da personificação com a noção aristotélica de êthos, mencionada acima, e a sermocinatio, tal como comenta Schenk (1982, p. 115-116):

A suasoria, uma declamação ensinada nas escolas de retórica, mais do que um exercício elementar lecionado na escola de gramática, exigia um auditório, e sua finalidade era, preponderantemente, a persuasão. Toda suasória era em parte uma interpretação, pois o discípulo, ao compô-la, tinha de assumir um papel de preceptor ou conselheiro, e, portanto, tinha de adaptar seus "argumentos, seu modo, sua tonalidade, ao tipo de ouvinte quem quer que fosse, seja um cidadão comum, um soldado, um senador, um membro do conselho militar, um mensageiro, em conformidade com as circunstâncias do debate" (Bonner, 1949, p. 285). Mas o discípulo também tinha de convencer a figura histórica ou mitológica específica que eles estavam aconselhando, ao modo de actio. O jovem aluno deveria aconselhar, por assim dizer, os espartanos a resistir nas Termópilas, ou Agamenon a sacrificar sua filha Ifigênia ou não.

Merecem especial destaque as suasórias I, II, IV, que tratam sobre a deliberação da conquista dos mares e da guerra, com argumentos a favor e contra. A primeira "Suasória", mencionada na Controuersia (VII, 7, 19), trata sobre Alexandre, o Grande, rei da Macedônia. 
O declamador coloca-se no lugar de um dos membros do conselho e discute se, após a conquista da Ásia e da Índia, o monarca deve atravessar o oceano. Já na segunda "Suasória”, que é intitulada "Os trezentos espartanos enviados contra Xerxes, uma vez que os grupos de trezentos enviados de toda a Grécia fugiram, deliberam se também eles próprios fugirão”, trata sobre o episódio dos 300 espartanos que haviam enfrentado os persas, comandados por Xerxes, por ocasião da segunda invasão (480 a. C.) em Termópilas (Cf. Heródoto. História, VII). Nesta suasória, vários declamadores apresentam argumentos a favor e contra a fuga dos espartanos. Destaca-se o discurso de Fusco, segundo Sêneca.

Nesta suasória, Fusco usou aquela divisão popular, dizendo que não era honroso fugir, mesmo que fosse seguro; em seguida, que era igualmente perigoso fugir ou lutar; e, por último, que era mais perigoso fugir. Os inimigos deviam ser temidos por aqueles que lutam; tanto os inimigos quanto os aliados deviam ser temidos por aqueles que fogem (Suas. II, 11, Tradução de Costrino, p. 2010, p. 58).

A segunda "Suasória" traz como tema tipicamente deliberativo questões que evocam a guerra e o ofício do combatente como algo digno, vendo-a como algo positivo, honesto. Alguns declamadores vituperam aqueles que fogem da guerra, apresentando o fato como algo desonroso para os antepassados e que diminui a fama dos gregos.

Na quarta "Suasória", cujo título "Alexandre, o grande, delibera sobre se invadirá a Babilônia, uma vez que lhe fora anunciado o perigo pela previsão do áugure”, encontramos o episódio da vitória de Alexandre sobre Dário, na batalha de Galgamela, ocorrida no ano de 331, a. C.. Com esta conquista, o comandante grego vislumbrou a oportunidade de apoderarse da cidade mesopotâmica. Nesta suasória, mais uma vez, a guerra é tratada como algo benéfico, sobretudo para a imagem do comandante. O augúrio não quer senão incutir o medo no combate, pois tanto a vida de cada homem, quanto o destino dos conquistadores, "são forjadas para cada um por causa do engenho, não a partir da fé” (Suas. IV, 3). Por essas duas passagens, percebe-se não somente que a questão da guerra e, por oposição, da paz, é própria do gênero da declamação suasória, mas que a guerra pode ser tratada como uma causa honesta, no sentido de que é admirável e justa, que predica a virilidade, a legítima defesa da pessoa e da nação, e que argumentos baseados na mitologia não poderiam torná-la uma causa torpe. Em outras palavras, a guerra seria uma deliberação necessária, justa e admirável em certos casos. 


\subsubsection{Quintiliano}

Erasmo qualificava a "Instituições Oratórias" de Quintiliano como escritos de autoridade no que diz respeito à composição em prosa (Steyn, 15 de maio de 1489, 1974, p. 31). Dentre as sessenta e quatro ocorrências de substantivos e verbos com o radical declama(declamator, declamare, declamatio), ${ }^{5}$ foi oportuno selecionar quatro aspectos significativos da declamação: primeiro, sua relação com a oratória (Instituição Oratória, III, 8, 49); segundo, sua prática escolar (Ibid., II, 1, 1); terceiro, a presença, nela, de aspectos teóricos do gênero deliberativo (Ibid., III, 4, 7); e, por último, a ocorrência, nela, do vitupério e do elogio (Ibid., II, 4, 22). Não sem propósito, a prolixidade de Quintiliano a respeito fez com que lhe fossem atribuídas às coleções de declamações maiores, hoje comprovadamente espúrias, dada a presença nelas do asianismo, ausente dos demais escritos dele. As declamações minores, entretanto, poderiam ser atribuídas a ele sem maiores dificuldades (Reali e Turazza, 2012, p. 7).

Do ponto de vista histórico, Quintiliano compartilha a supracitada ideia de Tácito (Dialogo de Oratoribus, 35,1), segundo a qual, a declamação seria uma pobre e mera imitação da antiga e célebre oratória romana, em razão de sua natureza fictícia:

De fato, o que tomamos como exemplo possui uma natureza e força reais; ao contrário, toda imitação é construída e se acomoda a um propósito alheio. De onde sucede que as declamações tenham muito menos sangue e força que os discursos, pois a matéria que é verdadeira nestes, é imitada naquelas. Acrescente-se que o que é ótimo na oratória são as coisas imitáveis, não são o engenho, a invenção, a força, a desenvoltura e o que quer que seja concedido pela arte (Quintiliano, Instituição Oratória, X, 2, 11-12).

Quintiliano comenta que a ascensão do gênero declamatório significou a decadência da oratória romana segundo os elevados moldes ciceronianos em uma relação causal (Schwartz, 2004, p. 2), pelas seguintes razões: o caráter fantasioso dos temas selecionados, que ele rejeitava veementemente, e o estilo exagerado dos declamadores (Quintiliano. Instituição Oratória, II, 10, 1-15), que, segundo ele, quanto menos preocupados com a causa que discutiam, mais pensavam "em deleitar os ouvidos da audiência, mesmo à custa das mais ínfimas distrações" (Ibid., II, 12, 6). Não devemos, contudo, ver nessas afirmações algo como o estado histórico das declamações em seu tempo, pois muitas dessas declarações têm

\footnotetext{
${ }^{5}$ As ocorrências do radical escolhido (declama-) foram contadas numa versão digitalizada da edição da Institutio Oratoria publicada pela Harvard University Press em 2006.
} 
finalidade pedagógica, dada a natureza da Instituição Oratória, podendo ser também interpretadas como uma apresentação de um modelo ou exemplum negativo e que não deve ser seguido ou imitado.

De fato, Quintiliano almejava uma declamação que preparasse os estudantes para as reais necessidades e desafios do fórum e da tribuna, e, por isso, rejeitava a abordagem de temas mitológicos (Vasconcelos, 2004, p. 214). Sua preocupação se explica, pois, pela própria finalidade didática de seus escritos. Como considerava a declamação o "mais útil de todos os exercícios oratórios" (Instituição Oratória, II, 10, 1-2), forneceu um bom retrato de como estes exercícios eram realizados em sua época (Ibid., II, 10, 1-15). Por fim, deve-se dizer também que menciona a prática de prover seus alunos com subsídios escritos, a fim de que estes auxiliassem seus discípulos em suas declamações (Ibid., II, 6, 2), e chega a afirmar que "o exercício da escrita facilitava a locução, e o exercício da locução incrementava a escrita" (Ibid., X, 7, 29). Assim, se era um exercício essencialmente oral, cuja finalidade era a prática da locutio, é justamente em Quintiliano (Ibid., X, 3, 10) que surgem alguns indícios de uma declamação escrita no contexto escolar (Murphy, 2012, p. 69). Esse processo corresponde à tendência de transcrição dos discursos forenses, que também passaram a ser concebidos para a leitura, e não somente para a audição, em decorrência, talvez, da decadência da oratória então mal vista pelo regime imperial (Williams, 2009). Esse fenômeno, denominado literalização, foi um processo que transparece numa prática que se estabeleceu naquela tempo e que se assemelha à prática declamatória: as recitationes (Conte, 1999, p. 405). Estas costumavam anteceder a publicação das obras, não se restringindo aos gêneros poéticos, como os epigramas de Marcial e as sátiras de Juvenal, mas abrangiam também prosas de historiadores e epístolas, como as de Plínio, o Jovem entre outros gêneros discursivos (Dupont,1997, p. 45). As declamationes e as recitationes implicavam em um contexto oral de emissão e recepção, pois, embora minuciosamente preparadas e escritas, não visavam a convencer, mas, sobretudo, a deleitar (Schwartz, 2004, p. 15).

Quintiliano informa que em seu tempo a declamação também poderia versar sobre temas deliberativos ou suasórios (Insitutição Oratória, III, 8, 61) ou sobre as causas judiciais (Ibid., II, 1, 9). É ele também quem trata do lugar do elogio e da censura dentro da declamação e relaciona esses elementos típicos do gênero epidítico como lugar comum: 
Lugares-comuns (falo daqueles em que não se especificam pessoas e é usual declamar contra vícios, como contra aqueles do adúltero, do jogador, do licencioso) são da própria natureza dos discursos em exercícios; e, se tu acrescentas o nome da parte acusada, são autênticas acusações. Estes, no entanto, geralmente são tratados a partir de temas gerais para algo específico, como quando o assunto de uma declamação é um adúltero cego, um jogador pobre, ou um velho licencioso. Às vezes, também têm a sua utilização na defesa quando ocasionalmente falamos em favor do luxo ou da licenciosidade; ou de um degenerado ou parasita é por vezes defendido da forma que defendemos não a pessoa, mas o vício (Ibid., II, 4, 22).

Além de tratar da inadequação da declamação com a comédia, ao exemplicar com as figuras antitéticas do adúltero cego, do jogador pobre e do velho licencioso, Quintiliano discute sobre algumas formas de distinguir os tradicionais três gêneros de discurso (deliberativo, judicial e epidítico) e afirma a interpenetração que pode haver entre estes:

Há, então, como eu disse, um gênero que contém o louvor e o vitupério, mas que é chamado, pelos melhores, de laudativum; outros, no entanto, chamamno de demonstrativo. Acredita-se que ambos os nomes sejam derivados do

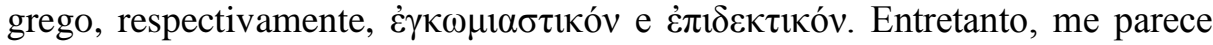

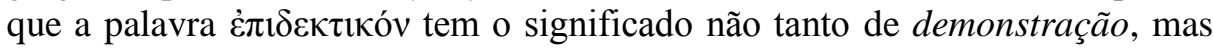

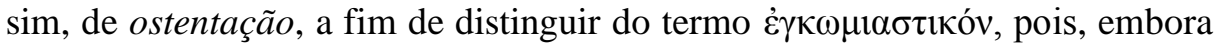
ela inclua em si o gênero laudativum, não consiste somente nesse tipo.

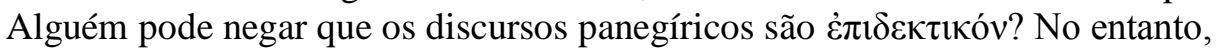
eles tomam a forma suasória e geralmente tratam dos interesses da Grécia. De modo que há, de fato, três gêneros, mas, em cada um deles há uma parte dedicada ao objeto e outra parte à ostentação. Mas quando, não traduzindo do grego, chamam de demonstrativo, são simplesmente levados pela consideração de que o elogio e a censura demonstram o que é a coisa. $\mathrm{O}$ segundo tipo é o deliberativo e o terceiro, o judicial. Outras espécies incorrerão nestes gêneros, sem haver encontrado uma espécie qualquer em que não deve elogiar ou censurar, persuadir ou dissuadir, para impor uma carga ou repeli-la. Nelas é comum conciliar, narrar, ensinar, aumentar, diminuir a fim de influenciar o julgamento do público, excitando ou dissipando as paixões. Eu não poderia concordar mesmo com aqueles que, ao adotar, segundo meu parecer, uma divisão mais fácil e ilusória do que verdadeira, consideram que o laudativo diz respeito ao que é honesto (honroso); o deliberativo ao que é conveniente (útil); e o judicial, ao que é justo; todos são em certo ponto auxiliados uns pelos outros, uma vez que no elogio são consideradas a justiça e a oportunidade, e nas deliberações, a honra; e raramente encontrarás uma peça processual judicial na qual não ocorra em alguma parte algo do que mencionei acima (Ibid., III, 4, 12-16).

Para Quintiliano, os três gêneros não são categorias estanques completamente separadas, mas um auxilia o outro na medida em que compartilham elementos e recursos de argumentação, como é o caso da utilidade, da justiça e da honra atribuída ao ato ou à pessoa de um determinado personagem que se ataca ou defende em uma causa. Ao gênero epidítico, embora esteja inserido na tradicional tripartição genérica, está reservado "um papel residual 
na organização do sistema” (Schwartz, 2004, p. 147). Quanto ao lugar do demonstrativo, trata-se de um dos assuntos mais controversos da retórica antiga, mas prevalece que está inserido como lugares comuns dentro dos demais gêneros, de modo que, caso fosse assumida a definição a partir de uma orientação discursiva (laudare ou vituperare), seria lógico que também fossem acrescentados outros gêneros segundo este critério, como a repreensão (obiurgatio), a exortação (cohortatio), a consolação (consolatio), entre outros (Cícero, Sobre o Orador, II, 47, 50). Quintiliano (Ibid., III, 4, 9-14) antepõe uma característica do gênero epidítico em relação aos gêneros deliberativo e forense. $O$ primeiro visa ao deleite e não exige de seus ouvintes a tomada de uma decisão, como o realizar ou não um ato ou estabelecer a culpabilidade ou a inocência em um caso, mas sim o assentimento. $\mathrm{O}$ demonstrativo visa a deleitar a fim de persuadir. Segundo Schwartz (2004, p. 149), “a característica universalmente aceita do gênero [é] o caráter passivo do público, que só conta como apreciador estético dos discursos".

É de Quintiliano, por fim, a referência teórica escrita em latim mais antiga da figura prosopopeia aplicada ao gênero declamação: para ele, os discursos suasórios que envolvem a prosopopeia são "os mais difíceis de pronunciar" (Ibid., II, 1, 2). Segundo Van Mal-Maeder (2007, p. 53), uma vez que a principal finalidade da caracterização das personagens era "de despertar a simpatia ou, ao contrário, de suscitar a indignação, elas têm uma capacidade ilustrativa que os declamadores se compraziam em usar na demonstração”. Autores como Clark (1957, p. 218) e Bonner (1949, p. 285) identificaram essa figura de linguagem, que também eram progymnásmata (Hélio Teão, Progymnásmata. 60), com uma característica essencial da declamação, conforme acima citamos (Ibid., III, 8, 49).

Segundo Aristóteles (Ética a Nicômaco, I, 3), os jovens, por carecerem de experiência de vida, não eram aptos à política. Justamente em razão deste particular, Clark (1957, p. 218) observa que os discípulos eram exercitados em declamações de temas histórico-mitológicos fictícios e que deveriam simular um diálogo em proximidade com personagens importantes da história e da mitologia greco-romana, tais como fatos biográficos de Sula, Sócrates, Alexandre, César ou Cícero (Mendelson, 1994, p. 94). Note-se que a utilização de temas mitológicos e históricos não tem a finalidade de distinguir entre o caráter histórico e mitológico, mas sim simular adequadamente o discurso segundo o estereótipo corrente formado a respeito dessas personagens. Desse modo, os estudantes eram estimulados a 
compor prosopopeias, no sentido em que uma personagem ausente, geralmente inspirada na história ou na mitologia greco-romana, toma a palavra para fazer um discurso. Shenk (1982, p. 116-118) também observa a ocorrência relevante do uso da prosopopeia nas declamações deliberativas ou suasoriae: "muitas controvérsias, assim como todas as suasórias, foram compostas como prosopopeias nas escolas de declamação”. Segundo Winterbottom (1974, p. 52), estas, no sentido de um discurso do personagem simulado, seriam uma espécie de suasória. Dessa forma, averigua como, no gênero declamatório deliberativo ou suasório, a prosopopeia era um elemento essencial da declamação. Isso ocorre, talvez, devido ao poder persuasivo dessa figura. Quintiliano identifica a prosopopeia das causas fictícias com os diálogos, tão utilizados pelos autores greco-romanos em temas filosóficos:

Entre aquelas coisas que são ainda mais audaciosas e, como pensa Cícero, que exigem maior empenho, está a personificação ou $\pi \rho 0 \sigma \omega \pi$ o $\pi$ oï̌ $\alpha$. Este recurso fornece à oratória maravilhosa variedade e animação. Por esse meio, exibimos os pensamentos mais íntimos dos nossos adversários, como se estivessem falando com eles mesmos (mas ela só convencerá se os representarmos no que é verossímil presumir que ocorra em suas mentes); ou ainda, sem sacrifício de credibilidade, pode introduzir conversas entre nós e os outros, ou de outras pessoas entre si, e colocar palavras de conselho, reprovação, reclamação, elogio ou pena na boca de pessoas apropriadas; ademais, por meio destas prosopopeias é possível trazer dos céus os deuses, evocar a morte, e dar vozes a cidades e Estados. Há autores que dão o nome de prosopopeia só àquelas em que há ficção de personagens e de discursos. Quanto às outras, em que há homens a falar, dão-lhe o nome de diálogos, preferindo o termo grego ao latino, utilizado por muitos, que quer dizer conversação (sermocinatio). Eu, porém, seguindo o uso, dei o mesmo nome a uma coisa, e a outra; pois não é possível imaginar locuções sem imaginar as pessoas que falam (Ibid., IX, 2, 29-32).

Dessa forma, segundo o argumento de Quintiliano, os limites entre a declamação suasória ou epidítica não estariam definidos de modo suficiente em razão da ocorrência de personagens com discursos diretos, cujo conteúdo e estilo estão adequados com o ethos de cada personagem. Não se poderia, então, falar de declamação latina epidítica, mas de contextos epidíticos.

Por outro lado, para Mendelson (1994, 94), Quintiliano recomendava que a actio considerasse não somente o caráter da personificação que falava, mas também aquele de seu auditório, como o número de ouvintes, seu status, nacionalidade, especificidade, partido e, acima de tudo, seu caráter moral (Ibid., III, 8, 37-38). Quintiliano o exemplifica com as 
Catilinárias, na qual Cícero dá voz à Pátria e à República (Catilinárias, 7,18; 11, 27), entes figurados, seres abstratos que também tomam a voz na declamação. Embora Quintiliano apenas pareça apresentar a prosopopeia como um fator de dificuldade, e, por consequência, algo que atribui maior mérito para aquele que soubesse adaptar de modo adequado os caracteres das personagens evocadas à temática em causa e aos gostos do auditório, parecenos ponderado afirmar que ela é uma característica essencial da declamação suasória, pois adaptar a figura fictícia com o tema e a assembleia seria a finalidade mais específica do exercício declamatório (Bonner, 1949, p. 285). Parece ser incoerente pensar em uma declamação sem a prosopopeia ou mesmo sem uma personificação.

\subsection{A recepção dos autores antigos no Renascimento}

Segundo Mack (2004, p. 261), “o renascimento da retórica clássica poderia ser caracterizado com três palavras: recuperação, adição e renovação". A recuperação pode ser entendida, entre outros sentidos, como a retomada de um corpus de textos greco-romanos antigos, muitos desaparecidos e desconhecidos pelos autores cristãos medievais e que constituem basicamente o corpo de escritos com os quais ainda hoje se toma contato com a Antiguidade greco-romana. A adição teria sido o acréscimo de novos recursos literários oriundos do acúmulo cultural ao longo dos séculos. Trata-se de uma espécie de simbiose entre a cultura greco-romana e a cristã com seus diversos contatos com o oriente. A renovação seria justamente esse adaptar-se aos novos tempos, às novas aptidões e sensibilidades artísticas com a conformação de um movimento cultural amplíssimo, capaz de penetrar em praticamente todas as artes e ciências: o Renascimento.

Como se verificará na recepção da declamação enquanto gênero literário e pedagógico, faz-se necessário pontuar que o Renascimento surge basicamente a partir de dois fenômenos de índole literária: primeiro, com a recuperação de textos antigos que não tinham sido conhecidos ou difundidos ao longo da chamada Idade Média; e, em segundo lugar, com o surgimento da imprensa, que permitiu a difusão desses textos nos círculos letrados em escala até então impensável (Sartorelli, 2009, p. 3). Para Murphy (2003, p. 227). Se de um lado havia o acréscimo de fontes àquelas chamadas "cristãs", verifica-se uma mudança de visão de mundo, que não tratava das coisas segundo uma visão teocêntrica, mas que colocava o homem no centro de tudo. 
O Renascimento conteve duas tendências históricas: o Humanismo e o cientificismo, aspectos marcantes do período histórico que passava a chamar-se "moderno". O primeiro movimento, atribuído a uma classe de pessoas denominadas como humanistas, consolidou-se na península itálica, e caracterizava-se por um conjunto de ideais ou princípios que valorizavam a razão e as ações humanas segundo determinados valores morais como o respeito, a justiça, a honra, o amor, a liberdade, entre outros. O movimento se se afirmava em contraposição ao "teocentrismo" da "Idade das Trevas" atribuída ao medievo, em uma visão que embora se assemelhe ao iluminismo é contrariada pela historiografia contemporânea. Como decorrência desse antropocentrismo, o desenvolvimento das artes também foi uma característica desse movimento, que no âmbito das Letras, a partir da recuperação dos gêneros antigos, se pautou no interesse crescente pelos princípios da antiga retórica, entendida como um conjunto de princípios explicitados pelos autores gregos e latinos, especialmente da Antiguidade, que abordavam a arte da eloquência ou da argumentação tendo em vista a persuasão e o deleite de um auditório.

Dois dados apresentados por Murphy (2003, p. 231) exemplificam esse interesse crescente em relação à Retórica: entre a edição da primeira obra de Cícero (o Sobre o Orador), datada de 1465, e o ano de 1500, contabilizaram-se 332 publicações impressas, ao passo que houve apenas 154 edições das obras de Aristóteles, cujo predomínio de temáticas filosóficas é notório (Murphy, 2003, p. 231). Tendo em conta que muitas das obras ciceronianas abordavam principalmente temas típicos da retórica e que, ao final de 1485, estas já tinham sido editadas e impressas (Revard, Rädle e Di Cesare, 1988, p. 522), sua figura cresceu em importância de modo que muitos elementos retóricos geralmente atribuídos a outros autores antigos foram recebidos pelos humanistas por intermédio da leitura de seus escritos (Sartorelli, 2015, p. 7).

Por outro lado, a invenção da imprensa fez necessária a entrada de um número ainda maior de leigos para os trabalhos tipográficos:

Uma das principais consequências da invenção da prensa tipográfica foi ampliar as oportunidades de carreira abertas aos letrados. Alguns deles se tornaram letrados-impressores, como Aldo Manutius em Veneza. Outros trabalhavam para impressores, por exemplo, corrigindo provas, fazendo índices, traduzindo ou mesmo escrevendo por encomenda de editoresimpressores. Ficou mais fácil, embora ainda fosse difícil, seguir a carreira de "homem de letras" (Burke, 2003, p. 28-29). 
Nem mesmo após as controvérsias teológicas acentuadas pela Reforma Protestante, que teve seu marco inicial com as teses de Lutero afixadas nas portas da catedral de Winterberg em 1517 - mesmo ano de publicação da "Queixa da Paz" -, e a crescente oposição entre os vários credos cristãos, as trocas epistolares se restringiram entre as confissões religiosas (Vasoli, 2008, p. 6; Hernández Guerrero e García Tejera, 1994, p. 102105). Sartorelli (2009, p. 4) observa que este círculo de literatos manteve o latim como língua veicular, utilizando-a como uma língua internacional de comunicação:

... é preciso ter em conta que esse movimento foi, em uma medida de que talvez não nos apercebamos hoje, um movimento essencialmente latino, ou seja, em língua latina. Humanistas, mesmo os helenistas, escreviam sobretudo em latim, e foi em latim que Pico della Mirandola, por exemplo, divulgou Platão. Assim sendo, quando falamos aqui em imitatio, elocutio etc., estamos sempre falando da língua latina.

Em contraste com os séculos anteriores, nos quais as letras estavam majoritariamente restritas ao conhecimento dos clérigos e, embora o volgarizzamento, com a literatura "ficcional", como a de Dante ou Bocaccio, entre outros escritos não estritamente considerados filosóficos e teológicos, essa nova classe de intelectuais, chamados na Itália de humanistae, situava sua atenção em questões linguísticas, poéticas e estilísticas ao privilegiar a arte, a beleza e a persuasão do discurso, mais do que a abstração e a pretensa precisão e uso dos termos muitas vezes repetitivos do texto filosófico (Murphy, 2003, p. 241). Contudo, a maioria dos autores mais eminentes eram membros de ordens religiosas, muito embora os leigos ocupassem um espaço cada vez maior nas escolas ou nas universidades, atuando como professores privados, ou, ainda, como dependentes da liberalidade de patronos ou mecenas, especialmente durante o Renascimento (Vasoli, 2008, p. 6). Esses intelectuais trocavam correspondências e estabeleciam círculos de relações ou centros eruditos com a finalidade de compartilhamento das suas atividades literárias, que posteriormente passaram a chamar-se de academias e se espalharam por toda a Europa Ocidental, a ponto de, no final do século XV, para designar essa corrente, cunhou-se a expressão República das Letras (Moya Bedoya, 2008, p. 192).

A inserção de outros autores fontes para a inventio - além da Bíblia e dos Padres da Igreja, os autores antigos - fez com que a arte de "encontrar" argumentos a favor de uma causa fosse praticada com a leitura de textos de autoridade largamente difundidos pela imprensa, e neste sentido, são os autores greco-latinos antigos, que erasm privilegiados. Estes 
deveriam ser lidos para deles se extrair, por meio do sistema de lugares e tópicos, os critérios que podem ajudar a argumentar com um discurso agradável, harmonioso e realmente persuasivo, tal como predicava a retórica. Assim, o sistema de lugares (loci) se converte em um meio primordial para ler e, ao mesmo tempo, para produzir o discurso (Mack, 1993, p. 130).

Além da invenção, havia o fenômeno da imitação (imitatio) dos antigos modelos greco-romanos, a qual contemplava, principalmente, preceitos de estilo, ou seja, as habilidades verificadas em determinado texto a fim de efetivar a finalidade para a qual foi escrito. Estas habilidades seriam adquiridas através de exercícios baseados em textos latinos e gregos antigos (Cobett e Connors, 1999, p. 411). A polêmica em torno da imitação procurava discutir se esta técnica se restringia somente ao reproduzir fórmulas frasais, opções lexicais e lugares comuns próprios dos antigos modelos greco-romanos nos escritos dos humanistas. As discussões a respeito ocuparam um lugar central ao longo do final do século XIV e no início do século XV. Os autores antigos eram considerados e inclusive venerados como os possuidores do latim por excelência e deveriam servir de modelo para que os humanistas praticassem o "verdadeiro" latim (Sloane, 2004, p. 112), muito diverso do latim praticado pelos autores medievais, mais ocupados em questões dialéticas filosóficas do que com as questões de estilo.

Embora houvesse um certo consenso geral acerca da imitação dos antigos no Renascimento, esse fenômeno não foi de modo algum pacífico ao considerar as particularidades desta imitação. Uma das querelas mais encarniçadas foi o debate em torno do ciceronianismo. Os intelectuais europeus antagonizavam-se em uma tendência de imitação estrita às obras de Cícero e outra forma mais eclética, que também consideravam outros autores antigos (Sartorelli, 2015, p. 13). Erasmo foi protagonista nessa polêmica, sobretudo, ao publicar o seu "Diálogo Ciceroniano" no ano de $1528 .{ }^{6}$ Nesse escrito, o holandês antagonizou a imitação estrita e exclusiva de Cícero realizada por autores que se denominavam como ciceronianos, e que visavam imitar com exclusividade o léxico, a métrica, as declinações e as fórmulas presentes nos textos ciceronianos, a despeito da qualidade dos demais latinos antigos e do contexto histórico e cultural do século XV. Os

\footnotetext{
${ }^{6}$ Recentemente traduzido diretamente do latim para o português pela orientadora do presente estudo (Sartorelli, 2014 e 2015).
} 
ciceronianos antagonizavam com os humanistas "ecléticos", que defendiam a imitação de outros autores e que, embora reconhecessem o valor das obras ciceronianas, também procuravam imitar os demais, reconhecendo inclusive a necessidade de incorporar novas palavras e fórmulas ao léxico latino. Erasmo defendeu publicamente uma imitação eclética ou composta, isto é, que considerasse os autores antigos em pé de igualdade, e inclusive definiu a imitação a partir do ecletismo necessário para atender às diferenças entre oradores por meio da locução de uma das personagens do "Diálogo Ciceroniano":

Eu abraço a imitação, mas aquela que ajudar a natureza, não a que a violar; a que corrigir os dotes naturais, não a que os destruir; aprovo a imitação, mas a que, conforme o exemplo, está de acordo com o teu talento ou que, ao menos, não te opões a ele, para que não pareça um theomachein contra os gigantes. De novo, aprovo a imitação, mas não a dedicada a uma só prescrição, de cujos traços não se atreve a separar-se, mas aquela que de todos os autores ou ao menos dos mais importantes, toma aquele que mais se destaca e o que mais convém a teu próprio talento, colhendo e não acrescentando imediatamente ao discurso tudo de belo que se lhe apresente, mas fazendo-o passar a teu próprio coração, como se fosse ao estômago, para quem uma vez transfundido às veias, pareça nascido do teu próprio talento, e não mendigado de outra parte. Inspirará assim o vigor e a índole de tua mente e de tua natureza, para que quem lê não reconheça o emblema tirado de Cícero, mas sim um feto nascido de teu cérebro, da mesma forma, que, dizem, Palas saiu do cérebro de Júpiter, refletindo a imagem viva de seu pai, e teu discurso não pareça a ninguém um mosaico, mas a imagem viva de teu peito ou um rio emanado da fonte do teu coração. Mas seja tua primeira e principal preocupação a de conhecer a matéria que te propões tratar. Ela prover-se-á copiosidade oratória, prover-te-á afetos verdadeiros e genuínos. Assim, enfim, dar-se-á que teu discurso viva, respire, aja, comova e arrebate, e reflita todo teu ser (Erasmo. Diálogo Ciceroniano. Tradução por Sartorelli, 2015, p. 16).

Veremos como a "Queixa da Paz" também se apresenta como um discurso que recebe e imita expressões, lugares comuns e metáforas correntes em autores antigos não se limitando a Cícero, mas colocando em prática esta imitação eclética defendida por Erasmo.

\subsection{A recepção pelas edições e traduções dos autores antigos}

Convém considerar as mais importantes edições realizadas pelos humanistas diretamente relacionadas ao gênero declamação. Por outro lado, dado o número inabordável de edições, obras e títulos do período, a ponto de Murphy (1983, p. 20-36) enumerar quase dois mil nomes, que estão contidos dentro do epíteto de humanista ou renascentista, deve-se considerar a dificuldade de catalogar a prática da declamação no período. 
Ao selecionar, portanto, algumas declamações entre os humanistas, elegemos aquelas que (grupo 1) os estudiosos de Erasmo consideram que foram conhecidas por ele, e, portanto, o teriam influenciado de modo direto e inconteste, ou aquelas que foram inequivocamente influenciadas por ele (grupo 2). Além desse critério, deve-se considerar, evidentemente, certo prestígio desses autores em relação a outros menos conhecidos, a ponto de serem mais habitualmente levados em conta pela academia. ${ }^{7}$

A declamação, após seu esquecimento quase completo durante o período bizantino (Kennedy, 1980, p. 166) e após uma tímida prática das controvérsias por alguns eruditos do século XI, entre os quais destaca-se Anselmo de Cantuária (Kennedy, 1980, p. 185), passou a ser praticada especialmente pelos humanistas do norte da Itália, muito em razão da redescoberta dos mencionados manuscritos de Sêneca, Quintiliano e Cícero. A retomada da prática da declamação no período renascentista tem seu início delimitado na Itália do século XIV e coincide, segundo o estudo de Giazzi (2008, p. 315-317), com a existência de manuscritos de declamações sob os moldes antigos realizados e encontrados em Milão e anexados ao exempla epistolarum de Visconti, datados nos anos da virada do século XIV para o XV. Segundo Boulet (2013, p. 9),

Um grande número destas declamações foi pronunciado em situação de aprendizagem, em contexto escolar, como indica o imponente trabalho pioneiro realizado por Van der Poel (1987), sob a orientação de Jean-Claude Margolin. Os textos destas declamações pedagógicas foram perdidos, ou são lacunares, ou de um interesse medíocre.

Mas estes autores não gozavam de vários escritos fundamentais para a teorização e exemplificação da declamação antiga: por exemplo, a redescoberta de um dos manuscritos integrais da "Instituição Oratória", no mosteiro suíço de Saint Gall, pelo humanista italiano Poggio Braccioloni, deu-se apenas em setembro de 1416 (Enos, 1990, p. 177; Gómez Cervantes, 2007, p. 424). Este manuscrito, até então, só era conhecido parcialmente, por intermédio do texto chamado de mutilatus. Já as declamações mais antigas consideradas como pertencentes ao humanismo são as quatro declamações de Coluccio Salutati (1331-1406), intituladas em latim: "Declamação de Lucrécia”, "Declamação de Príamo", "Questão contra os decemviri" e "Sobre o reino" (Enos, 1990, p. 177). A redescoberta do diálogo "Sobre o

\footnotetext{
${ }^{7}$ A segunda edição do catálogo de Murphy e Green apresentou 1.717 autores, 3.842 títulos de retórica em 12.325 impressões, publicadas em 310 cidades por 3.340 editores, da Finlândia ao México (Green e Murphy, 2006, p. IX).
} 
orador" por Landriani veio alguns anos depois, em 1421 (Strayer, 1989, p. 24). Data do mesmo período, ademais, o acesso às "Controvérsias" de Sêneca pelos humanistas, uma vez que alguns excertos teriam sido publicados em Nápoles em 1475, e o texto integral, que incluiu as "Suasórias", foi editado em Veneza, em 1490 (Grafton, Most e Settis, 2010, p. 872). O próprio Erasmo foi o responsável por duas edições da obra de Sêneca, datadas de 1515 e 1529, sendo que a primeira edição é anterior ao ano de redação da "Queixa da Paz" (1516) (Grafton, Most e Settis, 2010, p. 872). Desta forma, o conhecimento de Erasmo acerca da declamação não se restringia mais ao manual da "Retórica a Herênio" e ao "Sobre a invenção", como nos tempos de Salutati, mas também passaria a contar com a influência dos demais textos ciceronianos, assim como outros escritos retóricos de Sêneca, o Velho, Isócrates, Platão, entre outros, que ou não eram conhecidos pelos autores cristãos no início do século XV, ou não eram largamente valorizados ou difundidos antes da entrada em cena da imprensa que, sem dúvida, potencializou a difusão dos escritos dos autores antigos da Grécia e de Roma (Murphy, 2005, p. 3).

A redescoberta das declamações e dos textos que teorizam sobre ela, além das traduções de Erasmo de algumas delas escritas em grego, especialmente as de Libânio e Luciano, certamente influenciaram a prática desse gênero pelo holandês, uma vez que a declamação preconizada na retórica ciceroniana, na "Retórica a Herênio" e no "Sobre a invenção", que eram consideradas durante os séculos como os escritos retóricos por antonomásia (Kennedy, 1980, p. 195). Além dessas obras, Knott (1988, p. 8-9) percebe a influência no "Sobre a abundância" (De copia) de parte do livro I e d o II livro da "Instituição Oratória" de Quintiliano, justamente as partes que trazem várias referências teóricas sobre o gênero, além das próprias declamações atribuídas a ele, talvez através da leitura de Valla.

Além da produção de diversos manuais em que constava a prática da declamação em ambiente escolar com finalidade explicitamente pedagógica, Van der Poel (1987, p. 984) salienta a produção desse gênero exterior ao ambiente e ao processo educacional, em forma escrita e literária, tal como praticada por vários autores, entre os quais se destaca a atividade do "príncipe dos humanistas". Em seu "Plano de estudos" (De ratione Studii), por exemplo, Erasmo citava algumas obras fundamentais para a formação de um humanista, na qual se nota a presença explícita das declamações traduzidas por ele, dos temas próprios a tais exercícios e dos escritos que tratavam sobre a declamação, como os de Sêneca (Kennedy, 1980, p. 196). 
Após ser introduzida no norte da Europa, a declamação foi produzida pelos autores renascentistas exclusivamente na forma escrita (Murphy, 2012, p. 69), com entusiasmo não menor do que a recepção do público, conforme se denota pelo alcance editorial que obtiveram, pois algumas das mais relevantes obras literárias do Renascimento foram escritas no formato declamatório, tais como o "Elogio da Loucura" (1511) de Erasmo e as declamações de Thomas More. A declamação chamada "literária", entendida aquela que era exclusivamente escrita e visava o deleite dos eruditos, e não somente a escolar-pedagógica, estava, por assim dizer, "na moda" entre os autores do século XVI.

\subsection{Principais declamadores e declamações renascentistas}

Entre os autores do Renascimento, Van der Poel (2007, p. 128-129) e Tunberg (2006, p. 9) destacam as seguintes obras, algumas das quais anteriores, outras contemporâneas às de Erasmo, e, outras, por fim, posteriores à Querela, como exemplos de declamações paradigmáticas segundo os preceitos herdados da retórica antiga. Apresentamos uma síntese dessas declamações, ressaltando os elementos particulares que são pertinentes para uma comparação com as características da declamação antiga consideradas no primeiro capítulo e a "Queixa da Paz", objeto principal do presente estudo. Dentre estas, se destacam a declamação de Valla (Constatini donatione) e a de More, que foram certamente conhecidas por Erasmo, dada a admiração de Erasmo pelo primeiro e sua amizade pessoal para com o segundo.

\subsubsection{Lourenço Valla}

Em uma de suas epístolas a Cornelis Gerard (Steyn, 15 de maio de 1489, 1974, p. 31), Erasmo afirma que a "Elegâncias da língua latina" (Elegantiae linguae latinae), escrito por Valla, o influenciou significativamente. Para Gianotti (2008, p. 65), os autores humanistas tomavam o italiano como guia "na escolha lexical e estilística". Nessa mesma epístola, após enumerar Cícero, Quintiliano, Salústio e Terêncio como autoridades no tocante à prosa, Erasmo também admitia a superioridade de Valla:

Com efeito, quanto às observações das elegâncias, em ninguém eu tenho tanta confiança quanto em Lourenço Valla; pois não temos nenhum outro a atribuir tanta pertinácia de engenho e tenacidade de memória. Não ousarei, pois, em qualquer matéria, contrariar o que nas letras aconselhou. 
Conforme explicam Bentley (1977, p. 11) e Weiler (1997, p. 9), a influência de Valla sobre Erasmo tem um papel especial em sua formação intelectual, pois já em 1489, o holandês o louvava por restaurar a eloquência em forma escrita e em latim. Como veremos, o italiano também foi um autor profícuo de declamações, que foram conhecidas e emuladas por Erasmo. Bentley (1977, p. 28) inclusive afirma a insistência de Valla na submissão da filosofia à retórica e à filologia, sendo que o holandês o seguiu pelo mesmo caminho, "com o objetivo de renovar a moral e a religiosidade da cristandade" (Bentley, 1977, p. 28), de um modo muito semelhante, e que será explorado ao longo da presente dissertação, nas declamações erasmianas.

Entre as declamações de Valla, conta-se a "Doação de Constantino" (De falso credita et ementita Constantini donatione), escrita em 1440 e publicada em 1517. Nesta declamação muito provavelmente conhecida por Erasmo, o autor, com argumentação histórica e filológica, demonstrou a falsidade da Doação de Constantino, um documento apócrifo com o qual a igreja justifica seu poder temporal. Constantino e o Papa são as personagens históricas que atuam no discurso ficcional, tal como ocorria em diversas declamações latinas.

De fato, a palavra declamação não teria sido inserida por Valla no título, mas pelo editor Úrico Von Huten, de forma que o autor parece não ter tido a intenção clara de escrever uma "declamação" (Ginzburg, 2004, p. xv), pois se pode dizer que a "Doação de Constantino" se assemelha ao gênero diálogo com tema histórico, não filosófico. Esta semelhança remonta ao já citado texto de Quintiliano, já considerado no capítulo primeiro, que dirimia uma sinonímia corrente entre os a declamação e o diálogo devido ao caráter fictício e a presença comum de personificações. Além disso, segundo o argumento de Bowersock (2008, p. ix), a declamação de Valla não poderia ser considerada uma declamação por não apresentar os dois lados da questão. Como vimos, no entanto, nem todas as declamações antigas tinham esse formato. Ao comparar-se a "Queixa da Paz" com a "Doação de Constantino", verificou-se que a primeira, ao contrário da segunda, apresenta uma descrição narrativa no exordium e apresenta em algumas partes caracteres semelhantes da sermocinatio, conforme consideramos no capítulo primeiro, a fim de desenvolver digressões e amplificações de caráter filosófico ou teológico. Ademais, segundo Colemann e Perry (2001, p. 3-4), tal como a Querela, a "declamação" de Valla tem uma finalidade política, ao influir na disputa territorial entre o papa Eugênio IV e o rei Afonso de Aragão, Sicília e Nápoles, para o 
qual Valla trabalhava como conselheiro (Bowersock, 2008, p. vii). Deve-se salientar, por fim, que Erasmo concede a voz à Paz, ao passo, o próprio Valla toma a voz do discurso.

\subsubsection{Thomas More}

A declamação "Tiranicida" (Declamatione qua Luciani Tyrannicidae respondetur) foi escrita por Thomas More (1478-1535) provavelmente em 1506, em emulação a uma declamação erasmiana que também refutava os argumentos do "Tiranicida" de Luciano (Rummel, 1985, p. 50). Como é característico do humanismo, a obra entra, pois, em diálogo extemporâneo e fictício com uma célebre declamação antiga (Baumann, 1985, p. 113). Na obra antiga, Luciano defende a causa do tiranicida, em uma controvérsia com argumentos do gênero forense ou judicial (Thompson, 1974: xviii). More, que também traduziu para o latim a declamação de Luciano (Logan e Adams, 2003: xv), tal como o próprio Erasmo (Chomarat, 1981), não quis apenas respondê-la, como também Erasmo o fizera, mas expôs suas próprias ideias, de modo que os dois textos se relacionam formalmente e divergem em alguns pontos de vista (Fox, 1983, p. 44). O autor inglês defende o argumento de que o tirano será aceitável, se permitir que a cidade recupere a paz e a ordem de Direito. Assim, enquanto Luciano satirizava com ironia a causa do tiranicida, More a vitupera seguindo a prática da declamação que selecionava apenas um lado da contenda.

Erasmo relata a amizade com More e a prática da declamação realizada juntamente com o autor inglês:

Proponho-me agora a falar sobre o assunto daqueles estudos que foram o principal meio de unir-nos, a More e a mim. Na sua primeira juventude, seus principais exercícios literários foram em verso. Depois disso More lutou para tornar a sua prosa mais suave, praticando todo tipo de escrita, para formar um estilo, o caráter do qual será desnecessário lembrar, especialmente a ti, que está sempre com os seus livros nas mãos. Tinha o maior prazer em participar de declamações, escolhendo sempre algum tema polêmico, por envolver um exercício mental importante. Enquanto ainda jovem, tentou redigir um diálogo, em que desenvolvia a defesa da comunidade de Platão até mesmo na questão do tratamento das esposas. Escreveu uma resposta ao Tiranicida de Luciano, em cuja argumentação quis ter-me como rival, para testar sua proficiência nesse tipo de escrita. More publicou sua Utopia para mostrar o que provoca o mal na vida das comunidades, tendo em vista particularmente a constituição inglesa, que conhece e entende muito bem. Escreveu o Livro II aos poucos e depois, quando viu que um outro era necessário, acrescentou o Livro I de improviso: daí uma certa desigualdade que se nota no estilo (Clarissimo Equiti Ulricho Hutteno. Epistolae. Allen [ed.]. Vol. 4. 1922. Epístola 999, tradução de Ana de Melo Franco). 
A partir deste texto erasmiano, distingue-se a prática da declamação renascentista como um exercício escrito em prosa e um meio de obtenção de um estilo próprio. Verifica-se ademais neste trecho, conforme consideramos anteriormente, um exemplo típico das relações entre os humanistas e o compartilhamento de prosas em gêneros recebidos da Antiguidade, entre os quais, a declamação com seu espaço significativo, praticado simultaneamente como exercício e divertimento.

Em epístola a Erasmo (26 de maio de 1520), cerca de três anos após a publicação da "Queixa da Paz”, More se reporta às declamações de Luís de Vives (Thomas More. Corr. 93/35). Destaca o modo como o discurso, que versava sobre temas de primeira ordem, utilizava-se do apelo à emoção a fim de que o leitor pudesse como que "ver" e "sentir" aspectos do que era tratado. A declamação, então, também é entendida como um modo de expressar e transmitir sentimento em relação a determinada causa situando-se como um discurso retórico que, sem desprezar as dimensões do lógos e do êthos, se dirige especialmente ao páthos, ao tocar as emoções do leitor. Tal troca epistolar entre More e Erasmo denota a clareza com a qual esses autores entendiam o papeis retóricos do ethos e do pathos e sua respectiva relevância na declamação.

\subsection{Classificação das declamações renascentistas}

Van der Poel (2007, p. 128-129), depois de apresentar duas formas nas quais as declamações escritas eram apresentadas durante o Renascimento (ou seja, as declamações destinadas à circulação em manuscrito para um círculo restrito de amigos, mas ainda assim escritas, como os "Tiranicidas" de More e Erasmo, e as demais, destinadas à publicação editorial), afirma que não há uma distinção essencial entre elas, mas que se pode observar que, no primeiro tipo, predominam os temas históricos, enquanto que, no segundo, dá-se uma renovação da antiga prática oratória com escritos de gênero deliberativo:

Um primeiro grupo constitui-se de declamações sobre temas históricos da Antiguidade ou sobre personagens célebres, que, acima de tudo, eram vistas como meros exercícios retóricos, mas, pela escolha do tema e do tratamento, devem ser interpretadas como discussões dissimuladas sobre temas contemporâneos, especialmente da natureza política. Então, como alguns discursos cerimoniais, certas declamações podem ser categorizadas como parcialmente "clássicas" e parcialmente "modernas". Exemplos são as declamações sobre o tiranicida de Tomas More (1478-1535), escrita em resposta à declamação de Luciano em defesa do tiranicida (Tyrannicida), ou as 
cinco declamações de Vives, as Declamationes Syllanae (1520), na qual os políticos romanos argumentam a favor e contra a retenção do poder pelo ditador de Roma, enquanto Sula apresenta seu discurso de abdicação. Finalmente, há um grupo de orações ou declamações entre a categoria de discursos não escritos para a performance, mas para a publicação exclusiva em forma impressa, que a meu ver pode ser considerada completamente como "moderna". [...] Seus autores claramente tem a ambição da prática da verdadeira retórica de Cícero e Quintiliano, a quem atribuem um papel importante para o orador na prática do discurso público na esfera civil [...] Quando algum humanista toma a pena para escrever um discurso, anunciado explicitamente como retórico (oração, declamação, elogio ou outro tipo de denominação retórica), é provável que ele esteja apresentando sua opinião sobre um tema que ele considera relevante para a sociedade como um todo e apresentando seu ponto de vista com especial assentimento e convicção (Van der Poel, 2007, p. 128-129).

Segundo o argumento de Connolly (2009, p. 139), as fontes das antigas declamações, inclusive das gregas, eram, segundo o já citado elenco de temas proposto por Aristóteles, as causas políticas, as quais discutiam a paz e a guerra, a guerra civil, os impostos, as relações internacionais e outros temas políticos, todos do gênero deliberativo, e que não deixaram de estar em voga no Renascimento. Quando um rétor ou um declamador argumentava a favor da paz, discutiam-se alguns princípios que poderiam confrontar os tiranos de todos os tempos, como a liberdade, a virtude da lei e a paz (Ibid., p. 140). Estas faziam com que a declamação não fosse antiga ou moderna, mas, em um sentido ainda mais amplo e menos restritivo, quase atemporal, na medida em que eram valores que perpassavam várias épocas históricas, mas também se mantinha, em comum, uma espécie de tradição, dada a invenção e a imitação, ambas baseadas em padrões estabelecidos por autores antigos.

De fato, tanto o locutor de um exercício declamatório nos tempos do Império, quanto um humanista que escrevia sua "declamação" em que tocava pontos de interesse para a sociedade tinham em vista assuntos que chamariam a atenção dos seus ouvintes e que se mostrariam úteis (utilitas), conforme os princípios basilares do deliberativo.

Nesse sentido, verifica-se que, à semelhança das declamações romanas, que inseridas nas típicas atividades dos rétores, foram entendidas como ofensivas ao despotismo imperial, as declamações renascentistas abordavam temas úteis e muitas vezes polêmicos diante das autoridades. Já citamos acima a afirmação de Mack (2004, p. 261) segundo a qual "o renascimento da retórica clássica poderia ser caracterizado com três palavras: recuperação, adição e renovação". Se a recuperação é evidente com a retomada da antiga declamação, a adição (additon) e a renovação (change) dão-se justamente na atualização deste gênero em 
relação ao contexto histórico social no qual está inserido. Esta adaptação ao contexto era exigida tanto na chamada declamação que o autor denomina como "clássica" como na dita "moderna", uma vez que a audiência ou os leitores precisam ser convencidos segundo as paixões que lhes são sensíveis, conforme os argumentos que lhes são verossímeis e em concordância com sua compreensão da moral e dos costumes. A mudança se alinha à época, mas ela própria já era prevista pelos clássicos, de modo que é uma das características imprescindíveis para um discurso efetivamente persuasivo.

\subsection{Definições da declamação pelos renascentistas}

Consideramos anteriormente que a imitação do gênero da declamação nos primórdios do século XIV entre os humanistas do norte da Itália, das declamações de autores antigos que escreveram em grego e latim e a redescoberta do texto completo da Instituição Oratória de Quintiliano foram passos determinantes para a recepção da declamação feita por Erasmo. Chomarat (1981, p. 934) observa que os princípios teóricos clássicos da declamação chegaram ao Renascimento por meio dos escritos desse autor romano. Sobretudo com Lourenço Valla, o orator era denominado como "aquele que fala diante de uma tribuna ou assembleia", e o rhetor, “é o professor de retórica". Já o declamador é

...aquele que, estudando com o rétor, executa uma causa fictícia diante dos alunos reunidos, a fim de poder, em seguida, exercitar-se nas causas reais. $\mathrm{O}$ rétor que, mesmo fora da escola, pratica esse gênero, seja para exercitar outras pessoas, seja para exercitar-se a si mesmo, é denominado declamador (Valla. Elegâncias da língua latina. IV, 81).

Um contemporâneo de Erasmo, Henricus Cornelius Agrippa (1486-1535), que também produziu diversas declamações com temas semelhantes às erasmianas, assim conceitua a declamação:

por conseguinte, a declamação não julga, não dogmatiza, mas (...) fala por vezes como brincadeira, por vezes seriamente, às vezes com falsidade, às vezes com rigor; ela fala às vezes segundo meu próprio pensamento, às vezes segundo o pensamento de outrem; ela propõe verdades, falsidades, afirmações dúbias; (...) ela aduz a muitos argumentos sem valor (Cornelius Agrippa. Apologia adversus calumnias propter declamationem de Vanitate scientiarum. 1533). (apud Chomarat, 1981, p. 941).

Como vimos, tanto na definição de Valla como na de Agripa, permanecem duas características principais da declamação tal como fora entendida e praticada pelos autores antigos, especialmente Quintiliano, ou seja, trata-se de um exercício de elocutio e de um 
discurso fictício. Van der Poel (1997, p. 128-129) comenta que a definição de Agripa e dos humanistas em geral, inclusive de Erasmo, era a de um discurso de uma personagem fictícia. Mas, devido ao fato de que a declamação no período renascentista não tem mais a finalidade de ser meramente um exercício escolar e é praticada de forma escrita, Surtz (1957, p. 9) propõe que esta seja "uma composição escrita para o divertimento e para o prazer a fim de exercitar o talento nativo do autor e desenvolver seu poder literário".

\subsection{Conclusões do capítulo}

O presente capítulo teve a finalidade de expor alguns elementos sobre a recepção do gênero da declamação entre os humanistas. As declamações antigas se classificam de dois modos: eram privadas ou públicas (Kennedy, 1980, p. 103), isto é, não podem ser reduzidas somente a exercícios escolares, executados para a educação dos jovens oradores, mas tinham também um caráter performático, uma vez que costumavam ser praticadas por adultos com a finalidade de produzir deleite em reuniões sociais ou como tirocínios privados da eloquência (Schwartz, 2004, p. 68-69; Edward, 1928, p. xiv; Fairweather, 1981, p. 544). Contudo, Winterbottom (1980, p. 13), baseado em um texto de Quintiliano que trata do panegírico e do demosntrativo no contexto das declamações escolares (Instituição Oratória, II, 10, 11), afirma que algumas das declamações públicas eram por assim dizer, do epidítico, uma vez que visavam muitas vezes a estabelecer um elogio ou um vitupério, ao contrário das demais declamações “didáticas”. Baseado em Quintiliano, Winterbottom (1980, p. 26-27) reconhece o gênero judiciário como a principal finalidade da declamação, mas distingue na Controuersiae 2,7,6-9 de Sêneca, o Rétor, elementos característicos do gênero epidítico, demonstrando que o elogio e o vitupério também eram recursos retóricos correntes nas declamações de gênero judicial, pois muitas vezes era necessário qualificar a vítima ou uma testemunha através do elogio e desqualificar o réu ou uma testemunha através do vitupério.

Como vimos, o próprio Cícero afirmou declamar entre os seus amigos e familiares justamente para exercitar-se para os momentos mais importantes de sua ação política. $\mathrm{Na}$ Roma Imperial, difundiu-se na alta sociedade o costume de fazê-lo, de modo que a historiografia romana registrou na vida de alguns imperadores, ao longo do período contemplado, o costume de executar declamações (Schwartz, 2004, p. 68-69). Embora se possa discutir acerca da real historicidade desses relatos, pode-se dizer que a atribuição da 
prática declamatória pelos textos historiográficos a respeito da vida dos imperadores denota que essa prática gozava de certo prestígio, ao menos no período imperial, muito embora alguns textos critiquem os declamadores e suas performances. $\mathrm{O}$ próprio fato de dedicar espaço para crítica escrita numa época em que a produção de texto não era tão simples atesta o alcance que a declamação teve na sociedade romana.

Verificou-se que a recepção e a prática do gênero no Renascimento teve seu início no norte da Itália e coincidiram - ou foram causadas - com a redescoberta de manuscritos, suas traduções e reedições impressas de algumas das obras retóricas mais importantes e que tratavam sobre a declamação de autores como Cícero, Quintiliano e Sêneca. Vários humanistas, como Salutati e Valla (situados no século XV) e Erasmo de Rotterdam, Thomas More, Cornélio Agrippa, entre outros cuja atividade pública data da primeira metade do século XVI, produziram declamações escritas como exercício, o que é característico desse tempo e o que as diferencia da Antiguidade; vimos ainda que as definições das características essenciais da declamação propostas por Valla e Agripa são concordes com as antigas, no sentido de afirmá-la como exercício retórico escrito de um discurso fíctício sobre temas suasórios ou epidíticos, com ao menos duas finalidades explícitas: divertir, através de formas e referências que provocam o riso, e instruir, através da persuasão e da defesa de valores éticos abandonados ou marginalizados pela sociedade. 


\section{CAPÍTULO 2 - A DECLAMAÇÃO ERASMIANA E A QUEIXA DA PAZ}

O presente capítulo tem como finalidade apresentar agumas características gerais da declamação erasmiana, tais como suas definições, temas, classificações e o contato de Erasmo com outras declamações de seu tempo. Além disso, procura salientar os argumentos a favor e contra a classificação da "Queixa da Paz" enquanto pertencente a esse gênero em uma comparação com algumas das declamações do final do período republicano e do início do império.

\subsection{Definições erasmianas}

A definição de declamação proposta por Erasmo abrange a proposição principal das definições de Valla e Agripa, ou seja, do exercício-fictício. O holandês distingue entre declamador, rétor e orador, na sua paráfrase ao Elegantias de Valla: "declamador é aquele que, a sós ou na escola de retórica, defende uma causa fictícia, a fim de melhor executar uma causa verdadeira. Declamar é exercitar-se em um discurso sobre um tema fictício" (Opera Omnia Erasmi. I-4, 11. 313.923). Erasmo parecia estar bem ciente dos limites e das características essenciais do gênero, como se depreende, por exemplo, de uma citação extraída de seus Adágios, a qual não deixa de ser, também, uma autocrítica, feita a partir da classificação da declamação presente em um escrito de Jerônimo (Erasmo. Adagia. 2500. III, V, 100. Nec aures habeo nec tango). Tal comentário aparece na explicação do adágio 100, cujo significado pode ser entendido como "não tenho ouvidos, nem toco" e se insere no contexto de alguém que pegou algo de outro e, diante do protesto deste, dissimula a posse. Ao explicar o provérbio, o holandês cita uma epístola que Jerônimo qualifica como declamação (Epístola 117, 12), cujo tema seria sobre a reconciliação de uma mãe com sua filha. Justamente ao denominar como tal esse escrito, e talvez percebendo que a causa não é deliberativa nem judicial, nem mesmo um elogio ou sequer um caso fictício, mas tendo permanecido o caráter de exercício, Erasmo mantém a denominação de declamação, talvez por respeito à autoridade do Padre da Igreja que também era rétor, muito embora esta classificação possa ser facilmente contestada. Erasmo, portanto, estaria consciente de que a declamação tem seus limites próprios e que Jerônimo poderia ser criticado ao extrapolá-los, ao denominar assim neste texto em particular. 
Com base na definição erasmiana, Akkerman (1995, p. 53-54) procura diferenciar a declamação da oração: "Em um sentido mais restrito, oratio é um discurso que é, na verdade, realizado em resposta a um evento social ou cerimonial, e declamação, um exercício fictício que se executa na escola ou a sós". Erasmo também entendia como declamação "um tema imaginário que se trata a favor e contra, a fim de exercitar a eloquência”. Essa definição, segundo Chomarat (1981, p. 937), seria "a que mais distingue a declamação da 'determinação' dos teólogos escolásticos", conforme consta em várias passagens do "Sobre a língua" (De língua): o primeiro equívoco estilístico mencionado por ele seria o fato de atribuir palavras ou expressões que inflam a importância das coisas de modo que o tom do discurso solene, inclusive na declamação, não condiz com o assunto tratado. Assim, este torna-se tedioso, falso e inclusive ridículo. Tal modo de proceder, o holandês o entende como uma "tagarelice declamatória" que corrompe a verdadeira finalidade da eloquência. Embora afirmasse que, para julgar as declamações, "não se deve considerar a verdade objetiva das matérias, mas o talento natural e o poder persuasivo do escritor" (Apologia Adversus Monachos Quosdam Hispanos, Opera, IX, 1089), estava ciente do poder persuasivo deste gênero e dos incômodos que seu uso para fins políticos poderia gerar. Por isso, Erasmo utilizou-se dele ao tratar sobre assuntos políticos nem um pouco unânimes, como é o caso da querela da paz e da guerra.

Por fim, há referências à declamação também no Diálogo Ciceroniano. Nosópono, o ciceroniano inveterado, que defendia a imitação restrita dos escritos de Marco Túlio, afirmava praticar com alegria (feliciter) a declamação (Erasmo. Ciceroniano. 644[21]), mas recusava a sugestão de Buléforo de receber as contribuições de Quintiliano a esse gênero (Erasmo. Ciceroniano. 657[35]). Deste trecho, em contraste com o que defendiam os chamados ciceronianos, se percebe que a declamação erasmiana não se restringe à imitação de Cícero, mas era um gênero que se fundamentava essencialmente na recepção de outros autores que praticaram ou teorizaram acerca deste gênero com maior ênfase do que ele, tais como os declamadores latinos e gregos do período imperial: Sêneca, Quintiliano, Plutarco, Luciano, Libânio, entre outros. Erasmo, aliás, sem distinguir a autenticidade da atribuição de autoria das "Declamações Maiores" e "Menores" a Quintiliano, elogiava no "Sobre a abundância" (De copia, 204-205 [246-247]) “as descrições das coisas" apontando este elemento localizado geralmente logo após o proêmio da declamação como um artifício para a captação da benevolência e da atenção do leitor. Por outro lado, no Cap. 12 [504-507], analisa o uso que 
Cícero fazia do termo declamare, em passagem que evoca o livro II da "Retórica" aristotélica, ao relacioná-lo com a caracterização adequada ou apropriada de cada personagem de acordo com a sua idade. Entre os vários elementos a serem exercitados com a prática declamatória, Erasmo apresenta em seu "Plano de Estudos" o êthos representado nas prosopopeias como um dos pontos fundamentais, as descrições dos lugares, do tempo e das coisas, assim como a dequação das personificações à idade (jovens ou idosos) ou à profissão (prostitutas, soldados), entre outros (Opera Omnia. I-II. 143[1-9], 1971, p. 143).

\subsection{Temas}

Erasmo é muito explícito ao tratar da declamação e dos exercícios (note-se o uso de progymnasmata) em seu De ratione. Para ele, há necessidade de tratar de temas atuais, úteis para a sociedade (respublica), que não tenham somente a simples finalidade de exercício retórico ou de rememoração de dados mitológicos e históricos, nem mesmo meras elucubrações inúteis da dialética atribuída pelos humanistas aos escolásticos. Neste sentido, a declamação erasmiana é prática, visa influenciar o leitor, educá-lo não somente no sentido de aplicar na vida cotidiana os ditames da retórica antiga, mas também de instruí-lo em valores como a justiça, a paz, a coerência dos costumes e o combate aos hábitos considerados ridículos e que se fundamentavam numa tradição cristã teologicamente mal entendida. Se, por um lado, algumas partes do discurso provocam reflexões sérias, outras partes, porém, apesar da gravidade do assunto (por exemplo, quando se fala de paz e guerra), deleitam o leitor, sem deixar de ser útil, por ser pertencente ao gênero deliberativo:

Desse modo, era necessário que este jogo [elocutório] fosse apresentado de modo elegante, para que o jovem se exercitasse nas escolas através das declamações, muito embora Quintiliano tivesse com razão preceituado que a simulação da declamação acontecesse de uma forma mais próxima possível com as verdadeiras ações, pois os temas a se declamar costumavam ser escolhidos entre as fábulas dos poetas e não entre as coisas verossímeis. Com efeito, aqueles exercícios são importantes para os jovens, porque tem o objetivo de instrui-los, sobretudo, quando o argumento é tirado da História e é adaptado às palavras e às sentenças daqueles tempos; contudo, será ainda mais instrutivo atuar sobre as causas verdadeiras, que tratam de questões envoltas em circunstâncias do tempo presente, como se alguém as desenvolvesse, para que se aperfeiçoe a república... (Erasmo. De ratione Studii. Desiderii Erasmi Opera Omnia. I-II, 1971, p. 695[28-33] - p. 696[1-2]).

Quando Erasmo menciona que os "temas a se declamar costumavam ser escolhidos dentre as fábulas dos poetas e não entre as coisas verossímeis”, podemos entender que o autor 
visava um discurso que não fosse somente uma espécie de reprodução saudosa dos antigos gêneros discursivos gregos e romanos, mas uma discussão incisiva sobre os costumes das pessoas de seu tempo. Quando pertencente ao deliberativo, abordaria temas que seriam pertinentes para a sociedade, como, aliás, o era, a polêmica a respeito dos benefícios da paz e dos malefícios da guerra inclusive sob o aspecto individual. A Paz apresenta argumentos práticos contra a guerra como as dificuldades para o comércio, os gastos com mercenários e armamentos e, inclusive, a insegurança provocada pelo acúmulo destes em relação ao patrimônio dos cidadãos e possíveis abusos contra a honra das mulheres.

Neste sentido, se as declamações erasmianas tratavam dos temas mais diversos, tais como a guerra, a paz, a infância, a loucura, o matrimônio, a vida monástica e a medicina, entre outros. Nelas, era corrente o elogio e o vitupério, seja nos escritos em que predominava o Encomium, seja nos deliberativos, abordavam-se posições consideradas absolutas ou irrefutáveis por parte de teólogos e filósofos. No lugar de privilegiar a lógica e o exaurimento dos argumentos como é próprio da dialética, considerava esse temas, porém, de modo a privilegiar o que era útil ao ser humano, e afrontava os argumentos contrários aos seus ideais através da retórica. Erasmo não negava a verdade, mas valorizava o que favorecia a humanidade ulizando-se da retórica para uma finalidade que considerava justa. Erasmo estava ciente de que "não existe nada tão bom por natureza que não possa ser distorcido por um declamador astuto" (Liber utilissimus de Conscribendis Epistolis, 1670, p. 267), mas estava certo também de que o declamador competente deveria primiar pela justiça e pela utilidade, mais do que pela mera busca da verdade abstrata e muitas vezes inútil para o bem comum, muito embora fosse conveniente para os propugnadores da guerra.

O caso concreto das discussões sobre a guerra justa - tão defendida e inclusive promovida por teólogos alinhados aos interesses temporais de conquistas feudais ou mesmo das guerras contra o islã - era um tema polêmico, uma vez que nem sempre a paz era do convinha aos príncipes, inclusive neste contubardo início do século XVI. Em outras palavras, segundo esse trecho do texto supracitado, o declamador astuto tem o poder de reunir a favor do seu argumento uma apresentação da realidade afim à sua causa. Os argumentos eram alinhavados em vista da finalidade prevista e poderiam distorcer "verdades" incontestes. Trata-se não somente da possibilidade de selecionar e dispor de argumentos, mas de um modo de apresentar que rompe ou desconstrói paradigmas a fim de construir outros, talvez 
esquecidos ou postos de lado, como o é no caso em questão, a causa da paz e oposição à doutrina da guerra justa.

Erasmo advoga pela paz e o faz como cristão, mas não se apresenta, ao menos no texto da "Queixa da Paz", como um filósofo ou um teólogo compromissado com o que chama de verdade a ponto de apresentar os dois lados da questão, ou seja, os argumentos a favor e contra a paz e a guerra, mas defendia aquela sem considerar as objeções contra o irenismo, dispondo sua razões com a finalidade de fazer bem ao auditório no sentido de instruí-lo com valores éticos, como é o caso daqueles que fundamentam a opções pela paz. Neste sentido, Erasmo não seria um sofista que alinha argumentos contra a guerra, mas um cético em relação à sua eficácia na resolução dos problemas. Acreditava que a concórdia era mais adequada e duradoura para a resolução de qualquer espécie de conflito em contraste com a guerra, uma espécie de multiplicadora dos males.

Convém, então, demonstrar as incoerências dos propugnadores da guerra, apontando os malefícios desconsiderados pelos que defendiam o princípio da guerra justa, conforme estudaremos, ao caracterizar a Paz como sábia e teóloga no último capítulo da presente dissertação. Essa afirmativa não nega, porém, uma espécie de outra finalidade pedagógica da declamação erasmiana, não menos relevante que a primeira, como consta em uma passagem da epístola a Ulrico de Hutten. Nesta, ao comentar a declamação sobre o "Tiranicida" de Luciano e a "Utopia" de More, Erasmo estava ciente da finalidade de deleitar ou comprazer própria ao gênero, conforme o texto supracitado, no qual mencionada o percurso da formação retórica do seu amigo More.

Convém notar que as declamações humanistas, de modo análogo ao que se verificou naquelas praticadas em círculos de adultos e amigos no período republicano e imperial, também visavam ao deleite, situando-se então como uma autêntica produção artística. Desse modo, não parece absurdo afirmar que a declamação, segundo a concepção erasmiana, tem um a dupla finalidade formativa (ética, situada nos valores, e retórica, como aplicação prática de princípios em um discurso concreto), com toda a seriedade imposta pela gravidade dos temas, mas com o intuito de não menosprezar a finalidade propriamente artística, de deleitar ou divertir o leitor. Nesse ponto, verifica-se a qualidade das declamações erasmianas que sabem ser sérias, jogando com temas graves, sem deixar de formar os valores considerados 
humanos, justos e úteis. Desse modo, o roterdamês parece evocar o célebre preceito horaciano: unir o útil ao agradável (utile dulci).

\subsection{Contato de Erasmo com declamações precedentes}

Erasmo teve contato direto com as declamações e teorizações sobre este gênero escritas em grego ou em latim, por Isócrates, Plutarco, Luciano e Libânio. O próprio holandês atuou como editor e tradutor de algumas delas em um período imediatamente anterior à publicação da "Queixa da Paz" em 1517, entre as quais se destacam aquelas elencadas por Rummel (1985, p. 171-172) e cujos fac-símiles estão disponíveis para consulta on-line no site oficial $^{8}$ da Biblioteca Nacional da França e que também foram reeditadas na edição crítica da obra de Erasmo.

\subsubsection{Isócrates}

De fato, Erasmo, durante sua juventude, traduziu alguns panegíricos de Isócrates, os pertencentes ao gênero demonstrativo, sobretudo no tocante à vituperação e ao elogio, a ponto de publicar o Ad Nicolem juntamente com a "Instituição do Príncipe Cristão", em Basileia, no ano de $1516 .{ }^{9}$ Um princípio pedagógico atribuído por Erasmo a Isócrates, citado no "Sobre os meninos" (De pueris) e que parece se coadunar com as duas finalidades pedagógicas da declamação (ética e retórica), é justamente o princípio segundo o qual o recurso ao páthos próprio do exercício retórico, predispõe o aluno a aprender quando seu afeto é movido ao conteúdo proposto. Trata-se do aprendizado através do delectare, ou seja, do prazer que é inerente à declamação de alto nível. Os discursos escritos então neste gênero teriam o poder de fazer com que o leitor amasse os valores éticos e os recursos retóricos apresentados durante o discurso. A vituperação também age sobre a vontade do aluno, uma vez que produz a repulsa às atitudes e aos princípios não considerados éticos pelo retórico, e a ridicularização destes no interior do discurso visa, então, desconstruir a pretensa legitimidade de tais ações que muitas vezes se atribuíam à tradição ou à justiça, como é o caso da guerra.

${ }^{8}$ Disponível em: http://www.bnf.fr/fr/acc/x.accueil.html Acesso: 17 nov. 2015.

${ }^{9}$ Além do panegírico de Isócrates e das declamações de Luciano e Libânio, diretamente relacionadas com as declamações erasmianas, Erasmo também editou outras obras no mesmo decênio que a Queixa da Paz, tal como a Institutiones grammaticae, uma gramática grega escrita no século XV, escrita por Teodoro de Gaza e publicada em dois volumes em Lovaina (1516 e 1518) e as traduções de Rodolfo Agrícola de Isócrates (Ad Demonicum) publicada na mesma cidade em 1517. 


\subsubsection{Plutarco}

A influência de Isócrates é reduzida ao comparar-se com aquela de Plutarco. Na epístola a Thomas Grey (Epístola 64, Paris, agosto de 1497, 1. 81, Allen, 1974, p. 137), Erasmo já mencionava a personagem Gryllard, o que denota seu acesso à Moralia (985D992A) e a alguns discursos em grego, entre os quais, aqueles que são explicitamente classificados como declamações. O mais significativo deles é, sem dúvida, o "Sobre a educação dos meninos" que influenciou diretamente o "Sobre os meninos" do roterdamês. Não sem razão, discursos de Plutarco foram vertidos por ele ao latim e editados em 1515 , cerca de dois anos antes da publicação da "Queixa da Paz" (1517).

\subsubsection{Luciano}

Segundo Boulet (2015, p. 69), em recente estudo sobre as declamações renascentistas,

Ao lado de Plutarco, Luciano parece um autor particularmente interessante no movimento que leva de Aristóteles a Cícero e de Erasmo a Boécio. Ambos os autores são constantemente mencionados, direta ou indiretamente, nas declamações que nos interessam; eles eram constantemente traduzidos e comentados. Eles são exemplos, para os autores que nós estudaremos, considerados como guias e modelos. Certo número de tratados de Luciano foi traduzido para o latim por More e quatro por Erasmo.

O roterdamês não se debruçou em escritos de temas políticos ou naqueles atribuídos ao gênero judiciário, mas, além dos escritos no gênero demonstrativo, dedicou-se ao estudo e à tradução de várias declamações, como as de Luciano (Rummel,1985, p. 21).

Erasmo dedicou-se de modo especial ao esforço de traduzir do grego para o latim diversas obras de Luciano (125-180 d. C.), rétor que se destacou por suas obras satíricas, conforme o próprio holandês afirma na "Epístola a João Botzheim". ${ }^{10}$ Luciano foi ainda um dos autores explicitamente prestigiado no "Plano de Estudos" erasmiano, muito embora alguns autores quinhentistas criticassem o valor de suas obras, conforme se lê na introdução à tradução ao "Timeu" de Platão realizada por Erasmo (Robinson, 1969, p. 365). Dentre as traduções das declamações de Luciano, realizadas e publicadas em dois volumes ao longo do

\footnotetext{
${ }^{10}$ Erasmo enumera: As saturnais; Cronosolon; Algumas epístolas saturnais; Sobre o luto; Icaromenipo; Toxaris; $O$ pseudomante; $O$ sonho ou o galo; Tímon; $O$ abdicante; o Tiranicida; Sobre aqueles que são conduzidos aos palácios dos poderosos por mercê.
} 
ano de 1506, algumas foram publicadas sob o título de Luciani compluria opuscula (Toxaris, Tyrannicida, Timon, Gallus, De mercede conductis e Longaevi); e outra parte foi dada a conhecer com o título de Opuscula (Dialogi Mortuorum, Dialogi Deorum, Dialogi naturam, Hercules, Eunuchus, De Sacrificiis e Convivium). Erasmo retornou, entre os anos de 1511 e 1512, à tradução e edição de um terceiro grupo de escritos de Luciano (Icaromenippus, Saturnalia, Astrologia, Cronosolon, Espistolae Saturnale, De luctu e Abdicatus), publicados com as traduções anteriores sob o título de "Luciani Erasmo interprete dialogi..." em Paris, no ano de 1514. Essas obras já foram republicadas pela edição crítica de Amsterdam (1969atual). Thompson (1974, p. 92) reafirma o consenso dos pesquisadores acerca da influência do estilo das declamações de Luciano sobre as erasmianas, entre outros fatores pelo recurso à ironia, o sarcasmo elegante e a forma de ridicularizar costumes sociais incoerentes ou supersticiosos, conforme escreveu More, que atribuiu ao holandês seu contato com as declamações lucianescas. Aliás, um dos tópos da primeira parte da "Queixa da Paz" reafirma justamente alguns dos princípios atribuídos por Erasmo a Luciano na epístola introdutória ao "Sobre a Língua", como é o caso da comparação dos animais com o homem em tom de superioridade, justamente pelo fato de que, embora sejam tidos como irracionais, não se inferiorizam ao homem subjugado pelas paixões e pelos vis interesses, pois a troca de lugar entre homem e animal para desnudar a sociedade é um lugar comum da sátira lucianesca (Erasmo. Epístola a Cristóvão de Schiidlovietz, p. 19, 11. 9-13). Para Erasmo, o grande mérito dos diálogos de Luciano era fazer com que os mais jovens se deleitassem com o estilo e a língua (De conscribendis epistolis, I, 353B). Tal afirmativa ainda se verifica no "Sobre a abundância", no qual não se abstém de elogiar a capacidade descritiva do caráter viril realizada por Luciano em Hamônidas (De copia. II, 198, 11. 51-54-70-75).

\subsubsection{Libânio}

Quanto a Libânio (314-394 d. C.), filósofo e professor de retórica que escreveu em grego, Erasmo prefaciou a tradução da Declamatiuncula versa e graeco Libanio, cum thematis aliquot versis, que foi publicada sob o título de Libanii aliquot declamatiuncula, em 1503. Essas declamações merecem destaque dentro da obra de Erasmo e do Projeto Humanista (Rummel,1985, p. 21), por assim dizer, de recuperação dos autores grecoromanos, uma vez que o próprio Libânio teve inclusive parte de sua formação realizada na 
Grécia, tendo facilitado acesso a autores gregos antigos apesar da dificuldade de transmissão e leitura de textos inclusive na atiguidade tardia.

Sua atividade como rétor, inclusive participando de competições públicas, foi realizada junto aos imperadores que visavam a uma recuperação da antiga religião romana. Estes estavam em franco antagonismo com os cristãos, que, por sua vez, tentavam suprimir a antiga religião e a própria mitologia contida nas tradições de escritos greco-romanos, consideradas meros rituais mágicos que prejudicavam a fé cristã (Williams, 2009, p. 420). Embora as declamações de Libânio fossem datadas da era cristã, tinham, talvez, a preferência de Erasmo por portarem relevantes elementos da retórica clássica: segundo Kennedy (1983,162-163), tais discursos se diferenciavam dos antigos, entre os quais predominavam os temas judiciais e deliberativos, ao apresentarem principalmente temas mitológicos ou históricos gregos com a finalidade de discutir assuntos pertinentes para o seu tempo.

Libânio escreveu cerca de sessenta e quatro orações, dentre as quais muitas (cf. orações 48, 49 e 50) possuem temas deliberativos, em razão de sua própria atividade no âmbito político. Outro atributo de suas declamações é o fato de iniciar algumas delas com narrativas (katastasis), o que foi adotado por Erasmo em muitas de suas declamações. Em Erasmo, a Loucura e a Paz, por exemplo, não estabelecem uma narrativa em terceira pessoa, mas se caracterizam na abertura dos seus discursos através de uma locução direta. Libânio, contudo, se mostrava coerente com os manuais antigos de retórica que apresentavam a declamação enquanto exercício que defendia os dois lados de uma questão, pois muitas das suas declamações eram seguidas de uma ou várias antitheses, finalizadas por um epilogo (Williams, 2009, p. 424). Tal princípio não era seguido por Erasmo, que apresentava somente um lado da questão.

Convém salientar o fato de que uma das declamações de Libânio traduzidas por Erasmo tem justamente uma personagem feminina como sujeito ou remetente do discurso: Medeia. É bastante problemático comparar a Paz de Erasmo à Medeia dos clássicos, mas ainda assim verifica-se alguns traços de semelhança entre aquela mãe indignada pela morte dos filhos e que se apresenta como vítima. Há algumas passagens das declamações erasmianas nas quais a Paz demonstra sua indignação para os propugnadores da guerra que maltratavam os mortais a quem esta dedicou seus cuidados maternais. Note-se que a Paz, como veremos mais detidamente nos último capítulo da presente dissertação, invoca, em seu 
caráter feminino e maternal, as injustiças feitas contra as vítimas da guerra, a quem trata como verdadeiros filhos.

\subsection{Elenco das declamações de Erasmo}

Segundo Chomarat, as obras do gênero declamação na obra de Erasmo podem ser classificadas em duas categorias: primeiro, as declamações em sentido restrito, que listaremos abaixo; e, em seguida, as obras que contém elementos essenciais do gênero, sem, no entanto, receberem esta denominação. Muito embora Erasmo tivesse afirmado a dificuldade de delinear os limites entre a declamação e o diálogo, nota-se que possuía noções claras a respeito dos gêneros retóricos e suas subespécies, como descreve no Brevissima Confidendarum Epistolarum Formula acerca do deliberatiuum genus no contexto epistolar, mas que, por analogia, também se aplica a uma declamação de espécie deliberativa, e às declamações de elogio e vitupério, pertencentes ao gênero demonstrativo:

Então passemos ao gênero deliberativo, ocorrente em muitas espécies de epístolas: há epístolas suasórias e dissuasórias, exortatórias, petições, monitórias, as quais depois serão consideradas em sua ordem. Em primeiro lugar, deve-se definir no gênero deliberativo, que pode ser chamado de suasório, a utilidade e a honestidade. Quando chamamos algo de útil, também queremos denominar como honesto; quando não se pode dizer que é útil, igualmente não pode ser honesto. Porque nesse gênero deve-se maximamente esperar por essa utilidade, que está conjugada com a honestidade, sem as quais não podemos suadir, persuadir, dissuadir, exortar, desencorajar, pedir, aconselhar, nem direcionar (como assim disseram) todas as flechas do estilo ao alvo (Erasmo. Brevissima maximaque compendiaria confidendarum epistolarum formula. Paris: Apud Christianum Wechelum, 1551, p. 13).

De modo análogo, nos textos já citados de Quintiliano e Erasmo acerca da semelhança da declamação com o diálogo, Chomarat (1981, p. 932) reconhece a dificuldade em diferenciar uma declamação de uma oratio, como é o caso do "Manual do soldado cristão" (Enchiridion militis christiani), ou mesmo com uma diatribe, segundo a denominação do próprio Erasmo (Rummel, 1995, p. 60), como se verifica no "Sobre olivre arbítrio" (De libero arbítrio), a ponto de Chomarat (1981, p. 932) denominá-los “quasi-déclamations”, ou seja, obras que contém um dos elementos essenciais da declamação: a prosopopeia. Outra obra erasmiana não citada pelo estudioso francês constituída em estrutura de diálogo merece destaque especial, uma vez que, no caso do "Sobre o livre arbítrio", além de outras personagens, Erasmo entra no diálogo ao atribuir discursos ao seu próprio nome. Mas a 
grande objeção para sua inserção no gênero é o fato de não cumprir o quesito de que o texto deve simular uma causa fictícia.

Baseando-se na epístola de Erasmo a Botzheim, é possível estabelecer o elencode onze declamações escritas e publicadas pelo holandês e que se conservaram:

1. Elogio da vida monástica;

2. Resposta ao bispo;

3. Louvor e vituperação do matrimônio;

4. Elogio da medicina;

5. Contra o tiranicida;

6. Antibárbaros;

7. Sobre o desprezo do mundo; ${ }^{11}$

8. Sobre a prematura morte do filho;

9. Sobre os meninos;

10. Elogio da Loucura;

11. Queixa da Paz;

Chomarat (1981, p. 932) apresenta dois possíveis títulos de declamações compostas por Erasmo cujos textos foram perdidos: primeiro, "Vitupério à vida dos monges", que teria sido escrita em Bolonha, entre 1506 e 1507; e duas declamações com argumentações mutuamente opostas sobre a guerra do Papado contra Veneza, presumivelmente escrita em Bolonha, em 1508. Dada a temática, os argumentos descritos neste texto provavelmente estão presentes na "Queixa da Paz" e no "A guerra é doce para os inexperientes". Erasmo também mencionou em epístola datada de 1509 e enviada de Paris a intenção de escrever duas declamações (Encomium naturae e Encomium gratiae), que foram sugeridas por ocasião da redação do "Elogio da Loucura". 12

\footnotetext{
${ }^{11}$ Essa obra foi curiosamente classificada pelo próprio Erasmo como uma epístola declamatória suasória.

${ }^{12}$ Ainda segundo Chomarat (1981, p. 934), grande parte das declamações de Erasmo foram escritas por pedido "formal" de alguém que lhe era próximo (Laus vitae monasticae, Encomium artis medicae, Contra tyrannidam, as duas declamações perdidas escritas em Roma, De pueris e Querela Pacis) ou para seus alunos (Episcopi Responsio, Laus ac vituperatio matrimonii e De morte filii praemature praerepti), como modelos práticos dos conselhos teóricos do De Copia (Chomarat, 1981, p. 935). Esse último grupo pode caber na definição de declamação como exercício escolar. Quanto àquelas feitas a pedidos, com evidente finalidade política (como a Queixa da Paz) ou laudatória, ou ainda, como publicações que visavam debater assuntos literários e que ilustravam os conselhos contidos no De Copia (Chomarat, 1981, p. 934).
} 


\title{
2.5 Classificação das declamações erasmianas
}

Van der Poel (2007, p. 129) classifica as declamações erasmianas em três espécies: pedagógicas, moralizantes e políticas.

\begin{abstract}
Nas numerosas declamações de Erasmo sobre matérias morais e pedagógicas, como também nas de assunto político, como o Encomium moriae, De pueris instituendis, Querela Pacis, e também o Encomium matrimonii, também encontramos referências típicas do vir bonus dicendi peritus. Suas declamações são manifestamente discursos escritos, nos quais não somente critica as condições da sociedade e do interior da Igreja que ele acha repreensível, mas nas quais também defende suas próprias ideias de sociedade cristã civilizada, ideal que prova ser, na verdade, bastante controverso. Na sua carta a João Botzheim, de 1523, Erasmo assume que o propósito de muitas de suas declamações pertinent ad institutionem vitae (visam a prover a instrução do modo de viver).
\end{abstract}

Desse modo, cabe às declamações deliberativas, e inclusive algumas laudatórias, a finalidade de mouere, mas em Erasmo há uma especificidade, pois o movimento da vontade do seu interlocutor é impulsionado pela tomada de atitudes em conformidade com valores humanos considerados bons. Nesse sentido apresenta uma finalidade pedagógica através da defesa de princípios éticos edificantes. O que também é uma forma de suadere, uma vez que a declamação erasmiana entendida como um discurso que não defende as duas partes de uma causa, mas opta por uma delas considerada melhor, leva a escolher uma entre as opções disponíveis. Desse modo, o discurso tem um objetivo bem determinado, e o mouere e o suadere estão à disposição do declamador para sugerir ações consideradas úteis (conveniente) e honrosas (honestum).

De fato, segundo Tunberg (2006, p. 9), as obras de Erasmo, especialmente o "Elogio a Loucura" e a "Queixa da Paz", visam a indicar um caminho ético e se ocupam do modo de agir humano. Para Chomarat (1981, p. 937), o humanista visava a uma ação política marginal: “constituir-se propagandista de uma escolha política feita por outros a fim de exercer uma influência moral sobre a opinião ou sobre os governantes que o honram mais do que o escutam". O próprio Erasmo apontou essa intenção explicitamente, ao inserir várias de suas declamações, inclusive a que estudamos, no quarto volume da edição de suas obras completas, publicadas em sua vida, com o sugestivo título: "Obras que visam à instrução dos costumes" (Cantos, 2006, p. 285). Tal propósito é verificado por Tunberg (2006, p. 17), ao comentar a prosopopeia erasmiana da Paz: 
Nas declamações de Erasmo, não somente no que se refere ao Elogio da Loucura, mas também à Queixa da Paz, ambas apresentam uma noção vaga ou abstrata de uma espécie de mulher divina na qual se vê a capacidade de falar e apontar com o dedo de que maneiras certos costumes humanos devem ser emendados.

Corrigir os costumes é também tarefa do riso. No "Elogio da Loucura", o lado satírico é evidente. Na "Queixa da Paz”, Erasmo parece querer moralizar a sociedade não por meio da sátira mas, sobretudo, da ironia, da comparação entre o vício e a virtude, entre o belo e o feio. Trata-se do uso do elogio e do vitupério como instrumentos de moralização. Este recurso se insere em uma concepção estratégica ainda mais ampla de Erasmo, segundo a qual a educação nos clássicos seria um instrumento para a moralização da sociedade de caráter catequético, não para sua paganização. Para Sloane (2004, p. 112), predominavam no Renascimento duas formas de recepção dos clássicos: a primeira prezava os autores antigos como fontes do prazer da elocutio; e a segunda, como fonte de inspiração para a imitatio. Como vimos anteriormente, as declamações de Luciano, aos olhos de Erasmo e More realizavam tal propósito com excelência. No caso do "Elogio da Loucura", o recurso à sátira é evidente, mas não se deve deixar de observar tal aspecto nas demais declamações erasmianas, nas quais Margolin (1992, p. 911), ao comentar a "Queixa da Paz", notou diversos recursos retóricos, como "a ironia, mas com mais cólera, emoção e piedade em defesa do povo atingido pelos reveses da guerra". Dessa forma, pretende mostrar, em quatro seções de argumentos, a incoerência dos humanos que defendem a guerra, dos cristãos que guerreiam e dos príncipes que governam com base na guerra, e, sobretudo, a incongruência da missão clerical com o ofício das armas.

\subsection{Declamação escrita e integral}

A "Queixa da Paz" foi concebida em forma escrita, para ser publicada, e não há evidências de que existisse alguma espécie de actio das declamações de Erasmo ou de outro humanista, ou seja, de que elas fossem lidas em voz alta e na presença de uma audiência, ainda que em contexto familiar. Nesse aspecto, nota-se uma diferença fundamental entre esta declamação e muitas das declamações antigas, pois os humanistas não visavam mais ao deleite e à persuasão do seu público-alvo através da modulação da voz, mas concentravam sua atenção ao efeito agradável que a ordenação e a escolha adequada das palavras e aos diversos 
recursos retóricos poderiam causar em alguém que lia a obra na solidão em pronunciar em voz alta.

Contudo, o deleite produzido por um discurso no leitor solitário ou no ouvinte da assembleia pública ou de um contexto íntimo ou familiar não está localizado apenas na finalidade formal de que este teria sido escrito "para ser pronunciado" ou "para ser lido individualmente", mas sim na riqueza de figuras, nos jogos de palavras e imagens e nos diversos recursos que a retórica disponibiliza, de modo que a mera forma de veiculação, no sentido de que ele deve ser lido individualmente ou em público, não seria um fator suficiente para descaracterizar um gênero. Deve-se considerar que, primeiro, ainda que escrita, a declamação imitava a forma dos textos falados. Segundo, porque ainda se praticava muito a leitura pública. Talvez Erasmo não tenha ele mesmo lido seu texto em voz alta, mas é bem provável que círculos de amigos ou seguidores se reunissem para que um lesse para os outros os "lançamentos" do mestre.

\subsection{O público alvo e o contexto histórico}

Assim como ocorria na declamação antiga, a humanista tinha por audiência a elite letrada, capaz de ler latim com naturalidade a ponto de compreender as ironias, os sacarmos e as entrelinhas contidas nos textos erasmianos. Era esse público que se deleitava com os jogos e os exercícios declamatórios.

Tais recursos retóricos estavam inseridos também em um contexto político, de modo análogo à prática da declamação imperial, conforme já analisamos. Segundo evidências internas e externas, apontadas por Beauduin (1991, Introdução), essa obra foi escrita em Lovaina, Bélgica, em uma data e ocasião incerta não posterior a novembro de 1516, quando Erasmo "visitou a corte por ocasião de uma assembleia dos maiores príncipes da época" (Cantos, 2006, p. 23; Herding, 1977, p. 7) e estabeleceu contatos com pessoas influentes, como o Chanceler Montjoy (Erasmo. Ep. 516. Linhas 17-18. Carta a Pierre Gilles de 20 de janeiro de 1517, 1977, p. 187). A “Queixa da Paz” foi publicada no decorrer do ano de 1517, tendo sido dedicada ao Abade de Saint-Bertin, Antônio de Bergen. Note-se que Erasmo, entre os anos de 1515 e 1521 (Rummel, 1996, p. 243), era Conselheiro do Rei Carlos V (Herding, 1977, p. 8), da dinastia dos Habsburgos, Rei dos Países Baixos, terra de Erasmo, da Espanha, de Nápoles, Sicília e Jerusalém e Duque da Borgonha, cujo ducado haveria de ser anexado 
pela Espanha no dia 23 de janeiro de 1517 (Bataillon, 2007, p. 81). A partir de 1519, o Rei Carlos seria também o Imperador dos Romanos (1519-1558). A família dos Habsburgos, cujo centro de atividades era a Espanha, já era a mais poderosa dinastia europeia por volta da publicação da Queixa da Paz (1517). Bataillon (2007, p. 81), com base nas cartas de Erasmo, informa que, em virtude do cargo de conselheiro, este chegou a receber rendimentos espanhóis, mas não aceitou o bispado de Zaragoza nem mudar-se para a corte espanhola, a fim de evitar o ambiente dividido em facções e contaminado por posições políticas contrárias a seus próprios valores. Erasmo desculpou-se de aceitar a prebenda episcopal e passou a frequentar a Universidade de Lovaina, onde esteve mais assiduamente entre os anos de $1515 \mathrm{e}$ 1521 (Rummel, 1996, p. 243), dedicando-se ao estudo dos escritos bíblicos, não sem aproveitar os recursos da célebre biblioteca (Bataillon, 2007, p. 82). Essa foi a fase de sua vida que precedeu às mais acirradas controvérsias teológicas que aos poucos foram minando seu prestígio de preceptor da Europa. No ano de 1516, não seria exagero afirma que o holandês era o epicentro intelectual desse mundo fluente no latim. A situação dúbia em que se posicionou em relação ao cargo de conselheiro oferecido pelo rei não somente demonstra o prestígio e a influência dos seus escritos, mas também uma espécie de autonomia com a qual o escritor pretendia apresentar suas ideias, inclusive a despeito de prebendas e posições políticas.

Segundo Herding (1977, p. 13), como evento histórico próximo, que se pode considerar o principal motivo da redação desse discurso em favor da paz, deve-se destacar que estavam em curso as guerras da Liga de Cambrai (1508-1510), da Liga Santa (1511-1513) e, por fim, da aliança franco-veneziana (1513-1516). Como alguns desses países ou seus soberanos são explicitamente mencionados na Queixa $d a P a z,{ }^{13}$ uma tabela pode esclarecer o intrincado jogo político de interesses de nações que essas ligas envolviam:

\footnotetext{
13 Erasmo menciona os reis de modo respeitoso de modo a não contrariá-los. Sua menção, porém, para os conhecedores dos fatos, poderiam soar como ironia: "Príncipe Carlos, adolescente de índole incorrupta. E não descuida de mim o Imperador Maximiliano. Nem a isso se recusa Henrique, o ínclito rei da Inglaterra" (Erasmo de Rotterdam. Queixa da Paz). Carlos V (1500-1558), herdeiro do Imperador do Sacro Império Romano Alemão, com apenas 17 anos de idade por ocasião da publicação do Querela. Carlos só assumiria o Império Habsburgo em 1519. Maximiliano I (1459-1519) contava apenas 18 anos na época da publicação do Querela, morreria dois anos depois. Henrique VIII (1491-1547), Rei da Inglaterra de 1509 até a sua morte. Erasmo elogia a catolicidade do rei inglês porque este seria excomungado somente em 1533 e romperia com Roma em 1536.
} 
Alianças durante as guerras posteriores à Liga de Cambrai

Liga de Cambrai (1508-10)

\begin{tabular}{c|c}
\hline $\begin{array}{l}\text { Estados Pontifícios } \\
\text { França }\end{array}$ & República de Veneza \\
Sacro Império Romano Germânico \\
Coroa de Aragão \\
Ducado de Ferrara
\end{tabular}

Aliança franco-veneziana (1513-16)

\section{Estados Pontifícios}

Espanha

Sacro Império Romano Germânico

Inglaterra

Ducado de Milão

Mercenários Suíços
República de Veneza

França

Escócia

Ducado de Ferrara 
Erasmo, em sua Querela, critica nominalmente o já falecido Papa Júlio II, que, no governo dos Estados Pontifícios, e por causa de suas alianças militares, passou para a História como o "Papa Guerreiro", e que ele havia chamado de Julius Exclusus (1968, p. 27), expulsando-o do paraíso por intermédio de um Pedro que via no papa acompanhado de soldados "um espetáculo nunca visto antes, para não dizer um monstro". Que este tenha sido de fato o motivo decisivo para que o autor humanista escrevesse essa "Queixa da Paz", provao não somente a alusão aos países ao final deste escrito, mas o próprio autor informou acerca das circunstâncias da redação desse texto em uma carta endereçada a João Botzheim:

Escrevi a Queixa da paz há cerca de sete anos, quando fui convidado pela primeira vez para a corte do príncipe. Faziam-se então grandes preparativos em Cambrai para uma conferência que reuniria os maiores príncipes do mundo - o imperador, o rei da França, o rei de Inglaterra, o nosso Carlos -, a fim de selarem entre si a paz com laços de aço, como é costume dizer-se. À frente desta ação diplomática achavam-se o ilustre Guilherme de Chièvres e João Sauvage, grande chanceler, vocacionado para o serviço do Estado. Opunhamse a este projeto aqueles que não viam nenhuma vantagem em que reinasse a tranquilidade, aqueles que, segundo a expressão de Filóxeno, (...) preferem de longe uma paz que não seja uma paz, uma guerra que não seja uma guerra. Foi assim que, a pedido de João Sauvage, escrevi a Queixa da Paz. As coisas de fato encaminharam-se de tal sorte que teria sido mais acertado escrever Epitáfio da paz, pois não restam quaisquer esperanças de que ela possa escapar com vida (Erasmo de Rotterdam. Epistola a João Botzheim. 1523. Correspondence of Eramus. Toronto: University Toronto Press, 1989, p. 319).

Nesta carta, Erasmo poderia estar se referindo aos diversos conflitos ocorridos entre 1517 e 1523, como a Sexta Guerra da Itália (1521-1526), também conhecida pela disputa entre Valois e Habsburgos, as duas mais importantes dinastias da Europa.

$\mathrm{Na}$ epístola introdutória publicada juntamente com a "Queixa da Paz", Erasmo concebe o escrito como em defesa da França (Carta ao Bispo Felipe de Utrecht, 1917, 11. 2335). Contudo, para Rodrigues, Erasmo visava diretamente os interesses holandeses:

a Queixa da Paz, escrita já tendo em vista Carlos de Gent como soberano dos reinos espanhóis, enfatizava a necessidade de não insistir na política antifrancesa da qual os Países Baixos eram vítimas tradicionais. Assim, a política erasmiana assumia, de acordo com Mesnarde, os anseios dos corpos sociais neerlandeses (Rodrigues, 2012, p. 154-155).

De fato, alguns dos argumentos contidos no texto em estudo abordam as dificuldades impostas à circulação de mercadorias que era o motor econômico dos países baixos e da região renana. Entretanto, pode-se dizer que não seria correto afirmar Erasmo como defensor dos interesses particulares da França, dos Países Baixos ou de qualquer dos contendores das 
Guerras da Liga de Cambrai, uma vez que seus argumentos a favor da paz são aplicáveis a qualquer nação, visam o bem da humanidade, como é próprio do irenismo defendido por ele.

\subsection{Reações à declamação da paz}

Erasmo será o autor cujas obras foram mais difundidas, comentadas e, a partir de certo momento, também contestadas, como se pode averiguar pelas diversas reedições, traduções e referências a estas em outros autores do período. Por ocasião da publicação da "Queixa da Paz”, o roterdamês recebeu algumas cartas de elogio, conforme se denota do seu epistolário (Allen, Ep. 95, n. 1. II), até o final da segunda década de 1500, nessa fase anterior à Reforma, em que o prestígio de Erasmo, o então "preceptor da Europa", era intocável. Impressionam, ademais, as inúmeras edições em latim e as diversas traduções para os vernáculos. Margolin (1992, p. 911) informa a existência de pelo menos vinte seis edições nos dozes anos subsequentes à primeira edição, perfazendo a soma de mais de trinta edições, tendo como recorte o século XVI (Rummel, 1990, p. 288). Contam-se ademais diversas traduções para as principais línguas europeias ocidentais, por exemplo, duas traduções para o alemão em 1521, uma para o francês e para outros vernáculos incluindo o holandês, cuja primeira aparição se deu em 1567 (Augustijn, 1995, p. 73). Radice (1968, p. 290) observa que, embora Erasmo já houvesse falado contra a guerra em obras como "Panegírico" (1504) e nos "Adágios" (1515), deve-se considerar a Queixa da Paz "como o mais citado e celebrado apelo pela paz universal". Não é de se admirar que seus principais trabalhos até então publicados, especialmente sua tradução do "Novo Testamento" e suas declamações "Elogio da Loucura" e "Queixa da Paz", tenham-no tornado um pensador do norte prestigiado em toda a Europa, cujo centro cultural era a Itália, a ponto de em 1522, Vives afirmar: "é de pasmar a admiração inspirada por Erasmo a todos os espanhóis, sábios, ignorantes, homens de igreja e seculares" (Epístola de 6 de setembro de 1522, apud Bataillon, 2007, p. 156). Este testemunho pode ser entendido como benévolo e parcial uma vez que desconsidera os inúmeros ataques sofridos por Erasmo na península ibérica, sobretudo após as traduções bíblicas e os acontecimentos da Reforma. Na verdade, o próprio ataque direto e polêmico efetuado contra as traduções só atesta o alcance de sua influência. 


\subsection{A disposição retórica}

Chomarat (1981, p. 931), ao longo do capítulo III de seu Grammaire et Rhétorique chez Érasme, denominado La Declamation, fornece uma lista de declamações e analisa esse gênero tal como exercido pelo humanista holandês, especialmente no "Elogio da Loucura". No entanto, o pesquisador dedicou apenas alguns parágrafos à "Queixa da Paz" sem se estender na explicação de sua forma, da sua disposição segundo os ditames da retórica e da natureza dos seus argumentos, limitando-se a estruturá-la em três partes principais:

A argumentação desenvolve três ideias sucessivas: a natureza constituiu o homem para a benevolência e para a concórdia; a doutrina de Cristo consiste na paz, concorda com o amor mútuo, a guerra é uma fonte de calamidades; na segunda parte, bem mais longa, após ter demonstrado a discórdia que reina em toda parte até mesmo entre os monges e entre os esposos, apesar do ensinamento de Cristo, a Paz descreve a presença da guerra, sobretudo nos últimos dez anos, com o aumento das agruras e do escândalo: guerra entre os cristãos, guerra das quais participam os padres e mesmo os papas, enfim, ó dor! guerras travadas em nome de Cristo; a religião da paz foi pervertida ao serviço da guerra: nos dois campos se recita o Pater Noster; esta progressão é seguida de uma confutatio do argumento, invocado por certos cristãos, segundo o qual os beligenrates obedecem a uma certa necessidade, coagidos à guerra, apesar da sua própria vontade. Esta confutatio analisa as fontes reais da guerra (as paixões), e afirma que a condição primeira da paz é a vontade da paz entre certos príncipes, mas também no clero e no povo. Na terceira parte, salienta, entre as consequências dos conflitos armados, não somente as ruínas e a miséria dos povos, mas as lições de infração às leis, o vício e a impiedade que dá à guerra "a desonra do nome cristão" [...]. A indignação, a dor, a piedade inspiram Erasmo a belas passagens; os conselhos práticos, o apelo à regularização dos conflitos através de negociações, a insistência sobre a responsabilidade destes diretores de opinião que são os pregadores, e os conjuramentos aos príncipes cristãos que fazem perceber que esta declamação não seria somente um exercício; somente o artifício da prosopopeia mantém ainda a Querela Pacis ao gênero que ilustraram obras precedentes [as demais declamações] (Chomarat, 1981, p. 999-1000).

No "Sobre a abundância", de 1512, Erasmo havia afirmado que "na ordem ou disposição é sumamente necessário o método", ou seja, a lógica e a clareza da argumentação devem evitar uma sensação de perturbação ou confusão (De Copia. Liber II, p. 280, 11. 95-99). Deve-se distinguir nisso que o roterdamês também chama de ordo ou constructio, a sequência das palavras dentro de uma frase (De Copia. Liber I, p. 75, 11. 47-49). Para ele, é necessário selecionar as proposições de modo adequado justamente pelo critério do que se acha conveniente ou agradável. Deve-se, pois, hierarquizá-las e transitar entre elas tomando por regra aquelas que são mais próximas umas das outras, de modo que se evitem saltos temáticos não adequados (De Copia. Liber II, p. 228, 11. 781-787). Erasmo preceituava no "Sobre 
abundância", assim como no subtítulo "Sobre a ordem" do seu "Sobre a redação de epístolas" (De conscribendi epistolis, p. 301, 11. 2-15), que a ordem ou disposição devem partir do critério do que é "natural" e do que é "artístico", aconselhando que deve ser menos frequente o caráter artístico, uma vez que os leitores não são do vulgo, mas eruditos, e que tais epístolas não são ouvidas, mas lidas. Ademais, embora a disposição seja necessária para a clareza, em alguns gêneros, como é o caso do epistolar, essa disposição deve ser dissimulada e não ostensiva. Contudo, o que Erasmo mais recomenda evitar é um texto confuso, por falta de disposição adequada. Ainda nesse escrito, encontram-se no subtítulo "Sobre o gênero dissuasório" algumas afirmações pertinentes a respeito da suasória, como é o caso da "Queixa da Paz", no sentido de que recomenda a paz e desaconselha a guerra. Para ele, o ato de desaconselhar algo a alguém implica na seleção de argumentos que são desagradáveis para aquele que pretendemos dissuadir. As proposições devem ser dispostas de modo que sua compreensão seja simplificada através de exemplos e comparações, sem deixar evidente a disposição (De conscribendi epistolis, p. 429, 11. 5-20).

Do ponto de vista da disposição, a "Queixa da Paz" parece seguir uma subdivisão concorde com a tradição retórica (Silva, 2015, p. 60), que o próprio Erasmo propunha que fosse ensinada aos alunos, em seu "Plano de estudos" (p. 134, 1. 10-135, 11. 1-5). Basicamente, ela se subdivide em:

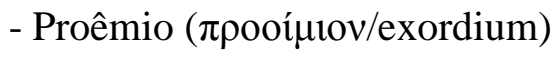

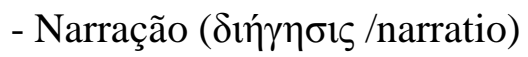

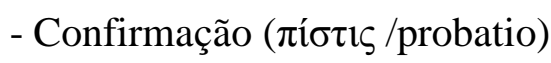

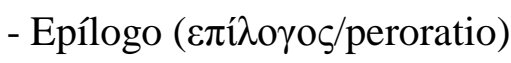

No caso específico da declamação irênica, as edições, inclusive aquelas revisadas por Erasmo, apresentam uma epístola a Felipe, Bispo de Utrecht (Carta ao Bispo Felipe de Utrecht, 1917, 11. 23-35), que se assemelha àquilo a que hoje correntemente se intitula como dedicatória, na qual o autor saúda o bispo pelo novo cargo, desejando-lhe o mesmo sucesso de seus antepassados. Em certo trecho desta epístola, menciona ainda a situação de seu tempo como motivação para a redação da "Queixa da Paz". 
Já no título da declamação, Erasmo explicita o tema: “Queixa da Paz, perseguida e rejeitada em toda parte pelas nações" (Querela Pacis undique gentium eiectae profligataeque), assim como ocorria nas controvérsias senequianas, que apresentavam a temática de forma clara logo na primeira frase ou em um breve texto que introduzia a causa em discussão (Schwartz, 2004, p. 71). O título apresenta o tema principal do discurso (a Paz), cuja causa é típica do gênero deliberativo e das antigas suasoriae; a Paz é tratada também como uma personificação ofendida, a personagem principal e remetente do discurso, tal como ocorre na sexta suasória de Sêneca, na qual Cícero é o interlocutor fictício (Schwartz, 2004, p. 110). Esta apresenta sua queixa. Trata-se do lamento da injúria e da tentativa de destruição contra a Paz. As declamações costumavam antepor suas personagens geralmente fictícias em uma disputa. No caso da Querela, já no título da obra há personagens explícitas (a Paz, como protagonista, com voz ativa, e as nações, sem voz ativa), e uma indicação genérica de lugar (em toda parte). Todo o universo, em todo lugar, conspira contra a paz, e esta apresenta sua queixa com argumentos já explorados pelo roterdamês no "A guerra é doce para os inexperientes" (1515) e na "Instituição do príncipe cristão" (1516). Contudo, não são os argumentos que diferenciam esta declamação dos demais escritos em favor da paz ou contrários à guerra, mas sim sua forma, ou seja, seu gênero, assim como os recursos retóricos presentes no texto.

Aplicando a tradição de disposição retórica às declamações, podemos dividi-la nas seguintes partes:

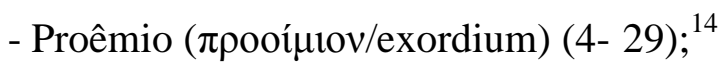

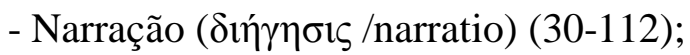

- a primeira parte trata da paz entre os animais (30-112);

- a segunda parte trata da destruição da paz entre os homens (113-202);

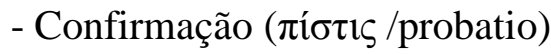

- a primeira parte trata de Cristo pacífico, exemplo a ser seguido pelos que se dizem cristãos (203-401);

\footnotetext{
${ }^{14}$ Os números arábicos se referem às linhas da edição crítica da obra de Erasmo (Desiderii Erasmi Roterodami Opera Omnia. Amsterdam, 1978).
} 
- a segunda parte trata do exemplo dos pagãos (402-435);

- a terceira parte trata de como o Estado, as leis, o comércio e o povo são prejudicados pela guerra (436-594);

- a quarta parte trata de sugestões para o príncipe evitar a guerra (595-871);

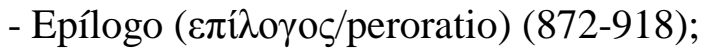

Em algumas edições, a indicação pax loquitur, excluída da edição crítica, dá início ao proêmio ( $\pi \rho \circ o$ íntov/exordium), este localizado logo após a epístola ao bispo Felipe e ao título (1-3). Vem a seguir uma espécie de auto-apresentação da Paz (4-29), a qual fala na primeira pessoa do singular, descreve a si mesma e aos males que os homens injustamente cometem, contra ela e contra si mesmos.

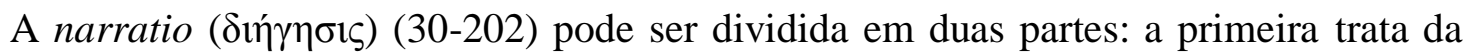
paz entre os animais (30-112), cujo objetivo talvez seja mostrar que esta é conforme a natureza, ao passo que a guerra, contrária. Esta é péssima justamente porque se opõe à natureza das coisas (rerum natura), e, nisso, os próprios animais, apesar de seres irracionais e não dotados da palavra, serviriam de exemplo a ser seguido pelo homem. Quando este se faz guerreiro torna-se abjeto, pois contraria sua natureza racional. Já a segunda parte trata da destruição da paz entre os homens (113-202): entre as linhas 113-130, Erasmo indica os cristãos e a cidade como adversários dela, que não pode obter uma "morada" entre eles. Em seguida, volta-se contra os príncipes (131-142), os eruditos (143-157) e os religiosos (158189). Inclusive se refere à família como lugar no qual ela é maltratada (190-194). O próprio homem é um ser dividido, pois a razão luta contra as paixões e estas entre si (195-200).

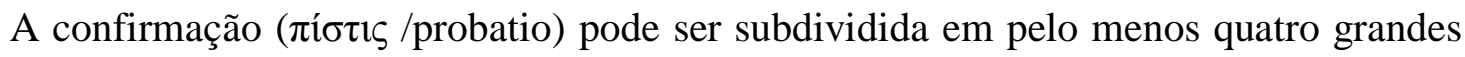
blocos: a primeira parte trata do Cristo pacífico, exemplo a ser seguido por todos aqueles que se dizem cristãos (203-401). Erasmo recusa aqui que o epíteto "Deus dos exércitos", presente em trechos do Antigo Testamento, possa servir de argumento a favor da guerra (223-230). Verifica-se que a fala dirigida ao príncipe cristão (249) se assemelha em certas partes do discurso ao gênero speculum principum, ${ }^{15}$ tão em voga no Renascimento, a ponto de Erasmo ter dedicado vários de seus escritos a esse objeto, nos quais, inclusive, incorrem argumentos 
irênicos comuns à "Queixa da Paz" e que serão considerados em pormenor abaixo. O gênero "Espelho dos príncipes" é uma espécie de manual ético e político em que se detalham as virtudes e os deveres de um príncipe ideal. Tratava-se de uma tentativa de promover um príncipe justo e um governo análogo. Acreditava-se, desde a antiguidade até no período medieval, que a formação moral do governante determinaria a felicidade dos súditos. Se Cristo é o príncipe da Paz, não cabe aos príncipes que se dizem cristãos promover a guerra. Homens reais são, então, retratados como mais cruéis que personagens da história ou da antiga mitologia, como Dionísio e Mezêncio (428-429). Uma terceira parte aborda como o Estado, as leis, o comércio e o povo são prejudicados pela guerra (436-594). Note-se o trecho elogioso à França (436-450), que justifica o tom francófilo do discurso, cofnroem o pedido do chanceler João Sauvage que teria encomendado a redação desta declamação. Entre 451e 473, Erasmo retorna ao argumento de que os homens são mais cruéis que as feras. O bloco mais extenso do discurso, a quarta parte da confirmação, dirige-se diretamente ao príncipe, apresentando sugestões para que este evite a guerra (595-871). O epílogo ( $\varepsilon \pi i ́ \lambda o \gamma o \zeta /$ peroratio) (872-918) apresenta-se sob uma forma de apelo a todas as pessoas, a começar pelos poderosos, para que promovam a paz. Segue-se o princípio da rememoratio, sugerido pelas tradições dos manuais de retórica, com a finalidade de retomar rapidamente os argumentos desenvolvidos anteriormente. Finalmente, o próprio autor resume o conteúdo da argumentação desenvolvida por todo o texto:

Tudo nos convida a isso. Em primeiro lugar, o próprio instinto da natureza, e, se assim posso dizer, a própria humanidade. Em segundo lugar, o próprio Cristo, Príncipe e Autor de toda felicidade humana. Depois, as incontáveis vantagens da paz, contrastadas com o número imenso das calamidades da guerra. Convidam à paz até mesmo as inclinações dos príncipes que, como que inspirados por Deus, já estão propensos à concórdia (Queixa da Paz, 889892).

\subsection{As sentenças e os adágios}

Sentenças e adágios são recursos recorrentes nas declamações erasmianas, assim como o foram na obra senequiana, segundo as tradições retóricas antigas transmitidas por Quintiliano (Instituição Oratória, XII, 10, 48). Em epístola a Willian Blount, embora não se refira expressamente ao uso delas no gênero que estudamos, afirma Erasmo sobre o uso de sentenças em geral: 
O provérbio melhora com a idade exatamente como os vinhos. Eles não se limitam a ornamentar o seu estilo. Eles são igualmente úteis para também lhe dar força. Por esta razão, Quintiliano não só os incluiu entre os meios de aliviar o tédio judicial, entre as figuras de oratória, mas considera que o exemplo proverbial é um dos métodos mais eficazes de prova, se o seu propósito é convencer, ou para refutar o seu adversário por meio de um ditado espirituoso, ou para defender a sua própria posição (Epístola 125, 11. 56-65. Steyn, junho de 1500, I. The Correspondence of Erasmus. I. 1974, p. 255, tradução do inglês para o português).

Logo no início do "Sobre a abundância", Erasmo pontua como as sententiae são recursos basilares da sua retórica, que têm o poder de conferir qualidade e elegância ao discurso, ainda que também tragam em si "o perigo não reduzido de deixá-lo afetado" (De Copia, I, 9, p. 26). Um dos erros apontados pelo holandês é a inadequação com o tema ou com o argumento proposto, ou seja, um adágio que contrariasse o que a antiga tradição retórica nomeava como decoro, ou então o uso exagerado, qualificado como "sententiarum turba", que não é capaz de reduzir a pobreza inerente ao discurso (Ibid.).

Deve-se salientar a diferença entre sententia, no sentido de provérbio, e a sentença no sentido frase ou oração, que também foi objeto de consideração do roterdamês. Relembrando a célebre disputa entre Cícero e Róscio, sobre qual dos dois seria capaz de repetir uma mesma ideia com o maior número de formas sinonímicas, concebe a proposição fundamental segundo a qual a variação das sentenças enriquece o discurso (De Copia, I, 40-45, p. 28). Erasmo ousa ainda afirmar que não é somente a variação copiosa das sentenças que é capaz de tornar um discurso eloquente, mas também a concisão, de modo que a parcimônia é um fator relevante para um discurso retoricamente constituído:

Não raro temos de dizer a mesma coisa várias vezes, mas nesse caso, se faltar variação, ou perderemos, ou faremos como o cuco, de modo que repitamos as mesmas palavras repetidas vezes, sendo incapaz de dar diferente forma ou color para a sentença, de maneira que nossa falta de eloquência parecerá ridícula a nós mesmos e esgotará totalmente o nosso público de miserável cansaço (De Copia, I, 130-134, p. 32).

Nota-se o uso da expressão color com um sentido semelhante àquele utilizado por Sêneca, o Velho, em suas declamações, as quais haviam sido editadas por Erasmo um ano antes da publicação da Querela e que, segundo Knott (1988, p. 12), tiveram influência direta sobre a declamação e a coleção de adágios erasmiana. Embora não trate exatamente da sentença senequiana enquanto provérbio, ao longo do capítulo XVII do De copia, Erasmo aborda um tema que possui certa analogia com o critério para a seleção das sentenças. Ao 
discorrer sobre a importância da metáfora ou das similitudines como recurso retórico capaz de conferir ao discurso ornamento, gravidade, sublimidade e humor (De Copia, I, 801-803, p. 64), apresenta a coleção de adágios (De conscribendis epistolis, p. 240, 11. 15-16) que enriquecem o texto, mas que devem ser selecionados com critério: "a metáfora não ser dura, ou baixa, ou mais exagerada do que é adequado, ou dessemelhante, ou demasiado frequente, especialmente a que é da mesma espécie" (De Copia, I, 817-818, p. 64). Ao que parece, Erasmo se refere ao uso moderado, não repetitivo no tocante à forma e ao conteúdo da sentença.

O próprio roterdamês colecionou centenas de adágios na edição expandida publicada em 1508 e que são utilizados (De Copia, I, 812-814, p. 64), segundo Knott (1988, p. 12), não somente como meras traduções para o latim, quando advindos do grego, ou meras citações literais, quando originários do latim, mas em alguns casos são parafraseadas, ou, ao menos, demonstram certa semelhança, justamente para dar variedade e elegância às diversas sentenças, muito embora a maioria delas seja apenas recolhida dos escritos antigos com a finalidade de ornamentar o discurso, como é o caso da "Queixa da Paz". Erasmo não se abstém do uso de adágios com finalidade retórica. Nesse particular, podemos constatar que tais adágios possuem três fontes específicas e em muitos casos grafadas na edição crítica da Queixa da Paz e que, de certo modo, coincidem com a lista supracitada de Knott (1988, p. 12), ao serem classificadas em quatro fontes: as antigas, as bíblicas, as patrísticas e os próprios adágios de Erasmo.

Algumas destas referências se configuram apenas como citações diretas ou indiretas dos autores. Algumas podem ser explícitas, como é o caso de Platão (linhas 9 da epístolaprefácio e (551), enquanto outras são alusões, como Lívio $(1-3)^{16}$, de Homero $\left(75^{17}\right)$, de Ovídio $\left(162^{18}\right)$, de Sílio Itálico $\left(210^{19}\right)$, de Cícero $\left(218^{20}\right.$ e $\left.758^{21}\right)$, de Virgílio $\left(467^{22}\right.$ e $\left.670^{23}\right)$ e

\footnotetext{
16 "undique se suosque profligante fortuna" (Livio. 33,19).

17 “Circes pharmacis” (Homero. Odisseia, X, 235ss).

18 "vestes candidae meo colore" (Ovidio. Arte Amatória, 3, 502).

19 “pax optima rerum” (Silio. Púnicas. XI, 592ss).

20 "a viro laudato" (Cícero. Disputas Tusculanas, IV, 31, 67).

21 "silent leges inter arma" (Cicero. Mil. 4, 10).

22 “ignobile vulgus" (Virgílio. Aeneida, I, 149).

23 "quae máxima turba est” (Virgílio. Aeneida, VI, 611).
} 
de Plauto $\left(764^{24}\right)$. Há citações de adágios recolhidos e selecionados por Erasmo em sua própria coletânea (linhas $18^{25}, 22^{26}, 62^{27}, 77^{28}, 91^{29}, 155^{30}, 505^{31}, 553-556^{32}, 803-804^{33}, 866^{34}$ e $\left.906^{35}\right)$. Alguns são inspirados em fontes antigas, como o de Plínio $\left(57^{36}\right)$, de Horácio $\left(152^{37}\right)$ ou de Aristóteles $(391)^{38}$. Erasmo de modo algum aconselha a seleção de sentenças de um único autor, mas a imitação e a coleção destas retiradas das mais variadas fontes, inclusive as de origem ou inspiração bíblica e patrística, chegando inclusive a ridicularizar no "Diálogo Ciceroniano" (p. 617, 11. 9-12), mais especificamente no diálogo entre as personagens Nosópono e Buléforo, os autores que se aferravam unicamente à coleção das sentenças e adágios oriundos ou inspirados na obra atribuída a Cícero. Erasmo é eclético no elenco das fontes, mas foi constantemente acusado de falta de cuidado no uso das sentenças.

Conforme lê-se no "Plano de estudos", o estímulo aos estudantes de retórica para o cultivo da coleção e o conhecimento de adágios e sentenças dos antigos é imprescindível para o enriquecimento do discurso em conformidade com a tradição retórica antiga, pois são fontes da invenção, da abundância e da variação das sentenças (De ratione studii, p. 149, 11. 18-27). Por fim, Erasmo chega a afirmar explicitamente no "Sobre a redação de epístolas" a necessária imitação das sentenças colecionadas entre os autores, citando inclusive, as declamações de Luciano a Aulo Gélio (De conscribendis epistolis, p. 532, 11. 8-12).

24 “parietum perfossor" (Plauto. Pseud. 9, 8, 6).

25 "Pax omnium bonarum rerum et parens est et nutrix" (Erasmo. Adagia, 3001).

26 “igens malorum pelagus" (Erasmo. Adagia, 3001).

27 "Furemque fur cognoscit" (Erasmo. Adagia, 1263)

28 "uni lachrymas clementiar et misericordiae symbolum" (Erasmo. Adagia, 3001).

29 "solum hominem nundum produxit" (Erasmo. Adagia, 3001).

30 "dentata charta" (Erasmo. Adagia, 87).

31 “e suggesto sacro" (Erasmo. Adagia, 3001).

32 “"'Ethnicorum leges... parricídio” (Erasmo. Adagia, 3918).

33 “ad Cares vilíssimos” (Erasmo. Adagia, 514).

34 “Acta est fabula" (Erasmo. Adagia, 239).

35 "Bellum e bello seritur" (Erasmo. Adagia, 3001).

36 "Leonum feritas inter se non dimicat, serpentium morsus non petit serpentes, ne maris quidem beluae ac pisces nisi in diversar genera sacuiunt" (Plinio. História, VII, 5).

37 “de lana caprina” (Erasmo. Adag. 253; Horácio. Espístulas. I, 18,15).

38 "Conciliant homines mala" ou "mala conciliant et malos" (Erasmo. Adagia, 1071) 


\subsection{Declamação e espelho dos príncipes}

Se a declamação, desde o início, possuiu uma relação estreita com outros gêneros como a oração (oratio) e o diálogo (sermocinatio), identificamos outro correlato: o espelho dos príncipes. Ora, não somente o tema aproxima a "Queixa da Paz" da "Instituição do príncipe cristão", mas também, sobretudo, em algumas de suas partes que aconselham o suserano. Herding (1974, p. 6) aponta que ainda o "Panegírico a Felipe" e a "Insituição do priníncipe cristão" se caracterizam como obras erasmianas pertencentes a esse gênero literário. Por outro lado, os argumentos utilizados na "Queixa da Paz", ao parecer de Herding (1974, p. 9), configuram a própria "Instituição do príncipe cristão" como um tratado de índole irênica. O autor (1975, p. 98) também observou que Plutarco, cuja obra moral tinha sido editada e publicada por Erasmo em 1514, pode ter influenciado o roterdamês na redação de seus escritos suasórios e pedagógicos dirigidos especificamente aos príncipes. O próprio Erasmo, já na carta a Felipe, aquela que introduz a "Queixa da Paz", dirige-se a membros da nobreza, e em epístola a João Botzheim, datada do ano de 1523, afirma sua declamação como um escrito cujos destinatários são justamente membros governantes. Herding (1974, p. 100) levanta a hipótese de que, tal como esta, também seu mais célebre espelho do príncipe tenha sido encomendada pelo chanceler João Sauvage. Esse escrito, então, seria de suasório e pedagógico no sentido de sugerir atitudes moralizadoras das relações entre os príncipes e os seus congêneres, entre estes e o povo.

Em todo o texto da "Queixa da Paz" há cinquenta e seis repetições da palavra "príncipe", muitas vezes em uma função apelativa através do uso do vocativo. Para Erasmo, o gênero speculum segue um modelo: Cristo, que é o "Príncipe da paz" (Queixa da Paz, 205214). Erasmo trata do regente bom (614 e 770) ou pio (770) e se propõe aconselhá-los a deliberar em favor da Paz, em nome de princípios éticos, tal como é típico das suasórias (Queixa da Paz, 205-214). Até mesmo na peroração, a Paz novamente volta-se a eles (Queixa da Paz, 872-876). As dezenas de refências ao governante e a semelhança de alguns trechos com o gênero espelho de príncipes não desautorizam a classificar a "Queixa da Paz" como declamação, pois o tema sobre a paz, típico do gênero deliberativo e o objetivo de aconselhar, próprio das suasórias, são elementos correntes nas antigas declamações.

Por fim, deve-se considerar que Gaeta (1969) notou semelhanças evidentes entre o diálogo filosófico presente no exórdio do "Sobre a Clemência" do Jovem Sêneca, com o da 
“Queixa da Paz”. Notei que grande semelhança da Queixa da Paz com o exórdio de Sêneca (Sobre a clemência, 1-4). Aquele foi um escrito filosófico-moral destinado ao jovem imperador Nero, de modo a contribuir com a formação deste (Manjarrés, 2001, p. 85) e que, de modo fictício, simula discursos diretos de Nero (ver I.2), ao passo que na declamação em estudo, a locução direta é proferida pela própria Paz. Sêneca, o Jovem, inicia sua argumentação apresentando o próprio Nero como fonte dos dons, virtudes e bens e o contrasta com a humanidade "briguenta, intriguenta e apaixonada", capaz de causar "a ruína para si mesma". Sêneca instrui o imperador a se auto-apresentar como aquele que cumpre o ofício de Deus sobre a terra, como o árbitro da vida e da morte. Cabe ao governante decidir as posses do homem, pois a fortuna de cada um provém da sua boca. Ele deve decidir sobre qual inimigo deve ser tratado com rigor ou clemência, pois cidades e civilizações florescem pelas suas palavras. Mas Nero prefere promover a paz, para benefício dos povos que lhe são submetidos. Já consideramos e ainda aprofundaremos como a paz se apresenta de modo análogo e com argumentos semelhantes. Em ambos os discursos, elaborados em primeira pessoa, usam-se as imagens da prosperidade para a paz e da destruição para a guerra; em ambos, embora a paz seja apresentada como agradável aos céus, ou seja, aos deuses, e aos homens, esta não é aceita e perde seu lugar para a guerra.

\subsection{Traços de suasória e de elogio}

Ao estudar a "Queixa da Paz" sob a perspectiva dos três gêneros, notamos novamente a ocorrência especial de traços destes gêneros: o deliberativo ou suasório e o demonstrativo ou epidítico. O primeiro ocorre, sobretudo, nos trechos em que a Paz se configura como benévola conselheira (Queixa da Paz, 595-597). A Paz volta-se ao suserano a fim de aconselhá-lo, referindo-se na forma da terceira pessoa do singular:

A um coração régio cabe ignorar os afetos privados e estimar todas as coisas segundo o bem-estar público. Por isso, que o príncipe evite viagens a terras longínquas, ou antes, que nunca cruze os limites territoriais do seu reino (Queixa da Paz, 646-647).

A Paz também utiliza a segunda pessoa do singular, ao dirigir-se diretamente ao cristão a fim de defender sua causa, tal como se verificou em já citada parte da peroração (Queixa da Paz, 872-876). Entretanto, esta não se dirige como conselheira apenas do poder laico, mas tenta persuadir o próprio Sumo Pontífice: 
Suma é a autoridade do Pontífice Romano. Entretanto, no momento em que os povos e os príncipes se enfrentam em guerras perversas - e isto por longos anos - onde está a autoridade dos pontífices junto às nações? Onde está o seu poder, próximo ao de Cristo? Era nesse ponto e então que a autoridade papal certamente deveria ser exercida, a não ser que os papas também compartilhem as mesmas ambições (Queixa da Paz, 583-586).

Os conselhos deliberativos assumem a construção do futuro, mas também o subjuntivo, como, por exemplo, nesse trecho no qual a Paz sugere regras com finalidade pacífica no tocante ao direito de sucessão de territórios:

Assim, cada qual se esforçará segundo suas possibilidades para governar sua região da melhor forma possível. Pois, quando estiver totalmente concentrado no cuidado de um só reino, fará o máximo para deixá-lo aos seus filhos, enriquecido por melhorias. E, desta forma, como é evidente, tudo florescerá. Que sejam aliados não apenas por vínculos matrimoniais ou alianças contratuais, mas sim unidos por amizade sincera e pura e, acima de tudo, por um idêntico e comum amor por todo o gênero humano. Que a sucessão do rei seja atribuída quer àquele que for o mais próximo por consanguinidade, quer àquele que, pelos votos do povo, for considerado o mais capaz. Quanto aos demais, que lhes baste estar entre o número dos nobres mais honrados (Queixa da Paz, 639-645).

Ao comentar o "Elogio ao matrimônio" (1518), publicado um ano após a publicação da "Queixa da Paz" (1517), Leushuis (2004, p. 1287) estabelece uma definição que parece adequada à declamação que estudamos:

Primeiramente publicada em março de 1518 sob o título de Declamatio in genere suasorio de laude matrimonii, o texto combina elementos da declamação (declamatio) e do elogio (laus). Ao considerar a natureza geral da declamação, pode-se dizer que o objetivo deste texto é discutir os argumentos a favor e contra (in utramque partem) a tese (thesis) em um modo suasório (genus suasorium). Na linha da tradição clássica ciceroniana, na qual o gênero era usado para discutir uma questão abstrata ou filosófica [...], as declamações do início do século XVI expressam o valor dos julgamentos dos seus autores sobre problemas morais ou éticos por meio da retórica do louvor ou do vitupério (laus e vituperatio) (Leushuis, 2004, p. 1287).

Além disso, Querela pode ser traduzido por queixa, lamento ou queixume, mas também possui um sentido muito próximo a vitupério ou reclamação, pois quem se queixa vitupera, reclama ou lamenta algo. ${ }^{39}$ Verificou-se alguns trechos da declamação que apresentam traços do gênero epidítico, como quando Erasmo empresta a voz para a Paz fazer sua própria exaltação na primeira pessoa do singular (Queixa da Paz, 18-21). Em outra parte, a Paz exalta-se a si mesma com o uso da terceira pessoa do singular: "Com tão grande número

\footnotetext{
${ }^{39}$ Cf. Gaffiot, F. Latin Dictionnaire Latin-Français. Paris: Hachette, 2000. Voz Querela.
} 
de argumentos a natureza nos ensinou a paz e a concórdia; a ela nos convida com tão grande número de seduções; para ela nos arrasta e compele com tantos laços e razões!" (Queixa da $\mathrm{Paz}, 103-104)$. Erasmo também utiliza o arquétipo de Cristo como argumento para exaltá-la (Queixa da Paz, 203-222).

Em vários trechos, a Paz se auto-elogia por meio de uma comparação com Cristo, a fim de exaltar seu próprio êthos e de associar-se a sua autoridade, assim como àquela de Davi e Salomão, monarcas bíblicos que favoreceram Israel com a prosperidade gerada pela paz. Erasmo estabelece um contraste típico do gênero epidítico, que são as vituperações à causa contrária sucessivas aos elogios à causa que se está defendendo (Queixa da Paz, 237-248).

Em outro excerto, o paralelismo entre vituperação e elogio é alternado. Começa-se pela censura e passa-se ao encômio e vice-versa:

Que os mortais desculpem com sua fraqueza o que quiserem, mas se, de fato, não amassem a guerra, não lutariam de tal modo entre si com batalhas contínuas. Olhai para o Cristo já adulto! Que outra coisa ensinou, que outra coisa expressou, senão a paz? Além disso, ele saúda os seus discípulos com o cumprimento da paz: "a paz esteja convosco", e lhes prescreveu essa forma de saudação como a única digna dos cristãos. Os Apóstolos não se esqueceram desses preceitos, e recomendavam a paz em suas cartas, e desejavam paz àqueles a que amavam de forma especial. Escolhe coisa importante, quem faz votos pela saúde, mas está desejando o sumo da felicidade. Ele, que a tinha recomentado durante toda a sua vida, nunca deixou de a recomendar. Vede com quão grande solicitude a recomenda quando estava prestes a morrer: "Amai-vos uns aos outros, como eu vos tenho amado". E novamente: "eu vos deixo a paz, eu vos dou a minha paz" (Queixa da Paz, 259-268).

A "Queixa da Paz" também pode ser vista como pertencente à espécie do epidítico chamada lamentação. Tal fenômeno corre logo no exordium (Queixa da Paz, 4-17). Destacam-se no trecho supracitado alguns verbos que denotam a lamentação: deplorare e deflendi sunt, assim como a expressão: mea iniuria. Esse formato de lamento ocorre em vários trechos esparsos pela obra, como o início do primeiro argumento, no qual Erasmo defende que a guerra contraria a natureza humana (Queixa da Paz, 30-31). Em um longo período, a personificação da Paz lamenta ou vitupera o fato de ter sido destruída pelos homens, inclusive pelos cristãos, pois foi, de fato, destruída "em toda parte", como se declara no título da declamação (Queixa da Paz, 122-123). O lamento da Paz se volta contra os governantes: 
Entretanto, ó coisa indigna! Junto a eles não é possível encontrar sequer a sombra da verdadeira concórdia. Tudo é fingido e simulado; não há nada que não seja corrompido por facções escancaradas ou por divergências e rivalidades ocultas. No final, não encontro o trono da paz entre eles, mas antes é aí que mais estão as fontes e origens de todas as guerras (Queixa da Paz, $136-140) .^{40}$

A personificação da Paz amplifica a lamentação ao descrever suas decepções junto a diversas classes da sociedade: os eruditos, o clero secular, e mesmo entre aqueles que mais deveriam primar pela "perfeição da caridade", ou seja, que deveriam se destacar pela virtude e pelo exemplo aos demais, através da vida humilde no interior de um convento (Queixa da Paz, 184-189).

A Paz não encontrou seu lugar junto aos governantes nem junto à hierarquia eclesiástica, dos altos graus até os mais ínfimos. Nota-se a decepção para com a estrutura institucional da igreja. Essa lamentação ocupa considerável espaço dentro da declamação e parece ser o objeto principal da queixa, uma vez que outros setores da sociedade são mencionados em trechos comparativamente reduzidos, como é o caso da destruição da paz na família. Esta vitupera com veemência, sobretudo, contra os clérigos, bispos e papas, como é o caso de Júlio II, os quais, apesar do ofício eclesiástico, passaram para a história como guerreiros (Shaw, 1993, p. 15). Esse Papa havia inclusive conferido o estandarte da cruz aos suíços em recompensa dos serviços prestados à Santa Sé (Queixa da Paz, 520-540).

Tal recurso ocorre na peroratio construída por Erasmo, na qual se evoca não somente o principado ou o sacerdócio, mas também o povo (Queixa da Paz, 867-888). Deve-se pontuar, contudo, que sendo um texto escrito em latim, em uma época na qual grassava o analfabetismo significaria uma exclusão do povo. Potanto, a restrição do público-alvo àqueles que sabiam ler não exclui o apelo universal que a Paz se julga no direito de proferir. Esta é chamada a habitar em toda parte, muito embora tenha sido injuriada e perseguida.

\subsection{Conclusões do capítulo}

No capítulo segundo, caracterizamos o gênero declamação segundo Erasmo, definindo-o como um discurso fictício, escrito em prosa, com caráter de exercício da

\footnotetext{
${ }^{40}$ At, o rem indignam, apud hos nec umbram verae concordiae licuit cernere. Fucata fictaque omnia,factionibus apertis, clanculariis dissidiis ac simultatibus corrupta sunt universa. Denique adeo apud hos non esse sedem paci comperio, ut hinc potius omnium bellorum fontes ac seminaria (Erasmo. Queixa da Paz, 136-140).
} 
eloquência, cuja finalidade é simultaneamente educativa, no sentido de ser formativa do ponto de vista ético, ao aconselhar valores humanos condizentes com os ideais irênicos; e literária, ao apresentar-se como um divertimento, na medida em que procura comprazer o leitor através de formas elegantes e metáforas que visam provocar o riso.

Verificou-se que restaram ao menos onze declamações de autoria de Erasmo e que algumas se assemelham ao diálogo, por apresentarem mais de uma personagem que emitem discursos diretos reciprocamente direcionados. As declamações erasmianas divergem das senequianas e equiparam-se às gregas no sentido de que eram escritas integralmente, ou seja, tal como haveriam de ser pronunciadas. Em oposição a estas, estão as controvérsias de Sêneca, que eram redigidas de modo fragmentário e que possivelmente não eram lidas em voz alta da mesma forma que eram escritas, muito embora tivessem a finalidade de exercitar a actio, entendida como o exercício da modulação da voz, tal como a declamação mencionada em Cícero ou na "Retórica a Herênio".

A "Queixa da Paz" também apresentou traços característicos de outros gêneros antigos retomados pelos humanistas, tais como a oratória, o espelho dos príncipes, o panegírico, o tratado moral, a epístola suasória e o diálogo. Além disso, verificou-se que, de modo semelhante ao praticado nas declamações gregas, os humanistas apresentavam elementos do gênero epidítico e deliberativo: no primeiro caso, há elogios à paz tanto em suas autodescrições como na enumeração dos benefícios que esta concede aos mortais, mas também há trechos nos quais ela vitupera contra a guerra, seus propugnadores e os vários malefícios desta sobre os homens em particular e sobre a sociedade. Elogiar e vituperar configuram-se, então, como traços do gênero epidítico no discurso irênico da Paz. Contudo, o tema da paz é típico do deliberativo e alguns trechos apresentam uma forma de deliberação a favor de sua própria causa, apresentando os argumentos a favor da guerra somente na medida em que são imprescindíveis para a confutação ou o desaconselhamento. 


\section{CAPÍTULO 3 - A PERSONIFICAÇÃO DA PAZ}

O presente capítulo tem o objetivo de tratar da caracterização da prosopopeia realizada na "Queixa da Paz". A partir da análise sobretudo do exordium da declamação (1-29) e de outras partes que se fizerem pertinentes, o estudo visa a apresentar os traços da personificação por meio de seu próprio discurso, uma vez que esta declamação se caracteriza como um único discurso, o da Paz, e não apresenta qualquer narrativa introdutória em terceira pessoa.

\subsection{Declamação e personificação}

Para Erasmo, a prosopopeia é o discurso de um ente humanizado, uma personificação, que, estando longe, ausente ou morta, estabelece uma fala, um discurso direto (De copia, II, 389-397). Sua definição recupera a antiga tradição retórica presente em manuais e autores renomados, entre outros possíveis exemplos, como na "Retórica a Herênio" (IV, 53, 66). O exemplo de Platão como prosopopeia também está presente em Cícero (Fin, IV, 22, 61). Para Erasmo, uma prosopopeia deve parecer verossímil aos leitores (De copia, II, 388-389). Permite, ademais, tratar de assuntos sérios ou graves, sobretudo quando simula o discurso da pátria, da natureza, da república ou da província. Erasmo chega a citar as próprias "Catilinárias" e a locução de Sócrates no diálogo "Críton" de Platão para fundamentar seu ponto de vista (De Copia, II, 389-405). Para ele, a prosopopeia permite dar voz "muitas vezes aos próprios deuses, aos locais e a muitas coisas mudas com as quais ornamos o discurso" (De copia, II, 406-407). Convém, contudo, consignar que Erasmo não distingue entre uma prosopopeia, no sentido de uma pessoa ausente que toma a voz; e, uma personificação, entendida como uma abstração - como é o caso da paz - ou um objeto ou animal que usualmente não tem a habilidade da fala.

\subsection{Semelhanças com as personificações bíblicas}

Erasmo, além de leitor, tradutor e editor de escritos antigos, também era exegeta e teólogo, e, portanto, dispunha, para a invenção do corpus bíblico escrito em grego, em pleno período helenístico, ou da sua versão latina, a "Vulgata" revisada por Jerônimo, datada do século IV d. C.. Sem dúvida, estas fontes contribuíram para a forma de alguns trechos da “Queixa da Paz”. Em 1517, fazia cerca de um ano que ele havia publicado sua tradução para o 
latim do Novo Testamento grego, após um amplo trabalho de crítica dos manuscritos e seleção das variantes possivelmente mais originais, estabelecendo critérios ainda hoje utilizados nas edições críticas de escritos antigos.

No texto bíblico, entre outras significativas personificações abstratas femininas, tem-

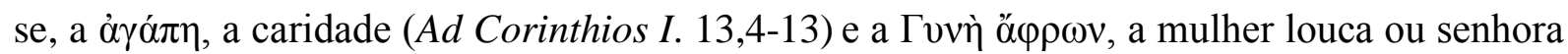
loucura (Proverbia. 9,13-18). Destaca-se, no "Livro da Sabedoria", escrito por volta do século II a. C., no Egito, o qual contém a personificação da sabedoria como uma mulher bela, uma mãe rica, fonte de ciência e "criadora" de todas as coisas, de uma forma semelhante à paz. Ela seria a antítese da Loucura, que seria a mãe de todas as maldades e contradições humanas. $\mathrm{O}$ autor bíblico imagina-se inclusive em desponsório com a sabedoria, a qual se enamorou de modo análogo a uma ninfa:

A sabedoria é radiante e imarcescível. Aqueles que a amam, a contemplam
com facilidade, e os que a procuram, a encontram. Ela se antecipa e se faz
conhecer aos que a desejam, quem madruga por ela, não se cansará, pois a
encontrará sentada à sua porta. Meditar nela é a perfeição da prudência; e, o
que vigia por sua causa, logo se encontrará sem perigo. Com efeito, ela vai à
procura dos que a merecem nos caminhos, mostra-se benigna e os precede em
cada pensamento. Seu verdadeiro princípio é o desejo da instrução; empenho
da instrução é o amor, e o amor, a observação das leis, mas a guarda das leis é
a confirmação da incorruptibilidade, a incorruptibilidade, verdadeiramente, faz
estar próximo de Deus; Portanto, o desejo de sabedoria conduz à realeza. Ó
tiranos dos povos, se vos deleitais com tronos e cetros, honrai, pois, a
sabedoria a fim de que reineis eternamente. Anunciarei-vos o que é a
sabedoria e como ela se originou, e não vos esconderei os mistérios, porém,
desde o início de sua origem, investigarei e farei manifesto o seu
conhecimento, e não me apartarei da verdade, nem farei caminho com inveja
corruptora, porque ela jamais comungará com a sabedoria (Sapientia. 6, 12-
23).

Outra personificação bíblica que certamente influenciou o caráter amável da Paz seria a caridade usada por Paulo, autor explicitamente citado na "Queixa da Paz" em seis trechos (169, 215, 710, 712, 735, 835). Esta está presente em uma de suas cartas redigidas originariamente em grego koiné. Nota-se que a antítese loucura-sabedoria utilizada por Erasmo no "Elogio da Loucura" pode ter, muito provavelmente, sua origem ou inspiração nos escritos sapienciais bíblicos, sejam veterotestamentários, sejam paulinos. A grande diferença, contudo, das ficções de Erasmo para com aqueles textos consiste no uso da primeira pessoa do singular numa estrutura de monólogo, no qual a personagem fala de si mesma e discorre 
longamente sobre o tema em questão, abrangendo inclusive a totalidade do discurso, e não somente alguns trechos.

$\mathrm{Na}$ literatura bíblica, além da primeira pessoa do singular, verificam-se descrições dessas prosopopeias abstratas na terceira pessoa do singular, o que é evitado no "Elogio da Loucura" e na "Queixa da Paz". Esta seria a grande novidade que Erasmo proporcionou à declamação enquanto gênero antigo recebido no Renascimento (Chomarat, 1981, p. 940; Kennedy, 1978, p. 85). Ao comentar genericamente as personificações da Loucura e da Paz, Kennedy (1978, p. 79) afirma que Erasmo "incorporou usos da voz e intensidade que romperam os limites da locução e as próprias barreiras linguísticas, transcendendo as convenções ciceronianas ou áticas que no período se procuravam associar”. Nesse sentido, rompeu os paradigmas bíblicos ao conceder a suas personificações simulação de um discurso direto, de um monólogo na integralidade do opúsculo. Diferenciam-se inclusive dos diálogos presentes em "Cântico dos Cânticos", com as personificações do amado e da amada, embora sejam apresentados em discursos diretos. Estas também se distinguem das declamações erasmianas, pois então em forma de diálogo, inclusive com a presença de outros personagens não protagonistas, e tais discursos diretos do casal não ocupam a integralidade do livro.

\subsection{As mulheres das "Heroides" de Ovídio}

Se, quanto à personificação simulada, a "Queixa da Paz" muito se assemelha a alguns trechos bíblicos, a forma de um monólogo inteiramente atribuído a uma prosopopeia feminina é encontrada, porém, nos poemas elegíacos das epístolas que Ovídio escreveu e denominou posteriormente como "Heroides". Embora esta não contenha personificações, convém aqui considerá-la. Trata-se de uma coleção de vinte e uma cartas de amor escritas e dirigidas a seus amados por personagens femininas da mitologia e da literatura, com exceção de três cartas que são dirigidas por homens às suas amantes. A ausência, o esquecimento, a distância, o abandono ou a perda funcionam como pontos de partida para que as heroínas dediquem cartas e se lamentem dos seus amores insatisfeitos por diversas causas. As heroínas procedem de diferentes mitos e gêneros literários, como os poemas homéricos, a tragédia, a lírica, a épica, entre outros. Ovídio adapta as personagens femininas à sua sensibilidade elegíaca, com a qual desenvolve o tema do amor, por exemplo, na epístola de Penélope, a qual expressa, em sua carta a Ulisses, sentimentos amorosos (Heroides, 1) apenas esboçados na "Odisseia”. Soto 
(2012, p. 52) nota que Ovídio caracterizou as amantes e concubinas de forma mais atraente e benévola que a empregada para descrever as esposas, que muitas vezes causavam problemas aos seus esposos. Esta ideia contrariava frontalmente a moral de Augusto, que visava, por meio de decretos, a proteger os "bons costumes" na sociedade romana. Soto (2012, p. 51) também nota que as personagens mitológicas caracterizadas por Ovídio correspondem mais às mulheres do seu tempo do que às próprias narrativas mitológicas. Ao comentar as "Heroides", observa Margolin (1971, p. 224, nota 8), os discursos diretos "aplicam as lições de retórica que ele [Ovídio] teria recebido junto aos mestres Aurélio Fusco e Porcio Latro. Ovídio não procura nelas a verossimilhança histórica. Elas pertencem à tradição das suasoriae". Verificaram-se referências de Erasmo às "Heroides" nos "Adágios", no "Panegírico a Felipe" (p. 42. 11. 538-543) e no "Sobre a redação de epístolas": é justamente no trecho desta terceira obra, cujo subtítulo Peculiaris epistolae character, em que Erasmo trata da caracterização das personificações, que se deu a referência às "Heroides", às quais não hesitou em chamar de "pequenas declamações" (declamatiuncula) (De conscribendis epistolis, p. 224, 11. 5-10). ${ }^{41}$

Em algumas das edições revisadas pelo autor, o exordium da declamação irênica de Erasmo é precedido pela indicação da pessoa que fala no monólogo declamatório: pax loquitur. Esse subtítulo visa a salientar que a declamação será feita pela própria $P a z$, que, personificada, se queixa, lamenta ou manifesta sua inconformidade com a injusta perseguição que os homens fazem contra ela, embora ela, por sua natureza benévola, seja capaz de comunicar aos homens todos os bens naturais e sobrenaturais, individuais e coletivos. Eis assim que a "Queixa da paz" se tornará, como o próprio Erasmo mais tarde afirmou, o "Epitáfio da Paz", tão rejeitada ao longo da História e, sobretudo, naquele início do século XVI (na Epístola a João Botzheim). Trata-se de um traço de ligação com a elegia, que teve início como canto fúnebre. $\mathrm{O}$ uso da personificação se baseava no princípio defendido pelo roterdamês: "a personificação é variável de diversas formas; o escritor pode selecionar a que deseja: que se deve fazer? Assim como é o homem, assim deve ser sua ação" (De Copia, I, 13). Esta teoria remonta à construção de caracteres ( $\tilde{\hat{\eta}} \theta 0 \varsigma)$ já presente nas poéticas de Aristóteles (Poética, 6, 12-15) e Horácio (Ars Poetica, 153-178).

\footnotetext{
${ }^{41}$ Margolin (1971, p. 253, nota 6) também visualizou uma referência indireta às heroidas no seguinte trecho: "In hoc argumenta poterit et illud admoneri, blandiorem oportere flngi epistolam, quam adolescens adolescenti, congerro congerroni, amans scrihit amanti” (Erasmo. De conscribendis epistolis, p. 253, 11. 5-7); como também no seguinte trecho ao se falar do retorno de Ulisses à proximidade de Penélope descrita nas Heroidas de Ovídio: "Quum ad vxores ventum est, tum jiunt senese" (Erasmo. De conscribendis epistolis, p. 269, 1. 17)
} 


\subsection{Personificações femininas}

Chomarat (1981, p. 1000) afirma que a personificação da Paz possui duas características essenciais: é feminina e abstrata. Isso não somente porque pax em latim é um substantivo feminino, mas por sua própria caracterização por Erasmo. Aristóteles apontou que há caracteres adequados e distintos à personificação masculina e à feminina: "sem dúvida existem caracteres viris, entretanto a coragem desta espécie de caracteres não convém à natureza feminina" (Poética, 15, 4). Se o Estagirita aponta a coragem como um elemento próprio ao homem, para Mendelson (1994, p. 94), Quintiliano recomendava que a actio considerasse no caráter da personificação que falava e em seu auditório alguns fatores relevantes, como o número de ouvintes, seu status, nacionalidade, sexo, idade, partido e, acima de tudo, seu caráter moral (Instituição Oratória, III, 8, 37-38). Também no "De copia" (II, 384-389) ele se refere à consideração do gênero da pessoa que emite o discurso. Deste modo, verifica-se que o recurso à caracterização do feminino é um fator relevante dentre as estratégias de persuasão exploradas por Erasmo ao personificar a Paz como uma sábia e compassiva mulher (Spierling, 2008, p. 119) que se dirige a todos os mortais para convencêlos das vantagens individuais e sociais da paz, apresentando razões naturais, tais como a incompatibilidade entre a natureza e a guerra e as consequências inconvenientes da guerra no plano político e sócio-econômico. Do ponto de vista religioso, a guerra não corresponde ao ideal da cavalaria medieval e da propagação da fé. Erasmo denuncia a incoerência com a doutrina cristã por parte de bispos e pregadores agentes da guerra, ainda que por motivos “justos" ou "santos", mas muitas vezes insignificantes.

Embora a personificação erasmiana não seja uma prosopopeia feminina, isto é, representasse a ficção de uma mulher "em concreto" - como encontramos nas "Heroides" -, mas sim de uma abstração ou alegoria, como no caso da paz ou da loucura ou, por exemplo, como encontramos em Cícero, ao atribuir uma voz à pátria e à república no início das "Primeiras Catilinárias" (7,18; 11, 27), é justamente nesse ponto, entre outros, que encontramos mais uma inovação na declamação erasmiana.

Erasmo escreveu várias de suas obras tendo a figura da mulher dentro do contexto do matrimônio, seja na fase anterior (virgens), durante este (casadas), ou posterior (viuvez) tais como o "Elogio do matrimônio" (1518); o "Pretendentes e meninas" (1523), o "Virgem misógama" (1523), o "Virgem penitente" (1523), o "Esposa mempsigama ou casamento" 
(1523) e alguma trechos do "Instituição do matrimônio cristão" (1526). Sua declamação "Elogio do matrimônio" e o seu tratado sobre a viuvez, assim como vários de seus colóquios, lidam com a virgindade, o namoro, o casamento, a criação de filhos e a viuvez (Chomarat, 1981, p. 894), assuntos que tocam diretamente em questões da relação entre os gêneros masculino e feminino. Sowards (1982, p. 88) apresenta alguns pontos específicos na concepção erasmiana acerca da mulher: a necessidade de lhes prestar a educação em conformidade com os humanistas italianos que julgavam ser esta essencial para uma formação moral que preserve a virgindade pré-matrimonial, além disso, compreendia a liberdade da mulher na escolha do cônjuge. Este enfoque em questões de castidade deve-se às discussões acerca da exaltação do celibato sobre ao matrimônio, que Erasmo confuta promovendo um elogio e uma suasória do matrimônio (Leushuis, 2004, p. 1287-1307). Se, de um lado, a Paz se reveste dos caracteres femininos, Erasmo também cita uma frase paulina afirmando que não se pode fazer distinção "entre grego e bárbaro, entre homem e mulher", onde se nota abertura para a consideração de certa igualdade entre os gêneros: “A partir daí, não há mais servos e homens livres; bárbaros e gregos; homens e mulheres; mas todos são o mesmo em Cristo, que tudo conduziu à concórdia" (Queixa da Paz, 369-370).

Em alguns trechos escritos por Erasmo há a transcrição de alguns estereótipos do sexo feminino.

O sexo feminino é afligido por dois vícios. Elas vivem para agradar na aparência. Este desejo é originário na vanglória. Segundo, elas não podem tolerar injúrias e são propensas à vingança. Isso se deve à fraqueza dos seus intelectos e à sua ignorância para com a verdadeira nobreza. Uma mente realmente nobre releva a injúria... Ademais, como a mulher é levada pelas emoções, elas medem a honra pelos padrões exteriores e não podem tolerar ser superadas nessas matérias (Epistola V, p. 704, F-5A).

Se Erasmo afirma a "peculiar inconstância da mulher" (De Copia, II, 758), reconheceo mesmo em relação à criança, ao povo e inclusive ao próprio homem. Para Rummel (1996, p. 4), o holandês reproduz em seus escritos os defeitos dos estereótipos masculino e o feminino. Os homens são como feras, mas, como estão no controle patriarcal, são mimados, facilmente enganados. A mulher é rancorosa, vã, ignóbil, atrasada intelectualmente e manhosa, mas tal leitura do texto, conforme a própria autora claramente se propõe a explicar, deve ser entendida no gênero próprio dos textos erasmianos sobre o matrimônio que abordam os dois lados da questão, embora tais estereótipos sejam por vezes refutados logo em seguida por ele. Leushuis (2004, p. 1288) também constata que as 
declamações erasmianas que tratam do casamento apresentam probatio e confutatio a favor da instituição. Entretanto, apesar do comprometimento de Erasmo para a defesa do matrimônio, o autor, submetido à forma do gênero, não deixa de apresentar, por exemplo, em uma carta de genere dissuasorio, uma lista de argumentos teológicos contra o matrimônio, como a virgindade e o celibato como meios de felicidade e o desejo sexual como pecado, assim como alguns prejuízos do contato entre os gêneros. Se o matrimônio é uma armadilha, a mulher seria um ser trapaceiro que envolve o noivo em seus laços (2004, p. 1288), mas convém entender tais afirmações como os argumentos que Erasmo pretende refutar a ponto de, além do elogio à beleza, à gentileza das francesas e a Margareth More, nos próprios escritos sobre o matrimônio, a mulher também ser apresentada como mais do que uma companheira agradável:

O que é, pois, mais doce do que viver com uma mulher com quem tu estás mais intimamente ligado não apenas pelos laços de afeto, mas também pela união física? Se tirar o grande deleite espiritual da bondade dos outros parentes próximos e conhecidos, como é muito mais agradável ter alguém com quem compartilhar os sentimentos secretos do coração, com quem tu podes falar como consigo mesmo? Com essa lealdade obtens segurança, com quem conduz as tuas fortunas como próprias. Que felicidade existe na união de marido e mulher. Em comparação com isto naõ existe nada maior nem mais duradouro em toda a natureza! Enquanto estamos ligados com os nossos outros amigos pela benevolência do espírito, com uma esposa estamos unidos pelo maior carinho, pela união física, pelo vínculo do sacramento e pela partilha comum de todas as fortunas (De conscribendis epistolis, Collected Works Erasmus, 25, p. 139).

Basta ler o exordium da "Queixa da Paz" para a clara percepção de que o feminino caracterizado pelo roterdamês se coaduna com uma visão positiva da mulher e não com o estereótipo negativo utilizado por ele nas confutações retóricas de alguns trechos de seus escritos. Dificilmente se podem esperar demonstrações inequívocas sobre questões complexas, como o papel da mulher, de um homem que afirma que "assuntos humanos podem tomar tantas formas que respostas definitivas não podem ser fornecidas para todos eles" (Rummel, 1996, p. 12; Terpstra, 1997, p. 696). Margolin (2000, p. 10), com argumentos análogos, demonstra como os elogios e as críticas à mulher presentes nos escritos de Erasmo não podem ser inferidos como seu "pensamento explícito", devido à transposição do eu discursivo para uma personificação diversa do autor e que era própria do gênero literário por ele utilizado. 
Entretanto, estas afirmações, ao levarem em conta apenas os escritos sobre o matrimônio e a personificação da Loucura, podem não ter explicitado a caracterização do feminino presente na "Queixa da Paz", que apresenta exatamente as qualidades contrárias ao estereótipo dos defeitos da mulher: a Paz é amorosa, sábia, sublime, intelectualmente superior aos homens e delicada. É a mulher perfeita, que oferece a si mesma para o benefício da humanidade. Ela é imortal, face aos homens mortales. Representa a mulher em seu esplendor, conforme os critérios do que era considerado belo naquele contexto histórico. Veremos, ademais, que, além de mulher, a Paz figura de um modo tão elevado, que mais se assemelha a uma ninfa ou a uma deusa, embora mantenha seus caracteres femininos segundo os moldes predominantes no século XVI, adaptando seu êthos ao que o público espera de quem argumente sobre ela. Sloane (2004, p. 113), ao comentar os antigos fundamentos retóricos para os autores do Renascimento, escreveu:

Em termos retóricos, a questão gira em torno do êthos, ou seja, os meios pelos quais um falante ou escritor projeta uma autoimagem. É bem sabido que a absorção com a retórica - uma arte sobre a qual os pagãos como Cícero tinham muito a dizer - é uma das marcas do humanismo renascentista. Êthos, identidade ou individualidade é um princípio fundamental da retórica. E caráter por sua vez foi um dos principais temas do próprio Renascimento, um período em que personalidades altamente individualizadas colocaram seu selo sobre as maravilhas artísticas e intelectuais da época. O Renascimento foi um tempo, por outro lado, em que a autoconstrução tornou-se possível, em que o passado e a linhagem se tornaram um pouco menos funcional ou louvável do que a identidade que cada um era capaz de forjar para si mesmo. Autoconstrução, bem como o ethos, capturou a imaginação dos leitores - por meio de peças de prosa curtas chamadas "caráteres", através das "Caráteres" recém-impressas de Teofrasto, através da retórica revivida de Aristóteles, com sua descrição de várias personagens que o orador pode encontrar em sua audiência. Como estes últimos exemplos indicam, êthos, em particular, teve uma aplicação prática e comunicativa (Sloane, 2004, p. 113).

O discurso de uma personagem feminina não ocupa somente algumas partes do discurso como em algumas das antigas declamações, mas de modo semelhante às "Heroides", ocupam a totalidade do discurso. O discurso inteiro, ao menos no "Elogio da Loucura" e na "Queixa da Paz", são característicos de uma personificação feminina. Vejamos agora, por meio de alguns trechos do discurso, como a Paz se caracteriza, como ela delineia seu próprio êthos retórico.

Já no exordium (Queixa da Paz, 18-21), percebe-se não somente a divindade e o feminino, mas também o exercício das típicas funções maternas: "fonte, progenitora, 
aleitadora, fomentadora". Note-se que não somente substantivos e adjetivos deste gênero são utilizados para a caracterização da paz. O discurso está coerente com o caráter feminino, sobretudo, pela atribuição da maternidade, mais especificamente, com o ato de amamentar ou nutrir, assim como o ato de tutelar ou cuidar, que naquele tempo era praticado quase exclusivamente pela figura feminina, dentro da estrutura familiar típica da Antiguidade. Se o uso de substantivos com a terminação trix pertence ao gênero feminino, nos substantivos utilizados por Erasmo, nota-se ademais o campo semântico da maternidade. Essa Paz se volta ao homem suplicante pelo dom da concórdia, demonstrando como ela nutre, alimenta, protege e enriquece o homem, que é tratado como uma espécie de filho pequeno, lactente e dependente. A Paz de Erasmo é, pois, uma verdadeira mãe. Esta também é sedutora, perspicaz, argumentiva, o que se coaduna exatamente com a finalidade da retórica: persuadir.

Os trechos que elevam o feminino contrastam com oque vitupera o masculino. Se este é honrado, lento, forte, reflete o antigo ideal medieval de cavalaria, ou mesmo da combatividade masculina dos antigos heróis da Grécia e de Roma. Erasmo, porém, ironiza essa espécie de honradez que defende ideal da guerra. Afronta demonstrando que a masculinidade atrelada ao heroísmo, agravada pelo fato de ser praticada por homens já maduros, está ligada a um caráter sanguinário, contrário à própria natureza humana, essencialmente, pacífica:

Até aquilo que outrora era consenso entre os pagãos, de que não se devia cobrir os cabelos brancos com um elmo, como diz o poeta, esse costume hoje, entre os cristãos, tornou-se motivo de louvor. Para Nasão, é coisa infame um soldado velho, enquanto, para estes, ser um guerreiro septuagenário é algo magnífico! (Queixa da Paz, 474-476).

É justamente o contrário do ideal de cavalaria das "Chansons" ou mesmo da "Morte do Lidador" de Alexandre Herculano, entre outras manifestações ideológicas presentes na literatura do Romantismo: o idoso "honrado" pelo fato de ir à guerra, apesar da idade. O combatente idoso é aqui uma figura indigna, merecedora de sátira ou vitupério. Já a Paz é caracterizada como mãe, procura proteger seus filhos, os mortais, pois "não há nada mais infeliz para os homens do que ela [a guerra]" (Queixa da Paz, 25). Na terceira parte da obra, em conformidade com a tradição retórica grega (Retórica, 1360a), Erasmo desenvolve argumentos de conveniência econômica ou de honra para a manutenção da concórdia. A maternidade desta se exerce ao garantir o bom desenvolvimento da sociedade. Voltaremos a esse ponto, ao tratarmos da Paz enquanto sábia e proficiente em assuntos práticos como 
economia, política e diplomacia. Se de um lado esta é caracterizada como mulher, deve-se observar que a declamação de Erasmo também a caracteriza como uma divindade, uma deusa.

\subsection{A deusa Pax}

Para Cícero (De natura deorum, II, 70), os deuses e deusas estavam caracterizados de modo a representar as paixões e os temperamentos humanos. Afrodite, por exemplo, era a mais bela das deusas, aquela que se deixa levar pelo amor, pelo poder da beleza e pelos impulsos da sexualidade (Ibid., II, 69). Perséfone é aquela atraída pelo mundo espiritual, misteriosa, mística, que vivia dividida entre o mundo sensível e o superior e capaz de ser macabra e ter pensamentos sombrios (Ibid., II, 66). Ceres é a deusa mãe, que se deleita com as crianças, exalta a geração da vida, de sentimentos, emoções e experiências. É a deusa do cereal, a nutriz e a mãe (Ibid., I, 40). Juno seria a mulher do poder, a irmã e esposa de Zeus. Ciumenta, vinga-se em filhos de outras mulheres ou nos espectadores. Embora estabeleça relações de fidelidade e lealdade, reage à frustações com ira e não com depressão (Ibid., II, 66). Vesta, permanecendo virgem, revela a mulher em um espírito de integridade. Atena, deusa da sabedoria e da vitória, é prática, desinibida e segura (Ibid., II, 67). Diana, a deusa atlética, ama e protege a natureza (Ibid., II, 68-69). Nesse sentido, a mitologia seria uma espécie de catálogo de caracteres. Essas paixões estavam em harmonia com os seus atos, de modo que muitas vezes imitavam as paixões humanas, fossem as boas, chamadas virtudes, fossem as más, chamadas vícios. Assim, as deusas possuíam seu próprio $\tilde{\eta} \theta$ o $\varsigma$ (caráter). Seu $\tilde{\eta} \theta$ o s admitia as paixões e as ações harmônicas, como preceituavam as normas das antigas poéticas (Aristóteles, Poética, VI, 12-15; Horácio, Arte Poetica, 153-178). Van der Poel (1987) concebe que os critérios horacianos sobre a caracterização das personagens foram influentes e determinantes nas declamações renascentistas.

Observe-se, então, a deusa Pax, correspondente à deusa grega Eîńv $\eta$. Esta foi reconhecida oficialmente como deusa no governo de Otávio Augusto, que edificou no Campus Martius o templo chamado de Ara Pacis e outro chamado de Forum Pacis. Desse modo, não havia sido objeto de culto oficial no período republicano. Filha de Júpiter e da Iustitia, era representada com um ramo de oliveiras, um cetro e uma cornucópia, símbolos associados à primavera, época da florescência, da harmonia e da abundância. Nota-se que Erasmo, ao caracterizá-la em seu exórdio parece ter claramente a figura dessa deusa greco- 
romana em sua imaginação, sobretudo ao afirmar que nada floresce no mundo sem a proteção da paz (Queixa da Paz, 1-29). A imagem da cornucópia torna-se evidente no seguinte trecho: “sem mim, não há nada que floresça em parte alguma; sem mim nada é seguro, nada é puro ou santo, e nada é alegre para os homens ou agradável aos céus" (Queixa da Paz, 20). Nos antigos, seu caráter era descrito como gentil (Epigrama atribuído a Homero, 15), doce (Greek Lyric V Anonymous. Fragmento 1021), administradora das riquezas da humanidade (Píndaro, Odes olímpicas, 13, 6ss), por fim, a deusa da prosperidade (Virgílio, Georgicae, 2, 425ss). À Paz, juntamente com a Justiça e a Lei, cabe "vigiar as obras dos mortais" (Hesíodo, Teogonia. 901-903). Como veremos mais detidamente, Erasmo caracteriza a Paz "louvada a uma só vós pelos deuses e pelos homens" (Queixa da Paz, 17), ora como uma deusa, ora como uma musa ao modo antigo, pois a pax fala se si mesma como necessária em relação ao humanocontigente (Queixa da Paz, 20-21).

Além da relação da deusa latina Pax com a grega Eîńin, a Paz conclama sua audiência como mortales, entendido basicamente como uma forma de denominar a raça humana, mas que, no contexto, insinua uma oposição a sua própria imortalidade (Queixa da $P a z, 259-260)$. Se os homens são mortais, a Paz os trata como tal, afirmando-se como imortal, pois tal como na concepção antiga, somente os deuses podem ser imortais (Cícero, De natura deorum, II, 153). Outro exemplo desse lugar comum é encontrado em Salústio, que costumava usar este vocábulo para a diferenciação dos homens em relação às bestas e aos deuses (Salústio, Bellum catilinae, 1, 5). Por outro lado, há a concepção cristã predominante no século XVI, de que somente as criaturas espirituais podem ser imortais, tais como a alma humana, o ser angélico e a essência divina, em conformidade com o cristianismo através de numerosas passagens do Novo Testamento (Cf. Matheus 10,28; Acta Apostolorum 2,27).

Quando Erasmo utiliza esta expressão no contexto cristão, parece querer exaltar a figura do que fala, no caso, da Paz, uma vez que, ao chamar aos homens "mortais", ela se exclui desse conjunto, e, como a imortalidade é uma característica divina, sugere os termos de sua superioridade, conferindo-lhe autoridade para invectivar de quem quer que seja, ainda que sejam altos dignitários, eclesiásticos ou mundanos. Chamar de mortais seria, então, uma maneira muito suave de entendê-la como dotada de uma autoridade divina. A Paz toma o papel da origem da benevolência como ser divino que infunde sentimentos misericordiosos de uns para com os outros, tal como a divindade cristã. Para isso utiliza a anáfora: “...sem mim, 
não há nada que floresça em parte alguma; sem mim nada é seguro, nada é puro ou santo, e nada é alegre para os homens ou agradável aos céus” (Queixa da Paz, 20).

Desprende-se, além disso, em outro trecho a dependência do homem apontada pela pax. A noção de contingente e necessário, no cristianismo, é análoga à do homem para com Deus. Se aquele depende da Paz, ela é uma deusa. Esta é quem faz florescer, quem torna tudo puro e santo, quem torna qualquer coisa que ja agradável aos céus. Não sem razão, logo no exordium, esta atribui a si mesma a honra de ser louvada pelos deuses e pelos homens como administradora dos bens celestiais e terrenos (Queixa da Paz, 18-21).

A deusa Paz ousa tratar o próprio Cristo como seu arauto ou mensageiro: "Cristo fora enviado por minha causa e tomava conta de mim" (Queixa da Paz, 240-241). Nesse ponto, a Paz afirma ter sido anunciada por Cristo. Ao tomar a natureza divina, usa a autoridade dele para se dignificar, pois os cristãos, sobretudo em uma sociedade que ainda não havia se cindido com as variantes confessionais da Reforma, acredita que Jesus era um ser misteriosamente idêntico e distinto de Deus Pai. Este teria encarnado para anunciar o Pai, mas a Paz se afirma como anunciada por ele. Esta se identifica, então, com o próprio ser que deveria ser anunciado. Esta também se apresenta com a missão dele, enquanto pacificadora e mediadora, pois o próprio sacrifício da missa, para ser bem aceito pela divindade, deve ser oferecido em seu nome:

Quando ordena que a oferenda seja depositada no altar e que não seja oferecida, senão depois da reconciliação com o irmão, porventura não ensina abertamente que a concórdia deve anteceder a todas as coisas e que nenhuma oferenda é agradável a Deus se não for recomendada por mim? (Queixa da $\mathrm{Paz}, 318-322)$.

Nota-se a insinuação de referir-se ao sacrifício da missa e comparar o papel da Pax ao de Cristo. Justifica-se esse artifício no lugar da explicitação clara e direta devido à interpretação que alguns cristãos costumavam ter em comparações com a pessoa de Cristo, considerada pela teologia católica como intocável e incomparável. Insinuar sem afirmar era necessário para proteger-se contra possíveis invectivas de teólogos ávidos de inúteis e rancorosas controvérsias teológicas lamentadas pela Paz. Em oposição à supracitada referência a duas suasórias senequianas (Suasória, I, II e IV), nas quais encontram as questões da guerra e dos combatentes como sujeitos de uma causa honesta. Diante da honorabilidade da guerra não é dimimnuída nem pelo poder do augúrio ou pela verdade de fé. Entretanto, 
Erasmo procura tratar a paz como uma causa honesta, respandando-se na Bíblia contra aqueles que querem a guerra. Desse modo, enfraque o argumento jurídico, filosófico e teológico da "guerra justa" com o poder da retórica..

\subsection{A Paz enquanto sábia}

Não é de se estranhar que em sua caracterização, a Paz, além de feminina e "divina", seja delineada como sábia. De fato, esta desenvolve os seus argumentos políticos em seu próprio favor. Nota-se a amplitude de aspectos abordados por ela a fim de reforçar o argumento, tal como recomendava Aristóteles na defesa de uma causa nos discursos deliberativos:

Quanto à paz e à guerra, é preciso conhecer o poder da cidade, quanta força já tem e a quanta pode chegar, a natureza das forças que tem à sua disposição e as que pode acrescentar; e, além disso, que guerras travou e como planejou. É necessário saber estas coisas não só sobre a própria cidade, mas também sobre as cidades vizinhas. É necessário ainda saber com que povos se pode esperar fazer a guerra, a fim de manter a paz com as mais fortes e fazer a guerra contra as mais fracas. É também necessário saber se os recursos militares da cidade são iguais ou desiguais aos dos vizinhos, pois nisto também pode ser superior ou inferior. Além disso, é necessário ter estudado não só as guerras da própria cidade, mas também as das outras em função dos seus resultados, pois de causas semelhantes resultam efeitos semelhantes (Retórica, I, 4, 9).

Tais lugares comuns sugeridos por Aristóteles e recorrentes em diversos autores antigos são utilizados pela Paz, entre os quais destaca-se logo de início o argumento que ocupa a primeira sessão, segundo o qual os animais devem ser imitados como exemplo, uma vez que os homens providos de razão não se comportam como tal, mas sim como se presume dos irracionais (Queixa da Paz, 45-50).

Se na Antiguidade a piedade para com os deuses era um lugar-comum útil para defesa de uma causa (Aristóteles, Retórica, I, 2, 8), Erasmo aplica tal recurso retórico à cultura cristã utilizando-se de referências dos Evangelhos a Cristo como modelo a ser emulado (Queixa da $P a z, 261-268)$. A Paz não somente o relembra como exemplum, mas traz elementos da história greco-romana a serem admirados pelos seus leitores, a fim de evitar-se os conflitos armados (Queixa da Paz, 618-621). Partindo dos argumentos de natureza religiosa para os práticos, esta ousa apresentar motivações econômicas a favor do irenismo, completando assim sua oniciência acerca de várias áreas do conhecimento (Queixa da Paz, 782-797). 
A segunda estratégia de Erasmo para caracterizar a pax como apta a aconselhar os homens em seus negócios políticos, sobretudo em defesa de si mesmo, seria que este é violento contra sua própria raça. A sabedoria desta se demonstra também pelos argumentos deliberativos que estimulam ações concretas para a manutenção da concórdia e para evitar a guerra. Deve-se salientar, ademais, a proposta de um esquema jurisdicional entre os príncipes europeus a fim de resolver conflitos dinásticos, territoriais e políticos (Rodrigues, 2012, p. 275-276).

Segundo Mack (1993, p. 307-308), ao comentar o De Copia, a analogia que é possível identificar nos argumentos apresentados pela Paz em seu favor está presente em alguns dos paradigmas que Erasmo propôs. Colocaremos em paralelo esses métodos com alguns dos argumentos retóricos apresentados:

\begin{tabular}{|c|c|}
\hline Princípio do De Copia, 1, 6 & acia na Querela \\
\hline $\begin{array}{l}\text { Após afirmar sumariamente, } \\
\text { prosseguir } \quad \text { com } r \text { uma } \\
\text { explicação mais } \quad \text { ampla } \\
\text { (75A) }\end{array}$ & $\begin{array}{l}\text { O tema do livro está explícito em seu título quando se fala } \\
\text { que a Paz foi rejeitada e perseguida em toda parte pelas } \\
\text { nações. Demonstra-se cada parte dessa proposição ao longo } \\
\text { da Queixa da Paz. }\end{array}$ \\
\hline $\begin{array}{l}\text { Enumerar singularmente as } \\
\text { causas do argumento (77A) }\end{array}$ & $\begin{array}{l}\text { A Paz enumera as consequências maléficas da guerra e as } \\
\text { suas próprias benesses, como por exemplo, ao confrontar o } \\
\text { incremento da cultura e da economia proporcionados por sua } \\
\text { influência, e o declínio das duas, durante a guerra. }\end{array}$ \\
\hline $\begin{array}{l}\text { Perseguir as causas mais } \\
\text { elevadas }(77 \mathrm{C})\end{array}$ & $\begin{array}{l}\text { A Paz acredita que a guerra nasce nos corações humanos } \\
\text { através da discórdia dos interesses egosísticos, sobretudo, de } \\
\text { certas classes mais influentes, mas também é sustentada com } \\
\text { argumentos incoerentes com a pietas cristã e o ensinamento } \\
\text { pacífico de Cristo. }\end{array}$ \\
\hline $\begin{array}{l}\text { Enumerar as causas que } \\
\text { corroboram com } \\
\text { argumento }(77 D)\end{array}$ & $\begin{array}{l}\text { A Paz enumera as diversas consequências da guerra, como o } \\
\text { estupro, a peste, a decadência moral e econômica, entre } \\
\text { outros, mas também enumera as benesses de sua lavra como } \\
\text { a ordem, a tranquilidade, a prosperidade e a concórdia } \\
\text { universal. }\end{array}$ \\
\hline Propor e colorir com ricas & Erasmo descreve coisas, lugares, pe \\
\hline
\end{tabular}




\begin{tabular}{|c|c|}
\hline $\begin{array}{l}\text { descrições a favor do } \\
\text { argumento (77E) }\end{array}$ & $\begin{array}{l}\text { históricos a fim de convencer seu leitor, como por exemplo, } \\
\text { ao descrever a Paz entre os animais ou na república romana, } \\
\text { ou ainda, entre os anjos, ao passo que apresenta a guerra } \\
\text { entre os demônios, os eruditos e os religiosos, assim como } \\
\text { se refere aos tempos de Roma, ao passado próximo da } \\
\text { guerra dos últimos doze anos, entre outros. }\end{array}$ \\
\hline $\begin{array}{l}\text { Incluir digressões quando } \\
\text { conveniente }(77 \mathrm{~F})\end{array}$ & $\begin{array}{l}\text { É possível identificar diversas digressões na declamação, } \\
\text { tais como: sobre a natureza dos animais, a legislação de } \\
\text { sucessão, as consequências econômicas, entre outras. }\end{array}$ \\
\hline $\begin{array}{l}\text { Amplificar } \\
(77 \mathrm{G})\end{array}$ & $\begin{array}{l}\text { A amplificação também é um recurso utilizado pela Paz } \\
\text { como no caso de citar os diversos animais que são capazes } \\
\text { de viver em harmonia. Erasmo também amplifica o assunto } \\
\text { de Cristo Pacífico ao trazer à tona diversas passagens } \\
\text { irênicas atribuídas a Cristo. }\end{array}$ \\
\hline
\end{tabular}

A sabedoria da deusa Paz também compreende a arte retórica que através da sua declamação, tal como os antigos rétores, apresenta seu discurso como um modelo de suasória a favor da paz e vitupério contra a guerra.

\subsection{A Paz enquanto teóloga}

Erasmo utiliza argumentos teológicos na "Queixa da Paz" de forma separada e complementar, dedicando uma sessão deles aos de origem bíblica e outra aos de inspiração antiga. Hoffman (1994, p. 227) defende a hipótese de que ele tratava desses assuntos cristãos inclusive com as antigas técnicas retóricas:

Nosso estudo sobre a hermenêutica bíblica demonstrou como ele introduzia a retórica a serviço da teologia. Utilizava o método alegórico e tropológico de forma a coordenar cristologia, eclesiologia e ética em um único caminho humanista. Seu método exegético não somente revela seus princípios hermenêuticos, mas também sua teologia retórica.

Ele, por exemplo, coloca o "Cristo pacífico" como exemplo a ser seguido pelos leitores. Se este se diz cristão, deve zelar pela paz da mesma forma como Jesus o havia recomendado aos seus discípulos. Nota-se, porém, que no caso da Queixa da Paz, o holandês 
não usa as passagens da Bíblia de modo a fazer uma verdadeira exegese, como o realizou nas diversas edições e traduções dos escritos antigos e bíblicos, mas delimita alguns trechos para defender o ponto de vista irênico, refutando alguns passos, sobretudo do Antigo Testamento, que servem de fundamento para seus opositores e de incômodo para seu argumento. É justamente nesses pontos que a Paz estabelece uma confutação (Queixa da Paz, 253-259).

A Paz antepõe o Deus dos judeus com o Deus dos cristãos, como forma de refutar o Antigo Testamento com passos do Novo, comportamento que se insere no contexto mais amplo como ponto inequívoco da teologia cristocêntrica de Erasmo, de que não trataremos na presente dissertação por tema e pertinência. Ele parte de uma expressão típica das canções medievais de exortação à "guerra santa" inspiradas em excertos do Antigo Testamento como a referência ao Deus dos Exércitos (Queixa da Paz, 224-236).

Erasmo não discute diretamente a natureza da expressão "Deus dos Exércitos". Prefere passar pela questão sem aprofundá-la com longas digressões filológicas e teológicas, como os teólogos costumavam fazer nas questões sobre a guerra justa, ao discutir as passagens a favor e contra a guerra presentes na Bíblia (Cf. Isaías 32,18; Salmo 124,5; Salmo 127,6; Gálatas 6,16; Isaías 52,7). Chomarat (1981, p. 938) aponta a necessidade de sobrevivência no meio político e eclesiástico no qual Erasmo atuava como erudito como motivo significativo para a escolha de um gênero que poderia dar liberdade para falar sem ser censurado ou punido, embora as reações contrárias ao "Elogio da Loucura" mostrem que ele não estava totalmente imune. Ao comentar a caracterização da personagem emissora do discurso, Sloane (2004, p. 116) afirma: "tratava-se de algo como uma máscara para o autor".

A personificação da Paz também seria uma espécie de camuflagem para Erasmo, pois, embora não se saiba se Erasmo previa que os teólogos se voltariam contra seu irenismo, é certo que, após a publicação desse escrito, somado sem dúvida aos acontecimentos e polêmicas posteriores contextualizados na Reforma, ocorreram reações contra a "Queixa da Paz” especialmente na Espanha e na França.

No primeiro país, Zuñiga teria encontrado trechos "luteranos" (Bataillon, 2007, p. 124). No que se refere ao segundo, Telle (1978, p. 35) aponta que esta declamação irênica reacendeu justamente a célebre controvérsia teológica "acerca de guerra justa" atacada por Erasmo e por outros teólogos católicos (Ibid., p. 33), inclusive protestantes como Calvino 
(Ibid., p. 36), e defendida pelos teólogos e juristas da Universidade de Paris. A polêmica chegou a tal ponto que a tradução francesa da Querela publicada por Chevalier de Berquin foi censurada pela Faculdade de Teologia da Sorbonne em $1^{\circ}$ de junho de 1525 (Ibid., p. 32) e renovada em 1527 (Phillips, 1971, p. 247).

Não era a primeira polêmica de Berquin. Antes de traduzir para o francês as obras de Erasmo, ele havia se dedicado às obras de Lutero (Bataillon, 2007, p. 153). Também não era a primeira polêmica de Erasmo com os teólogos da Sorbonne, pois já havia disputado com estes por ocasião das suas traduções bíblicas (Rodrigues, 2012, p. 338). Não se deve desconsiderar, ademais, os inconvenientes políticos que a defesa da paz poderia fazer surgir com os príncipes cristãos, tais como Henrique VIII e Francisco I, ciosos das incursões militares e célebres pelos seus feitos guerreiros (Telle, 1978, p. 35).

Erasmo, com sua "Queixa da Paz", entrava em conflito direto e em plena polêmica com teólogos escolásticos e com políticos influentes e beligerantes, a ponto de se verificar a condenação sistemática da Universidade de Lovaina contra toda sua obra literária e a mudança de Erasmo para Basileia, Suíça (Moya Bedoya, 2008, p. 203). Se não se pode conceber que o roterdamês teria previsto as controvérsias suscitadas pelos seus escritos, inclusive por uma de suas traduções, não seria exagero afirmar que este expunha os príncipes e sua hipocrisia de um modo incisivo, convincente e, em certos trechos, satírico.

Deve-se, por fim, considerar que, na Queixa da Paz, Erasmo não é um pacifista a ponto de negar qualquer forma de conflito armado (Kinsella e Carr, 2007, p. 55-56). Sua prática de expor em seus escritos "utramque partem", ou seja, os dois lados da questão (Remer, 1994, p. 313), como correu no caso da guerra entre os cristãos, considerada cruel, e a guerra dos cristãos contra os turcos, considerada justa, além de muitos fatores, sobretudo quando este assume posições "humanistas-cristãs", contribuiu para que sustentasse a fama de vir duplex, tal como o alcunhou Lutero (Weiler, 1997, p. 11).

Em termos teológicos, pouca diferença se verifica entre os teólogos pregadores das cruzadas contra o islã nos séculos XII e XIII e alguns trechos do escrito de Erasmo que argumenta acerca da oportunidade da guerra contra os turcos e da sua inconveniência entre os cristãos. (Queixa da Paz, 681-685). 


\subsection{A Paz enquanto vítima}

Essa mãe zelosa, sábia, divina, apresenta-se também como vítima da guerra e do instinto sanguinários dos homens. Nota-se, assim, outra estratégia de persuasão sugerida pela tradição dos manuais de retórica, pois falar em primeira pessoa de seus próprios males atrai a compaixão ou o amor dos ouvintes (Retórica a Herênio, I, 8, 2). Dessa forma, o páthos movido pela Pax no leitor é a piedade, tal como Aristóteles o explicava em sua "Retórica" (II. 8. 2): "a piedade consiste numa certa pena causada pela aparição de um mal destruidor e aflitivo, que afeta quem não merece ser prejudicado, que pode prejudicar-nos as nós mesmos, ou a algum dos nossos, principalmente quando esse mal nos ameaça de perto". É o que transparece no exordium, sobretudo no seguinte trecho, ao estabelecer a antítese entre o seu amor e a maldade dos homens:

E, embora eu preferisse somente irar-me contra eles, sou antes compelida a me condoer deles, a ter misericórdia deles. É decerto desumano afastar de si aquele que de alguma forma nos ama; é ingrato hostilizar aquele que merece o bem; é ímpio afligir a progenitora e servidora de todos (Queixa da Paz, 8-11).

Aristóteles (Retórica, I, 12,1) também afirmava que convinha que se caracterizassem os injustiçados em primeiro lugar pelo fato de serem necessitados. A paz é extremamente necessária ao homem, logo, persegui-la se configura como injusto e digno de censura. A intenção seria não somente produzir a piedade para com ela, mas a indignação contra quem persegue e destrói aquela que a tantos beneficia. Aristóteles apresenta a indignação como o contrário da piedade. A primeira muitas vezes nasce da segunda, pois quem se indigna contra os reveses imerecidos tem piedade de quem imerecidamente foi prejudicado (Ibid., II, 9, 2). Logo no início da primeira parte, que trata do homem guerreiro como inferior às feras, a Paz retoma a estratégia de apresentar-se como vítima, a fim de mover o pathos da compaixão dos leitores e acrescenta em seu caráter a capacidade de perdoar: "Se feras me desprezassem desse modo, eu o suportaria mais facilmente, e atribuiria essa ofensa à natureza, que inserira nelas uma índole selvagem" (Queixa da Paz, 31-32).

Após descrever longamente a onipresença dos litígios clericais, inclusive entre os religiosos que deveriam primar pela perfeição dos conselhos evangélicos, a Paz chega ao cúmulo de mostrar-se sem lugar para morar entre os homens, como uma desabrigada e desamparada em razão da onipresença da guerra: 
Mas, pobre de mim! Também aqui verifico que a cidade está totalmente maculada pelas dissidências de seus habitantes, a tal ponto que quase não se pode achar uma única casa na qual exista um lugar para mim por alguns dias. Entretanto, deixo de lado o povo, que, tal como o mar, é arrebatado por seus ardores, e me recolho (Queixa da Paz, 127-130).

Apela, pois, à clemência do coração humano. Como vítima, exige compaixão e procura convencer o homem através de um discurso que move às emoções, sobretudo à comiseração, ao atrair a simpatia expondo os próprios males.

\subsection{Conclusão do capítulo}

Erasmo inovou ao trazer para a declamação uma personificação feminina. A Paz, porém, não é somente caracterizada como uma mulher com as qualidades e defeitos estereotipados nos escritos retóricos erasmianos, que uma visão simplista poderia taxar como preconceituosa, uma vez que reproduz uma valorização negativa da mulher. Se é verdede que Erasmo também reproduz estereótipos masculino com tons não menos severos, é certo de que para ele, o declamador deve estabelecer o caráter da personagem que fala de um modo adequado às expectativas da audiência fictícia e dos leitores reais, a fim de que o discurso cumpra a finalidade persuasiva que é própria do gênero. Sem a caracterização adequada simultaneamente à audiência e à personificação, a declamação não seria persuasiva, pois iria contrariar o princípio retórico da verossimilhança.

A Paz é abstrata, feminina, mais precisamente maternal, mas também é uma espécie de divindade. Deve-se, porém, considerar que sua caracterização como deusa não contemplaria as paixões típicas da mitologia greco-romana, mas uma deusa sem defeitos como o Deus cristão. Esta não é somente anunciada por Cristo, mas é capaz de disputar pela sua própria causa com todos os argumentos possíveis e sugeridos pela antiga tradição retórica. Parafraseando Quintiliano, a Paz então segue aquele ditame de ser uma "mulier divina bona dicendi perita". Esta argumenta baseada em lugares comuns extraídos da natureza (rerum natura), da teologia bíblica e patrística, da economia, da política e de questões diplomáticas pertinentes no século XVI, como uma "seguidora" daquele conselho de Cícero, segundo o qual o orador deve ser proficiente também nas leis, na história e na filosofia para bem argumentar. Além de sábia, a paz é bondosa como uma deusa ao modo cristão. Configurada como uma abstração feminina, a paz se dirige ao clero e aos príncipes com a autoridade de uma deusa, com a estratégia feminina, com a bondade de uma mãe, com argumentos de uma 
sábia, com a piedade de uma teóloga, a fim de persuadir com autoridade suficiente a favor de sua própria causa. Esta seria não a doutrina escolástica da "guerra justa", mas retórica humanista (erasmiana) da "paz justa". 


\section{CONSIDERAÇÕES FINAIS}

A presente dissertação de mestrado teve por objeto de pesquisa o estudo da declamação “Queixa da Paz”, publicada em 1517 por Erasmo de Rotterdam. Como resultado foram apresentados um estudo introdutório sobre o gênero antigo declamação, sua recepção no Renascimento e a primeira tradução direta do latim para o português brasileiro. O texto fonte utilizado foi extraído da edição crítica da obra de Erasmo (Desiderii Erasmi Roterodami Opera Omnia. Amsterdam, 1978).

Ao longo do estudo introdutório discorremos sobre a definição e as principais propriedades da declamação. Delineamos esse gênero discursivo como originário na Grécia, onde se chamava meleté, recebido pelos latinos com o nome de declamação. Distinguimos dois ambientes nos quais era praticada: primeiro, nas escolas de retórica, quando, nos manuais, estava situada entre os últimos exercícios das progymnásmata, caracterizado como um treinamento da performance ou da pronúncia e a simulação do discurso de uma personagem histórica ou mitológica; segundo, em reuniões sociais, ou seja, a prática de discursos fictícios também atribuídos a personagens históricas ou mitológicas, em um ambiente restrito e de nível cultural e econômico elevado, praticado por pessoas que já tinham o hábito da oratória pública, seja judicial, seja deliberativa, a fim de exercitar-se ou mesmo deleitar os convivas. Tal prática assemelhava-se ao hábito da recitatio, na qual os antigos divulgavam em leituras públicas a uma audiência seleta novos escritos em prosa ou em versos.

Verificamos que nos dois ambientes nos quais se praticava a declamação o principal objetivo e desafio do gênero seria a caracterização adequada da personagem fictícia selecionada, onde a representação do êthos discursivo deveria adequar-se à personalidade, à ocasião, ao tema, à audiência, de modo que o discurso fosse maximamente persuasivo e verossímil. Desse modo, a principal figura de linguagem contemplada na declamação seria a prosopopeia.

Quanto às personagens correntemente utilizadas nas antigas declamações, predominavam as masculinas, muito embora também se utilizassem as femininas, conquanto em posições inferiores ou subalternas. Embora não fosse usual a utilização de personificações, 
no sentido de abstrações ou coisas que tomam a voz, nota-se o uso de personagens femininas em posição de protagonista em discursos que ocupavam a integridade da obra nas "Heroides" de Ovídio, muito embora estas não pertencessem ao gênero declamação, mas ao epistolar. Tais dados foram significativos ao constatar esta adição na declamação erasmiana ao apresentar uma personificação feminina como remetente do discurso.

Quanto ao uso de personagens históricas, como é habitual em vários gêneros discursivos, não era preocupação primordial da declamação a exposição histórica exata dos eventos ou das pessoas, mas sim a caracterização adequada e verossímil das personagens através do discurso direto, pois o objetivo não era narrar a história, mas apresentar o discurso adequado de determinado personagem, para determinada audiência, segundo as sensibilidades desta para com os estereótipos já consignados a respeito das prosopopeias selecionadas.

Atestamos que a defesa dos dois lados contrários da causa ou a escolha de apenas um dos lados variou de acordo com a ocasião, mas era costume apresentar os dois lados da causa nas escolas de retórica a fim de exercitar o aluno, o que não era predominante na declamação praticada pelos oradores mais experientes ou em algumas declamações escritas.

Quanto às espécies da declamação, constatamos a existência de escritos em gênero demonstrativo, como elegias e panegíricos, sobretudo em grego; filosófico, praticados nas escolas de retórica; deliberativo, também chamados de suasórias e nos ambientes de discussão pública e na simulação de temas típicos do gênero deliberativo por ocasião de temas históricos, com a finalidade de suadir os cidadãos a optarem, entre outros assuntos, pela paz ou pela guerra, pelo aumento ou diminuição de impostos e outras decisões de interesse público; judicial, também chamados de causae ou controuersiae, por simularem temas e ocasiões próprias dos tribunais.

Ainda sobre a declamação antiga, percebemos que essa, durante a transição de regime político da república para o império tomou paulatinamente o lugar da antiga oratória, tornando-se o gênero apropriado para a prática da emissão dos discursos em forma oral e escrita.

Os atuais corpora das declamações gregas e latinas mais amplos datam justamente do período imperial e foram escritos em latim e grego, dependendo da localização dos seus produtores: assim, Quintiliano, Sêneca, que viveram na parte latina, escreveram sobre a 
declamação ou declamações nessa língua, ao passo que Plutarco, Hélio Aristides, Luciano de Samosata, Libânio de Antioquia e Corício de Gaza, as escreveram em grego. Portanto, embora as origens do termo e das referências à declamação contidas nos manuais de retórica remontem a períodos anteriores, as principais fontes da declamação grega e a latina que chegaram até nós datam da época imperial.

A renovação deste gênero durante o Renascimento está diretamente relacionada à recuperação e reedição, nos séculos XV e XVI, dos corpora antigos que continham declamações ou que tratavam do gênero, como é o caso da reedição do texto completo da “Instituição Oratória” de Quintiliano, em 1416. Tal recuperação partiu do norte da Itália, primeiramente com Salutati e posteriormente com Lourenço Valla. A partir deste, chegou ao norte da Europa, sendo praticada nos dois primeiros decênios do século XVI por Erasmo e More. A partir desses dois humanistas, sobretudo pela influência do roterdamês, foi utilizada por outros contemporâneos, como Vives, Cardano e Agrippa.

O contato com as declamações antigas por Erasmo deu-se basicamente sob quatro formas que classificamos não necessariamente em ordem cronológica: primeiro, como leitor, no período em que ainda era estudante de teologia, ao ter conhecimento das obras que tratavam a respeito, como é as de Quintiliano e Cícero (Chomarat, 1981); segundo, como editor, ao publicar em forma impressa as declamações de Sêneca, o Velho; terceiro, como tradutor, ao transpor do grego para o latim algumas das declamações de Luciano, Libânio e Plutarco; quarto, como escritor, ao publicar onze declamações, tratadas explicitamente por ele já no título das obras, ou classificadas por ele como tal, em epístola a João Botzheim (1523), entre as quais, as mais célebres são o "Elogio da Loucura" e a "Queixa da Paz".

A escrita desta não foi posterior a novembro de 1516 e foi publicada em 1517, quando Erasmo era conselheiro de Carlos V e residia em Lovaina, Bélgica. A obra foi dedicada ao Abade Antônio van Bergen e foi possivelmente redigida a pedido do chanceler João Sauvage. O evento histórico próximo que teria motivado a redação desse discurso em favor da paz foram as guerras da Liga de Cambrai (1508-1510), da Liga Santa (1511-1513) e, por fim, da aliança franco-veneziana (1513-1516), cujos conflitos, dispersos pela Europa, também atingiam os locais de residência ou frequentados pelo roterdamês. 
A característica mais marcante desta declamação de Erasmo é que não apresenta qualquer introdução ou conclusão narrativa, como, por exemplo, costuma ocorrer em algumas das declamações senequianas, mas transcrevia o discurso direto emitido por uma personificação abstrata. Trata-se de uma repetição da prática registrada no "Elogio da Loucura". Não há diálogos no texto, como, aliás, é próprio de uma declamação, entendida geralmente como um monólogo, muito embora o roterdamês classificasse na epístola a João Botzheim (1523) o diálogo "Antibárbaros" como uma declamação, ainda que este apresente mais de uma personagem, cada qual com vários discursos diretos reciprocamente direcionados.

A disposição retórica da obra segue a tradição antiga quanto à estrutura básica: proêmio, narratio, confirmação e epílogo. Mais especificamente, podemos dividir a Queixa da Paz nas seguintes partes, com a numeração correspondente (os números se referem às

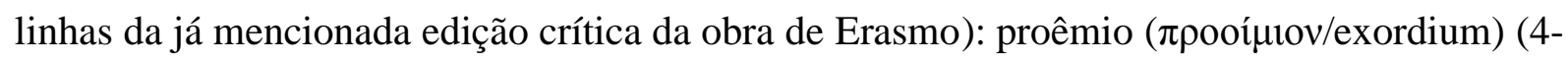

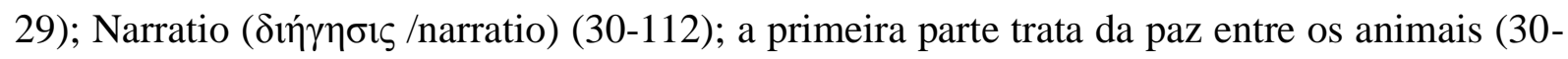
112); a segunda parte descreve a destruição da paz entre os homens (113-202); a confirmação

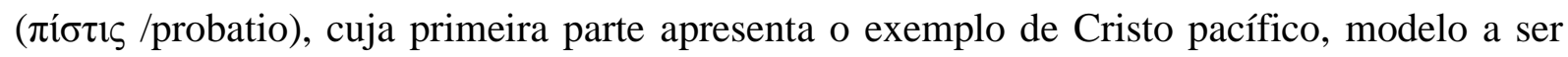
seguido pelos que se dizem cristãos (203-401); a segunda parte apresenta o exemplo dos pagãos (402-435); a terceira parte argumenta como o Estado, as leis, o comércio e o povo são prejudicados pela guerra (436-594); a quarta parte sugere ações para que o príncipe evite a guerra (595-871); e por fim, finaliza-se com o epílogo constituído de vários vocativos

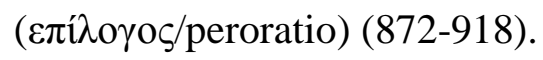

Em conformidade com a tradição antiga das declamações senequianas, notou-se a utilização por Erasmo de sentenças ao longo do discurso, com o objetivo de tornar o texto mais expressivo. Quanto às fontes das sentenças, podemos classificá-las em três grupos: primeiro, as antigas, como Platão (9 e 551), Lívio (1-3), Homero (75), Ovídio (162), Sílio Itálico (210), Cícero (218 e 758), Virgílio (467 e 670), Plauto (764), Plínio (57), Horácio (152) e Aristóteles (391); segundo, as citações de adágios selecionados e remodelados pelo roterdamês em sua própria coletânea de "Adágios" (linhas 18, 22, 62, 77, 91, 155, 505, 553556, 803-804, 866 e 906); terceiro, as de origem bíblica e patrística, especialmente ao tratar de Cristo Pacífico. A versão latina da bíblia citada ao longo da declamação é a Vulgata de Jerônimo. 
Em harmonia com Herding (1974, p. 6), nota-se em algumas partes da obra semelhanças com o gênero espelho do príncipe e a repetição de alguns argumentos irênicos já apresentados por Erasmo em escritos como o "Panegírico a Felipe" e a "Instituição do príncipe cristão". A semelhança averiguada, além da dimensão temática (paz e guerra), também contempla o objetivo suasório de certas partes do discurso da paz, ao dirigir-se ao governante como quem pretende ensinar ou aconselhar baseado em valores éticos típicos dos humanistas, colocando os interesses humanos acima de quaisquer outros princípios. Em Erasmo, mais especificamente, são evocados os princípios cristãos, tratados como perfeitos, muito embora, ao longo do discurso, a prática apontada para os seguidores de Cristo não seja concorde com os valores cristãos elogiados pela Paz. Ao que parece, os próprios argumentos teológicos seguem esta finalidade, ao omitir os argumentos bíblicos e filosóficos favoráveis à guerra justa. $O$ texto sobrepõe a vida humana acima de qualquer outro princípio, seja a honra, seja a proteção dos interesses dinásticos ou estatais. Inclusive os argumentos econômicos são alinhavados segundo esta finalidade de proteção do indivíduo, sobretudo, o indefeso, ao mencionar explicitamente as possíveis ofensas contra a mulher e os camponeses (povo). Convém ainda ressaltar que o humanismo erasmiano é essencialmente cristão, pois fundamenta seus argumentos harmonicamente com as fontes bíblicas e patrísticas, mas é tenazmente contrário às incoerências para com a fé e a ética cristã por parte daqueles que mais especialmente deveriam propagá-la ou praticá-la: o clero e os governantes.

A obra em estudo apresentou ainda traços do gênero deliberativo, o aconselhar (suadere) o auditório (os príncipes e os clérigos) a favor da paz e a evitar a guerra, mas também algumas caraterísticas do gênero demonstrativo ou epidítico, ao elogiar a paz e vituperar contra a guerra. Tal constatação aproxima simultaneamente este escrito aos panegíricos e algumas declamações escritas em grego, pertences ao gênero demonstrativo, e às suasórias senequianas, especialmente as que tratam da paz e da guerra (Suasórias I, II e IV). A mescla dos três gêneros discursivos (demonstrativo, deliberativo e judicial) não era novidade e era mesmo reconhecida na "Instituição Oratória", uma vez que, até no gênero judicial, como se lê na "Retórica a Herênio", era comum o orador vituperar contra os defeitos morais do oponente, ou elogiar as virtudes do seu cliente a fim de angariar a simpatia ou a antipatia do juiz ou do júri conforme o seu interesse. 
Quanto à personificação da paz, além de sua já mencionada semelhança com as prosopoeias femininas das "Heroides", verificamos ainda certa semelhança com as personagens femininas abstratas bíblicas da Sabedoria e da Loucura. Porém, a Paz caracterizada por Erasmo se diferencia destas por apresentar um discurso direto que ocupa a integralidade do livro, e não somente uma parte diminuta. Ademais, a Paz se assemelha à prosopopeiaa da amada presente em "Cântico dos Cânticos" pelo fato de também emitir discursos diretos e ser protagonista do gênero feminino, mas, por outro lado, se diferencia na medida em que a amada dialoga com outras personagens ao longo do livro.

Em relação à Antiguidade, a adição verificada da declamação erasmiana, tanto no "Elogio da Loucura" como na "Queixa da Paz”, é a atribuição da integralidade do discurso direto a uma personificação feminina. Esta é caracterizada como mãe, por nutrir os homens como filhos; como vítima de uma atroz perseguição em toda parte; como sábia que aconselha os príncipes, ao modo do gênero Espelho dos Príncipes, a que conservem a paz e evitem de todos os modos a guerra. O discurso utiliza-se de argumentos filosóficos, como é o caso do lugar comum, segundo o qual se o homem é racional, deve ser tão ou mais pacífico do que os animais, os quais não são dotados de razão e, por consequência, de palavra. Por outro lado, utiliza-se de argumentos teológicos bíblicos, ao apresentar os exemplos de Davi, Salomão e de Cristo Pacífico, como modelos da opção pela paz, própria aos seguidores da religião cristã. A paz utiliza-se ainda de argumentos de ordem política, social e econômica: primeiro, no que tange à política, é mantenedora da estabilidade do reino e da sucessão hereditária monárquica, assim como do livre trânsito entre as fronteiras dos países europeus; segundo, no que diz respeito aos aspectos sociais, aponta a desestruturação da vida da cidade por causa da manutenção de um corpo de mercenários habituados à violência junto a uma população indefesa; terceiro, com argumentos de dimensão econômica, indica os diminutos gastos da resolução pacífica das controvérsias interestatais em comparação com o modo bélico e os empecilhos naturais ao comércio, em situações de guerra ou sítio.

A paz mostra-se, assim, como portadora do ideal da tradição retórica antiga recebida e imitada no Renascimento ao caracterizar-se como aquilo a que poderíamos chamar mulier bona dicendi perita. Ela utiliza-se dos diversos recursos retóricos proporcionados pela declamação, especialmente a simulação de um discurso fictício em formato de prosopopeia, para mover seus leitores a sentimentos e atitudes pacíficas. Utiliza-se da comiseratio ao 
colocar-se como vítima e evoca a injusta reação dos homens para com seus inumeráveis e incontestes benefícios. O homem guerreiro contraria a razão, mostra-se sem compaixão para com seus semelhantes e contradiz a própria essência do cristianismo que apresenta o Príncipe da Paz como ideal a ser seguido e imitado. No caso dos detentores de influência social, como clérigos e eruditos, a paz estimula que propaguem o ideal da paz. Por fim, ao dirigir-se aos governantes, propõe a si mesma como o esteio mestre de uma política próspera e humana. 


\section{NOTA PRÉVIA AO TEXTO LATINO E À TRADUÇÃO PORTUGUESA COMENTADA}

Quinhentos anos depois da publicação da "Queixa da Paz" em 1517, suas palavras ecoam em pleno século XXI com surpreendente atualidade. Esta declamação não somente se apresenta como um primor da recepção e da imitação dos antigos clássicos. Nela, a personificação da paz lamenta contra a guerra e argumenta a favor de si mesma com aquele estilo elegante, irônico e incisivo de Erasmo. Suas argumentações contemplam praticamente todas as dimensões de relacionamento humano: no interior do coração humano, na família, nas relações interpessoais e entre os estados. Se de um lado muitos pensadores já discorreram sobre a paz, que tal a ouvirmos falar de si mesma? É exatamente este o grande presente que Erasmo proporcionou aos seus leitores naquele início do século XVI e cuja primeira tradução para o português brasileiro o leitor tem em mãos.

Esta tradução está precedida da carta-proêmio de Erasmo a Felipe, que foi publicada juntamente com a "Queixa da Paz". As notas parcas em extensão e quantidade têm o objetivo de esclarecer algumas variantes entre as edições, expressões que remetem aos antigos, dificuldades de tradução e informações pertinentes sobre lugares, adágios e personagens citados no texto, não evidentes para muitos leitores modernos. Algumas destas referências foram baseadas nas notas da edição crítica propostas por Herding (1977), nas notas das traduções publicadas por Margolin (1992) e Pinto (1999) e no estudo de Tunberg (1996). Os comentários em nota estão redigidos de forma que sejam explicativos para pessoas não especializadas nos estudos clássicos ou nas referências históricas ou eclesiásticas utilizadas por Erasmo em uma possível publicação desta tradução. O texto latino e a numeração entre colchetes das linhas contidas seguem a edição crítica da presente na Desiderii Erasmi Opera Omnia (IV-2, 1977, p. 59-101). Utilizamo-nos do dicionário de Gaffiot como material de consulta, além de outras traduções da obra para outras línguas, conforme listamos na bibliografia. Esta tradução não visa simplificar o texto de Erasmo a fim de adaptá-lo ao mercado livresco. O público-alvo de nossa tradução assemelha-se àquele do roterdamês, ou seja, o leitor erudito em geral, e ao acadêmico, em particular. Nossa tradução visa ser o mais fiel possível à declamação. Essa fidelidade ao gênero exige então o cuidado em relação ao nível de linguagem utilizado a fim de manter não somente a extensão dos parágrafos, os 
quiasmos e as anáforas utilizadas, mas também as imagens retiradas da cultura clássica e bíblica. 


\section{Texto latino da edição crítica}

[1] Clarissimo praesuli traiectensi Philippo, Erasmo Roteramus S. D.

[3] Gratularer tibi Philippe praesul, non minus vitae ornamentis quam summorum ducum imaginibus clarassime, quod tanti muneris honore sis auctus, ni compertum [5] haberem, quam invitus susceperis quamque gravate optimi maximique principis Caroli autoritate fueris adactus, cuius alioqui charitati nihil non eras daturus.

[7] Atque, haec ipsa res spem nobis certissimam facit fore, ut cum laude perfungaris suscepto, quandoquidem Plato vir exquisitissimi planeque divini iudicii non alios existimat ad rempublicam gerendam idoneos, quam eos qui [10] huc nolentes pertrahuntur.

[10] Auget autem nostram de te fiduciam, quoties in mentem venit, et cui tu succedas fratri et quo patre sitis ambo profecti.

[11] Nam David vir eruditus iuxta ac prudens permultis annis sic locum istum tenuit, ut suis ornamentis, sábio pelos muitos anos, manteve essa posição

\footnotetext{
${ }^{43}$ Felipe de Borgonha é um filho bastardo de Felipe, o Bom (1396-1467).

${ }^{44}$ Platão. República. 7.520D; Erasmo. Institutio Principis Christiani. ASD IV-1, p. 152, I, 514ss.

${ }^{45}$ Como o destinatário, um filho bastardo de Felipe o Bom, duque da Borgonha, que foi bispo de Utrecht de 1455 até sua morte em 1496. Segundo a edição crítica, em algumas edições, encontramos a seguinte variante:

Nam David, germanus tuus, vir eruditus... Tal lectio foi considerada menos original no aparato crítico.
}

\section{Tradução}

Erasmo de Roterdam a Felipe, Bispo de Utrecht, saudações. ${ }^{43}$

menos pelo esplendor da vossa vida do que pela grande e principesca linhagem, eu me congratularia contigo o acréscimo do seu novo e mais honroso cargo, se eu não soubesse com que relutância o assumiste, e com que dificuldade foste impelido (a isso) pela autoridade do melhor e maior dos príncipes, Carlos, pelo qual sentes tal afeição que concordarias com qualquer coisa.

É justamente isso que nos deu a segura esperança de que tu desempenhes teu encargo com louvor: Platão, ${ }^{44}$ varão de excelente e preciso juízo, quase divino, julgou que ninguém é mais apto a governar um corpo político do que aqueles que são chamados a atuar contra a sua vontade.

Ora, aumenta nossa confiança em ti toda vez que temos em mente as qualidades do irmão que sucedeste e o pai do qual ambos vós procedestes.

Pois, Davi, ${ }^{45}$ varão igualmente erudito e istum tenuit, ut suis ornamentis, sábio pelos muitos anos, manteve essa posição 
plurimum splendoris ac dignitatis addiderit ipsi muneri per se licet amplissimo, multis modis magnus ac suspiciendus, sed in hoc praecipue [15] salutaris reipublicae, quod nihil ducebat antiquius sibi pace publica, hac quoque in parte patrem Philippum Burguindiae ducem referens virum nulla non re maximum, sed tamen pacis artibus cum primis insigem et aeternae hominum memoriae commendatum.

[18] Qui tibi hoc etiam impesius erit exprimendus non tantum ut filius patri, sed ut Philippus Philippo respondeas.

[20] Intelligit iam dudum tua prudentia, quid abs te populus universus expectet. [21] Triplex onus humeris sustines: patris exemplum ac fratris, tum horum temporum fata (quid enim aliud dicam?) nescio quomodo ad bellum pertrahentia. [23] Vidimus ipsi nuper, ut quidam amicis quam hostibus graviores nihil intentatum reliquerint, ne bellorum aliquando finis esset, rursus ut vix expresserint alii, qui [25] reipublicae principique ex animo bene volunt, ut pacem cum Francis semper optanda, sociedade e ao príncipe, que deve perseguir a paz de tal modo que acrescentou, por seus próprios méritos, a dignidade e o esplendor ao próprio ofício, por mais prestigioso que ele fosse em si mesmo, que a si, como grande e admirável homem, convinha com grande e largueza e variedade, mais salutar à República sobretudo por isto: pelo fato de que pensou nada ser mais importante do que a paz pública, tal como evocou o teu pai, Felipe, duque da Borgonha, um grande homem em todas as matérias mas insigne sobretudo pelas artes da paz e confiado à eterna memória dos homens. ${ }^{46}$

Deverás tomá-lo como modelo, de modo que são sejas [para ele] somente o que um filho é para o pai, mas que respondas a Felipe como [outro] Felipe!

Entende há muito tempo a tua prudência o que todo o povo espera de ti. Carregas um triplo peso nos ombros: o exemplo do teu pai, do teu irmão e os destinos destes tempos (o que mais poderia eu dizer?) não sei como atraídos para a guerra. Nós mesmos vimos ultimamente ${ }^{47}$ como alguns nada deixaram de tentar, embora sendo mais severos aos seus amigos do que aos seus inimigos, a fim de assegurar que a guerra jamais tenha fim; a dificuldade encontrada pelos outros, que sinceramente desejam o bem para a

\footnotetext{
${ }^{46} \mathrm{O}$ reinado de Felipe de Borgonha foi pacífico em certo grau, mas acima de tudo, por obter uma reconciliação com a França ao final da guerra dos cem anos.

${ }^{47}$ A composição da Queixa da Paz está relacionada à política de aproximação com a França e de paz universal, promovida por Chièvres e João Sauvage, que emanaram os tratados de Noyon (augusto de 1516) e Cambrai (março de 1517).
} 
hisce vero temporibus etiam necessariam amplecteremur.

[26] Cuius sane rei indignitas movit animum meum, ut tum Pacis undique profligatae Querimoniam scriberem, quo nimirum hac ratione iustissimum animi mei dolorem vel ulciscerer vel lenirem.

[29] Libellum ad te ceu primitiolas novo episcopo debitas [30] mitto, quo diligentius tueatur tua celsitudo pacem utcunque partam, si non patiar eam obliuisci quanto negocio nobis costiterit. Bene Vale.

\section{[1] QUERELA PACIS UNDIQUE Queixa da paz perseguida e rejeitada em toda GENTIUM EIECTAE parte pelas nações}

para com a França, a qual sempre deve ser por nós abraçada, especialmente nesses dias.

A indignação com essas coisas moveu completamente o meu espírito a fim de escrever a queixa da paz perseguida em toda parte, de modo que, por este meio, poderia vingar ou pacificar a justíssima dor do meu espírito.

Envio então esta pequena obra, como uma espécie de primícia devida ao nosso bispo, a fim de que Vossa Alteza possa ser mais diligente para preservar a paz, se não permito esquecê-la quanto trabalho nos custou.

Passe bem.

\section{PROFLIGATAEQUE}

\section{AVTORE DESIDERIO ERASMO De autoria de Desidério Erasmo de Rotterdam ROTERODAMO}

Se, mesmo que não merecendo, ${ }^{48}$ os

[4] Si me, licet immerentem, suo mortais ainda assim de tal modo me tamen commodo sic aversarentur, hostilizassem, perseguissem e rejeitassem tendo eiicerent profligarentque [5] mortales, em vista sua própria vantagem, eu deploraria meam modo iniuriam et illorum apenas a minha injúria e a iniquidade deles. Mas, iniquitatem deplorarem. Nunc cum me uma vez que eles, tendo me rejeitado, impedem a profligatam protinus fontem omnis si mesmos de saciar-se na fonte de toda humanae felicitatis ipsi a semet arceant felicidade humana e se precipitam no mar de

\footnotetext{
${ }^{48}$ Cf. Terêncio. Hec. 5, 1, 14: "inscitum afferre iniuriam tibi immerenti”.
} 
omniumque calamitatum pelagus sibi accersant, magis illorum mihi deflenda est infelicitas quam mea iniuria, et quibus irasci tantum maluissem, horum dolere vicem, hos commiserari compellor. Nam utcumque amantem [10] ab se propellere inhumanum est, bene merentem aversari ingratum, parentem ac servatricem omnium affligere impium. Caeterum tot egregias commoditates, quas mecum adfero, sibimetipsis invidere proque his ultro tam tetram malorum omnium lernam accersere, an non hoc extremae cuiusdam dementiae videtur? Sceleratis irasci par est: at sic furiis actos quid aliud quam deflere possumus? [15] Qui non alio sane nomine magis deflendi sunt, quam quod ipsi sese non deflent, nec alio magis infelices, quam quod infelicitatem suam non sentiunt, quando nonnullus gradus est ad sanitatem morbi sui magnitudinem agnoscere. Etenim si ego sum Pax illa divorum simul et hominum voce laudata fons, parens, altrix, ampliatrix, tutatrix rerum bonarum omnium, quas vel caelum habet ve (sic) [20] terra, si sine me nihil usquam florens, nihil tutum, nihil purum aut sanctum, nihil aut iucundum hominibus, aut gratum superis, si contra haec omnia bellum semel omnium malorum quicquid usquam est in rerum natura oceanus todas as calamidades, então devo lamentar mais a infelicidade deles do que a injúria contra mim. E, embora eu preferisse somente irar-me contra eles, sou antes compelida a me condoer deles, a ter misericórdia deles. É certamente desumano afastar de si o que de algum modo nos ama; é ingrato hostilizar o que merece o bem; é ímpio afligir a progenitora e servidora de todos. Ademais, acaso não parece ser de uma demência extrema isso de recusar para si mesmos as vantagens tão grandes que comigo trago, e, no lugar delas, invocar a tão terrível Lerna de todos males? É justo irar-se contra os criminosos; mas que mais podemos fazer senão lamentar aqueles que agiram assim por causa das Fúrias? Estes certamente devem ser lamentados não por outro motivo senão justamente porque não lamentam a si mesmos, nem, por outro lado, há homens mais infelizes do que aqueles que não percebem sua própria infelicidade, uma vez que reconhecer o tamanho da própria doença é um passo para a cura. Se eu, pois, sou aquela Paz, louvada a uma só voz pelos deuses e pelos homens, fonte, progenitora, aleitadora, fomentadora, tutora de todas as coisas boas que existem, quer no céu, quer na terra; se, sem mim, não há nada que floresça em parte alguma; sem mim nada é seguro, nada é puro ou santo, e nada é alegre para os homens ou agradável aos céus; se, em contrapartida a tudo isto, uma única guerra, onde quer que esteja na natureza das coisas, é uma espécie de oceano de todos os males ao mesmo 
quidam, si huius vitio subito marcescunt florentia, dilabuntur aucta, labascunt fulta, pereunt bene condita, amarescunt dulcia, denique si res est adeo non sancta, ut omnis [25] pietatis ac religionis sit maxime praesentanea pestis; si nihil hoc uno infelicius hominibus, nihil invisius superis, quaeso per deum immortalem, quis credat istos homines esse, quis credat ullam sanae mentis micam inesse, qui me talem, tantis impendiis, tantis studiis, tanto molimine, tot technis, tot curis, tot periculis student eiicere tantumque malorum velint tam chare emere?

[30] Si me ad istum modum spernerent ferae, levius ferrem, et in me admissam contumeliam naturae imputarem, quae ingenium immite insevisset: si mutis pecudibus essem invisa, condonarem inscitiae, propterea quod his ea vis animi negata sit, quae sola dotes meas queat perspicere. At o rem indignam ac plus quam prodigiosam, unum animal aedidit natura ratione praeditum ac divinae [35] mentis capax, unum benevolentiae concordiaeque genuit et tamen apud quantumlibet efferas feras, apud quantumvis brutas pecudes mihi citius locus sit quam apud homines. Iam tot orbium coelestium, licet tempo; se por influência dela, as coisas que estavam florescendo subitamente murcham, as grandes se dissolvem, os fundamentos ruem, as bem construídas perecem, as doces amargam; em suma, se é algo a tal ponto sacrílego, que é como a peste venenosa de toda a piedade e religião; se não há nada mais infeliz para os homens do que ela; se nada é mais odioso para os céus, por favor, pelo Deus imortal, quem acreditará que tais homens existam; quem acreditará que há uma única migalha de bom senso em seres que, com tantos esforços, tantos trabalhos, com tanto peso, com tantas técnicas, com tantos cuidados, tantos perigos, empenhem-se em me lançar fora, a mim, que sou assim, e prefiram pagar tão caro por uma quantidade tão grande de males?

Se feras me desprezassem desse modo, eu o suportaria mais facilmente, e atribuiria essa ofensa à natureza, que inserira nelas uma índole selvagem. Se eu fosse odiada pelo gado mudo, eu o perdoaria por sua ignorância, porque lhe foi negada a faculdade do entendimento, que é a única capaz de perceber os meus dons. Mas, ó coisa indigna e mais que monstruosa, a natureza só produziu um animal dotado de razão e capaz da mente divina, só gerou um ser capaz de benevolência e de concórdia, e, no entanto, é mais fácil haver um lugar para mim junto às feras, por mais ferozes que sejam, e às bestas, por mais brutas que sejam, do que junto aos homens. Já dentre os corpos celestes, que são tantos: embora seus movimentos não sejam 
nec motus sit idem, nec vis eadem, tamen iis tot iam seculis constant vigentque foedera. Elementorum pugnantes inter se vires aequabili libramine pacem aeternam tuentur et in tanta [40] discordia consensu commercioque mutuo concordiam alunt. In animantium corporibus quam fidus membrorum inter ipsa consensus, quam parata defensio mutua. Quid tam dissimile quam corpus et anima? Et tamen quam arcta necessitudine connexuerit haec duo natura, nimirum declarat ipsa divulsio. Proinde ut vita nihil aliud est quam corporis et animae societas, ita sanitas omnium [45] corporis qualitatum concentus est. Animantia rationis expertia in suo quaeque genere civiliter concorditerque degunt. Armentatim vivunt elephanti, gregatim pascuntur sues et oves, turmatim volant grues et graculi, habent sua comitia ciconiae, pietatis etiam magistrae, mutuis officiis sese tuentur delphini. Nota est formicarum et apum inter ipsas concors politia. Sed quid de his loqui pergo, [50] quae tametsi ratione vacant, sensu non vacant?

[51] In arboribus, in herbis amicitiam possis agnoscere. Steriles sunt quaedam, nisi marem adiungas; vitis ulmum amplectitur, vitem amat persica. iguais, nem sua energia seja a mesma, contudo desde há muitos séculos existem e vigoram entre eles pactos. As forças dos elementos que lutam entre si mantêm a paz eterna através de um equilíbrio constante, e, em meio a tão grande discórdia, fomentam a concórdia por meio do consenso e do trato recíproco. Nos corpos dos seres animados, como é sólido o consenso dos membros entre si e quão preparado para a defesa mútua. Que existe de mais diferente do que o corpo e a alma? E, contudo, a própria separação evidencia com quão estreito laço a natureza uniu essas duas coisas. De forma que, assim como a vida nada mais é que a associação do corpo e da alma, assim também a saúde do corpo é a harmonia de todas as suas propriedades. Os animais desprovidos de razão, qualquer que seja a espécie, convivem em harmonia e em concórdia. Os elefantes vivem em manada, porcos e ovelhas são apascentados em rebanhos, os grous e os estorninhos voam em bando, as cegonhas, mestras de fidelidade, têm seus grupos, os golfinhos ajudam-se uns aos outros com cuidados mútuos, e notório é o regime cordial das formigas e das abelhas entre si. Mas para que continuo a falar dessas criaturas, que, embora desprovidas de razão, não são desprovidas de sentimento?

Entre as árvores e as plantas, poderias reconhecer a amizade. Algumas delas são estéreis, a menos que lhes acrescentes o macho; o olmeiro é abraçado pela videira, o pessegueiro 
Usque adeo quae nihil sentiunt, tamen pacis beneficium sentire videntur. Sed haec rursum ut sentiendi vim non habent, ita quod vitam habeant, iis quae sentiunt finitima [55] sunt. Quid aeque brutum atque saxorum genus? Dicas tamen his quoque pacis et concordiae sensum inesse. Ita Magnes ferrum ad sese trahit, attractum tenet. Quid quod inter immanissimas etiam feras conuenit? Leonum inter ipsos feritas non dimicat. Aper in aprum non vibrat dentem fulmineum. Lynci cum lynce pax est. Draco non saevit in draconem. Luporum concordiam etiam proverbia nobilitarunt. [60] Addam, quod magis etiam mirum videatur, impii spiritus, per quos caelitum atque hominum concordia primum dirupta est et hodie rumpitur, tamen inter se foedus habent suamque illam qualemcumque tyrannidem consensu tuentur.

[64] Solos homines, quos omnium maxime decebat unanimitas quibusque cum [65] primis opus est ea, neque natura tam aliis in rebus potens et efficax conciliat, nec institutio coniungit, nec tot ex consensu profecturae commoditates conglutinant, nec tantorum denique malorum sensus et experientia in mutuum ama a videira. Até mesmo aqueles que nada sentem, parecem, no entanto, sentir o benefício da paz. Mais ainda: se esses seres não têm a capacidade de sentir, são, na medida em que têm vida, próximos daqueles que sentem. O que há de tão bruto quanto à raça das pedras? Dizes, contudo, que também nestas está contido o senso da paz e da concórdia. Assim, o imã atrai o ferro para si e, tendo-o atraído, o retém. O que é isso que congrega até as feras mais selvagens entre si? A ferocidade dos leões entre eles não aparece. ${ }^{49}$ Um javali não vibra seu dente afiado contra outro javali; há paz de lince com lince; a serpente não se enfurece com outra serpente; e até os provérbios elogiaram a concórdia que existe entre lobos. Acrescentarei ainda algo que parece mais espantoso: os espíritos ímpios (por meio dos quais a concórdia entre os céus e os homens se rompeu, no começo, e ainda hoje se rompe), têm, contudo, um pacto entre si e mantém aquela sua tirania através do consenso.

De todos os seres, são os homens aqueles a quem mais convinha a união e a que, de longe, ela é mais necessária, porém, de todos, são os únicos que nem a natureza, tão potente e eficaz em outras coisas, concilia, nem a instrução une, nem associam as facilidades advindas de um acordo a ser firmado; nem, enfim, a percepção e a experiência de tão grandes males reconduz ao

\footnotetext{
${ }^{49}$ Margolin (1992, p. 914) identifica uma recepção de Plínio (História natural. VII, 5).
} 
amorem redigit. Figura communis amor mútuo. A aparência é comum a todos, a omnium, vox eadem; et cum caetera voz é a mesma, e, embora as demais espécies dos animantium genera corporum formis animais se diferenciem umas das outras potissimum inter se differant, uni homini sobretudo pelas formas dos corpos, só ao homem indita vis [70] rationis, quae ita sit illis foi infundida a razão, que, assim como é comum inter ipsos communis, ut cum nullo sit entre eles mesmos, não é comum entre eles e os reliquorum animantium communis, uni demais animais. ${ }^{50}$ Só a este ser animado foi huic animanti sermo datus, praecipuus concedida a fala, que é o principal conciliador necessitudinum conciliator. Insita sunt communiter disciplinarum ac virtutum semina, ingenium mite placidumque et ad mutuam benevolentiam propensum, ut per se iuvet amari et iucundum sit de aliis benemereri, nisi quis pravis cupiditatibus [75] ceu Circes pharmacis corruptus ex homine degenerarit in belluam. Hinc est, videlicet, quod vulgus, quicquid ad mutuam benevolentiam pertinet humanum appellat. Addidit lacrymas, exorabilis ingenii documentum, quo si quid forte inciderit offensae et amicitiae serenitatem nubecula aliqua obfuscarit, facile redeant in gratiam. dos laços sociais: foram-lhe inseridas as sementes dos saberes e das virtudes, de um temperamento doce, plácido e propenso a uma mútua benevolência, de tal forma que lhe agrada ser amado pelo que é, e sente-se alegre em fazer gratuitamente o bem a quem o merece, a não ser que alguém, corrompido por perversos desejos, como que pelos alucinógenos de Circe, ${ }^{51}$ se degenere de homem em fera. ${ }^{52} \mathrm{E}$ por isso que, não sem razão, o vulgo chama humano a tudo aquilo que diz respeito à benevolência mútua. ${ }^{53}$ Acrescentou-lhe as lágrimas, comprovação de um espírito sensível a pedidos de desculpas, para que facilmente se façam as pazes, caso ocorra talvez um incidente ofensivo ou alguma nuvenzinha ofusque a serenidade da amizade.

En quot rationibus natura Eis com quão grande número de

${ }^{50}$ Cf. Quintiliano, Instituição Oratória, II, 16, 17-18. Segundo Margolin (1992, p. 914), "tema banal da superioridade do homem, dotado de linguagem e de razão".

${ }^{51}$ Herding (1978, p. 65, nota 75) percebe a recepção de Homero (Odisseia, X, 235ss): "Circes pharmacis”.

${ }^{52}$ Alusão ao trecho da Odisseia (X, 310), segundo o qual, a deusa feiticeira Circe, filha do deus Hélio com a feiticeira Hécate, especialista em venenos, acolhe primeiramente, depois furiosamente Ulisses e seus companheiros. Segundo Margolin (1992, p. 915), "trata-se de um tema clássico da degenerescência moral ou física dos homens, metamorfoseados em bestas ferozes para a liberação dos seus instintos brutais".

${ }^{53}$ Noção capital entre os humanistas: Erasmo não pensa ser a humanitas um dom natural do homem, pois ele se torna humano. A razão bem formada deve fazer redescobrir a verdadeira natureza do homem, que lhe permite comandar e superar sua natureza instintiva. 
concordiam docuit! Nec his tamen [80] contenta pacis lenociniis amicitiam homini non solam iucundam esse voluit, verum etiam necessariam. Eoque tum corporum tum animorum dotes ita partita est, ut nemo sit omnium tam instructus, quin infimorum etiam officio nonnumquam adiuvetur, nec eadem attribuit omnibus nec paria, ut haec inaequalitas mutuis amicitiis aequaretur. Aliis in regionibus alia proveniunt, quo vel usus [85] ipse mutua doceret commercia.

[86] Caeteris animantibus sua tribuit arma praesidiaque, quibus sese tuerentur; unum hominem produxit inermem, atque imbecillum nec prorsus aliter tutum quam foedere mutuaque necessitudine. Civitates repperit necessitas et ipsarum inter se societatem docuit necessitas, quo ferarum ac praedonum vim cunctis [90] viribus propellerent. Adeo nihil est in rebus humanis, quod ipsum sibi sufficiat. In ipsis statim vitae primordiis perisset hominum genus, nisi conditum propagasset coniugalis concordia; nec enim nasceretur homo et mox natus argumentos a natureza nos ensinou a concórdia! Não satisfeita, contudo, com esses encantos que resultam da paz, quis que a amizade fosse não somente agradável, mas também necessária para o homem. Por essa razão, repartiu de tal forma os dotes, tanto os dos corpos quanto os dos espíritos, que não há ninguém que seja tão dotado de todos eles que jamais necessite ser socorrido pelo auxílio dos subalternos; tampouco atribuiu a todos características idênticas e iguais, a fim de que essa desigualdade fosse equilibrada através de amizades mútuas. As diferentes regiões produzem coisas diferentes, de modo que a própria utilidade ensinasse os mútuos comércios.

Aos outros animais a natureza concedeu armas e recursos a fím de se defenderem; só o homem ela produziu indefeso e fraco, dependente para sua segurança inteiramente de aliança mútua e dos laços de solidariedade. ${ }^{54} \mathrm{~A}$ necessidade inventou as cidades, e a necessidade ensinou a sociedade entre elas, a fim de, unindo forças, repelir o ataque das feras e dos ladrões. Mais ainda: não há nada nas coisas humanas que baste a si mesma. O gênero humano teria perecido logo nos primeiros estágios da vida, se, uma vez criado, a concórdia conjugal não o tivesse propagado: pois o homem nem nasceria, ou morreria logo ao nascer e expiraria no limiar mesmo da vida, se a mão amiga das parteiras e

\footnotetext{
${ }^{54}$ É o mito de Epimeteu, que ao criar os animais com seus respectivos atributos, concedeu ao homem o fogo dos deuses, ensinando-lhe também como trabalhar com ele (Cf. Platão. Protágoras. 320C-322C).
} 
interiret atque in ipso vitae limine vitam amitteret, nisi obstetricum amica manus, nisi nutricum amica pietas, succurreret infantulo. Atque in hunc usum vehementissimos [95] illos pietatis igniculos insevit, ut parentes etiam illud ament, quod nondum viderunt. Adiecit mutuam liberorum erga parentes pietatem, ut illorum imbecillitas horum praesidiis vicissim sublevaretur, fieretque illa cunctis quidem ex aequo plausibilis, sed Graecis aptissime dicta $\dot{\alpha} \mu \tau \imath \pi \varepsilon \lambda \alpha ́ \rho \gamma \omega \sigma ı$. $\quad$ Accedunt huc cognationum et affinitatum vincula, accedit in nonnullis ingeniorum, studiorum [100] formaeque similitudo, certissima benevolentiae conciliatrix, in multis arcanus quidam animorum sensus ac mirus ad mutuum amorem stimulus, quem veteres admirati numini uma divindade. adscribebant.

[103] Tot argumentis natura docuit pacem concordiamque, tot illecebris ad eam invitat, tot laqueis trahit, tot rebus compellit. Et post haec quaenam ista tam ad [105] nocendum efficax Erinnys his omnibus disruptis, disiectis, discussis, insatiabilem pugnandi furiam insevit humanis pectoribus? Nisi se a piedade amiga das amas de leite não socorresse o bebezinho. Mas, tendo em vista sua utilidade, a natureza inseriu nos homens fortíssimos estímulos de piedade, a fim de que os pais amem até aquilo que ainda nem sequer viram. Acrescentou a piedade mútua dos filhos para com os pais, para que a fraqueza destes seja, por sua vez, amparada pelos cuidados daqueles e a que se dê aquele sentimento, certamente válido para todos, mas a que os gregos chamaram mais

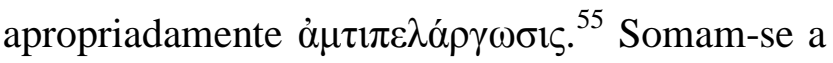
estes os vículos das consanguinidades e das afinidades. Acrescente-se em alguns a semelhança de temperamento, de feições e de interesses, a qual é a mais certa conciliadora da benevolência, havendo também em muitos homens uma espécie de sentido misterioso das almas e uma maravilhosa tendência para o amor mútuo, que os antigos, admirados, atribuíam a

Com tão grande número de argumentos a natureza nos ensinou a paz e a concórdia; a ela nos convida com tão grande número de seduções; para ela nos arrasta e compele com tantos laços e razões! E, no entanto, que Erínia foi essa, tão eficaz em prejudicar, que, tendo todas aquelas coisas sido destruídas, destroçadas e arrasadas, infundiu nos corações humanos a

\footnotetext{
${ }^{55} \mathrm{O}$ termo deriva de $\pi \varepsilon \lambda \alpha \rho \gamma o ́$ s e se refere à piedade da cegonha conforme a literatura grega. Margolin (1992, p. 916) sugere a tradução como "reconhecimento filial" ou de "piedade filial" com a ideia de uma piedade que "retorna".
} 
primum admirationem, deinde sensum etiam mali adimeret assuetudo, quis crederet humana mente praeditos istos, qui sic iugibus dissidiis, litibus, bellis inter sese certant, rixantur, tumultuantur? Postremo rapinis, sanguine, cladibus, ruinis, sacra profanaque [110] miscent omnia: nec ulla tam sancta foedera, quae illos in mutuam perniciem debacchantes queant dirimere. Ut nihil etiam accesserit, satis erat commune hominis vocabulum, ut inter homines conveniret.

[113] Sed esto: nihil apud homines profecerit natura, quae plurimum valet ut in beluis. Itane nihil et apud Christianos valuit Christus? Parum efficax sit doctrina [115] naturae, quae maximam vim habet in his quoque quae sensu vacant. Caeterum cum hac multo praestantior sit doctrina Christi, cur ea se profitentibus non persuadet id quod unum omnium maxime suadet, nempe pacem mutuamque benevolentiam? Aut saltem hanc tam impiam efferamque belligerandi insaniam dedocet? Cum hominis vocabulum audio, mox accurro velut ad animal mihi [120] proprie natum confidens fore, ut illic liceat acquiescere ; cum Christianorum audio titulum magis etiam advolo apud hos certe regnaturam insaciável fúria de fazer a guerra? Se o costume não tivesse feito desaparecer primeiro o espanto, depois até a emoção diante do mal, quem acreditaria que são providos de razão humana esses que lutam entre si, se confrontam e se combatem com constantes dissensões, litígios e guerras? Finalmente, com pilhagens, sangue, assassinatos e destruições, misturam todas as coisas sagradas e profanas; nem há alianças, por mais sagradas, que eles não sejam capazes de romper, inebriados para sua mútua destruição. Para que nada disso uma vez mais ocorresse, seria suficiente a simples palavra "homem", para que os homens se unissem.

Mas que seja. A natureza, que tem tão grande poder entre os animais, nada pode junto aos homens; mas será que Cristo também não pôde nada entre os cristãos? Que seja pouco eficaz a doutrina da natureza, a qual tem máxima força até para os seres privados de sentidos: mas, sendo a doutrina de Cristo muito superior, por que esta não é capaz de persuadir os que a professam aquilo que ela ensina sobre todas as coisas, a saber, a paz e a mútua benevolência? Ou, pelo menos, não os dissuade de tão ímpia e selvagem insânia de guerrear? Quando ouço a palavra homem, logo acudo como a um animal nascido de mim, confiante de que nele encontrarei o lugar do meu repouso; quando ouço a designação de cristãos, voo mais ainda, na esperança de que entre eles certamente hei de reinar. Entretanto, aqui também me envergonha e 
etiam me sperans. Sed hic quoque pudet ac piget dicere: fora, basilicae, curiae, templa sic undique litibus perstrepunt, ut nusquam apud ethnicos aeque; adeo ut cum bona pars humanae calamitatis sit advocatorum turba, tamen haec etiam ad litigantium [125] undas paucitas sit ac solitudo. Civitatem adspicio, spes illico oboritur inter hos saltem convenire, quos eadem cingunt moenia, eaedem moderantur leges, et velut una vectos navi commune continet periculum. Sed, o me miseram, quae hic quoque dissidiis omnia vitiata comperio adeo, ut vix domum ullam reperire liceat, in qua mihi sit vel dies aliquot locus. Sed plebem omitto, quae maris ritu [130] suis aestibus rapitur.

[131] In principum aulas, velut in portum quemdam me recipio. Erit, inquam, certe apud hos locus paci; plus hi sapiunt quam vulgus, ut qui sint plebis animus atque oculus populi, tum eius vices gerunt, qui doctor est et princeps concordiae, a quo quidem cum omnibus, tum his praecipue sum commendata. Et [135] omnia bene pollicentur. Video blandas consalutationes, amicos angustia dizer: os fóruns, as basílicas, os tribunais e as igrejas ressoam por todos os lados com tal violência como nunca houve igual entre os gentios. A tal ponto que, embora boa parte da calamidade humana esteja na turba dos advogados, esta, no entanto, em relação às ondas dos litigantes, é um nada, um deserto. Olho para a cidade e imediatamente renasce minha esperança de que exista união ao menos entre aqueles que as mesmas muralhas circundam e são regidos pelas mesmas leis e que como que navegam num mesmo navio, unidas por um perigo em comum. Mas, pobre de mim! Também aqui verifico que a cidade está totalmente maculada pelas dissidências de seus habitantes, a tal ponto que quase não se pode achar uma única casa na qual exista um lugar para mim por alguns dias. Entretanto, deixo de lado o povo, que, tal como o mar, é arrebatado por sua própria agitação. ${ }^{56}$

Voltei-me às cortes dos príncipes como a uma espécie de porto. Digo que certamente existirá junto a estes um lugar para a paz, pois eles sabem mais que o vulgo, de forma que são a alma e os olhos do povo. Eles fazem, pois, às vezes deste que é o doutor e o príncipe da concórdia, não só por este fui recomendada, mas também por eles. E tudo isso eles prometem. Vejo saudações suaves, abraços amigáveis, alegres banquetes, assim como todos os demais

\footnotetext{
${ }^{56}$ A “agitação" como tradução de aestibus referencia às águas agitadas, à agitação do mar, sentido registrado nos dicionários (Agradeço ao Prof. Paulo Vasconcellos essa sugestão por ocasião do exame de qualificação).
} 
complexus, hilares compotationes caeteraque officia humanitatis. At, o rem indignam, apud hos nec umbram verae concordiae licuit cernere. Fucata fictaque omnia, factionibus apertis, clanculariis dissidiis ac simultatibus corrupta sunt universa. Denique adeo apud hos non esse sedem paci comperio, ut hinc potius omnium bellorum [140] fontes ac seminaria. Quo me posthac conferam infelix, posteaquam toties fefellit spes? At principes magni sunt potius quam eruditi magisque ducuntur cupiditatibus, quam recto animi iudicio.

[143] Ad eruditorum greges confugiam. Bonae litterae reddunt homines, philosophia plusquam homines, theologia reddit divos. Apud hos certe dabitur conquiescere [145] tot actae ambagibus. Verum proh dolor, en hic quoque bellorum aliud genus, minus quidem cruentum, sed tamen non minus insanum. Schola cum schola dissidet, et ceu rerum veritas loco commutetur, ita quaedam scita non traiiciunt mare, quaedam non superant Alpes, quaedam non tranant Rhenum, immo in eadem academia cum rhetore bellum est dialectico, cum iureconsulto [150] deveres da civilidade. Entretanto, ó coisa indigna! Junto a eles não é possível encontrar sequer a sombra da verdadeira concórdia. Tudo é fingido e simulado; não há nada que não seja corrompido por facções escancaradas ou por divergências e rivalidades ocultas. No final, não encontro o trono da paz entre eles, mas antes é aí que mais estão as fontes e origens de todas as guerras. Depois de tantas vezes ver perdida a esperança, para onde eu, infeliz, devo acorrer? Mas os príncipes talvez são mais importantes que eruditos; e mais se deixam conduzir pelas paixões do que pelo reto juízo da alma.

Refugiar-me-ei na grei dos eruditos: as boas letras formam os homens, a filosofia os torna mais do que homens e a teologia torna-os santos. Junto a eles, certamente, ser-me-á dado repousar, depois de me ter enredado em tantas digressões. Entretanto, ó dor! Aqui também há outro tipo de guerra, de fato menos cruenta, contudo não menos insana. Escolas se digladiam com escolas e como se a verdade mudasse com os lugares, certos conceitos não atravessam o mar, outros não transpõem os Alpes, outros, enfim, não cruzam o Reno, e até, na mesma Academia, o retórico disputa com o dialético ou o jurista discorda do teólogo. Chega-se ao ponto de que, no mesmo gênero de profissão, o tomista luta contra o escotista; ${ }^{57}$ o realista, contra o

\footnotetext{
${ }^{57}$ Cf. "Os traços do labirinto são menos complicados do que as tortuosas voltas dos realistas, nominalistas, tomistas, albertistas, occamistas, escotistas" (Elogio da Loucura, 53). Erasmo buscou o fundamento de sua doutrina nas fontes do cristianismo não nas "sutilezas" dos comentários variados e contraditórios dos filósofos medievais (cf. Margolin,1992, p. 918).
} 
dissidet theologus. Atque adeo in eodem professionis genere cum Thomista pugnat Scotista, cum Reali Nominalis, cum Peripatetico Platonicus, adeo ut ne in minutissimis quidem rebus inter hos conveniat ac saepenumero de lana caprina atrocissime digladientur, donec disputationis calor ab argumentis ad convitia, a convitiis ad pugnos incrudescat et si res pugionibus aut lanceis non [155] agitur, stilis veneno tinctis sese confodiunt, dentata charta dilacerant invicem, alter in alterius famam letalia linguarum vibrant spicula. Quo me vertam toties experta mihi data verba?

[158] Quid superest, nisi una veluti sacra ancora religio. Huius professio licet sit Christianorum omnium communis, tamen eam isti peculiariter profitentur titulo, [160] cultu, cerimoniis, qui vulgo Sacerdotum cognomento commendantur. Hos itaque procul intuenti cuncta spem faciunt portum mihi paratum esse. Arrident vestes candidae meoque colore insignes, video cruces pacis symbola, audio dulcissimum illud fratris cognomen, eximiae caritatis nominalista; o platônico, contra o peripatético, de tal forma que nem sequer concordam em ninharias e muitas vezes se digladiam violentamente por lã de caprina, ${ }^{58}$ até que o calor do debate recrudesce, e dos argumentos se passa às ofensas, das ofensas aos safanões ${ }^{59} \mathrm{e}$, se o assunto não se resolver com adagas e lanças, trespassam-se com penas envenenadas, dilaceram-se com papéis que mordem e um vibra o dardo mortal da língua contra o renome do outro. ${ }^{60}$ Para onde me voltarei, depois de tantas palavras enganosas que me foram dirigidas?

Que me resta, senão a religião, única âncora sagrada. Embora todos os cristãos, em geral, a professem, contudo alguns a professam de um modo peculiar, tanto pelo nome, como pelo tipo de vida e cerimônias que praticam, e que são aqueles a que vulgarmente se dá o nome de sacerdotes. Estes, observados assim à distância, tudo dá a esperança de que seja ali o porto preparado para mim. Suas vestes brancas sorriem, famosas pela minha cor; ${ }^{61}$ vejo as cruzes, símbolos da paz; ouço aquele dulcíssimo cognome de irmãos, demonstração de um amor

\footnotetext{
${ }^{58}$ Herding (1978, p. 67, nota 152-153) nota-se referência a Horácio (Epístola, I, 18, 15).

${ }^{59}$ Nota-se a referência a Cícero (Ad Quintum fratem. 2, 15, 6).

${ }^{60}$ A expressão "charta dentata" é um expressão ciceroniana (cf. Cicero. Ad Quintum fratem. 2,14,1).

${ }^{61}$ Cf. Ovídio. Ars amatoria. 3,502.
} 
argumentum, audio salutationes pacis, exímio; ouço as saudações de paz, cheias de laeto omine felices, cerno rerum omnium votos de felicidade; vejo a comunhão de todos os communionem, [165] coniunctum bens, um colegiado unido, o mesmo templo, as collegium, templum idem, leges easdem, mesmas leis e as reuniões diárias. Quem não conventus quotidianos. Quis hic non acreditaria ser este o lugar da paz? Mas, ó coisa confidat paci locum fore? Sed, o rem indigna! Quase não há uma ordem que concorde indignam, nusquam fere collegio com o bispo e, pior, cindem-se em facções. Quão convenit cum episcopo; parum hoc, nisi poucos são os sacerdotes que não estejam em et ipsi inter sese factionibus scinderentur. litígio com ao menos outro sacerdote? Paulo ${ }^{62}$ Quotusquisque sacerdos est, cui non sit não concorda que um cristão tenha disputas cum aliquo sacerdote lis? Paulus rem non contra outro cristão; ${ }^{63}$ e o sacerdote discute com ferendam censet, quod Christianus litiget o sacerdote, o bispo com o bispo! Mas há talvez adversus Christianum. [170] Et sacerdos cum sacerdote, episcopus cum episcopo certat? Verum his quoque forsitan ignoscat aliquis, quod longo iam usu propemodum in prophanorum consortium abierunt, posteaquam eadem cum illis coeperunt possidere. Age fruantur hii sane suo iure, quod ceu praescriptione sibi vindicant. Unum hominum genus superest qui sic adstricti sunt religioni, ut etiam si cupiant, [175] nullo pacto queant excutere, non magis profecto, quam testudo domum. Sperarem apud hos mihi fore locum, nisi toties frustrata spes me prorsus desperare docuisset. Et tamen ne quid intentatum relinquam, experiar. quem os desculpe, já que desde há muito tempo, quase se aproximaram do consórcio com o profano, depois de começarem a possuir as mesmas coisas que eles. Pois seja! Que usufruam, como se fosse direito seu aquilo que reivindicam como privilégio. Há ainda uma espécie de homems que estão de tal forma ligados a uma religião que, ainda que o quisessem, não conseguiriam deixá-la por nada, exatamente como ocorre com a tartaruga e seu casco. Esperaria encontrar junto a eles um lugar, se tantas esperanças frustadas não tivessem me ensinado a desesperar completamente. Mas, enfim, para não deixe algo a tentar, experimentarei. Queres saber o resultado? De ninguém tive de fugir mais rápido! Pois, o que se Quaeris exitum? A nullis resilii magis. poderia esperar de um lugar onde uma ordem

\footnotetext{
${ }^{62}$ Cf. II Ad Corinthum. 6,7.

${ }^{63}$ Cf. II Ad Corinthum. 6,7.
} 
Nam, quid sperem, ubi religio cum religiosa $^{64}$ discorda da outra? Tantas são as religione dissidet? Tot factiones sunt, facções quantas são as irmandades: os quot sunt sodalitia: Dominicales dissident dominicanos ${ }^{65}$ disputam com os minoritas, ${ }^{66}$ os cum Minoritis, [180] Benedictini cum beneditinos ${ }^{67}$ com os bernardinos ${ }^{68}$; tantos Bernardinis: tot nomina, tot cultus, tot nomes, tantos cultos, tantas cerimônias cerimoniae studio diversae, ne quid diferentes, de modo que não concordam em coisa omnino conveniret, sua cuique placent, alguma, cada um satisfeito com o que é seu, cada aliena damnat et oditque quisque. Quin um condenando e odiando o que é dos outros. idem sodalitium factionibus scinditur: Além disso, a mesma irmandade está dividida

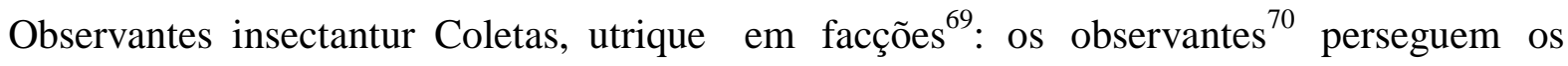
tertium genus, quod a conventu recoletas ${ }^{71}$, e uma terceira ordem deles, que tem cognomen habet, cum nihil inter istos o nome de conventual ${ }^{72}$, quando nada entre eles conveniat.

Iam, ut par est, omnibus rebus convém.

Já que é assim, desconfiada de todas as diffisa, optabam vel [185] in uno coisas, dispunha-me a ocultar-me em um quopiam monasteriolo latitare, quod vere tranquillum esset. Invita dicam, quod utinam non esset verissimum, nullum que quem dera não fosse muito verdadeiro: até adhuc reperi, quod non intestinis odiis ac hoje ainda não encontrei nenhum que não

${ }^{64}$ No original religio. Não se pode traduzir nesse caso religio, por religião. No tempo de Erasmo, chamava-se religião uma ordem religiosa específica diferentemente do sentido moderno que usa esse termo para outras religiões acatólicas. Erasmo chamava de religio o que hoje os teólogos chamam de carisma. Carisma é o vocábulo que se refere às características específicas dos indivíduos ou das ordens religiosas. Ademais, na teologia católica do século XVI só existia uma religião, a católica. É preciso lembrar que não havia acontecido ainda o simbólico feito de Lutero, que desencadeou a ruptura das igrejas reformadas com Roma.

65 Margolin $(1992,920)$ comenta que neste trecho, "Erasmo logo aproveita a ocasião de se queixar dos dominicanos, sobretudo os espanhóis, cuja estrita ortodoxia não se acomoda ao seu espírito reformista”.

${ }^{66}$ Menores ou freis menores, cuja ordem foi fundada em 1223 por São Francisco de Assis.

${ }^{67}$ Ordem religiosa fundada por São Bento por volta do ano 528 sobre o Monte Cassino, Itália.

${ }^{68}$ Religiosos cistercienses cuja ordem foi fundada em 1098 por Roberto de Citeaux, posteriormente reforma em 1119 pelo seu sucessor São Bernardo de Claraval.

${ }^{69}$ Dissensão da ordem franciscana instituída pelo Papa Leão X através da bula Ite vos in vineam meam (1517).

${ }^{70}$ Ordem fundada durante o Concílio de Constança (1415) e confirmada pelo Papa Martinho V (1420). A regra é mais restrita do que dos conventuais.

${ }^{71}$ Ordem fundada por Nicollete Boylet ao norte da França.

72 Ordem dos Frades Menores Conventuais, surgida entre os anos de 1249 e 1250, que predicava uma vida mendicante dentro dos conventos em oposição ao modo de vida itinerante. 
iurgiis esset infectum. Pudor sit recensere, quam nihili de nugis tricisque quantas cieant pugnas viri senes, barba pallioque verendi, postremo, ut sibi videntur, impense tum eruditi, tum sancti. Arridebat spes nonnulla [190] fore, ut alicubi inter tot coniugia qualiscumque daretur locus.

Quid enim non pollicetur domus communis, fortuna communis, lectus communis, liberi communes? Denique corporum ipsorum ius mutuum, ut unum potius hominem credas e duobus conflatum, quam duos? Huc quoque sceleratissima illa Eris irrepsit, totque vinculis copulatos dirimit dissidiis animorum. Et tamen inter [195] hos citius contingat locus, quam inter eos, qui tot titulis, tot insignibus, tot cerimoniis absolutam caritatem profitentur. Tandem illud in votis esse coepit, ut saltem in unius hominis pectore daretur locus. $\mathrm{Ne}$ id quidem contigit, idem homo secum pugnat. Ratio belligeratur cum affectibus, et insuper affectus cum affectu conflictatur, dum alio vocat pietas, alio trahit cupiditas. Rursum aliud [200] suadet libido, aliud ira, aliud ambitio, aliud avaritia. Et huiusmodi cum sint, non pudet tamen illos appellari Christianos, cum modis omnibus dissideant ab eo, estivesse contaminado por essas discórdias e ódios intestinos. É uma vergonha contar quantas lutas, por causa de bagatelas e futilidades totalmente insignificantes, são causadas por anciãos, venerandos em suas barbas e hábitos, e que persistem em se ver a si mesmos tão eruditos, tão santos. Sorria-me a esperança de que haveria de encontrar um abrigo em algum lugar, entre tantos casais.

Que outra coisa poderia prometer-me um lar comum, de uma sorte comum, de um leito comum e de filhos comuns? Enfim, do direito mútuo aos próprios corpos, a tal ponto que nos é permitido crer que, em lugar de dois seres, se trata mais propriamente de um, formado a partir de dois? Também aqui penetrou aquela tão perversa Éris e separou com dissensões pessoas que estavam ligadas por muitos vínculos. E, contudo, com mais rapidez se consegue um lugar entre estes do que entre aqueles outros que, com tantos títulos, tantas insígnias, tantas cerimônias professam uma caridade absoluta. Finalmente, comecei a ter o desejo de que ao menos fosse dado um lugar no coração de um único homem. Mas também aí não fui bem sucedida, pois o mesmo homem luta contra si mesmo. A razão luta contra os sentimentos e, ademais, os sentimentos lutam entre si: se a piedade impele numa direção, o desejo arrasta para outra; ademais, a libido aconselha uma coisa, a ira outra, a ambição outra, a avareza outra. Mas, mesmo assim, não se envergonham de chamar-se 
quod Christo praecipuum est ac peculiare.

[203] Universam eius vitam contemplare: quid aliud est, quam concordiae mutuique amoris doctrina? Quid aliud inculcant eius praecepta, quid parabolae, nisi [205] pacem, nisi caritatem mutuam? Egregius ille vates Esaias, cum coelesti afflatus spiritu Christum illum rerum omnium conciliatorem venturum annunciaret, num satrapam pollicetur, num urbium eversorem, num bellatorem, num triumphatorem? Nequaquam. Quid igitur? Principem Pacis; siquidem cura omnium optimum principem intelligi vellet, $a b$ ea re denotavit, quam omnium [210] optimam iudicasset. Neque mirum ita visum Esaiae, cum Silius Ethnicus Poeta hunc in modum de me scripserit: Pax optima rerum, quas homini natura dedit. Concinit huic mysticus ille citharoedus: et factus est, inquiens, in pace locus eius. In pace dixit, non in tentoriis, non in castris, princeps est pacis, pacem amat, offenditur dissidio. Rursum Esaias opus iustitiae pacem cristãos, embora se afastem daquilo que é principal e peculiar em Cristo.

Contempla toda a vida dele: que outra coisa é ela, senão um ensinamento de concórdia e de amor mútuo? Que outra coisa inculcam os seus preceitos e suas parábolas, a não ser a paz, a não ser a mútua caridade? $O$ grande profeta Isaías, ao anunciar, inspirado pelo Espírito Celeste, que Cristo haveria de vir como conciliador de todas as criaturas, teria por acaso prometido um sátrapa ou um agitador de cidades, ou um guerreiro, ou um triunfador? De modo algum! O quê, então? O príncipe da Paz! Pois, como tinha a intenção de referir-se ao príncipe por excelência, descreveu-o por aquela coisa que é a mais excelente de todas. Não admira que tal tenha sido a opinião de Isaías, porque até um poeta pagão, Sílio, escreveu deste modo sobre mim: "a paz é o dom mais excelente que a natureza concedeu ao homem". ${ }^{73}$ Aquele famoso místico citarista cantou a meu respeito, ao dizer: “E fez seu assento na paz". 74 "Na paz", disse ele, não em tendas, não em acampamentos. É o Príncipe da paz. Ele ama a paz, ofende-se com a discórdia. E novamente Isaías: “à justiça chamase obra da paz", ${ }^{75}$ pensando, se é que não me engano, o mesmo que pensou Paulo, que, outrora

\footnotetext{
${ }^{74}$ Erasmo cita o texto bíblico do Psalmo 75,3 da Vulgata (séc. IV) atribuído a Eusebius Sophronius Hieronymus (347-420) mais conhecido como São Jerônimo: "Et factus est in pace locus eius". Para os textos citados do Novo Testamento, Erasmo cita sua própria tradução latina.

75 Erasmo parafraseia a tradução de Jerônimo “Opus iustitiae pax” de um trecho de Isaiah 32,17.
} 
appellat, idem sentiens, [215] ni fallor, violento Saulo, ${ }^{76}$ converteu-se em pacífico e quod sensit Paulus ille, et ipse e Saulo mestre da paz, sobrepondo a caridade acima de turbulento redditus tranquillus et pacis todos os outros dons do Espírito Santo; com que doctor. Cum caritatem caeteris omnibus coração, com que eloquência entoou meu elogio arcani spiritus dotibus anteponens, quo aos coríntios! $!^{77}$ Por que eu não me gloriaria de pectore, qua facundia meum encomium ser elogiada por um varão tão louvado? Ora me detonuit Corinthiis. Cur enim non glorier chama "o Deus da paz" 78 , ora invoca "a paz de sic laudari a viro tam laudato? Is alias deum pacis appellat, alias pacem dei vocat, palam indicans haec duo sic inter sese cohaerere, ut ibi pax esse non possit, ubi deus non adsit nec illic esse deus possit, ubi pax non [220] adsit. Itidem et pacis angelos in divinis libris vocatos legimus pios ac dei ministros, ut per se liqueat, quos belli Angelos oporteat accipi.

Deus" ${ }^{79}$, indicando claramente que esses dois conceitos estão interligados de tal forma que, onde há paz, Deus se faz presente; e Deus não se faz presente, onde não existe paz. Do mesmo modo, podemos ler nas Escrituras Sagradas que os homens piedosos e os ministros de Deus são chamados mensageiros da $\mathrm{paz}^{80}$, a fim de que por si mesmo fique evidente quais são aqueles que devemos entender como mensageiros da guerra.

Ouvi isto, poderosos guerreiros! Vede sob que estandarte militais! Sem dúvida daquele

[223] Audite strenui bellatores. Videte sub cuius signis militetis, nimirum que primeiro semeou a discórdia entre Deus e o homem $^{81}$. A este primeiro conflito devem ser illius, qui primus dissidium sevit inter atribuídas todas as calamidades que a deum et hominem. Quicquid calamitatum humanidade sofre. É ridículo o que alguns sentit mortalitas, huic dissidio debet argumentam, de que nas Sagradas Escrituras se

\footnotetext{
${ }^{76}$ Paulo, então chamado de Saulo, "respirava ameaças e ódio contra os cristãos” (Acta apostolorum, 9,1).

77 "Non enim est dissensionis Deus sed pacis sicut in omnibus ecclesiis sanctorum" (Prima ad Corinthians 14,33); "in pace autem vocavit nos Deus" (Prima ad Corinthians 7,15), "sapite pacem habete et Deus dilectionis et pacis erit vobiscum" (Secunda ad Corinthians 13, 11).

${ }^{78}$ Deus Pacis. Erasmo recorre mais uma vez à tradução de Jerônimo para Prima ad Thessalonicenses 5,23 e Ad Philipenses 4,9. Segundo Margolin (1992, p. 922), Paulo utilizada a expressão Deus pacis em várias passagens (Ad Romanos 15,33; 16,20; Ad Corinthios I, 14,33; Ad Corinthios II 13,11; Ad Philipenses, 4,9. Ad Tessalonicenses I 5,23; Ad Hebraeos , 13,20).

79 "Pax Dei" (Ad Philipenses 4,7).

80 "Ecce praecones clamabunt foris, angeli pacis amare flebunt" (Isaiah 33,7).

${ }^{81}$ Erasmo parece evocar a metáfora da serpente do paraíso descrita nos capítulos iniciais do Genesis.
} 
acceptum ferre. Frivolum est enim, quod argutantur quidam, in arcanis litteris deum exercituum et deum ultionum dici. Permultum enim interest inter Iudaeorum deum et Christianorum deum, etiamsi suapte natura unus et idem deus est. Aut si nobis quoque placent tituli veteres, age sit exercituum deus, modo acies intelligas virtutum concentum, quarum [230] praesidio vitia demoliuntur homines pii. Sit ultionum Deus, modo vindictam accipias, vitiorum correctionem, ut cruentas strages, quibus Hebraeorum libri referti sunt, non ad laniandos homines, sed ad impios affectus e pectore profligandos referas. Sed ut quod institutum erat, persequamur: quoties absolutam felicitatem significant arcanae litterae, pacis nomine id faciunt, velut Esaias: [235] Sedebit, inquit, populus meus in pulcritudine pacis. Et alius: Pax, inquit, super Israel. Rursum, Esaias admiratur pedes annunciantium pacem, boas. $^{86}$ annunciantium bona.

Quem quer que anuncie a Cristo, anuncia a paz. Quem quer que pregue a guerra, prega Quisquis Christum annunciat, aquele que é o que mais se diferencia de Cristo. pacem annunciat. Quisquis bellum Pois vejamos! Que outra coisa buscou o Filho de

\footnotetext{
${ }^{82} \mathrm{Na}$ Vulgata de Jerônimo a expressão Deus exercituum consta sessenta e cinco vezes, todas no Antigo Testamento.

${ }^{83}$ Na Vulgata a expressão Deus ultionum só é usada uma vez no Salmo 93,1.

84 “Sedebit, inquit, populus meus in pulcritudine pacis" (Isaiah 32,18).

85 “Pax super Israel” (Psalmus 124,5; Psalmus 127,6; Ad Galatas 6,16).

86 "Quam pulchri super montes pedes adnuntiantis et praedicantis pacem bonum praedicantis" (Isaiah 52,7).
} 
praedicat, illum praedicat, qui Christi dissimillimus est. Age iam quae res dei filium pellexit in terras, nisi ut mundum patri reconciliaret, ut homines inter se mutua et [240] indissolubili caritate conglutinaret, postremo, ut ipsum hominem sibi faceret amicum? Mea igitur gratia legatus erat, meum agebat negotium. Atque ob id Solomonem sui

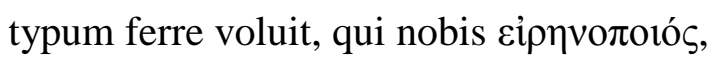
id est pacificus, dicitur. Quantumuis magnus erat David, tamen quia bellator erat, quia sanguine fuerat impiatus, non sinitur exstruere domum domini. Non meretur hac [240] parte gerere typum Christi pacifici. Iam illud interim perpende bellator: si profanant bella numinis iussu suscepta gestaque, quid facient quae suasit ambitio, quae ira, quae furor? Si pium regem polluit effusus sanguis ethnicorum, quid faciet tam ingens effusio sanguinis Christiani?

[249] Obsecro te Christiane
Deus nesta terra senão que o mundo se reconciliasse com o Pai? Que os homens se unissem entre si por uma mútua e indissolúvel caridade? Em suma, para fazer-se amigo do próprio homem? Assim, portanto, Cristo fora enviado por minha causa e tomava conta de mim. Por isso constituiu como sua imagem o rei

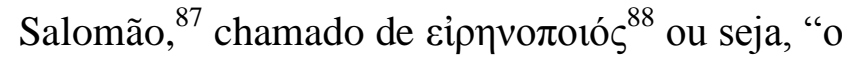
pacífico". Grandioso e ilustre era Davi, ${ }^{89}$ mas, porque era guerreiro, porque tinha sido maculado pelo sangue, não lhe foi autorizado construir a casa do Senhor, nem foi merecedor, por isso, de ser a imagem do Cristo Pacífico. Presta bem atenção, ó homem guerreiro! Se as guerras que foram feitas e perpretadas por ordem da divindade profanam, que farão aquelas que a ambição, a ira e a loucura aconselharam? Se o sangue dos pagãos que derramou foi capaz de macular um rei tão piedoso, o que poderá fazer este enorme derramamento de sangue cristão? ${ }^{90}$ Imploro-te, ó Príncipe Cristão, se verdadeiramente és cristão, que contemples o exemplo do príncipe por excelência; observa

\footnotetext{
${ }^{87}$ Erasmo evoca a etimologia do nome Solomon, pacífico que, de acordo com o livro dos Reis e das Crônicas seria filho do rei Davi. Reinou sobre Israel entre 970 e 931 a. C.. Construiu o primeiro templo de Jerusalém, teria sido o autor de alguns livros bíblicos e célebre pelo dom de sabedoria.

88 "Filius qui nascetur tibi et erit vir quietissimus faciam enim eum requiescere ab omnibus inimicis suis per circuitum et ob hanc causam pacificus vocabitur et pacem et otium dabo in Israhel cunctis diebus eius" (Primus Paralipomenon 22, 9).

${ }^{89}$ David reinou sobre Judá entre 1010 e 1002 a. C. e sobre o reino unido de Israel entre 1002 e 970 a C. Tronouse célebre como guerreiro, comandante, músico e poeta se lhe atribui a autoria da maioria dos salmos. Teria sido castigado pelo adultério com Bersabeia seguido do assassinato do esposo dela, Urias.

${ }^{90}$ Percebe-se que Erasmo fala de uma guerra inserida em seu presente ou em passado muito próximo. Segundo evidências históricas, ele se refere à guerra da Liga de Cambrai ou Liga Santa que envolveu os principais estados europeus durante os anos de 1508 a 1516.
} 
Princeps, si modo vere Christianus es, como ele iniciou e desenvolveu o seu reinado, contemplare [250] tui principis como ele daqui partiu e imediatamente imaginem, observa quomodo regnum aprenderás como é necessário que o administres, suum inierit, quomodo progressus sit, de forma que, sem dúvida alguma, a paz e a quomodo hinc decesserit, et mox concórdia sejam o principal objeto de tuas intelliges quomodo abs te geri velit, preocupações. Assim que o Cristo nasceu, os nimirum ut summa curarum tuarum pax Anjos, por acaso, tocaram as trombetas de sit, et concordia. Nato iam Christo num bellicis tubis insonant angeli? Clangorem tubarum audiere Iudaei, quibus bellare permissum est. Haec congruebant auspicia, quibus fas erat odisse [255] inimicos. At genti pacificae longe aliam cantionem canunt pacis angeli. Num classicum canunt, num victorias, triumphos, trophaeaque pollicentur? Minime. Quid tandem? Pacem annunciant congruentes cum prophetarum oraculis et annunciant non iis, qui caedes spirant ac bella, qui feroces ad arma gestiunt, sed qui bona voluntate propensi sint ad concordiam. Praetexant quae velint suo [260] morbo mortales: ni bellum amarent, non sic iugibus bellis inter se conflictarentur. Age Christus ipse iam adultus, quid aliud docuit, quid aliud expressit quam pacem? Pacis omine suos subinde salutat: Pax vobis eamque salutandi formam suis praescribit veluti unice dignam Christianis. Atque huius guerra? Somente os judeus, a quem era permitido guerrear, ouviam os sons das trombetas. Estes auspícios eram compreenssíveis na época em que a lei mosaica legitimava o ódio aos inimigos, mas os anjos da paz devem entoar um canto totalmente diferente para os povos pacíficos. Por acaso tocam o clarim? Por acaso prometem vitórias, triunfos e troféus? Jamais! O quê, então? Anunciam a paz, conforme os oráculos dos profetas, e a anunciam não àqueles que aspiram a assassinatos e guerras e que anseiam ferozmente pelas armas, mas àqueles que, com boa vontade, são propensos à concórdia. Que os mortais desculpem com sua fraqueza o que quiserem, mas se, de fato, não amassem a guerra, não lutariam de tal modo entre si com batalhas contínuas. Olhai para o Cristo já adulto! Que outra coisa ensinou, que outra coisa expressou, senão a paz? Além disso, ele saúda os seus discípulos com o cumprimento da paz: "a paz esteja convosco","91 e lhes prescreveu essa forma de saudação como a única digna dos cristãos. Os apóstolos não se

\footnotetext{
91 “Pax vobis" (Ioannes20,19.21.26; Lucas 24,36).
} 
praecepti non immemores apostoli pacem praefantur in suis epistolis, pacem optant iis, quos [265] unice diligunt. Rem praeclaram optat, qui salutem optat, sed felicitatis summam precatur. Hanc ille toties in omni vita commendatam, vide quanta sollicitudine commendet moriturus: Diligatis, inquit, invicem sicut dilexi vos. Ac rursum: Pacem meam do vobis, pacem relinquo vobis.

[269] Auditis quid relinquat suis? Num equos, num satellitium, num imperium, num opes? Nihil horum. Quid igitur? Pacem dat, pacem relinquit, pacem cum amicis, pacem cum inimicis. Iam illud mihi consyderes velim, quid a coena mystica, iam imminente mortis tempore, supremis illis precibus flagitarit a patre. Rem opinor haud vulgarem poposcit, qui se sciebat impetraturum quicquid peteret. Pater, inquit, sancte, serva eos in nomine tuo, ut sint unum, sicut et nos. Vide, quaeso, quam insignem concordiam exigat in suis Christus. Non dixit, ut sint unanimes, sed ut sint unum neque id quocumque modo, esqueceram desses preceitos, e recomendavam a paz em suas cartas, e desejavam paz àqueles a que amavam de forma especial. Escolhe coisa importante, quem faz votos pela saúde, mas está desejando o sumo da felicidade. Ele, que a tinha recomendado durante toda a sua vida, nunca deixou de a recomendar. Veja com quão grande solicitude a recomenda quando estava prestes a morrer: "Amai-vos uns aos outros, como eu vos tenho amado". 92 E novamente: "eu vos deixo a paz, eu vos dou a minha paz".93

Ouvis o que Cristo deixou para os seus? Cavalos? Escoltas? Poder? Riquezas? Nada disso. O quê, então? Cristo lhes dá a paz, lhes deixa a paz. Paz com os amigos, paz com os inimigos. Gostaria também que considerasses comigo o que, já no tempo em que a sua morte era iminente, ele suplicou ao Pai com aquelas suas últimas preces, na mística ceia. Suponho que não pediu algo usual, pois sabia que haveria de obter qualquer coisa que pedisse. Disse: "Pai santo, guarda-os em teu nome, para que sejam um, como nós”. Veja, por favor, quão insígne é a concórdia que Cristo solicita para seus discípulos: ele não disse "para que eles sejam unânimes", mas "que sejam um só"; e isso não de qualquer forma, mas "como nós somos um, nós que, de maneira perfeita e inefável, somos o mesmo", 94 indicando, assim, que só alimentando

\footnotetext{
92 "Sicut dilexit me Pater et ego dilexi vos manete in dilectione mea" (Ioannes 15,9).

93 "Pacem relinquo vobis pacem meam do vobis" (Ioannes 14,27).

94 "Pater sancte serva eos in nomine tuo quos dedisti mihi ut sint unum sicut et nos" (Ioannes 17,11)
} 
sed sicuti nos, inquit, unum sumus, qui perfectissima et ineffabili ratione sumus idem, et illud obiter indicans hac una via servandos esse mortales, si mutuam inter sese pacem aluerint. Porro quod huius mundi principes insigni quopiam suos notant, [280] quo possint a caeteris dignosci, praesertim in bello, vide qua tandem nota Christus insignierit suos, non alia videlicet quam mutuae caritatis. Hoc, inquiens, argumento cognoscent homines vos esse meos discipulos, non si sic aut sic vestiamini, non si his aut his vescamini cibis, non si tantum ieiunetis, non si tantum psalmorum exhauseritis, sed si dilexeritis invicem, neque id sane vulgari [285] modo, sed quemadmodum ego dilexi vos. Innumera sunt philosophorum praecepta, varia sunt: Moysi, plurima regum edicta, unicum est, inquit, praceptum meum, ut ametis invicem. Idem orandi formam suis praescribens nonne in ipso statim initio mire admonet concordiae Christianae? Pater, inquit, noster. Unius est precatio, una communis omnium est postulatio, una domus, eademque [290] familia sunt omnes, ab uno patre pendent omnes. Et qui convenit eos iugibus bellis inter sese entre si uma paz recíproca é que os mortais poderão se salvar. Da mesma forma que os príncipes deste mundo assinalam seus súditos com uma marca, a fim de que possam reconhecêlos de imediato entre os demais, sobretudo na guerra, vê com que sinal Cristo distinguiu os seus: com o da mútua caridade. "Por este sinal", disse, "os homens reconhecerão que sois meus discípulos, não se vos vestirdes deste ou daquele modo, não se comerdes deste ou daquele alimento, não se jejuardes muito, não se recitardes grande número de salmos, mas se vos amardes uns aos outros, e não de uma forma usual, mas assim como eu vos amei". 95 Incontáveis são os preceitos dos filósofos, numerosos são os de Moisés, muitos os éditos dos reis, mas diz ele: “o meu preceito é um só: amai-vos uns aos outros". ${ }^{96}$ Por isso, ao ensinar a seus discípulos a fórmula da oração, Cristo já não quis logo de inícioadvogar para a concórdia cristã? Diz: "Pai Nosso" 97 . A oração é de um só, um único pedido comum de todos, um só lar, e todos são uma mesma família, todos dependem de um só Pai. Como é possível que em guerras perpétuas se combatam entre si? Como é possível que interpeles o Pai comum, se atravessas com a espada as vísceras do teu irmão? Por que quis arraigar nas mentes dos seus discípulos sobretudo isso? Com quantos

\footnotetext{
${ }^{95}$ Cf. Ioannes $15,12$.

96 "Hoc est praeceptum meum ut diligatis invicem sicut dilexi vos" (Ioannes 15,12).

97 "Pater Noster" (Matheus 6,9).
} 
conflictari? Quo ore compellas communem patrem, si in fratris tui viscera ferrum stringis? Iam quoniam unum hoc voluit altissime insidere suorum animis, quot symbolis, quot parabolis, quot praeceptis concordiae studium inculcavit? Se pastorem vocat, suos oves. Et, obsecro, quis umquam [295] vidit oves pugnantes cum ovibus? Aut quid faciunt lupi, si grex ipse semet invicem lacerat? Cum se vitis stirpem vocat, suos vero palmites, quid aliud quam expressit unanimitatem? Portentum videatur piaculis procurandum, si in eadem vite palmes cum palmite bellet, et ostentum non est, si Christianus pugnet cum Christiano? Postremo si quid omnino Christianis sacrosanctum est, [300] certe sacrosanctum esse debet, ac penitus animis illorum insidere, quae Christus extremis illis mandatis tradidit, veluti testamentum condens, ac filiis ea commendans, quae cuperet illis numquam venire in oblivionem. Aut quid aliud in his docet, mandat, praecipit, orat, nisi mutuum inter ipsos amorem? Quid illa sacrosancti panis, et calicis philotesii communio, nisi novam quamdam et indissolubilem [305] concordiam sanxit? Caeterum quando sciebat non posse constare pacem, ubi de magistratu, de gloria, de opibus, de vindicta certamen símbolos, com quantas parábolas, com quantos preceitos instruiu o amor da concórdia? Cristo chama-se a si mesmo pastor, e aos seus, ovelhas. Ora, eu pergunto: alguém porventura já viu ovelhas lutando com ovelhas? O que fariam os lobos, se o rebanho começasse a lutar entre si? Quando se chama a si mesmo a Videira, e aos seus, ramos, não quis dizer unidade? Se, na mesma videira, um ramo guerreasse contra outro ramo, não pareceria isso espantoso, que deveria ser conjurado com sacrifícios expiatórios; e por acaso não se trata de um prodígio que um cristão lute com cristão? Por fim, há algo de mais sagrado para os cristãos, certamente deve ser sagrado e penetrar no interior das almas o que Cristo lhes transmitiu através daqueles últimos mandamentos, como que fazendo um testamento, aquilo que recomendou como a filhos e desejou que jamais caísse no esquecimento. Que outra coisa Cristo ensina, ordena, preceitua e roga ao Pai, senão que exista o amor mútuo entre os homens? Que outra coisa aquela comunhão do pão consagrado e do cálice do amor sancionou, senão uma nova concórdia indissolúvel? Ademais, uma vez que sabia não ser possível contar com a paz onde há lutas por causa de cargos, de glória, de riquezas, de litígios e de processos, arranca paixões dessa espécie completamente das almas dos seus, proíbe que eles sobretudo resistam ao mal, ordena que eles façam o bem àqueles que lhes fazem o mal e ainda que desejem o bem daqueles que lhes 
est, ut penitus affectus eiusmodi revellit ex animis suorum, vetat in totum, ne malo resistant, iubet ut de male merentibus bene mereantur; si possint, bene precentur male precantibus. Et Christiani sibi videntur, qui ob quantumuis levem iniuriolam, [310] magnam orbis partem in bellum pertrahunt? Praecipit, ut qui in suo populo sit princeps, is ministrum agat nec alia re praecellat aliis, nisi quod melior sit, et pluribus prosit. Et non pudet quosdam ob pusillam accessiunculam regni pomoeriis addendam tantos ciere tumultus? Docet avium et liliorum ritu in diem vivere. Vetat sollicitudinem in posterum diem extendere, vult totos e caelo [315] pendere, divites omnes excludit a regno caelorum, et non verentur quidam ob pecuniolam non exsolutam, fortasse nec debitam, tantum humani sanguinis effundere. Atque his temporibus hae vel iustissimae suscipiendi belli causae videntur. o irmão, porventura não ensina abertamente que Profecto haud aliud agit Christus iubens, a concórdia deve anteceder a todas as coisas e ut unum quiddam a se discant: miti esse animo, minimeque feroci, cum iubet relinqui donarium ad aram nec [320] prius offerri, quam cum fratre reditum sit desejam o mal. E veem-se como cristãos aqueles que, por causa de uma leve injuriazinha, levam à guerra uma grande parte do mundo? Ordena que o príncipe se comporte como um servo, e que em nada supere os outros, a não ser por ser o melhor e o mais útil para a maioria. E os príncipes deste mundo, por pequeninas aquisições territoriais ou para acrescentar ao reino alguns pomérios, não se envergonham de criar tamanha turbação? Ensina a viver o dia, como as aves e os lírios. Proíbe-nos de preocupar-nos de forma demasiada com o dia de amanhã ${ }^{98}$ quer que todos dependamos apenas do céu, exclui todos os ricos do reino dos céus; e há quem, por uma pequena dívida não saldada, talvez nem mesmo devida, derrame tanto sangue humano? Ora, estes talvez pareçam hoje em dia motivos justíssimos para se fazer a guerra. Mas acaso Cristo não age de forma contrária, ordenando que cada qual aprenda dele uma só coisa: a ter um espírito manso, nada feroz? Quando ordena que a oferenda seja depositada no altar e que não seja oferecida senão depois da reconciliação com que nenhuma oferenda é agradável a Deus se não for recomendada por mim? Deus rejeitava as oferendas judaicas, que eram bodes ou ovelhas, porque eram oferecidas por homens que viviam

\footnotetext{
${ }^{98}$ A paz relembra o capítulo sexto do Evangelho de Marcos no qual Cristo teria enviado os Doze, dois a dois; ordenando-lhes que não levassem coisa alguma para o caminho nem pão, nem mochila, nem dinheiro no cinto, mas somente um bordão; como calçado, unicamente sandálias, e que se não revestissem de duas túnicas.
} 
in gratiam; nonne palam docet rebus omnibus anteponendam esse concordiam nec ullam victimam esse deo gratam, nisi commendante me? Respuebat deus Iudaicum munus, fortassis haedum, aut ovem, quod a dissidentibus offerretur, et Christiani sic inter sese belligerantes sacrosanctam illam victimam audent offerre? Iam cum se gallinae pullos sub [325] alas aggreganti facit adsimilem, quam apto symbolo depinxit concordiam. Ille congregator est, et qui convertit Christianos esse milvios? Eodem pertinet quod lapis dictus est angularis utrumque parietem committens et continens, et qui convenit ut huius vicarii totum orbem ad arma commoveant regnaque regnis committant? Summum illum conciliatorem habent principem, ut iactant, et [330] nullis rationibus ipsi sibi possunt reconciliari. Conciliavit ille Pilatum et Herodem, et suos in concordiam redigere non potest? Petrum adhuc semiiudaeum, qui in praesentis capitis discrimine dominum ac praeceptorem tueri parabat, obiurgat ipse qui defendebatur, gladiumque iubet recondere, et Christianis ob levissimas causas numquam non expromptus districtusque est gladius idque in [335] em discórdia: e como ousam os cristãos, que guerreiam entre si, ofertar aquele sacrifício sagrado? Quão apropriada é a imagem com que ele retratou a concórdia, ao fazer uma comparação entre si mesmo e a galinha que junta os pintinhos sob as asas! Ele é o congregador, e os cristãos serão aves de rapina? Pelo mesmo motivo é chamado pedra angular, que ao mesmo tempo une e mantém duas paredes; e serão aqueles que ocupam o lugar dele na terra os que movem todo orbe às armas e incitam reinos contra reinos? Jactam-se de que têm como Príncipe aquele sumo conciliador, mas se mostram incapazes de ser por ele reconciliados. Ele conciliou Pilatos e Herodes, e não pode conduzir os seus à concórdia? E ainda a Pedro (um meio judeu, que, diante de um perigo mortal, quis defender o seu Senhor e Mestre) Cristo repreendeu e ordenou àquele que o defendia, que a espada fosse guardada. ${ }^{99} \mathrm{E}$ os cristãos, por causa de questões ligeiríssimas, têm sempre a espada desembainhada e pronta contra os próprios cristãos? Por acaso desejaria ser defendido pela proteção da espada aquele que, ao morrer, pediu perdão pelos autores do crime?

\footnotetext{
${ }^{99}$ Erasmo se refere ao episódio no qual Pedro atacou com uma espada um dos soldados que prendiam Jesus (Cf. Matheus 26,51; Marcus 14,47; Lucas 22,50-51; Ioannes 18,10).
} 
Christianos. An ille se gladii praesidio defensum velit, qui moriens deprecatur pro necis auctoribus?

[337] Omnes Christianorum litterae, sive vetus legas testamentum, sive novum, nihil aliud quam pacem et unanimitatem crepant, et omnis Christianorum vita nihil aliud quam bella tractat. Quaenam est haec plusquam ferina feritas, [340] quae tot rebus nec vinci potest nec leniri? Quin potius aut Christianorum titulo gloriari desinant aut Christi doctrinam exprimant concordia. Quousque vita pugnabit cum nomine? Insignite quantumlibet aedes vestesque crucis imagine, non agnoscet Christus symbolum, nisi quod ipse praescripsit, videlicet concordiae. Congregati vident euntem in caelum, congregati iubentur operiri spiritum [345] caelestem. Et inter congregatos se semper versaturum promiserat, ne quis speraret usquam in bellis adesse Christum. Iam igneus ille spiritus, quid aliud est quam caritas? Nihil igne communius, citra dispendium ullum ignis igni accenditur. Vis autem cognoscere spiritum illum concordiae parentem esse? Exitum vide. Erat, inquit, cunctis cor unum et anima una. [350] Tolle spiritum e corpore, teólogos afirmam que hoje o Espírito Celeste se se lês o Antigo Testamento, ou o Novo, clamam nada mais do que a paz e a unidade; e a vida toda dos cristãos nada mais é do que ocupar-se da guerra? Que ferocidade mais que bestial é esta, que nem pode ser vencida nem ser amenizada com tão grande número de antídotos? É melhor que optem: ou desistem de se gloriar do título de cristãos ou imitam, vivendo em concórdia, a doutrina de Cristo. Até quando a vida contradirá o nome? Ainda que ornamenteis e assinaleis com a imagem da cruz os templos e as vestes, Cristo não reconhecerá como seu sinal senão aquele que ele mesmo prescreveu, ou seja, o sinal da concórdia. Congregados viram-no subir ao Céu; congregados foram chamados a receber $\mathrm{o}$ Espírito Santo. E havia prometido que sempre haveria de encontrar-se no meio daqueles que estivessem congregados, para ninguém esperar que Cristo esteja presente nas guerras. Já aquele espírito ígneo que outra coisa é senão amor? Nada é mais comum do que o fogo, pois, sem demora, fogo é aceso pelo fogo. Queres saber como aquele espírito gerava a concórdia? Vê o resultado. Ele diz: “eram todos um só coração e uma só alma". 100

Tira o espírito do corpo e imediatamente dissolve-se toda aquela ligação dos membros. Tira a paz, e perecerá toda a sociedade cristã. Os

100 "Multitudinis autem credentium erat cor et anima una" (Acta Apostolorum 4, 32). 
continuo dilabitur omnis illa membrorum compago; tolle pacem, et perit omnis Christianae vitae societas. Tot hodie sacramentis infundi caelestem spiritum affirmant theologi. Si verum praedicant, ubi peculiaris spiritus illius effectus: cor unum et anima una? Sin fabulae sunt, cur tantam honoris hisce rebus defertur? Atque haec sane dixerim, quo magis Christianos [355] suorum morum pudeat, non quo sacramentis aliquid detraham. Nam quod populum Christianum ecclesiam vocari placuit, quid aliud quam unanimitatis admonet? Qui convenit castris et ecclesiae? Haec aggregationem sonat, illa dissidium. Si pars Ecclesiae gloriaris esse, quid tibi cum bellis? $\mathrm{Si}$ ab Ecclesia semotus es, quid tibi cum Christo? Si eadem omnes habet domus, si communem [360] habetis principem, si eidem militatis omneis (sic), si sacramentis iisdem estis initiati, si iisdem gaudetis donativis, si iisdem alimini stipendiis, si commune petitur praemium, quid ita inter vos tumultuamini? Videmus inter impios istos commilitones, qui mercede ad caedis peragendae ministerium conducti veniunt tantam esse concordiam non ob aliud, nisi quod sub iisdem militant signis, et [365] pietatem profitentes tot res non conglutinant. Itane nihil agitur tot sacramentis? Baptismus infunde em nós por um grande número de sacramentos. Se de fato pregam a verdade, onde está o efeito particular daquele espírito, a saber, um só coração e uma só alma? Se os sacramentos não passam de fábulas, por que se lhes confere tanta honra? Se o disse assim dessa maneira, não foi para depreciar em coisa alguma os sacramentos, mas a fim de que os cristãos mais possam envergonhar-se de seus maus costumes. Aquilo que o povo cristão agradou-se em chamar Igreja, não foi para aconselhar a unidade? Como conciliar exército e Igreja? Esta soa união, aquele, divisão; se te glorias de ser parte da Igreja, que tens tu a ver com as guerras? Se te afastaste da Igreja, que tens tu com Cristo? Se todos possuís o mesmo lar, se tendes um Príncipe comum, se militais todos sob o mesmo estandarte, se fostes iniciados nos mesmos sacramentos, se vos alegrais com os mesmos dons, se sois alimentados graças aos mesmos recursos, se buscais o mesmo prêmio, por que vos enfrentais assim entre vós? Vemos enorme concórdia entre os ímpios mercenários, que são levados pela esperança de prêmio ao serviço de perpetrar assassinatos, isso ocorre não por outra coisa, senão porque lutam sob os mesmos estandartes; por que, então, tão grande número de benefícios não une aqueles que professam a piedade? Serão tão ineficazes tantos sacramentos? O batismo comum a todos, através do qual renascemos com Cristo e, libertados do mundo, somos inseridos como membros de 
communis omnium, per hunc Christo Cristo. Ora, que comunhão maior pode haver que renascimur et exsecti mundo Christi a dos membros do mesmo corpo? A partir daí, membris inserimur. Quid autem tam idem não há mais servos e homens livres; bárbaros e esse potest quam eiusdem corporis gregos; homens e mulheres; mas todos são o membra? Ab hoc igitur neque servus est mesmo em Cristo, ${ }^{101}$ que tudo conduziu à quisquam neque liber neque barbarus concórdia. ${ }^{102}$ neque Graecus neque vir neque foemina, Um pouco de sangue bebido de um sed omnes idem in Christo [370] sunt, qui omnia redigit in concordiam.

[371] Scythas ita iungit paululum sanguinis utrimque gustati e calice, ut pro amico nihil cunctentur et mortem oppetere. Ethnicis etiam sancta est amicitia, quam mensa communis conciliavit, et Christianos caelestis ille panis ac mysticus ille calix non continet in amicitia, quam ipse sanxit Christus, quam illi quotidie [375] renovant, ac repraesentant sacrificiis? Si nihil illic egit Christus, quorsum opus hodie tot cerimoniis? Si rem seriam egit, cur sic a vobis negligitur, quasi rem ludicram ac scenicam egerit? Audet quisquam ad sacram illam mensam amicitiae symbolum, audet ad pacis convivium accedere, qui bellum destinat in daqueles em favor dos quais o Cristo derramou o Christianos et eos parat perdere, pro seu sangue? Ó corações mais duros que quibus servandis mortuus est Christus, diamantes! Há harmonia em negócios tão

\footnotetext{
101 "non est Iudaeus neque Graecus, non est servus neque liber, non est masculus et femina; omnes enim vos unus estis in Christo Iesu" (Ad Galatas 3,28).

102 "Instaurare omnia in Christo" (Ad Ephesios 1,10).

103 Cf. Isócrates, Panegírico, 21. 11. 12-16. Erasmo compôs o adágio 2494 "Scytharum solitudo" (LB, II, 849 BC). Na epístola 809 (5 de abril de 1518), mencionou a solitudo Scytha.
} 
[380] eorum haurire sanguinem, pro variados, e na vida uma tão inexplicável divisão! quibus suum sanguinem fudit Christus? O Se a lei de nascer é a mesma para todos, é a pectora plus quam adamantina, in rebus mesma para todos a necessidade de envelhecer e tam multis consortium est et in vita tam morrer. Todos têm o mesmo antepassado da inexplicabile dissidium. Eadem nascendi lex omnibus, eadem senescendi moriendique necessitas. Eumdem generis Principem habent omnes, eumdem religionis auctorem, eodem omnes redempti sanguine, iisdem omnes initiati sacris, iisdem [385] aluntur sacramentis. Quicquid ex his redit muneris, ab eodem proficiscitur fonte et ex aequo commune est omnibus. Eadem omnium Ecclesia, denique praemium idem omnium. Quin caelestis illa Hierusalem, ad quam suspirant vere Christiani, a pacis visione nomen habet, cuius interim ecclesia typum sustinet. Et qui fit, ut haec tantopere discrepet ab exemplari? Adeo nihil promovit tot [390] viis solers natura, nihil ipse Christus perfecit tot praeceptis, tot mysteriis, tot symbolis? Vel ipsa mala conciliant et malos, iuxta proverbium; Christianos inter se nec bona nec mala ulla conciliant. Quid humana vita fragilius, quid brevius? Quot ea morbis, quot casibus obnoxia. Et tamen cum plus habeat ex sese malorum, quam ut ferri espécie, todos têm o mesmo mestre de religião, todos foram redimidos com o mesmo sangue, todos foram iniciados nos mesmos ritos, todos são alimentados com os mesmos sacramentos e, quaisquer que sejam os benefícios que destes procedem, são obtidos da mesma fonte e por direito são comuns a todos. Todos têm a mesma Igreja, e, no fim, o prêmio será igual para todos. Mais ainda: aquela Jerusalém Celeste, pela qual os cristãos verdadeiros suspiram, possui o nome de "visão da paz", e, durante esta vida terrena, a Igreja se apresenta como uma figura sua. $\mathrm{O}$ que se passou para que esta se discrepe de tal maneira do modelo? Até que ponto eles nada conseguem, nem a natureza tão industriosa por tantos caminhos, nem o póprio Cristo com tantos preceitos, tantos mistérios, tantos símbolos? Segundo o provérbio, até as maldades unem os maus; ${ }^{104}$ só para os cristãos é que não há coisas boas nem más capazes de uni-los uns aos outros. O que pode haver de mais frágil do que a vida humana? O que há de mais breve? A quantas doenças e acidentes fatais se expõe? E, no entanto, ainda que, por sua natureza, já tenha uma cota de males mais pesada do que se pode

\footnotetext{
${ }^{104} \mathrm{O}$ provérbio citado por Erasmo seria de sua própria autoria conciliant homines mala (Erasmo. Adagia. 1071), mas tem origem aristotélica: "o criminoso se une ao criminoso por prazer" (Aristóteles. Retórica. I e Ética a Eudemo. 1238a e 1239b).
} 
possit, tamen maximam malorum partem ipsi sibi accersunt [395] dementes. Tanta caecitas humanos animos occupat, ut nihil horum perspiciant, sic praecipites aguntur, ut omnia naturae Christique vincula, omnia foedera rumpant, dissecent, diffringant. Pugnant passim atque assidue, nec modus nec finis. Colliditur gens cum gente, civitas cum civitate, factio cum factione, princeps cum principe, et ob duorum homuncionum, qui mox velut ephemera sint [400] interituri, seu stulticiam, seu ambitionem res humanae sursum deorsum miscentur.

[402] Missas faciam veterum bellorum tragoedias. Repetamus decem ab hinc annis acta: ubi non gentium crudelissime pugnatum est terra marique? Quae regio non Christiano sanguine commaduit? Quod flumen, quod mare non humano [405] cruore tinctum est? . Et, o pudor, pugnant immanius, quam Iudaei, quam ethnici, quam ferae. os homens que se faz a guerra. Os judeus, Quicquid bellorum Iudaeis gestum est porém, se faziam guerra, era porque uma ordem

suportar, mesmo assim os homens, dementes, produzem para si mesmos a maior parte dos males. A cegueira das mentes humanas é tão grande que não percebem nada. Agem de modo tão precipitado que rompem, rasgam e infrinjem todos os vínculos da natureza e de Cristo, esquecendo todas as alianças. Combatem assiduamente e em toda parte, a ponto de tumultuar sem medida nem fim. Um povo combate outro povo, uma cidade com outra cidade, uma facção com outra facção, um príncipe com outro príncipe, e, por causa da burrice ou da ambição de dois homenzinhos que hão de perecer como coisas efêmeras, subvertem-se de cima a baixo as coisas humanas.

Não contarei as tragédias das guerras antigas. Contemos somente as dos últimos dez anos. ${ }^{105}$ Onde não encontraremos a crudelíssima luta das nações, por terra e mar? Que região não derramou sangue cristão? Que rio e que mar não estão tingidos com sangue humano? ${ }^{106}$ Ó vergonha! lutam de modo mais feroz do que os judeus, do que os pagãos e do que as feras. Todas as guerras que os judeus moveram contra

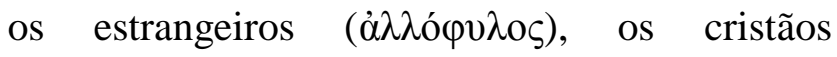
deveriam direcionar contra os vícios; mas, com estes, os homens encontram-se de bem; é contra porem, se faziam guerra, era porque uma ordem

\footnotetext{
105 Erasmo poderia estar se referindo à guerra franco-espanhola. A batalha de Cerignoles e a de Garigliano, por exemplo, datam respectivamente de 28/04 e 27/12 de 1503 .

${ }^{106}$ Herding (1978, p. 79, nota 404) percebe a recepção de Horácio (Carm. II, I, 29-36).
} 
adversus Allophylos ( $\dot{\lambda} \lambda \hat{\lambda} \operatorname{\varphi v} \lambda \circ \varsigma$ ), id divina os levava à batalha. Os cristãos, se Christianis gerendum adversus vitia, deixarmos de lado os pretextos e pensarmos as quibus nunc cum vitiis convenit, cum coisas com retidão, a ambição é que os empurra hominibus bellum est. Et tamen Iudaeos para o mal; a ira, o pior dos conselheiros, age; divina iussio ducebat ad pugnam. arrasta-os o desejo insaciável de possuir. No Christianos, si praetextibus detractis rem mais, aqueles em geral tinham litígios com os vere aestimes, transversos rapit ambitio, estrangeiros, enquanto que os cristãos fazem agit ira [410] pessimus consultor, aliança com os turcos e guerra entre eles pertrahit habendi numquam satiata mesmos. Já os tiranos pagãos, sede de glória era cupiditas. Atque his fere cum exteris res o que em geral os estimulava à guerra, e, seja erat, Christianis cum Turcis foedus est, como for, subjugavam assim nações bárbaras e inter ipsos bellum. Iam ethnicos tyrannos fere gloriae sitis ad bellum exstimulabat; atque hi tamen sic barbaras atque efferas nationes subigebant, ut vinci expediret, et victor de victis bene mereri studeret. Dabant operam, ut quam fieri posset, incruenta esset victoria, [415] quo simul et victori honesta fama praemium esset et victis solatium victoris benignitas.

[417] At pudet meminisse, quam pudendis, quam frivolis de causis Mas envergonha lembrar quão vergonhosos e quão frívolos são os motivos Christiani Principes orbem ad arma pelos quais os príncipes cristãos levam o mundo concitent. Hic obsoletum ac putrem às armas. ${ }^{108}$ Este ou encontra ou inventa algum aliquem titulum aut reperit aut título qualquer, obsoleto ou esquecido, como se commentus est, quasi vero ita magni realmente importasse muito quem é que referat, quis regnum administret, [420] administra o reino, desde que vele inteiramente modo publicis commodis reste pelos interesses públicos. Aquele alega não sei consulatur. Ille causatur omissum nescio que cláusula foi omitida em um contrato de cem

\footnotetext{
${ }^{107}$ Segundo Margolin (1992, p. 931), Erasmo se refere a um tratado de paz entre o sultão e Veneza datado de 1503, renovado em 1514, e em setembro de 1517.

${ }^{108}$ Cf. Horácio, Carm. I, 35, 15.
} 
quid in foedere centum capitum. Hic illi privatim infensus est ob sponsam interceptam aut scomma liberius dictum. Et quod est omnium sceleratissimum, sunt qui tyrannica arte, quod populi concordia potestatem suam labefactari sentiant, dissidio stabiliri, subornent qui data opera bellum excitent, quo simul et coniunctos dirimant et infelicem populum licentius expilent, scelestissimi quidam, qui populi malis aluntur et quibus pacis tempore non multum est quod agant in republica. Quae tartarea furia venenum hoc in pectus Christianum potuit immittere? Quis hanc tyrannidem docuit Christicolas, quam nec Dionysius ullus nec Mezentius ullus novit? Belluae verius quam homines, et sola tyrannide nobiles [430] nec usquam cordati nisi ad nocendum nec umquam concordes, nisi ad opprimendam rempublicam. Et haec qui gerunt, pro Christianis habentur, audent humano sanguine undique polluti ad sacras aedes, ad sacras aras accedere? O pestes in extremas insulas deportandas. flagelos! Que sejam deportados para as ilhas capítulos. Este é inimigo pessoal daquele, por causa de uma esposa que não lhe foi entregue, ou por algum sarcasmo mais licencioso. E o que é mais criminoso de tudo é que há aqueles que, por meio de uma artimanha tirânica, porque os povos em concórdia arruinam sua autoridade, enquanto que as divisões a solidificam, subornam outros para que excitem a guerra, a fim de que, ao mesmo tempo e em acordo mútuo, possam desunir e pilhar mais livremente o povo infeliz. Isso é o que procuram os príncipes mais criminosos, que se alimentam com males do povo e que, em tempo de paz, não há muito que façam por suas repúblicas. Que fúria infernal foi capaz de infundir este veneno nos peitos cristãos? Quem ensinou aos seguidores de Cristo essa tirania, que nem Dionísio, ${ }^{109}$ nem Mezêncio $^{110}$ conheceram jamais? São verdadeiramente mais feras do que homens, nobres somente pela tirania, sagazes apenas para matar, e concordes apenas para oprimir a república. E os dessa laia são tidos por cristãos e, contaminados por sangue humano, ousam aproximar-se dos edifícios e altares sagrados. Ó

\footnotetext{
109 Erasmo não se refere ao Deus do Vinho, mas aos reis de Siracusa, Dionísio I, o Antigo, (430-367 a. C.), tirano de Siracusa por trinta e oito anos até a sua morte. Segundo Deodoro Sículo (90-30 a. C.), Dionísio era de origem humilde, mas tomou conta do poder por ocasião da guerra de Cartago em 405 a. C. Após lutas e alianças militares, foi derrotado pelos cartagineses em 383 a. C. (Cf. Diodoro Sículo, História, XIII, 96, 4).

${ }^{110}$ Mezêncio foi um rei de origem etrusca que governou a cidade de Cere. Destacado personagem da Eneida de Virgílio (70-19 a. C.) toma parte da guerra contra os troianos. Virgílio, em discordância com os autores mais antigos, transmitiu a figura de Mezêncio como um terrível tirano. Narra que entre outras torturas hediondas, Mezêncio permitia que seus prisioneiros fossem amarrados face a face com outros criminosos vivos ou mortos, os quais teriam cometido tantos excessos que os próprios habitantes de Cere o expulsaram (Virgílio, Eneida, XI, 7-16). Catão registrou a prepotência do tirano Mezêncio ao exigir para si as primícias do vinho destinadas a Júpiter(Origines, I, 12).
} 
Si Christiani corporis unius membra sunt, cur non gratulatur quisque alienae felicitati? Nunc prope iusta movendi [435] belli causa videtur regnum finitimum rebus omnibus paulo florentius.

[436] Etenim si verum fateri volumus, quid aliud commovit et hodie commovet tam multos ad armis lacessendum Franciae regnum, nisi quod est unum omnium florentissimum? Nullum latius patet, nusquam senatus augustior, nusquam academia celebrior, nusquam concordia maior et ob hoc ipsum potestas summa.

[440] Nusquam aeque florent leges, nusquam illibatior religio nec Iudaeorum commercio corrupta, velut apud Italos, nec Turcarum aut Maranorum vicinia infecta quemadmodum apud Hispanos et Hungaros. Germania, ne quid dicam de Bohoemis, in tot regulos dissecta est ac regni ne species quidem ulla. Sola Francia ceu flos illibatus Christianae ditionis et velut arx quaedam tutissima, si qua fors [445] tempestas ingruat, tot modis impetitur, tot artibus incessitur, nec ob aliud, nisi cuius gratia conveniebat gratulari, si qua vena Christianae mentis mais remotas! Se são membros de um só corpo cristão, por que cada um não se congratula com a felicidade alheia? Hoje em dia, quase parece que é uma justa causa para mover a guerra que o reino vizinho seja um pouco mais florescente em todas os aspectos.

$\mathrm{E}$, de fato, se queremos reconhecer a verdade, que outra coisa impeliu, e impele hoje em dia, tantos povos às armas contra o Reino da França, senão o fato de este ser o mais próspero de todos? Nenhum é tão grande; em nenhum lugar o senado é mais respeitável; em nenhum lugar a universidade é mais célebre; em nenhum país a concórdia é maior, e, por isso mesmo, o poder tão supremo. ${ }^{111}$

Em nenhum lugar as leis florescem como ali; em nenhum lugar a religião é mais pura, já que não está corrompida pelo comércio com os judeus, como entre os italianos, nem as fronteiras estão repletas de turcos e marranos, como entre os espanhóis e os húngaros. A Alemanha, para não mencionar os Boêmios, foi dividida em pedaços por tantos reizinhos e não tem sequer a aparência de um reino. Só a França é como uma flor intacta da cristandade, como sua mais segura cidadela; mas, se por acaso surge alguma tempestade, ela é de tantos modos atacada, é combatida com tantas artes, pelo único motivo pelo qual deveria ser celebrada, se nos seus inimigos houvesse um pouco de espírito cristão.

\footnotetext{
${ }^{111}$ Segundo Margolin (1992, p. 933), "Erasmo idealiza a ambição do imperialismo francês por motivações de ordem política, sobretudo, pela francofilia da política borgonhesa".
} 
esset in istis. Atque his tam impiis factis praetexitur titulus pius: sic sternunt viam ad propagandum imperium Christi. O rem monstrosam! parum consultum putant reipublicae Christianae, nisi pulcerrimam ac felicissimam ditionis christianae partem [450] subverterint.

[451] Quid quod in his tractandis feras etiam ipsas feritate praecedunt? Non omnes pugnant belluae, nec ferarum, nisi in diversum genus conflictatio est, quemadmodum et ante diximus, saepius inculcandum, quo magis inhaereat animis. Vipera non mordet viperam, nec lynx lyncem discerpit. Ac rursum illae cum [455] pugnant, suis pugnant armis. Illas armavit natura. Homines inermes natos, o Deum immortalem, qualibus armis armat ira. Tartareis machinis impetunt Christiani Christianos. Quis enim credat bombardas hominis inventum esse? Nec ille tam densis agminibus in mutuum exitium ruunt. Quis unquam vidit decem leones cum decem tauris congredi? At quoties viginti millia Christianorum cum [460] totidem Christianis ferro decertant. Tanti est laedere, tanti est haurire sanguinem fratrum. Nec illis fere bellum est, nisi cum fames, aut cura sobolis in rabiem agit. At Christianis quae tam levis iniuria est, ut non videatur idonea bellandi
E estes atos tão perversos são justificados por alegações tão pias! É assim que se abre o caminho para propagar o império de Cristo! Ó ato monstruoso! Acham que cuidam pouco dos interesses da república cristã, a não ser que ponham a perder a parte mais bela e mais fértil da cristandade!

Que nos resta dizer senão que os homens, com esses seus empreendimentos, superam em selvageria as próprias feras? Nem todos os animais selvagens são agressivos, e, aqueles que são ferozes, o são apenas contra espécies diferentes, como já dissemos anteriormente e convém repetir várias vezes para inculcá-lo e fixá-lo nas mentes. A víbora não morde a víbora, e lince não devora o lince. E repito: quando lutam, lutam com as suas armas, aquelas com que a natureza os armou; mas aos homens, que nasceram desarmados, ó Deus imortal, com que armas a ira os arma. Cristãos atacam cristãos com máquinas infernais. Quem acreditaria que o canhão é uma invenção do homem? Tampouco aquelas, buscando destruição mútua, se atiram umas contra as outras em fileiras cerradas. $\mathrm{Ou}$ alguém já viu dez leões formados em pelotão contra dez touros? Mas quantas vezes vinte mil cristãos desembainharam a espada contra outros tantos cristãos? Tão importante é ferir e derramar o sangue dos irmãos. E mais: as feras impelem ao furor, a não ser quando há fome ou por cuidado da prole. Para os cristãos, contudo, quase não existe uma injúria, por mais leve que 
occasio? Si faceret ista plebes, utcumque praetexi poterat inscitia; si iuvenes, excusari poterat aetatis imperitia, si prophani, nonnihil elevaret atrocitatem facti [465] personae qualitas. Nunc ab iis potissimum videmus oriri bellorum semina, quorum consilio moderationeque populi motus componi conveniebat. Contentum illud et ignobile vulgus condit egregias urbes, conditas civiliter administrat, administrando locupletat. In has irrepunt satrapae et ceu fuci, quod aliena partum est industria, surripiunt et quod a plurimis bene congestum est, a paucis [470] male dissipatur: quod recte conditum, crudelissime diruitur. Quod si prisca non meminerunt, repetat qui volet secum hisce duodecim annis gesta bella. Causas expendat, comperiet omnia principum gratia suscepta, magno populi malo gesta, cum ne tantillum quidem ad populum attineret.

[474] Iam quod olim foedum habebatur apud ethnicos, caniciem galea premere, ut [475] inquit ille, id apud Christianos laudi ducitur. Turpe senex seja, que não lhes pareça ocasião para guerrear. Se fosse a plebe a fazer isso, poder-se-ia de uma forma ou de outra pretender ignorância. Se os jovens, podia excusá-los a imperícia da idade. Se os leigos, a condição da pessoa em certa medida relevaria a atrocidade do feito. Mas hoje vemos que as sementes da guerra são lançadas exatamente por aqueles cujo conselho e moderação conviria que as agitações fossem contidas. Aquele vulgo ignóbil, desprezado e sem nobreza, edifica cidades egrégias; uma vez edificadas, administra-as civilizadamente; e, ao administrá-las, as enriquece. Irrompem nelas os sátrapas e, como se fossem zangões, roubam o que é produto do trabalho alheio, e o que foi poupado por muitos é dissipado por poucos, e o que havia sido construído retamente é destruído com crueldade. A esse respeito, se não há recordação dos tempos antigos, que aquele que o desejar repasse consigo mesmo a memória das guerras feitas nos últimos dozes anos, pondere suas causas e descobrirá que todas se deram por culpa dos príncipes, realizadas para grande prejuízo do povo, uma vez que suas motivações nem um tantinho sequer se aproveitassem ao povo.

Até aquilo que outrora era consenso entre os pagãos, de que não se devia cobrir os cabelos brancos com um elmo, como diz o poeta, ${ }^{112}$ esse costume hoje, entre os cristãos, tornou-se motivo

\footnotetext{
${ }^{112}$ Cf. Virgílio. Aeneida. IX, 612; Ovídio. Trist. IV, 1, 74.
} 
miles Nasoni et istis magnifica res est bellator septuagenarius. Imo ne sacerdotes quidem ipsos pudet, quos olim deus nec in sanguinaria illa et inclementi lege Moysi voluit ullo sanguine pollui: non pudet theologos Christianae vitae magistros, non pudet absolutae religionis professores, non pudet episcopos, non pudet cardinales et [480] Christi vicarios eius rei auctores ac faces esse, quam Christus tantopere detestatus est. Qui convenit mitrae et galeae? Quid pedo cum gladio? Quid evangelico codici cum clypeo? Qui convenit pacis omine salutare populum et orbem ad turbulentissimas pugnas concitare, pacem dare lingua, re bellum immittere? Tun eodem ore quo Christum pacificum praedicas, bellum laudas, eademque [485] tuba Deum canis et Satanam? Tun apud concionem sacram cuculla tectus ad caedem incitas simplicem populum, qui ex ore tuo doctrinam exspectabat evangelicam? Tun apostolorum occupans locum pugnantia doces cum apostolorum praeceptis? An non vereris, ne quod de Christi praeconibus dictum est; Quam speciosi pedes nunciantium pacem, nunciantium bona, nunciantium salutem in diversum [490] vertatur; Quam foeda lingua sacerdotum adhortantium ad de louvor. Para Nasão, é coisa infame um soldado velho, enquanto, para estes, ser um guerreiro septuagenário é algo magnífico! Ademais, nem os próprios sacerdotes se envergonham, justamente eles, aos quais outrora Deus não permitiu nenhuma contaminação pelo sangue, nem naquela sanguinária e inclemente lei de Moisés $^{113}$; não se envergonham os teólogos, mestres da vida cristã; não se envergonham os professores de uma religião perfeita; não se envergonham os bispos; não se envergonham os cardeais e os vigários de Cristo de serem os autores e incitadores de algo que Cristo detestou tanto. Que relação existe entre a mitra e o elmo? Entre a docência e a espada? Entre Evangelho e o escudo? Que relação há entre saudar o povo com o sinal da paz e incitar o mundo a lutas turbulentíssimas? Desejar a paz com a língua, mas na realidade provocar a guerra? É possível que pregues o Cristo pacífico com a mesma boca com que louvas a guerra e que cantes Deus e Satanás com o mesmo instrumento? É possível que, coberto com o capuz do hábito, incites no sagrado púlpito o povo simples, que esperava da tua boca a doutrina evangélica, ao assassinato? É possível que tu, ocupando o lugar dos Apóstolos, ensines a violência, em contradição com os preceitos dos Apóstolos? Acaso não temes aquilo que é dito sobre os arautos de Cristo: "como são belos os pés dos que anunciam a paz, dos que anunciam o

${ }^{113}$ Erasmo provavelmente se refere às leis do Pentateuco que se assemelham à Lei de Talião. 
bellum, incitantium ad mala, bem, dos que anunciam a salvação", ${ }^{114}$ se mude provocantium ad perniciem? Apud em seu contrário: "como é destestável a língua Romanos adhuc impie pios, qui dos sacerdotes que exortam à guerra, que incitam pontificium maximum iniret, ex more ao mal, que provocam a agressão"? Entre os confirmabat iureiurando, se manus ab romanos, até então impiamente pios, aquele que omni sanguine puras servaturum, adeo ut tomava posse como pontífice máximo era ne laesus quidam ulcisceretur. Atque obrigado por juramento a conservar suas mãos huius sacramenti fidem constanter limpas de todo sangue, de tal forma que, mesmo praestitit Titus Vespasianus, imperator que fosse ferido por alguém, não se vingaria. ethnicus, [495] idque laudi datur a Tito Vespasiano, ${ }^{115}$ imperador pagão, manteve a scriptore ethnico. At, o prorsus sublatam fidelidade a este sacramento com zelo fiel, e por e rebus humanis frontem, apud isso foi louvado por um escritor pagão. ${ }^{116}$ Entre Christianos Deo dicati Sacerdotes, et qui os cristãos, porém, ó vergonha inteiramente his quoque sanctius aliquid prae se ferunt removida das ações humanas! Os sacerdotes monachi ad caedes, ad strages cristãos, consagrados a Deus, e os monges, que inflammant et Evangelii tubam Martis tubam faciunt, obliti dignitatis suae sursum ac deorsum cursitant, nihil non tum faciunt, tum patiuntur, dum bellum excitent: et per hos Principes [500] alioqui fortassis quieturi, ad pugnam se gabam de superar aqueles em santidade, inflamam os ânimos dos príncipes e da plebe aos assassinatos e ao massacre. Transformam o clarim do Evangelho em trombeta de Marte, e, esquecidos de sua dignidade, correm para cima e para baixo, tudo fazendo e tudo suportando até inflammantur, quorum auctoritate que consigam incitar à guerra; e por causa desses tumultuantes sedari conveniebat. Imo, príncipes que são inflamados à luta, sem sua quod est prodigiosius, belligerantur ipsi intervenção, talvez se inclinassem para a paz, idque earum rerum gratia, quas et apud precisamente deles, a quem convinha acalmar impios contempsere philosophi, com sua autoridade. E até, o que é ainda mais

\footnotetext{
114 "Quam pulchri super montes pedes annuntiantis, praedicantis pacem, annuntiantis bonum, praedicantis salutem" (Isaiah 52,1).

115 Tito Vespasiano, imperador romano entre 79 e 81 d. C., fez um juramento de guardar suas mãos puras da efusão de sangue humano. Com a pacificação das revoltas judaicas, culminada com a destruição de Jerusalém (70 d. C.), obteve durante seu governo grande popularidade ao assumir o Império a ponto de ser louvado pelo historiador Suetônio e outros historiadores contemporâneos especialmente pela benignidade para com as vítimas da erupção do Vesúvio em 79 d. C. e o incêndio de Roma em 80 d. C.

${ }^{116}$ Erasmo se refere às palavras de Suetônio (As vidas dos doze césares, Vida de Tito. 9,1).
} 
quarumque contemptus proprius ac peculiaris est viris apostolicis.

[504] Ante paucos annos, cum fatali quodam morbo mundus ad arma raperetur, [505] evangelici praecones, hoc est, Minores ac Praedicatores $e$ suggesto sacro classicum canebant et ultro ad furiam propensos magis accendebant. Apud Britannos animabant in Gallos, apud Gallos animabant in Britannos, omnes ad bellum instigabant. Ad pacem nemo provocabat praeter unum aut alterum, quibus pene capitale fuit me vel nominasse. Cursitabant ultro citroque sacrosancti praesules [510] et dignitatis et professionis suae obliti publicum orbis morbum opera sua exacerbantes tum hinc Iulium pontificem Romanum, hinc Reges ad maturandum bellum instigantes, perinde quasi non satis ipsi sua sponte insanirent; et tamen hanc manifestariam insaniam magnificis titulis praeteximus. Huc patrum leges, huc piorum hominum scripta, huc arcanae scripturae verba prodigioso: eles mesmos guerreiam por causa de coisas que até entre pagãos os filósofos votaram ao desprezo, os quais devem ser objeto do desprezo mais rpórpio e peculiar dos varões apostólicos.

Há alguns anos, quando certa febre fatal fez com que o mundo inteiro acorresse às armas, os pregadores evangélicos, isto é, alguns minoritas e dominicanos, cantavam o clássico toque de guerra do alto do púlpito sagrado ${ }^{117} \mathrm{e}$ acendiam ainda mais aqueles já propensos à fúria. Entre os ingleses, inflamavam contra os franceses; entre os franceses, inflamavam contra os ingleses. Instigavam todos à guerra. À paz, ninguém incitava, a não ser um ou outro que pouco faltou para que fossem condenados à pena capital por terem mencionado meu nome. Os santíssimos prelados corriam de um lado para o outro e, esquecidos de sua dignidade e de sua profissão, exarcebavam com seus atos a miséria do mundo; instigando ora, de um lado, o próprio Júlio, ${ }^{118}$ Pontífice Romano, ora, do outro, esses tantos reis a preparar a guerra, como se eles, por si mesmos e por sua própria vontade, já não estivessem suficientemente loucos. Mas adornamos esta loucura manifesta com títulos pomposos. Com essa finalidade deturpamos de

117 Suggestus sacro era um lugar alto ou tribuna, no qual os oradores romanos falavam ao povo. Cf. Erasmo. Dulce bellum. LB, II $956 \mathrm{~F}$.

118 O papa Júlio II (1443- 1513) foi conhecido como Il Papa Terribile ou Il Papa Guerriero. Chamavase Giuliano della Rovere e foi Papa entre 1503 e 1513. Seu papado foi marcado por atividades políticas, projetos arquitetônicos e cultivo das artes. Entre 1509 e 1513, inclsuive com a convocação de um concílio em Latrão, deu apoio à Liga Santa ou Liga de Cambrai com Luís XII da França, Maximiliano I, Imperador Alemão, Fernando II, Rei de Aragão e Henrique VIII, da Inglaterra, contra a República de Veneza a fim de conquistar a Romagna. 
impudentissime [515] detorquemus, ne dicam impie. Imo iam eo prope rediit res, ut stultum et impium sit adversus bellum hiscere et id laudare, quod sole ore Christi laudatum est. Parum consulere populo, parum favere Principi videtur, qui suaserit rem omnium saluberrimam et ab omnium pestilentissima dehortetur. Iam ipsa castra sequuntur sacrifici, praesunt in castris episcopi et relictis ecclesiis suis [520] Bellonae rem agunt. Imo gignit iam bellum sacerdotes, gignit episcopos, gignit cardinales, quibus campi legatus honorificus titulus et apostolorum successoribus dignus habetur. Quo minus mirum, si Martem spirant, quos Mars genuit. Et quo malum sit insanabilius, tantam impietatem pietatis specie praetexunt. Vexilla crucem habent. Miles impius, et nummis aliquot ad lanienam ac caedem [525] conductus crucis insigne praefert, et belli symbolum est, quod solum dedocere bellum poterat. Quid tibi cum cruce, scelerate miles? Istis animis, istis factis, dracones, tigrides ac lupi conveniebant. Istud signum eius est, qui non pugnando, sed moriendo vicit, forma desavergonhada, para não dizer ímpia, as leis dos nossos antepassados, ${ }^{119}$ os escritos dos homens piedosos e as palavras da Sagrada Escritura. E mais: chegou-se ao ponto em que ser contra a guerra e louvar aquilo que Cristo valorizou e louvou acima de tudo é considerado prova de loucura e de impiedade. Parece que aquele que aconselhar a mais salutar e dissuadir da mais pestilenta de todas as coisas, este zela pouco pelos interesses do povo e favorece pouco ao príncipe. Os sacerdotes acompanham os locais da guerra, os bispos tomam a frente nos acampamentos militares, e, abandonadas suas igrejas, fazem sacrifícios a Belona. ${ }^{120} \mathrm{E}$ já se chegou ao ponto de a guerra gerar sacerdotes, gerar bispos, gerar Cardeais, em relação aos quais se considera digno dos sucessores dos apóstolos e sumamente honorífico o título de embaixador da guerra. Não é de se admirar: aqueles a quem Marte gerou, respiram Marte. E, para que o mal seja mais incurável, revestem tão grande impiedade com aparência de piedade. Os estandartes ostentam a cruz. ${ }^{121} \mathrm{O}$ soldado ímpio, contratado por algumas moedas para esquartejar e matar, porta diante de si o símbolo da cruz, e torna-se estandarte de guerra a única coisa que poderia dissuadir da guerra. $\mathrm{O}$ que tu, soldado

\footnotetext{
119 A expressão tem um sentido duplo: primeiro, pode-se referir aos Padres da Igreja, ou seja, aqueles padres antigos que na História da Igreja, que se tornaram célebres, segundo a Tradição católica, pela vida virtuosa, ortodoxia e antiguidade (viveram entre os séculos I e VIII d. C.); e segundo, aos Patriarcas hebreus, cujas histórias se encontram no livro do Gênesis.

${ }^{120}$ Bellona foi uma antiga deusa romana da Guerra correspondente à deusa grega Enyo.

${ }^{121}$ O papa Júlio II havia dado o estandarte da cruz aos suíços em recompensa dos serviços prestados à Santa Sé.
} 
qui servavit, non perdidit, quodque cum primis admonere te poterat, cum quibus hostibus tibi res sit, si modo Christianus es, et qua [530] ratione vincendum sit. Tu salutis insigne gestas ad fratris perniciem properans, et cruce perdis eum, qui cruce servatus est? Quid quod ab arcanis illis et adorandis sacris, nam haec quoque pertrahuntur in castra, in quibus inprimis summa Christianorum concordia repraesentatur, curritur in aciem, dirum ferrum in fratris viscera stringitur et facinoris omnium sceleratissimi, quo non aliud esse [535] potest impiis spiritibus gratius, Christum faciunt spectatorem, si tamen illic dignatur adesse Christus. Denique quod est omnium absurdissimum, in utrisque castris, in utraque acie crucis signum relucet, in utrisque sacra. Quid hoc monstri est: pugnat crux cum cruce, Christus adversus Christum belligeratur. Hoc signum Christiani nominis hostes terrere solet. Cur nunc oppugnant, quod adorant? [540] Homines non una digni cruce, sed vera. Quaeso, quid in hisce sacris orat miles pater noster? Os durum, audes eum appellare patrem, qui fratris tui iugulum petis? Sanctificetur nomen tuum: qui magis dehonestari poterat nomen dei, quam istiusmodi inter vos tumultibus? Adveniat regnum tuum: sic oras, qui tanto celerado, fazes com a cruz? Esse modo de pensar e de agir convém mais a serpentes, tigres e lobos. Esta insígnia é daquele que não venceu ao lutar, mas ao morrer; que salvou, não fez perecer. Ele veio te ensinar, se és cristão, contra que inimigos tu deverias lutar e como deverias fazer para vencer. Tu portas contigo o emblema da salvação e, ao mesmo tempo, te precipitas ao assassinato do teu irmão, e destróis com a cruz aquele que foi salvo pela cruz? E que dizer dos sacramentos misteriosos e solenes? É fato que eles também levam para os acampamentos militares aquelas cerimônias nas quais se representa sobretudo a suma concórdia dos cristãos. Corre-se para a linha de batalha e, com cruéis espadas, rasgamse as vísceras do irmão. Isso obriga Cristo a se tornar espectador do mais celerado de todos os crimes - que é, ao mesmo tempo, o mais grato aos espíritos mais ímpios -, se é que Cristo consente em estar presente num acampamento. Por fim, o mais absurdo de tudo é que em ambos os acampamentos e em ambas linhas de batalha se ergue e brilha o sinal da cruz, e em ambos os ritos sagrados são celebrados. Pode haver algo mais monstruoso? A cruz luta contra a cruz e Cristo guerreia contra Cristo? Este sinal costuma aterrorizar os inimigos do nome cristão. Por que os cristãos atacam aquilo que adoram? Os homens não são dignos de somente portar o símbolo da cruz, mas sim uma cruz verdadeira. Por favor, por que, durante a missa, o soldado recita o Pai Nosso? Como te atreves, boca 
sanguine tyrannidem tuam moliris? Fiat voluntas tua, quemadmodum in coelo, ita [545] et in terra: pacem vult ille, et tu bellum paras. Panem quotidianum a communi Patre petis, qui fraternas exuris segetes et tibi quoque mavis perire, quam illi prodesse? Iam quonam ore dices illud: et dimitte nobis debita nostra, sicut et nos dimittimus debitoribus nostris, qui ad parricidium festinas? Deprecaris periculum tentationis, qui tuo periculo fratrem in periculum pertrahis. A malo liberari postulas, [550] cuius instinctu summum malum fratri machinaris?

[551] Plato negat appellandum bellum, quod Graeci moveant adversus Graecos. Seditio est, inquit. Et istis sanctum etiam bellum est, quod ob quamlibet causam tali milite, talibus armis cum Christiano gerit Christianus? Ethnicorum leges, culeo insutum in profluentem abiiciunt, qui ferrum fraterno desavergonhada, a chamar de Pai àquele a quem pedes auxílio para cortares a garganta do teu irmão? "Santificado seja o teu nome": o que poderia macular de forma mais completa o nome de Deus senão esse tipo de disputa entre vós? "Venha a nós o vosso reino": fazes este pedido, tu que, com tão grande derramamento de sangue, te empenhas em tua tirania? "Seja feita a vossa vontade assim na terra como no céu": Cristo quer a paz e tu preparas guerra? "O pão de cada dia" pedes ao Pai comum, tu que queimas as plantações do teu irmão e preferes morrer a beneficiar o próximo? Pois como é possível que rezeis aquilo? "E perdoai as nossas dívidas, assim como nós perdoamos os nossos devedores", tu que te apressas para o fratricídio? Oras que Ele te proteja no "perigo da tentação", tu que, com perigo para ti mesmo, conduzes o teu irmão para o perigo? Tu pedes para seres livrado do mal e, instigado por ele, maquinas contra teu irmão o pior dos males?

Ao ver gregos moverem guerra contra outros gregos, Platão afirmou que não se deve chamar essa luta de "guerra", denominando-a antes "sedição"122. Enquanto para os cristãos é "santa" a guerra em que, com tal tipo de soldados e com tais armas, uns cristãos brandem armas contra outros cristãos por qualquer pretexto insignificante. Segundo as leis dos pagãos, quem manchasse sua espada com sangue

\footnotetext{
${ }^{122}$ Cf. Platão. República. V, 470.
} 
sanguine imbuerit. [555] An minus fraterno deveria ser fechado em um saco e fratres sunt, quos Christus copulavit, jogado no rio da cidade ${ }^{123}$. Serão menos irmãos quam quos sanguinis propinquitas? Et aqueles que Cristo uniu do que aqueles unidos tamen hic praemium est parricidio. O pela consanguinidade? E, contudo, entre vós dámiseram bellantium sortem! Qui vincit, se prêmio ao fratricídio. Ó triste sorte dos parricida est, qui vincitur, perit, nihilo beligerantes! Quem vence é fratricida, mas quem secius parricidio obnoxius, quod é vencido, morre, igualmente culpado de parricidium conatus est. Et post haec fratricídio, pois tentou praticá-lo. Além disso, os exsecrantur Turcas velut impios et a turcos são execrados como ímpios e alheios a Christo alienos, quasi vero cum haec Cristo, como se, na verdade, fossem cristãos agunt, ipsi Christiani sint, aut quasi aqueles que agem desse modo e se proclamam Turcis [560] ullum spectaculum exhiberi cristãos, ou como se houvesse um espetáculo possit iucundius, quam si conspiciant mais agradável aos turcos do que verem os illos mutuis telis sese confodientes. cristãos se ferirem uns aos outros com lanças. Os Immolant, ut aiunt, Turcae daemonibus. cristãos dizem que os turcos oferecem imolações At cum his nulla victima sit acceptior, aos demônios, mas como, para esses, nenhuma quam si Christianus mactet Christianum, oferenda sacrificial lhes é mais agradável do que quaeso, quid aliud facis quam illi? Tum um cristão imolado por outro, pergunto: e vós? enim gemina fruuntur hostia spiritus Em que sois diferentes dos turcos? De fato, os impii, cum pariter et qui mactat, et qui mactatur fit victima. Si quis Turcis favet, si quis amicus est [565] daemonibus, hostias huiusmodi frequenter offerat. Sed audio iamdudum, quid excusent homines in suum ipsorum malum ingeniosi. Cogi se queruntur, et invitos ad bellum pertrahi. Detrahe personam istam, abiice fucos, tuum ipsius pectus consule; Estes se queixam de serem constrangidos, reperies iram, ambitionem, stultitiam huc arrastados à guerra a contragosto. Arranca essa

\footnotetext{
${ }^{123}$ A expressão culleo insutus (costurado em um saco) foi recebido no Adágio 3978. Agostinho (Contra Faustum, XXII, 22) já tratava dessa pena imposta aos parricidas ocorrente também em Sêneca (Dial. 3,16,5), Quintiliano (Inst. 7,8,6) e Justiniano (Institutiones, 18,16).
} 
pertraxisse, non necessitatem, nisi forte hac fini necessitatem metiris, si non per omnia satisfiat [570] animo. Ad populum phaleras, deus fucis non deluditur. Atque interea solennes aguntur supplicationes, magnis clamoribus petitur pax, vociferantur immani boatu, ut pacem nobis dones, te rogamus: audi nos. Nonne iure optimo Deus istis responderit: quid me ridetis? Rogatis ut depellam, quod ipsi vobis accersitis volentes. Deprecamini, cuius ipsi vobis estis auctores. Si quaelibet offensa [575] bellum parit, cui tandem non est quod queratur? Inter uxorem et maritum incidunt, ad quae sit connivendum, nisi malis dirimi benevolentiam. Quod si quid eiusmodi sit ortum inter principes, quid opus erat mox ad arma rapi?

[578] Sunt leges, sunt hommes eruditi, sunt venerandi abbates, sunt reverendi episcopi, quorum salubri máscara, joga fora esses disfarces e consulta o teu próprio coração! E encontrarás que foram a ira, a ambição e a loucura que te arrastaram para a guerra, e não a necessidade. A não ser que chames de necessidade aquele insaciável desejo da avareza. Guarda os adornos para o povo, Deus não se ilude com disfarces ${ }^{124}$. E, enquanto isso, realizam-se súplicas solenes, pedem paz com grande clamor, gritam com ruído gigantesco: "rogamos-te que nos dês a paz, nós te suplicamos, ouve-nos!" ${ }^{\prime 25}$. Com todo direito, não poderia Deus responder-lhes: "por que vos rides de mim? Rogais que eu afaste de vós aquilo que vós mesmos procurastes de livre vontade? Suplicais-me que vos livre daquilo de que vós mesmos sois os autores?" Se uma ofensa qualquer provoca uma guerra, quem não teria motivos para se queixar? Entre marido e mulher surgem às vezes alguns conflitos para os quais convém fechar os olhos, a menos que a gravidade dos males impeça a benevolência. Ora, se atritos desse tipo surgirem entre príncipes, por que motivo recorrer sem demora às armas?

Existem leis, existem homens eruditos, existem abades venerandos e existem bispos reverendos, com cujo conselho salutar poder-seia remediar o conflito. Por que não tornar

\footnotetext{
${ }^{124}$ Cf. Pérsio. Sátiras. 3,30.

${ }^{125}$ Erasmo se refere a uma das invocações da Litania Sanctorum, uma antiga oração de formato litânico, cujo texto latino foi estabelecido em 590 pelo Papa Gregório I, o Magno. Sua versão grega é ainda mais antiga e remonta a Gregório Taumaturgo (213-270): "Ut regibus et principibus christianis pacem et veram concordiam donare digneris. Te rogamus, audi nos. Ut cuncto populo christiano pacem et unitatem largiri digneris. Te rogamus, audi nos" (Vauchez, 1994, p. 27).
} 
consilio tumultus rerum componi poterat. árbitros homens que de modo algum possa ser Cur non hos [580] potius arbitros faciunt, tão perversos que não estejam a desertar por um quos haud possint tam iniquos nancisci, mal menor do que experimentar armas? quin minore malo discessuri sint, quam si Dificilmente uma paz é tão iníqua que não seja armis experiantur? Vix ulla tam iniqua preferível à mais justa das guerras. Faz bem os pax, quin bello vel aequissimo sit potior. cálculos de cada artigo que a guerra exige e, por Prius expende singula, quae bellum vel outro lado, acarreta, e terás previsto quanto lucro postulat vel adducit, et quantum lucri te renderá. Suma é a autoridade do Pontífice feceris intelliges. Summa Romani Romano. Entretanto, no momento em que os pontificis auctoritas. Ast cum gentes, cum povos e os príncipes se enfrentam em guerras principes impiis bellis tumultuantur, perversas - e isto por longos anos - onde está a idque annos [585] aliquot, ubi tum autoridade dos pontífices junto às nações? Onde pontificum auctoritas, ubi potestas está o seu poder, próximo ao de Cristo? Era Christo proxima? Hic certe erat nesse ponto que a autoridade papal certamente expromenda, nisi ipsi similibus tenerentur deveria ser exercida, se também os papas não cupiditatibus. Vocat Pontifex ad bellum, paretur. Vocat idem ad pacem, cur non obtemperatur itidem? Si pacem malunt, cur Iulio bellandi auctori tam alacriter obeditum est, Leoni ad pacem et compartilhassem as mesmas ambições. Se o pontífice conclama para a guerra, logo é obedecido. Se ele mesmo apela à paz, por que não se lhe obedece da mesma forma? Se preferem a paz, então por que a ordem para concordiam provocanti vix quisquam guerrear de Júlio ${ }^{126}$ foi obedecida com obtemperat? Si vere sacrosancta est entusiasmo, mas, quando Leão ${ }^{127}$ apelou para a Romani [590] pontificis auctoritas, certe paz e a concórdia, quase ninguém obedeceu? Se maxime valere par est, quoties ad id a autoridade do Pontífice Romano é provocat, quod unice docuit Christus. verdadeiramente sagrada e santa, deveria valer Caeterum quos Iulius ad bellum exitiale de modo certo e absoluto todas as vezes que potuit excitare, cum Leo sanctissimus visasse ao que Cristo quis ensinar de modo

\footnotetext{
${ }^{126}$ Referência ao Papa Júlio II.

${ }^{127}$ Papa Leão X (1475-1521), cujo nome de batismo era Giovanni di Lorenzo de Medici, que sucedeu Júlio II em 11/03/1513 e presidiu a Sé de Pedro, tinha concluído um tratado de paz com os franceses vitoriosos na Batalha de Marignan (Viterbo, 13/10/1515). Margolin (1992, p. 940) informa que "após a guerra de Urbino, o Papa havia defendido uma trégua na Europa em vista de uma eventual cruzada". Erasmo, por diplomacia, mitifica a figura do Papa Leão como conciliador. Os registros históricos, porém, não escusam esse pontífice de atividades e alianças guerreiras.
} 
pontifex non idem possit tot modis ad Christianam concordiam provocans, declarant sese ecclesiae praetextu suis servisse cupiditatibus, ne quid dicam acerbius.

[595] Si ex animo taedet bellorum, dabo consilium, quo concordiam tueri possitis. Solida pax haud constat affinitatibus, haud foederibus hominum, ex quibus frequenter exoriri bella videmus. Repurgandi fontes ipsi, unde malum hoc scatet; pravae cupiditates tumultus istos pariunt. Et dum quisque suis inservit adfectibus, interim affligitur respublica, nec tamen adsequitur hoc ipsum quisque, [600] quod malis rationibus adfectat. Sapiant principes, et populo sapiant, non sibi, ac vere sapiant, ut maiestatem suam, ut felicitatem, ut opes, ut splendorem his rebus metiantur, quae vere magnos et excellentes faciunt. Sint eo animo erga rempublicam, quo pater erga familiam. Ita se magnum existimet rex, si quam optimis imperet, ita felicem, si suos felices reddiderit, ita sublimem, si quam [605] maxime liberis imperet, ita opulentum, si populum habeat opulentum, ita florentem, si civitates muito especial. A partir disso, é justo concluir que os mesmos que foram incitados pelo apelo à guerra de Júlio, não foram igualmente obedientes aos numerosos argumentos baseados na concórdia cristã do Santíssimo Papa Leão; assim, agiram com o pretexto de servir à Igreja, mas para não dizer algo mais duro - buscaram, isto sim, suas próprias ambições.

Se estais sinceramente cansados da guerra, darei um conselho com o qual podeis cultivar a paz. Uma paz sólida não nasce de laços de parentesco nem de alianças entre os homens, dos quais, muitas vezes, vemos nascer a guerra. É preciso purificar as fontes de onde nascem esses males e que dão à luz esses conflitos: as suas perversas ambições. Então, enquanto o príncipe submete-se a suas paixões, não apenas aflige-se a república, como ele tampouco consegue aquilo a que visava obter em seus vis propósitos. Que os príncipes sejam sábios; e que sejam sábios em prol do povo, e não somente para si, e que sejam verdadeiramente sábios, de tal forma que a sua majestade, a sua felicidade, a sua riqueza e o seu esplendor sejam avaliados por aquelas coisas que os fazem verdadeiramente poderosos e superiores na sociedade. Que tenham para com a república a mesma disposição do pai para com a família. Que o Rei só se considere grande se governar sobre os melhores homens; que seja feliz se tornar seus súditos felizes; glorioso, se bem governar homens livres; opulento, se o povo for opulento; 
perpetua pace florentes habeat. Atque hunc Principes animum imitentur proceres ac magistratus; omnia reipublicae commodis metiantur et hac via rectius suis consuluerint commodis. Rex qui hoc sit animo, num is facile commovebitur, ut pecuniam a suis extorqueat, quam barbaro militi numeret? [610] Suos ad famem adiget, ut impios aliquot Duces ditet? Num is suorum vitam tot periculis obiiciet? Non, opinor. Hactenus exerceat imperium, ut meminerit se hominem imperare hominibus, liberum liberis, postremo Christianum Christianis. Huic vicissim tantum deferat populus, quatenus ad publicam utilitatem conducit. Non aliud exiget bonus princeps, mali vero cupiditates retundet civium [615] consensus; absit utrimque privati commodi ratio. Plurimum honoris habeatur iis, qui bellum excluserint, qui concordiam restituerint ingenio consiliove suo; denique qui hoc modis omnibus moliatur, non ut maximam militum ac machinarum vim comparet, sed ut iis non sit opus. Quod pulcerrimum facinus, tot imperatorum unus Diocletianus animo concepisse legitur. Quod si bellum [620] vitari non potest, ita geratur, ut summa malorum in eorum capita recidat, qui belli dedere causas. e próspero, se, por uma paz perpétua, reinar sobre cidades prósperas. E que essa disposição dos príncipes seja imitada pelos seus próceres, assim como pelos magistrados. Que avaliem tudo segundo a medida do bem-estar da república e, dessa maneira, terão assegurado com mais segurança seu próprio bem-estar. Se o rei tiver essa disposição, acaso se sentirá levado a extorquir o dinheiro dos súditos para contratar mercenários bárbaros? Acaso levará os seus à fome para que enriqueça alguns generais ímpios? Acaso exporá a vida dos seus a tão grandes perigos? Não o creio. Que o príncipe impere de tal modo que se lembre sempre de que é um homem que governa homens, um homem livre que governa homens livres e, em última análise, um cristão que governa cristãos. O povo, por sua vez, que o aceite somente na medida em que seja em benefício da utilidade pública. $\mathrm{O}$ bom príncipe não exige nada mais que isso. As ambições do mau são derrubadas pelo consenso dos cidadãos. Que a lógica do interesse privado esteja ausente em ambas as partes. Maior honra tenham aqueles que evitaram a guerra e cujo engenho e conselho restituíram a concórdia. Em suma, aqueles que, por todos os meios, se esforçaram não para obter o maior número possível de soldados e máquinas de guerra, mas em tornar tudo isso desnecessário. Dentre tão grande número de imperadores que existiram, Diocleciano, segundo se lê, foi o único que concebeu em seu coração esta ação, a mais nobre 
Nunc Principes tuti belligerantur, ductores hinc crescunt, maxima malorum pars in agricolas ac plebem effunditur, ad quos nec attinet bellum, nec ipsi belli causam ullam dederunt. Ubi principis sapientia, si haec non perpendit, ubi principis animus, si haec levia ducit? Invenienda ratio, qua [625] fiat, ne toties mutentur ac velut obambulent imperia, quod omnis rerum novatio tumultum gignat, tumultus bellum. Id facile fiet, si Regum liberi intra ditionis fines elocentur, aut si quem libeat finitimis adiungere, spes omnibus successionis praecisa esto. Nec fas sit Principi ditionis portionem ullam vendere aut alienare, perinde quasi privata sint praedia, liberae civitates. Nam liberae sunt quibus rex [630] imperat, serviunt quos tyrannus premit. Nunc huiusmodi matrimoniorum vicibus fit, ut apud Hybernos natus repente imperet Indis, aut qui modo Syris imperabat, subito Rex sit Britanniae. Fitque ut neutra regio Principem habeat, dum priorem relinquit, et a posteriore non agnoscitur, nimirum ignotus alioque mundo natus. Atque interim dum illud parit, dum evincit, dum stabilit, alterum [635] exhaurit proteritque, nonnumquam amittit utrumque, dum utrumque complecti studet, vix alteri administrando idoneus. Semel inter principes conveniat, dentre todas. Agora, se não se pode evitar uma guerra, que seja travada de tal forma, que ao menos a maior parte dos males caia sobre as cabeças daqueles que causaram a guerra. Hoje em dia, porém, os príncipes combatem esmerando em sua segurança, e por isso o aumento de poder de seus generais; enquanto isso, a maior parte dos males atinge os camponeses e o povo, justamente aqueles que não tiraram qualquer proveito da guerra nem deram qualquer motivo para que ela se realizasse. Onde está a sabedoria do príncipe, se não considera essas coisas? Onde está o coração do príncipe, se pensa que isso é algo sem importância? Deve-se encontrar um modo de evitar que um reino mude de dinastia e como que passe de mão em mão, pois inovações desse tipo sempre geram confusão, e confusão gera guerras. Isso pode ser realizado de forma simples, se os filhos do rei tiverem seu poder dentro dos limites de seu feudo. Se houver algum que se interessar em acrescentar território aos seus domínios, que este seja excluído dos direitos de sucessão. Que não lhe seja lícito vender ou alienar nem a menor porção de seu feudo, como se as cidades livres fossem propriedades privadas. Dá-se, pois, o nome de cidades livres àquelas governadas por um rei, enquanto que aquelas que um tirano oprime vivem sob servidão. Hoje em dia, pelos acasos de casamentos desse tipo, acontece de um irlandês passar de repente a reinar sobre os indianos, ou de alguém, há pouco governante dos 
quid quisque debeat administrare ac ditionis fines semel datos nulla proferat aut contrahat affinitas, nulla convellant foedera; ita suam quisque portionem enitetur quam potest ornatissimam reddere, dum in unam omne studium intendet, [640] hanc conabitur rebus optimis locupletatam suis liberis relinquere. Atque hoc sane pacto futurum est, ut ubique floreant omnia. Caeterum inter sese non affinitatibus, aut factitiis sodalitatibus, sed syncera puraque amicitia copulentur, maximeque simili communique studio bene merendi de rebus humanis. Principi vero succedat vel qui genere proximus, vel qui populi suffragiis maxime iudicabitur [645] idoneus. Caeteris sat sit inter honestos haberi proceres. sírios, tornar-se rei da Inglaterra. ${ }^{128} \mathrm{E}$, enquanto isso, as duas regiões ficam sem príncipe: o primeiro, porque ele a abandonou; o segundo, porque não passa de um estrangeiro vindo de outro lugar, e não o reconhece como soberano. Enquanto o príncipe se preocupa em obter esse reconhecimento, conquistá-lo e consolidá-lo, empobrece e drena o outro reino e, por vezes, perde os dois quando tenta abraçar a ambos, pois dificilmente é capaz de governar um só. Que de uma vez por todas os príncipes estejam de acordo sobre o território que cada um deve governar e que nenhum laço de parentesco aumente ou diminua essas fronteiras que foram estabelecidas, que nenhuma aliança as destrua. Assim, cada qual se esforçará segundo suas possibilidades para governar sua região da melhor forma possível. Pois, quando estiver totalmente concentrado no cuidado de um só reino, fará o máximo para deixá-lo aos seus filhos, enriquecido por melhorias. E, desta forma, como é evidente, tudo em toda parte florescerá. Que sejam aliados não apenas por vínculos matrimoniais ou alianças contratuais, mas sim unidos por amizade sincera e pura e, acima de tudo, por um idêntico e comum amor por todo o gênero humano. Que a sucessão do rei seja atribuída quer àquele que for $\mathrm{o}$ mais próximo por consanguinidade, quer àquele que,

\footnotetext{
${ }^{128}$ Margolin (1992, p. 942) afirma que essa frase de Erasmo "poderia invocar ainda Maximiliano, que declarou guerra a Hungria (em 1490), pois a viúva de Matias Corvin, rei da Hungria, havia desposado Ladislau da Boêmia, ferindo seus pretenciosos direitos de sucessão".
} 
[646] Regium est nescire privatos adfectus et omnia publicis commodis aestimare. Ad haec longinquas peregrinationes vitet Princeps, imo pomoeria regni numquam transire velit memineritque dicti longo seculorum consensu probati: Frons occipitio prior est. Locupletatum se existimet, non si quid aliis ademerit, [650] sed si sua reddiderit meliora. Cum de bello agitur, ne adhibeat in consilium iuvenes, quibus ideo bellum placet, quod experti non sunt quantum habeat malorum, neve eos, quibus expedit turbari publicam tranquillitatem quique populi calamitatibus aluntur ac saginantur. Senes cordatos et integros accersat et quorum pietas patriae spectata sit. Nec temere ad unius aut alterius libidinem [655] bellum moveatur, quod semel coeptum haud facile finitur. Res omnium periculosissima non nisi totius populi consensu suscipiatur. Belli causae statim praecidendae sunt. Ad quaedam connivendum; comitas comitatem invitabit. Nonnumquam emenda pax. Ea si ratione subduxeris, quid bellum fuerit exhausturum, et quot cives ab exitio serves, parvo empta videbitur, etiamsi magno [660] emeris, quando praeter pelos votos do povo, for considerado o mais capaz. Quanto aos demais, que lhes baste estar entre o número dos nobres mais honrados.

A um coração régio cabe ignorar os afetos privados e estimar todas as coisas segundo o bem-estar público. Por isso, que o príncipe evite viagens a terras longínquas, ou antes, que nunca cruze os limites territoriais do seu reino. Que se recorde do ditado comprovado pelo longo consenso dos séculos: "é preciso que o mestre tenha os olhos sobre seu ofício". Que o príncipe considere que enriqueceu não se tirar algo dos outros, mas aperfeiçoando o que lhe pertence. Se há uma questão de guerra, que não convoque a conselho os jovens, aos quais a guerra sempre agrada, pois não experimentaram os muitos males que ela causa, nem consulte aqueles a quem interessa perturbar a tranquilidade pública e que são alimentados e engordados pela calamidade do povo. Que convoque um conselho de anciãos sensatos e íntegros, cuja piedade para com a pátria é comprovada. E que não inicie a guerra temerariamente, movido pelo desejo deste ou daquele, porque, uma vez iniciada, ela não se extingue com facilidade. E, uma vez que a guerra é o assunto mais perigoso de todos, que não seja decidida sem o consenso de todo o povo. As causas da guerra devem ser imediatamente extirpadas. Convém deixar passar certas coisas; a cortesia convidará à cortesia. Há ocasiões em que a paz deverá ser comprada. Se fizeres os cálculos, pesando quanto a guerra haveria de ser 
civium tuorum sanguinem plus erat bello impendendum. Ineas rationem, quantum malorum vitaris, quantum bonorum tuearis, et impendii non poenitebit. Fungantur interim suo officio praesules, sacerdotes vere sint sacerdotes, monachi professionis suae meminerint, theologi quod Christo dignum est doceant. Conspirent omnes adversus bellum, in hoc latrent [665] omnes. Pacem publice privatimque praedicent, efferant, inculcent. Tum si minus possint efficere, ne ferro decernatur, certe ne probent, ne intersint, ne rei vel tam sceleratae vel certe tam suspectae ipsis auctoribus, honos habeatur. Satis sit in bello caesis, in prophano sepulcrum dari. Si qui boni sunt in hoc genere, qui certe paucissimi sunt, non ob haec fraudabuntur suo praemio; caeterum impii, [670] quae maxima turba est, minus sibi placebunt, honore detracto.

[671] De his bellis loquor, quae vulgo Christiani cum Christianis commitunt. Nec enim idem sentio de his, fazem contra os cristãos. Não tenho, porém, custosa e o grande número de cidadãos que salvas, seu preço será considerado ínfimo, mesmo que pagues um valor alto, visto que não era só o sangue dos teus súditos que haveria de perder-se com a guerra. Calcula quanto dos males evitaste e quanto dos bens protegeste e não te arrependerás do gasto. Que, nesse ínterim, os prelados cumpram sua tarefa, que os sacerdotes sejam verdadeiramente sacerdotes, que os monges se lembrem da sua profissão e que os teólogos ensinem aquilo que é digno de Cristo. Que todos conspirem contra a guerra e contra ela todos declamem. Que preguem, promovam e inculquem a paz, quer em público quer em privado. $\mathrm{E}$ se, porventura, não conseguirem fazer com que as disputas não se resolvam pela espada, que ao menos demonstrem sua desaprovação e não compareçam, para evitar que, por sua presença, se considere honrosa uma coisa tão odiosa ou, pelo menos, tão duvidosa. Que aos que tombaram na guerra seja suficiente que lhes seja dada sepultura em solo profano. Se há algumas pessoas boas entre os guerreiros - e certamente são pouquíssimas - não por isso serão defraudadas em seu prêmio. Por outro lado, os ímpios, que são a maioria, ${ }^{129}$ estes se sentirão menos contentes nas armas com a retirada da honraria do sepulcro cristão.

Refiro-me às guerras que os cristãos 
qui simplici pioque studio vim igual julgamento sobre aquelas com as quais, incursantium barbarorum depellunt, et tomados por um sentimento puro e piedoso, suo periculo publicam tranquillitatem enfrentam as incursões dos bárbaros, e, com tuentur. Nunc trophaea sanguine tincta perigo da própria vida, protegem a tranquilidade eorum, pro quorum salute Christus suum pública. Hoje, nas igrejas, colocam-se troféus de fudit sanguinem [675] reponuntur in guerra tingidos com o sangue daqueles por cuja templis, inter apostolorum ac martyrum salvação Cristo derramou o seu sangue, por entre statuas, quasi posthac pium sit futurum, as estátuas dos apóstolos e dos mártires, como se non fieri martyres, sed facere. Abunde depois disso, fosse considerado piedoso não magnum erat, haec in foro, aut armario tornar-se mártires, mas fazê-los. Já seria o quopiam reposita servari. In sacras aedes, bastante que esses trófeus fossem exibidos no quas purissimas esse decet, nihil recipi fórum ou em um armário qualquer, mas não convenit, quod sanguine sit inquinatum. devem expô-los os templos sagrados, que devem Sacerdotes deo sacri nusquam adsint, nisi ser os mais puros e de forma alguma convém que ad dirimenda bella. In haec si recebam qualquer objeto manchado de sangue. consentiant, [680] si eadem ubique Que os sacerdotes não se apresentem pelo Deus inculcent, plurimum habitura momenti sagrado, a não ser para dirimir as guerras. Se est. Quod si hic fatalis est humani ingenii nisso concordarem, se em todos os lugares morbus, ut prorsus absque bellis durare inculcarem o mesmo, enorme influência hão de nequeat, quin potius malum hoc in Turcas ter. Ora, se a guerra é uma fatal e doentia effunditur, tametsi praestabat et hos propensão do engenho humano, de modo que doctrina, bene factis, vitaeque innocentia não lhe é possível viver absolutamente sem ela, ad Christi religionem allicere, quam por que não se dirige esse mal inevitável contra armis adoriri. Attamen si bellum, ut os turcos, embora fosse preferível atraí-los para a diximus, omnino vitari non potest, illud religião de Cristo por meio da doutrina, dos bons certe levius [685] sit malum, quam sic costumes e de uma vida de inocência, do que impie Christianos inter se committi atacá-los com armas. Se, contudo, como collidique. Si mutua caritas illos non dissemos, a guerra não pode ser completamente adglutinat, certe coniunget utcumque evitada, de todo modo atacar os turcos é um mal communis hostis et qualiscumque menor do que os cristãos se enfrentarem e se syncretismus erit, ut absit vera concordia. colidirem mutuamente de maneira tão perversa. Se o amor mútuo não os une, pelo menos, de 
[688] Postremo magna pars pacis est, ex animo velle pacem. Quibus enim pax vere cordi est, hi omnes pacis occasiones arripiunt; quae obstant, aut negligunt aut [690] amoliuntur ; permulta ferunt, dum tantum bonum sit incolume. Nunc ipsi bellorum seminaria quaerunt, quod ad concordiam facit, elevant aut dissimulant etiam; quod ad bellum tendit, ultro exaggerant exulcerantque. Pudet referre ex cuiusmodi nugis quantas excitent tragoedias et ex quam minuta scintillula quae rerum tempestates exoriantur. Tunc illud iniuriarum agmen venit in mentem [695] et suum quisque malum sibi exaggerat, at benefactorum interim profunda oblivio, ut iures adfectari bellum. Et saepe principum privatum quiddam est, quod orbem ad arma compellit; at plus quam publicum esse debet, ob quod bellum suscipiatur. Quin ubi nihil subest causae, ipsi dissidiorum causas sibi fingunt, regionum vocabulis ad odiorum alimoniam abutentes et hunc stultae plebis [700] errorem alunt magnates, et in suum abutuntur compendium, alunt sacerdotes quidam. Anglus hostis est Gallo, nec $o b$ aliud, nisi quod Gallus est. Scoto alguma forma, um inimigo comum poderia unilos, e haveria ao menos uma espécie de harmonia, ainda que longe de ser a verdadeira concórdia.

Finalmente, o primeiro e primordial passo para a paz se realiza ao desejar sinceramente a paz. De fato, quem tem o coração realmente repleto do desejo de paz aproveita todas as oportunidades para estabelecê-la; diante dos obstáculos, negligencia-os ou elimina-os, resigna-se a suportar muita coisa, contanto que se consiga manter incólume um tão grande bem. Atualmente, entretanto, são os próprios príncipes que buscam disseminar as guerras; enfraquecem e até dissimulam tudo o que promove a concórdia; por iniciativa própria, exageram e instigam tudo o que leva à guerra. Envergonhome de mencionar com que tipo de ninharia instigam tão grandes tragédias e de quão diminutas centelhazinhas nascem tão grandes tempestades. Então ressurge-lhes na mente aquela ruptura provocada por uma tropa de injúrias, e cada qual exagera para si mesmo o mal anteriormente sofrido, mas esquece de todos os benefícios recebidos, de forma a que endosses o direito a fazer a guerra. Muitas vezes, um interesse particular qualquer dos príncipes é capaz de levar o mundo inteiro às armas. Ora, aquilo que ocasiona a guerra deve ser mais do que é público. Mais ainda: onde não há uma causa real para o conflito, eles mesmos inventam motivos para divisões, pronunciando os nomes 
Britannus infensus est, nec aliam ob rem, nisi quod Scotus est. Germanus cum Franco dissidet, Hispanus cum utroque. $\mathrm{O}$ pravitatem, disiungit inane loci vocabulum. Cur non potius tot res conciliant? Male vis Britannus Gallo, cur non potius [705] bene vis homo homini, Christianus Christiano? Cur res frivola plus apud istos potest, quam tot naturae nexus, tot Christi vincula? Locus corpora dirimit, non animos. Separabat olim Rhenus Gallum a Germano, at Rhenus non separat Christianum a Christiano. Pyrenaei montes Hispanos a Gallis seiungunt, at iidem non dirimunt Ecclesiae communionem. Mare dirimit Anglos a Gallis, at non dirimit [710] religionis societatem. Paulus Apostolus indignatur audire inter Christianos has voces: Ego sum Apollo, ego sum Cephae, ego sum Pauli, nec impia cognomina sinit secare Christum omnia conciliantem et nos commune patriae vocabulum gravem causam iudicamus, cur gens in gentis internecionem tendat? Ne id quidem satis nonnullorum animis bellorum avidis; prave dataque opera dissidiorum [715] ansas quaerunt, ipsam dividunt Galliam, et ea vocabulis distrahunt, quae nec maria nec montes nec vera regionum nomina da região inimiga de tal forma que alimentem os ódios; e não apenas os magnatas, como também alguns sacerdotes, nutrem esse engodo da plebe estulta para seu proveito pessoal. Dizem que o inglês é inimigo do francês, sem qualquer outra razão, exceto pelo simples fato de ser francês. O escocês é odioso para o bretão, não por outro motivo senão por ser escocês. $\mathrm{O}$ alemão discorda do francês e o espanhol, dos dois. Ó perversidade! O vão vocábulo de lugar desune. Por que não podem antes tantas coisas unir? Tu, bretão, queres mal ao francês. Por que não podes, como ser humano, querer bem a outro ser humano; como cristão, a um outro cristão? Por que uma tolice como essa tem mais poder sobre os homens do que tão grande número de elos da natureza, de tantos vínculos instituídos por Cristo? A geografia é capaz de separar os corpos, não as almas. O Reno separava, antigamente, o território gaulês do germânico, mas o Reno não separa o cristão do cristão. Os Pirineus separam os espanhóis dos franceses, mas não os separam da comunhão da Igreja. Se o mar separa os ingleses dos franceses, não rompe a unidade da religião. O apóstolo Paulo indigna-se ao ouvir entre os cristãos as seguintes palavras: "Eu sou de Apolos, eu sou de Cefas, eu sou de Paulo"; ${ }^{130}$ e não tolera que cognomes ímpios dissolvam a conciliação universal realizada por Cristo. Como podemos julgar que o nome da pátria de cada um

\footnotetext{
130 "Ego quidem sum Pauli ego autem Apollo ego vero Cephae ego autem Christi divisus est Christus" (Prima ad Corinthios 1,12-13).
} 
distrahunt. E Gallis Germanos faciunt, ne vel nominis consortio coalescat amicitia. $\mathrm{Si}$ in actionibus odiosis, velut divortii, nec litem facile recipit iudex nec quamlibet admittit probationem, cur isti in re omnium odiosissima quamlibet frivolam causam admittunt? [720] Quinpotius id, quod res est, cogitant, mundum hunc communem esse patriam omnium, si patriae titulus conciliat, ab iisdem maioribus ortos omneis, si facit amicos sanguinis affinitas. Ecclesiam unam esse familiam ex aequo communem omnibus. $\mathrm{Si}$ domus eadem copulat necessitudines, in hanc partem ingeniosos esse par est. Toleras quaedam in socero non ob aliud, nisi quod socer est, et nihil toleras [725] in eo, qui religionis consortio frater est? Multa condonas generis propinquitati, et nihil condonas affinitati religionis? Certe nullum vinculum arctius alligat, quam Christi sodalitas. Cur id solum ob oculos obversatur, quod animum exulcerat? Si paci faves, sic cogita potius : in hoc laesit, sed saepe alias profuit, aut alieno impulsu laesit. seja justificativa para que um povo se esforce por exterminar outro povo? Mas nem isso basta para alguns espíritos ávidos de guerras que, de forma perversa e acintosa, se empenham em achar pretextos para dissensões. Procuram, inclusive, dividir a França, e a desagregam através de palavras, que nem os mares, nem os montes, nem as diferentes províncias têm poder para desunir. Chamam a franceses "alemães", para impedir que a amizade se fortaleça, ainda que seja pela comunhão de nome. Se nos processos litigiosos, como, por exemplo, o divórcio, o juiz não aceita facilmente a causa nem admite irrestritamente qualquer prova, por que os homens admitem qualquer causa frívola para a guerra, que é a mais litigiosa de todas as coisas? Por que não pensam antes no seguinte? Se a mera designação a pátria é capaz de unir os concidadãos, este mundo é a pátria comum de todos; se a afinidade de sangue é capaz de estabelecer relações de amizade, todos nascemos dos mesmos antepassados; se o lar em comum forma laços de parentesco, a Igreja é uma só família, comum a todos por igual. É justo que se mostrem engenhosos também nesse sentido. Toleras algo desagradável em teu sogro pelo simples fato de ele ser teu sogro, e não toleras o quer for naquele que, pela comunidade de religião, é teu irmão? Se perdoas muitas coisas pelo parentesco consanguíneo, não perdoas os que são teus parentes pela religião? Ora, o fato é que nenhum vínculo liga com maior força do que a 
[730] Postremo, quemadmodum apud Homerum dissidii causas, quod inter Agamemnonem et Achillem intercesserat, in Aten Deam reiiciunt, qui vocant ad concordiam, ita quae excusari non possunt, aliquando fatis imputentur, aut malo cuipiam, si libet, genio, et in haec odium ab ipsis hominibus transferatur. Cur magis ad perniciem suam sapiunt, quam ad tuendam felicitatem? Cur ad [735] malum, quam ad bonum sunt oculatiores? Qui paulo cordatiores sunt, expendunt, consyderant, circumspiciunt, priusquam privatum quoque negotium aggrediantur. Et clausis oculis praecipites in bellum ipsi sese coniiciunt, praesertim cum semel admissum, excludi non possit, quin e pusillo fit maximum, ex uno plura, ex incruento cruentum, maxime cum haec procella non unum aut alterum [740] affligat, sed universos pariter involvat. Quod si vulgus haec parum expendit, certe principis et optimatum partes sunt, igual. Se o povo não compreende essas coisas, fraternidade em Cristo. Por que só se apresenta aos olhos aquilo que a mente abomina? Se tu procuras a paz, é melhor que tu cogites contigo mesmo: "se nisso ele me magoou, talvez incitado por alguém, em outros casos, porém, ele me tem sido útil".

Finalmente, assim como em Homero ${ }^{131}$ aqueles que aconselham a concórdia lançaram toda culpa do atrito entre Agamenon e Aquiles em Ates, deusa da vingança, da mesma forma se imponha aos fados, ou, talvez, a algum mau gênio, a culpa daquelas ofensas que são indesculpáveis, transferindo para esses seres imaginários o ódio contra os homens. Por que os homens são mais inteligentes para sua própria destruição do que para a preservação do seu bem estar? Por que são mais cuidadosos com o mal do que com o bem? Aqueles que têm um pouco de sensatez preferem pesar, considerar e observar antes de se lançarem a qualquer negócio privado. Mas, ainda assim, eles se lançam de cabeça na guerra, com os olhos fechados, apesar de a guerra ser um tipo de mal que, uma vez criado, não pode ser extirpado facilmente. Antes, a partir de um pequeno conflito, faz-se um enorme; de uma só batalha, muitas; de um ataque incruento, uma carnificina; chega-se ao cúmulo com esta procela que não abate apenas um ou dois, mas atinge a todos por

\footnotetext{
${ }^{131}$ Cf. Homero. Ilíada. IX, 505; XIX, 91.
} 
haec secum reputare. Sacerdotum est ista rationibus omnibus infulcire, volentibus ac nolentibus ingerere. Haerebunt tandem si nusquam non audiantur.

[744] Ad bellum gestis? Primum inspice, cuiusmodi res sit pax, cuiusmodi bellum, [745] quid illa bonorum, quid hoc malorum secum vehat atque ita rationem ineas, num expediat pacem bello permutare. $\mathrm{Si}$ res quaedam admirabilis est regnum undique rebus optimis florens bene conditis urbibus, bene cultis agris, optimis legibus, honestissimis disciplinis, sanctissimis moribus, cogita tecum: haec felicitas mihi perturbanda est, si bello. Contra si quando conspexisti ruinas urbium, [750] dirutos vicos, exusta fana, desolatos agros, et id spectaculum miserandum, ut est, visum est, cogita hunc esse belli fructum. Si grave iudicas sceleratam conductitiorum militum colluviem in tuam regionem inducere, hos civium tuorum malo alere, his inservire, his blandiri, immo horum arbitrio te ipsum ac tuam incolumitatem committere, fac cogites hanc esse belli conditionem. Si abominaris [755] latrocinia: haec docet bellum. Si exsecraris parricidium: hoc in cabe aos príncipes e aos líderes refletir sobre tudo isso consigo mesmos. Com maior razão ainda, cabe aos sacerdotes, querendo ou não, defender com todos os argumentos a causa pacífica. Obterão o seu prêmio no final, mesmo que em nenhuma parte sejam ouvidos.

Anseias pela guerra? Primeiro, observa bem que é a paz e que é a guerra, que bens traz consigo a primeira e que males porta consigo a segunda, e assim, ponderarás se vale a pena trocar a paz pela guerra. Se um reino, florescente em toda parte com tudo o que há de melhor, com cidades bem construídas, com campos bem cultivados, com ótimas leis, com o ensino mais honesto e com os costumes mais santos, é algo admirável, considera contigo mesmo: se faço a guerra, essa minha felicidade deve ser perturbada. Por outro lado, se, ao contemplares as ruínas das cidades, as aldeias destruídas, os templos em chamas e os campos desolados, isso te pareceu, tal como de fato é, um espetáculo lastimável, pensa que são estes os frutos da guerra. Se julgas perigoso a turba criminosa dos mercenários ser conduzida para teu país, com a desgraça dos teus súditos tu os alimentares, ao servi-los e bajulá-los, e mais, entregares a ti mesmo e a tua segurança ao arbítrio desses homens, dedica-te a pensar que essa é a condição da guerra. Se abominas os latrocínios, a guerra é que os ensina; se execras os parricídios, na guerra é que se aprendem. De fato, que hesitação vai sentir, quando levado por forte emoção a 
bello discitur. Nam qui vereatur unum occidere commotus, qui levi auctoramento conductus tot homines iugulat? Si praesentissima Reipublicae pestis est legum neglectus: silent leges inter arma. Si foedum existimas stuprum, incestum, et his turpiora: horum omnium bellum magister est. Si fons omnium malorum est impietas [760] et religionis neglectus: haec belli procellis prorsus obruitur. $\mathrm{Si}$ iudicas pessimum esse reipublicae statum, cum plurimum possunt qui pessimi sunt : in bello regnant sceleratissimi, et quos in pace suffigas in crucem, horum in bellis primaria est opera. Quis enim melius per devia ducet copias quam latro exercitatus? Quis fortius diripiet aedes aut spoliabit templa, quam parietum perfossor aut sacrilegus? [765] Quis animosius feriet hostem et hauriet ferro vitalia, quam gladiator aut parricida? Quis aeque idoneus ad iniiciendum ignem urbibus aut machinis, quam incendiarius? Quis aeque contemnet fluctus marisque discrimina, ac pirata diutinis praedationibus exercitus? Vis palam cernere, quam res sit impia bellum: matar um só homem, quem, em troca de um pequeno soldo, degola tão grande número de homens? Se a praga se abate sobre a república, há indeferença pela justiça: porque as leis silenciam ${ }^{132}$, em meio às armas ${ }^{133}$. Se o estupro, a violência e coisas ainda mais nefandas que estas te parecem torpes, lembra-te de que é justamente a guerra a mestra de todas as ações mais horrendas. Se a impiedade e a negligência para com a religião são a fonte de todos os males, considera que ela é totalmente destruída pelas procelas da guerra. Se julgas que a pior situação da república é quando muito podem os que são péssimos: na guerra reinam os mais criminosos e têm proeminência aqueles que, em tempos de paz, condenas à cruz. Pois quem pode guiar as tropas por caminhos tortuosos melhor do que um experiente assaltante de estradas? Quem está mais seguro em roubar casas ou pilhar templos do que o arrombador ou o sacrílego? ${ }^{134}$ Quem é mais valente em debelar o inimigo e furar-lhe as entranhas com a espada do que o gladiador e o parricida? Quem é mais hábil em tocar fogo nas cidades ou nas máquinas de guerra do que o incendiário? Quem poderia suportar melhor as ondas e os perigos do mar do que o pirata exercitado dia e noite nos saques? Queres ver com clareza quanto é ímpia uma guerra?

\footnotetext{
132 Cicero. Mil. 4, 10

133 A expressão "silent leges inter arma" remonta a Cícero (Pro Milone, 4,10) e Luciano (Pharsade, 1,277): "leges bello siluere coactae".

${ }^{134}$ Plauto. Pseud. 9, 8, 6.
} 
animadverte per quos geritur.

[770] Si pio principi nihil antiquius esse debet, quam suorum incolumitas, huic bellum in primis invisum sit, oportet. Si principis felicitas est imperare felici, pacem potissimum amplecti debet. Si praecipue optandum bono principi, ut imperet quam optimis, bellum detestetur oportet, unde scatet omnis impietatis sentina. Si suas opes esse putat quidquid cives possident, bellum omnibus rationibus [775] vitet. Quod ut felicissime cadat, certe facultates omnium atterit et quod honestis artibus partum est, in immanes quosdam carnifices erogandum. Iam illud etiam atque etiam perpendant suam cuique blandiri causam et suam cuique spem arridere, cum illa saepenumero pessima sit, quae commoto videatur aequissima. Et haec non raro fallit. Sed finge causam iustissimam, finge exitum [780] belli prosperrimum, rationem fac ineas omnium incommodorum quibus gestum est bellum et commoditatum quas peperit victoria, et vide num tanti fuerit vincere. Vix umquam victoria contingit incruenta. Iam habes tuos humano sanguine pollutos. Ad haec supputa morum publicaeque disciplinae iacturam nullo compendio sarciendam. Exhauris tuum fiscum, expilas populum, oneras bonos,
Observa quem as faz.

Se para um príncipe piedoso nada deve ser mais precioso do que a segurança dos seus súditos, é necessário que a guerra lhe seja detestável acima de todas as coisas. Se a felicidade do príncipe consiste em governar para a felicidade do seu povo, ele deve optar preferencialmente pela paz. Se o principal objetivo do bom príncipe consiste em governar sobre os melhores, é necessário que odeie a guerra, da qual jorra o esgoto de todo tipo de impiedade. Se o príncipe pensa que são riquezas suas os bens que seus súditos possuam, então que evite a guerra por todas as razões, pois é certo que esta, ainda que venha a ser vencida, arruína os recursos de todos e as riquezas conquistadas pelo trabalho honesto têm de ser gastas com o sustento de certos carrascos selvagens. É necessário ainda que considerem mais e mais que todo homem lisonjeia-se com sua própria causa e a própria esperança que acalenta lhe parece mais risonha, a qual, ainda que muitas vezes se torne a pior das realidades, induz ao erro, e parece justíssima a quem está perturbado. Supõe a mais legítima das causas; considera o mais feliz desfecho para uma guerra; calcula todos os prejuízos inerentes ao estado de guerra e o lucro gerado pela vitória. E vê se a vitória compensou o investimento. Quase nunca ocorre uma vitória sem sanguinolência; o que conquistaste estará contaminado de sangue humano. Soma a isso que, para obter a vitória, os 
[785] ad facinus excitas ímprobos; neque vero confecto bello protinus et belli reliquiae sopitae sunt. Obsolescunt artes, includuntur negociatorum commercia. Ut hostem includas, prius temet ipsum a tot regionibus cogeris excludere. Ante bellum omnes finitimae regiones tuae erant, pax enim rerum commerciis facit omnia communia. Vide quantam rem egeris: nunc vix tua est, quae maxime tua [790] est ditio. Ut oppidulum excindas, quot machinis, quot tentoriis opus est? Imitatitiam urbem facias oportet, ut veram evertas, at minoris aliud verum oppidum exstrui poterat. Ne liceat hosti prodire ex oppido, tu exsul a patria sub dio dormis. Minoris constaturum erat, aedificare nova moenia, quam aedificata machinis demoliri. Ut ne computem hic, quod pecuniarum effluit inter exigentium, [795] recipientium, ac ducum digitos, quae sane pars est non minima. Quod si horum singula ad verum calculum revoces, ni compereris decima impendiorum parte pacem redimi potuisse, patiar aequo animo me profligari undique. Sed parum excelsi animi tibi videare, si quid remittas iniuriarum? Immo nullum est certius argumentum humilis animi minimeque regii quam ulcisci. Maiestati tuae [800] non nihil decedere putas, si cum finitimo costumes e a ordem pública são devastados, e isso está perdido sem possibilidade de reparo. Exaures o teu tesouro, expolias o povo, oneras os bons, incitas os ímprobos para o crime. E, acabada a guerra, não creias que as suas consequências se esvairiam imediatamente. As artes fragilizam-se, os tratos comerciais cessam. Para sitiares o inimigo, és forçado a abandonar primeiro muitas regiões. Antes da guerra, todos os territórios vizinhos eram teus, pois, com as trocas comerciais, a paz torna todos os bens comuns. Presta atenção no que fizeste. Com a guerra, mal se pode dizer agora que te pertence o teu próprio território. Quantas máquinas de guerra e quantas tendas são necessárias para destruir uma cidadezinha! É preciso que construas quase uma cidade falsa para conquistares uma verdadeira, quando seria possível, por preço menor, construir outra cidade verdadeira. Para impedir que o inimigo saia da cidade sitiada, dormes ao ar livre, exilado da tua pátria. Sairia muito mais barato levantar novas muralhas do que demolir as já construídas com máquinas de guerra. Isso sem contar a quantidade de dinheiro que deve ser repassado às mãos dos cobradores, dos recebedores e dos generais, que, aliás, não é de modo algum a menor parte de teus gastos. Se depois de calculares um orçamento exato de cada um desses itens, não chegares à conclusão de que a paz poderia ter sido comprada pela décima parte do que a guerra custou, darei de bom grado 
principe agens et fortasse cognato aut affini, fortassis alias bene de te merito, de tuo iure decedas aliquantulum. At quanto humilius deiicis maiestatem tuam, dum barbaris cohortibus et infimae sceleratorum feci numquam explendae auro subinde litare cogeris; dum ad Cares vilissimos simul ac nocentissimos blandus ac supplex mittis legatos; dum [805] tuum ipsius caput, dum tuorum fortunas illorum credis fidei, quibus nihil est neque pensi neque sancti. Quod siquid iniquitatis videbitur habere pax, cave sic cogites: hoc perdo, sed tanti pacem emo.

[808] At dixerit argutior aliquis: Facile donarim, si res ad me privatim pertineat. Princeps sum, negotium publicum, velim nolim, ago. Non facile permissão para que me expulsem de toda parte. Contudo, a ti pareça pouca grandeza de espírito se retribuíres alguma das ofensas? Na verdade, eu te asseguro que não há prova mais certa de um espírito mesquinho e nada régio do que o desejo de vingança. Julgas rebaixar tua majestade se, de modo magnânimo, renuncias a um pouquinho de teu direito, quando tens uma pendência com um príncipe vizinho, que, aliás, bem pode ser teu parente ou chegado por afinidade, e que, talvez, em outra ocasião te tenha feito o bem. Mas como humilhas a tua majestade muito mais, quando és forçado a aplacar com ouro os insaciáveis esquadrões de bárbaros, ou, ainda pior, a mais vil ralé dos criminosos, quando, numa posição de lisonja e súplica, envias embaixadores para contratar os mais vis e perversos mercenários ${ }^{135}$, quando fazes a tua própria cabeça e a sorte dos teus súditos depender da lealdadade desses teus aliados, para quem não existe nada de sagrado ou respeitável! Quanto a isso, se parecer que a paz tem algo de iníquo, evita pensar assim: "Eu perco isto", mas pensa antes "por tanto, compro a paz".

Mas algum príncipe mais arguto poderia objetar: "se dependesse só de mim, perdoaria com facilidade. Como sou príncipe, queira ou não queira, devo cuidar de um interesse

\footnotetext{
${ }^{135}$ Segundo Diodoro Sículo, Carés teria sido um general ateniense que viveu no século IV a. C. Carés passou para a história como traidor porque estando os gregos em guerra contra os argivos, Carés evitou atacar os inimigos e feriu os aliados de Atenas, promoveu uma guerra civil e desacreditou seu povo diante de seus aliados (Diodoro Sículo, Biblioteca Histórica, Livro XV, 7.3)
} 
bellum suscipiet, [810] qui nihil nisi publicum spectat; atqui contra videmus omneis belli causas ex his rebus nasci, quae nihil ad populum pertineant. Vis hanc aut illam ditionis partem vindicare: quid istud ad populi negotium? Vis ulcisci qui filiae renunciavit: quid hoc ad rempublicam? Haec expendere, haec perspicere vere sapientis vereque magni est principis. Quis umquam aut latius imperavit aut splendidius [815] Octavio Augusto ${ }^{42}$ At is cupiebat etiam deponere imperium, si quem vidisset reipublicae magis salutarem principem. Merito laudata est ab egregiis auctoribus vox illa cuiusdam imperatoris: Pereant, inquit, filii mei, si quis alius melius sit reipublicae consulturus. Hos animos reipublicae praestiterunt homines impii, quod ad Christi religionem attinet: et Christiani principes usque [820] adeo vilem ducunt populum Christianum, ut gravissimo orbis incendio privatas suas cupiditates vel ulcisci velint vel explere? público". Ora, quem atende exclusivamente ao interesse público não aceitará a guerra com facilidade. A verdade é que também aqui vemos que quase todas as causas da guerra nascem de interesses que em nada concernem ao povo. Queres reivindicar teu domínio sobre este ou aquele feudo? Pois que proveito tira o povo desse projeto? Queres tirar a desforra do príncipe que necusou desposar a tua filha ${ }^{136}$ ? Mas o que isto tem a ver com os interesses da república? Refletir sobre essas questões e observar todas essas circunstâncias é próprio de um príncipe sábio e grande. Quem é que reinou de modo mais esplêndido e por tanto tempo do que Otávio Augusto? Mas ele próprio desejava vivamente renunciar ao império, caso encontrasse alguém que pudesse vir a ser um príncipe mais capaz de promover a república ${ }^{137}$. Com mérito foi louvado pelos autores egrégios aquela fala do imperador: "Pereçam os meus filhos, se houver alguém que cuide melhor da república!". ${ }^{138}$ Homens ímpios, do ponto de vista da religião de Cristo, foram capazes de cultivar esses pensamentos acerca da república, e, agora, príncipes cristãos desprezam

\footnotetext{
${ }^{42}$ deponere imperium (cf. Suet. Aug, 28)

${ }^{136}$ Segundo Margolin (1992, p. 950), alusão à filha do Imperador Maximiliano, Margarida da Áustria, noiva de Carlos VIII, mas rejeitada por seu pai em 1492.

${ }^{137}$ Como tradutor, tenho convicção de que Erasmo utiliza a palavra república em um sentido muito próximo ao que hoje denominamos estado. O príncipe não protege a república entendida como sistema de governo oposto à monarquia, mas o estado como um aparato que visa o bem comum. Conforme Suetônio (Iulius, 83), César Augusto foi o fundador do Império Romano e primeiro Imperador que administrou o império por mais de 40 anos. Augusto iniciou o período de paz relativa chamado de Pax Romana. Embora tenha expandido o império, estabeleceu relações pacíficas com outros reinos e reformou o sistema tributário, desenvolveu as vias romanas com um sistema oficial de correio e outras obras arquitetônicas em Roma, obtendo grande popularidade.

${ }^{138}$ Cf. Hist. Aug., Auid. Cast. 2, 8.
} 
[822] Iam audio quosdam ita tergiversantes, ut negent se tutos esse posse, nisi vim improborum acriter propellant. Cur igitur inter innumeros imperatores Romanos soli Antonini, pius et philosophus, petiti non sunt? Nisi quod nemo tutius [825] regnat, quam qui paratus est et deponere utpote quod reipublicae gerat, non sibi. Quod si nihil vos movet, neque naturae sensus neque pietatis respectus neque tanta calamitas, certe Christiani nominis probrum animos vestros in concordiam redigat. Quota mundi portio tenetur a Christianis? Atque haec tamen est illa civitas in aedito monte sita, spectaculum facta deo et hominibus. [830] At quid sentire putandum est, quid loqui, quae probra in Christum evomere Christiani nominis hostes, ubi vident Christianos sic inter sese concertare, julgar que pensam? O que dizem? Que espécie levioribus de causis quam ethnici, de ofensas se espera que vomitem contra Cristo crudelius quam impii, machinis tetrioribus quam ipsi? Quorum inventum est bombarda? Nonne Christianorum? Et quo res sit indignior: his induuntur apostolorum nomina, insculpuntur o povo cristão a tal ponto que incendeiam o mundo inteiro para saciar sua sede de cobiça ou seu desejo de vingança?

Já ouço o argumento de alguns que me criticam. Negam que se possa conservar sua segurança se não lutarem de forma acerba contra o ímpeto dos ímprobos. Por que, então, dentre os inúmeros imperadores romanos, somente os Antoninos $^{139}$, o Pio e o Filósofo, não foram atacados? Não será porque ninguém reina com maior segurança do que aquele que está preparado para renunciar, sabendo que serve aos interesses da república e não a seus próprios caprichos? Se nada disso vos comove, nem o bom senso da natureza, nem o respeito oriundo da piedade, nem a visão de tantas calamidades, que ao menos o opróbrio que recai sobre o nome cristão conduza as vossas mentes à concórdia. Qual é a porção do mundo pertencente aos cristãos? Esta é, no entanto, aquela cidade edificada sobre um monte elevado, espetáculo para Deus e para os homens. Mas que se deve os inimigos do nome cristão, ao verem o modo como os cristãos lutam entre si, movidos por causas mais insignificantes do que as dos pagãos, de modo mais cruel do que os ímpios e com máquinas mais terríveis do que aquelas que

\footnotetext{
${ }^{139} \mathrm{O}$ Antonino Pio mencionado por Erasmo seria o imperador romano da dinastia Nerva-Antonina que governou entre os anos de 138 e 161 e Marcus Antonius philosophus, que foi imperador conhecido sob o nome de Marcus Aurelius Antoninus (161-180) .(Historia Augusta. Ant. Pius, 13,3; Marc. Ant. Philos. 18,5).
} 
imagines. O crudelis [835] irrisio. Paulus ille pacis hortator perpetuus tartaream machinam torquet in Christianum? $\mathrm{Si}$ cupimus Turcas ad Christi religionem adducere, prius ipsi simus Christiani. Numquam hoc illi credent, si quod est; perspiciant nusquam magis saevire, quam apud Christianos, id quod Christus unum omnium maxime detestatus est. Et quod Homerus ethnicus demiratur in ethnicis, cum suavium [840] etiam rerum satietas sit, somni, cibi, potus, choreae, musices, belli infelicis nullam esse satietatem: id apud eos verissimum est, quibus ipsum etiam belli vocabulum abominandum esse oportuit. Roma furiosa quondam illa bellatrix tamen Iani sui templum aliquoties vidit clausum. Et qui convenit apud vos nullas esse bellandi ferias? Quonam ore praedicabitis eis Christum pacis auctorem ipsi [845] perpetuis dissidiis inter vos tumultuantes? Iam quos putatis animos addit Turcis vestra discordia? Nihil enim facilius quam vincere dissidentes. Vultis illis esse formidabiles? Concordes estote. Cur ultro vobis et praesentis vitae iucunditatem invidetis et a futura felicitate vultis excidere? Multis malis per se obnoxia est vita mortalium, magnam molestiae eles mesmos usam? Quem inventou os canhões? Acaso não foram os cristãos? E, para tornar isso ainda mais indigno, revestem as armas de destruição com os nomes dos Apóstolos e esculpem sobre elas imagens de santos. Ó cruel escárnio! Que o nome de Paulo, o perpétuo arauto da paz, seja dado a uma máquina infernal apontada contra os cristãos! Se desejamos converter os turcos à religião de Cristo, é necessário que primeiro nós mesmos sejamos cristãos. Nunca eles acreditarão, se constatarem em toda parte - e isto é inegável - que grassa em nenhum lugar mais que entre os cristãos aquilo que Cristo destestou acima de todas as coisas. E aquilo que um poeta pagão como Homero ${ }^{140}$ espanta a pagãos, quando constata que há saciedade até para as coisas agradáveis da vida, como o sono, a comida, a bebida, as danças e a música, mas não para a infeliz guerra, antes deveria tê-lo espantado ver que era a coisa mais verdadeira do mundo para homens que deveriam abominar até o vocábulo guerra. Até mesmo a outrora impetuosa Roma, aquela cidade guerreira, viu muitas vezes fechado o seu templo de $\mathrm{Jano}^{141}$. E não há entre vós alguém que concorde que se faça uma trégua na guerra? Como podereis abrir a boca para pregar aos turcos sobre Cristo, o autor da paz, se vós mesmos vos confrontais em perpétuas divisões internas? Já pensastes que reação vossa discórdia

\footnotetext{
${ }^{140}$ Cf. Hom. Il. XIII, 636-639.

${ }^{141}$ Cf. Suet. Aug. 22.
} 
partem adimet concordia, [850] dum mutuis officiis alius alium aut consolatur aut iuvat. Si quid boni obtinget, id tum suavius tum communius reddet concordia, dum amicus impertit amico et benevolus benevolo gratulatur. Quam frivola sunt quamque mox peritura, pro quibus inter vos tumultus est. Mors omnibus imminet, non minus Regibus quam plebeiis. Quos tumultus ciet animalculum mox fumi in morem evaniturum? [855] In foribus adest aeternitas. Quorsum attinet, pro rebus istis umbraticis perinde moliri, quasi vita haec esset immortalis? O miseros, qui felicem illam piorum vitam non credunt aut non sperant; impudentes, qui sibi pollicentur e bellis ad eam iter esse, cum illa nihil sit aliud quam ineffabilis quaedam felicium animorum communio, cum iam ad plenum continget, quod Christus tam enixe [860] rogaverat patrem coelestem, ut sic inter se iungerentur illi, quemadmodum ipse patri iunctus esset. Ad hanc summam concordiam qui possitis esse idonei, nisi eam interim pro virili meditemini? Ut non subito ex spurco helluone fit angelus, ita non subito ex bellatore sanguinario martyrum et divorum socius. Eia satis iam superque fusum est Christiani, si parum est humani sanguinis, satis in produz nos turcos? Pois nada mais fácil do que vencer aqueles que não se entendem. Quereis tornar-vos temíveis para eles? Ponde-vos de acordo! Por que recusais deliberadamente os prazeres da vida presente, e quereis perder os da felicidade futura? Por si só a vida dos mortais está repleta de muitos males, mas grande parte desse incômodo seria aliviada pela concórdia que faz que uns aos outros se ajudem ou, ao menos, consolem-se com serviços mútuos. Se algum benefício for dado a alguém, a concórdia fará tal bem tanto mais agradável quanto mais for extensivo aos demais, o amigo partilhando-o com o amigo e sentindo alegria com a alegria do outro. Como as guerras são frívolas e por quão levianas questões se promove o conflito entre vós. A morte ameaça a todos, e não menos aos reis que aos plebeus. Quantas discórdias produz um animalzinho desprezível que logo desaparecerá como fumaça ao vento. Ao sair da vida, a eternidade está às portas. Que proveito há em construir suas aspirações em coisas tão vãs, como se a vida presente fosse imortal? Ó miseráveis, que não acreditam ou não esperam aquela vida feliz dos homens piedosos! Homens impudicos, que se persuadem de que existe um caminho que leva das guerras àquela vida, quando ela não é senão a inefável comunhão de todas as almas bem-aventuradas, quando se realizar finalmente em toda a plenitude aquilo que Cristo havia pedido tão assiduamente ao Pai Celeste, que todos se unissem como o Filho está 
[865] mutua debacchatum exitia, satis hactenus Furiis Orcoque litatum, satis diu quae Turcarum pascat oculos. Acta est fabula. Saltem aliquando post nimium diu toleratas bellorum miserias resipiscite. Quicquid hactenus insanitum est, fatis imputetur. Placeat Christianis, quae quondam profanis placuit, superiorum malorum oblivio. Posthac communibus consiliis in pacis studium incumbite. [870] Et sic incumbite, ut non stupeis, sed solidis atque adamantinis vinculis coeat, numquam dirumpenda.

[872] Vos appello, principes, de quorum nutu potissimum pendent res mortalium, qui Christi principis imaginem inter mortales geritis. Agnoscite regis vestri vocem ad pacem vocantis, existimate totum orbem diutinis fessum malis hoc a vobis [875] flagitare. unido ao Pai. Não podeis ser dignos de gozar essa suma concórdia, a não ser que a prepareis o mais possível. Assim como é impossível que subitamente um glutão sujo se transforme em um anjo, assim também não é de repente que de um guerreiro sanguinário surge um amigo dos mártires e dos divinos. Eia! Basta! Já se derramou muito sangue cristão, como se fosse pouco dizer sangue humano! Basta de os homens se deixarem tomar por essa loucura de destruições mútuas! Dê-se agora um basta de fazer oferendas às fúrias e ao Orco! Basta o que há muito divirte os olhos dos turcos! Depois de tolerar as misérias das guerras por tanto tempo, arrependei-vos ao menos uma vez! Que sejam imputados aos fados as insanidades todas praticadas até hoje. Que os cristãos não se envergonhem em fazer como outrora os pagãos: esquecer os males passados. Depois, por deliberações comuns, aplicai-vos à preservação da paz. E aplicai-vos de tal forma que ela se firme com laços não de tecido, mas sólidos e mais inquebráveis que o diamante, que jamais romper-se-ão.

Apelo a vós, príncipes, que com um mínimo gesto alteram a sorte dos mortais, vós que representais entre os homens o exemplo do Cristo Príncipe. Reconhecei a voz do vosso Mestre, que vos chama à paz. Convencei-vos de que o mundo todo, fatigado de demasiados males, suplica isso de vós. Se há alguém a quem uma ofensa ainda machuque, parece justo que a 
Si quid cui dolet etiam, aequum est hoc publicae omnium felicitati donare. Maius est negotium, quam ut levibus causis debeat retardari. Appello vos, sacerdotes deo sacri: hoc studiis omnibus exprimite, quod deo gratissimum esse scitis. Hoc depellite, quod illi maxime invisum. Appello vos, theologi: pacis evangelium praedicate, hanc semper popularibus auribus occinite. [880] Appello vos episcopi aliique dignitate Ecclesiastica praeminentes: ad pacem aeternis vinculis adstringendam vestra valeat auctoritas. Appello vos, primates et magistratus, ut sapientiae regum, ut pietati pontificum vestra voluntas sit adiutrix. Vos appello promiscue, quicumque Christiano nomine censemini, consentientibus animis in hoc conspirate. Hic ostendite quantum valeat adversus potentum [885] tyrannidem multitudinis concordia. Huc pariter omnes omnia sua consilia conferant. Iungat aeterna concordia, quos tam multis rebus coniunxit natura, pluribus Christus. Communibus studiis agant omnes, quod ad omnium ex aequo felicitatem pertinet.

[889] Huc invitant omnia, primum ipse naturae sensus, atque ipsa, ut ita dicam, humanitas. [890] Deinde totius humanae felicitatis Princeps et Auctor Christus. Ad haec tam multa pacis perdoe em nome da felicidade pública de todos. Este assunto é da maior prioridade para ser protelado por motivos insignificantes. Apelo a vós, sacerdotes consagrados para Deus. Empenhai-vos zelosamente em pregar aquilo que sabeis que é a coisa mais grata a Deus e em dissuadir daquilo que Ele mais detesta. Apelo a vós, teólogos. Pregai o Evangelho da paz, trombeteai sempre isto nos ouvidos do povo. Apelo a vós, bispos e demais dignatários eclesiásticos, que a vossa autoridade sirva para atar a paz com vínculos eternos. Apelo a vós, nobres e magistrados, para que auxilies com a vossa vontade a sabedoria dos reis e a piedade do pontífice. Apelo a todos vós, quem quer que sejais, que vos designeis com o nome de cristão, para que vos coloqueis de acordo e sejais unânimes no projeto da paz. Mostrai aqui que a concórdia dos povos vale mais que tirania dos poderosos. Que todos ofereçam por igual todos os seus conselhos para essa finalidade. Que a concórdia eterna una aqueles a quem a natureza uniu por muitos vínculos, mas que Cristo uniu por muitos mais. Que todos, em suas atividades cotidianas, procurem o que por igual interessa à felicidade de todos.

Tudo nos convida a isso. Em primeiro lugar, o próprio instinto da natureza, e, se assim posso dizer, a própria humanidade. Em segundo lugar, o próprio Cristo, príncipe e autor de toda felicidade humana. Depois, as incontáveis vantagens da paz, contrastadas com o número 
commoda, tot belli calamitates. Vocant huc ipsi principum animi, iam velut adflante deo, ad concordiam propensi. En pacificus ille placidusque Leo, signum omnibus extulit, ad pacem invitans, vereque Christi vicarium agens. $\mathrm{Si}$ vere oves estis, sequimini pastorem. Si filii, audite patrem. Vocat huc [895] ille non titulo tantum Christianissimus Galliarum rex Franciscus, qui pacem nec emere gravatur, nec usquam suae maiestatis habet rationem, modo publicae paci consulat: hoc denique vere splendidum ac regium esse docens, de genere humano quam optime mereri. Vocat huc clarissimus princeps Carolus, incorruptae indolis adolescens. Nec abhorret Caesar Maximilianus, nec detractat [900] inclytus Angliae rex Henricus. Tantorum principum exemplum, caeteros libenter imitari par est. Maxima plebis pars bellum detestatur, pacem orat. Pauculi quidam modo, quorum impia felicitas a publica pendet infelicitate, bellum optant. Quorum improbitas, ut plus valeat, quam imenso das calamidades da guerra. Convidam à paz até mesmo as inclinações dos príncipes que, como que inspirados por Deus, já estão propensos à concórdia. Eis aquele pacífico e tranquilo Leão ${ }^{142}$, que, diante de todos, ergueu o estandarte a fim de convidar à paz e agiu como autêntico Vigário de Cristo. Se verdadeiramente sois ovelhas, segui o pastor. Se sois filhos, escutai o pai. Convida à paz o celebrado Francisco $^{143}$, rei da França, cristianíssimo não apenas de título, o qual não só não se envergonha de comprar a paz, como também não se mostra demasiadamente zeloso de sua majestade, contanto que seja para cuidar da paz pública, ensinando enfim que é próprio de um espírito realmente esplêndido e régio ser merecedor da maior gratidão do gênero humano. Convida à paz o preclaríssimo Príncipe Carlos, ${ }^{144}$ jovem de índole incorruptível. E não descuida de mim o Imperador Maximiliano, ${ }^{145}$ assim como não deprecia Henrique, o ínclito rei da Inglaterra. ${ }^{146}$ É justo que os demais imitem com toda alegria o exemplo de tão grandes príncipes. O povo em sua maioria detesta a guerra e faz votos pela paz. Reduzido é o número idade por ocasião da publicação da Querela. Carlos só assumiria o Império Habsburgo em 1519.

${ }^{145}$ Maximiliano I (1459-1519) contava apenas 18 anos na época da publicação do Querela, morreria dois anos depois.

${ }^{146}$ Henrique VIII (1491-1547), Rei da Inglaterra de 1509 até a sua morte. Erasmo elogia a catolicidade do rei inglês porque este seria excomungado somente em 1533 e romperia com Roma em 1536.
} 
bonorum omnium voluntas, aequum sit nec ne, vos ipsi expendite. Videtis hactenus, nihil actum foederibus, nihil [905] promotum affinitatibus, nihil vi, nihil ulciscendo. Nunc contra periculum facite, quid possit placabilitas, quid beneficentia. Bellum e bello seritur, ultio trahit ultionem. Nunc gratia gratiam pariat, et beneficium beneficio invitetur, isque regalior videatur, qui plus de suo iure concesserit. Non successit quod humanis studiis gestum est. At fortunabit ipse Christus pia consilia, quae se [910] autore et auspice viderit suscipi. Aderit dexter, adspirabit, favebitque faventibus ei rei, cui favit ipse plurimum, privatos adfectus publica vincat utilitas. Quamquam dum huic consulitur, et sua cuique fortuna melior reddetur, principibus regnum erit augustius, si piis ac felicibus imperent, ut legibus regnent magis quam armis; proceribus maior veriorque dignitas, sacerdotibus otium tranquillius: [915] populo quies uberior, et ubertas quietior: nomen Christianum formidabilius crucis hostibus. Denique singuli singulis, et omnes omnibus cari simul [917] et iucundi eritis, super omnia Christo grati, cui placuisse summa felicitas est. [918] Dixi. daqueles que optam pela guerra, porque sua felicidade ímpia depende da infelicidade pública. Ponderai vós mesmos se é justo que a maldade destes tenha mais força do que a vontade de todos os homens bons. Vedes que até o presente momento nada se conseguiu com tratados, nada foi feito com a promoção de matrimônios políticos, nada se obteve pela força, nada se construiu com a vingança. Fazei então a experiência do poder da clemência e da boa vontade. Guerra semeia guerra, vingança atrai vingança. Que, agora, a indulgência dê à luz a indulgência e um favor feito a alguém convide a outro favor. Que se avalie como possuidor de realeza aquele que mais conceder os seus próprios direitos em benefício da paz. Não se realizou aquilo que foi tentado apenas com as providências humanas, mas o próprio Cristo trará êxito às decisões piedosas que vir que são concebidas tendo-o como autor e guia supremo. Estará presente de forma propícia, inspirará e favorecerá aqueles que favorecem aquilo a que ele favoreceu sobremaneira. Que a utilidade pública supere as paixões privadas. Até porque, enquanto cada um se ocupa desta, torna melhor sua própria sorte: os príncipes serão mais augustos se governarem súditos piedosos e felizes, reinando sob a égide das leis mais do que pelas armas. Os nobres gozarão de maior e mais autêntica dignidade; os sacerdotes usufruirão de um repouso mais tranquilo; o povo terá uma tranquilidade mais próspera, ou uma 
prosperidade mais tranquila. O nome cristão será mais temido pelos inimigos da cruz. Em suma, todos e cada um de vós sereis em tudo mais amados e agradáveis uns para os outros e cada um de todos e, sobretudo, sereis mais gratos a Cristo, a quem agradar consiste a suma felicidade dessa vida. Tenho dito. 


\section{BIBLIOGRAFIA}

\section{Fontes primárias}

DESIDERII ERASMI ROTERODAMI OPERA OMNIA. recognita et adnotatione critica instructa notisque illustrata. Amsterdam: North-Holland, 1969-2001.

. Antibarbarorum. I-1. Amsterdam: North-Holland, 1969.

De pueris. I-2. Amsterdam: North-Holland, 1971.

. Querela Pacis. IV-2. Amsterdam: North-Holland, 1977.

DESIDERIUS ERASMUS. Opus Epistolarum Desiderii Erasmi Roterodami. Ed. H. M. Allen. Oxford: Oxford University Press, 1906-1958 (12 volumes).

. The correspondence of Erasmus. Letters 446 to 593. Trad. R. Mynors e D. Thompson. Toronto/Buffalo: Toronto University Press, 1977.

\section{Traduções da Queixa da Paz em ordem cronológica}

La "Querela Pacis" d'Erasme. Thèse de doctorat présentée à la Faculté des Lettres de l'Université de Fribourg. Elise Constantinescu Bagdat. Les presses Universitaires de France, 1924.

Klage des Friedens. Übertragung und Nachwort von Arthur von Arx. Herausgegeben von Hans-Urs von Balthasar. BaseL: Published by Schwabe, Klosterberg, 1945.

Contro la guerra: Querela Pacis, Dulce bellum inexpertis. Tradução por Franco Gaeta. L. U. Japadre, 1968.

Dialogus, Julius Exclusus e Coelis. Julius vor der verschlossenen Himmelstür, ein Dialog. Institutio Principis Christiani. Die Erziehung des christlichen Fürsten. Querela Pacis. Die Klage des Friedens. Übersetzt, eingeleitet und mit Anmerkungen versehen von Gertraud Christian. Lateinisch und deutsch. Darmstadt, Wissenschaftliche 
Buchgesellschaft, 1968. Ausgabe in 8 Bänden. Herausgegeben von Werner Welzig. Band 5).

Ein Klag des Frydens: Leo Juds Übersetzung der Querela Pacis von 1521 zusammen mit dem lateinischen Original, Nobile Turegum, Zürcher Drucke des 16. bis 19. Jahrhunderts herausgegeben von Martin Bircher. eds. Alois M. Haas; Urs Herzog. Zürich: Orell Füssli Verlag, 1969.

La Complainte de la Paix. Tradution de le Chevalier de Berquin. Notes, commentaires et appendices par Emile v. Telle. Paris-Genève: Librairie Droz, 1978.

Die Klage des Friedens. Erasmus von Rotterdam. Hrsg. u. übers. von Brigitte Hannemann. München/Zürich: Piper, 1985.

De klacht van de vrede, die overal door alle volken verstoten en versmaad wordt. druk 2. T. Van Leeuwen. Publisher: Donker, 1986.

Collected works of Erasmus. Litterary and educational writings 5.Panegyrucus/Moria/Julius Exclusus/InstitutioPrincipis Christiani/Querela Pacis. A. H. T. Levi (ed.). Toronto/Buffalo/London: University od Toronto Press, 1986.

La "Querela Pacis" d'Érasme, 1517. Translated, with an introduction and bibliography by Élise Constantinescu Bagdat. Constantinescu Bagdat (Ed.).Etudes d'histoire pacifiste.vol. 1.1987.

Oeuvres Choisies. Présentation, traduction et annotations de Jacques Chomarat. Paris: Librairie Génerale Française, 1991.

Érasme. Éloge de la folie. Adages. Colloques. Réflexions sur l'Art, l'Éducation, la Religion, la guerre, la Philosophie. Correspondance. Édition établie par Claude Blum, André Godin, Jean-Claude Margolin et Daniel Ménager. Paris : Éditions Robert Laffont, 1992.

Il lamento della pace. Trad. Carlo Carena. Testo latino a fronte. Collana n.199. Torino: Einaudi, 1995.

Die Klage des Friedens. Übersetzung von Brigitte Hannemann, Zürich 1998.

A guerra e a queixa da paz. Trad. Guimarães Pinto. Lisboa: Edições 70, 1999.

Die Klage des Friedens. Übertagen von kurt Steinmann. Insel, 2001.

The Complaint of Peace. Cosimo Classics, 2004.

Il lamento della pace. Testo latino a fronte. Trad. Federico Cinti, con un saggio di JeanClaude Margolin. Milano: Collana Classici del Pensiero, 2005.

Plaidoyer pour la paix. Série Poche-Retour aux grands textes. Chantal Labre (Scenario). Éditeur: Arléa, 2005.

Sulla Pace. Perle di saggezza. Keybook, 2007

Contro la Guerra. M. Jevolella (a cura di). Milano: Mondadori, 2008. 
Adagios del poder y de la Guerra y Teoría del adagio. Edición, traducción y notas de Ramón Puig de la Bellacasa. Madrid: Alianza Editorial, 2008.

Complaint of Peace. Cornell: Cornell University Library, 2009.

Complaint of Peace. Dodo Press, 2009.

The Complaint of Peace. BiblioBazaar. 2009.

Against War. The Floating Press, 2012. 2013 - Die Querela Pacis des Erasmus von Rotterdam - der Pazifismus in seiner Entstehung und politisch-historischen Auswirkung Taschenbuch. Tradução por Andre Hoffmann. 2013.

The Complaint of Peace. Translated from the Querela Pacis (A.D. 1521) - Primary Source Edition. Nabu Press, 2014.

\section{Outras fontes e traduções}

AELIUS THEON. The exercices of Aelius Theon. In: Progymnasmata. Greek Textbooks of Prose Composition and Rhetoric. Trad. George Kennedy. Leiden/Boston: Brill, 2003.

ARISTÓTELES. On rhetoric: a theory of civic discourse. Trad. George Kennedy. Billingual version (English/Greek). New York: Oxford University Press, 2007.

Poetics. Vol. XXIII. Loeb Classical Library, 199.Trad. Stephen Halliwell. Bilingual version (English/Greek). Cambridge/London: Harvard University Press, 1995.

ERASMO DE ROTTERDAM. Contro la guerra (Querela Pacis, Dulce bellum inexpertis). Milano: L. U. Japadre. 1968.

. Diálogo cujo título é O Ciceroniano, ou acerca do melhor gênero de discurso. Tradução, introdução e notas de Elaine C. Sartorelli. São Paulo: Editora Unesp, 2013.

Recursos de forma y de contenido para enriquecer un discurso. De copia verborum ac rerum. Introducción, traducción y notas de Eustaquio Sánchez Salor. Madrid: Cátedra, 2011.

. O Elogio da Loucura. Tradução, introdução e notas de Elaine C. Sartorelli. São Paulo: Editora Hedra, 2013.

. Opus Epistolarum Des. Erasmi Roterodami. Allen, P. S., ed. Oxford: Oxford Universiy Press, 1906.

The Collected Works of Erasmus. Letters 1 to 41. 1484-1500. Tomo I. Toronto: University of Toronto, 1974. 
. On copia of words and ideas. De utraque Verborum ac Rerum Copia Trad. Donald King e David Rix. Medieaeval Philosophical Texts in Translation. Milwaukee: Marquette University Press, 2007.

. The 'Julius exclusus' of Erasmus.Trad, p. Pascal. Billingual version (English/Latin). Bloomington: Indiana University Press, 1968.

CICERO. Orator. Libri I-II. Trad. E. W. Sutton completed with an introduction by R. Rackham. Loeb Classical Library, 348.Billingual version (English/Latin). Cambrige/London: Havard University Press, 1942.

[CICERO]. Rhetorica ad Herennium. Vol I. Loeb classical library, 403. Bilingual version (English/Latin). Cambridge/London: Harvard University Press, 2011.

ISOCRATES. Sur la Paix. In : Isocrate, Discours - Sur la Paix, Aréopagitique, Sur l'Échange - Texte établi et trad. par Georges Mathieu, Tome III, Collection des Universités de France, Paris: Les Belles Lettres, 2003.

PSEUDO-ARISTOTE. Rhétorique à Alexandre (text établi et traduit par Pierre Chiron). Paris : Les Belles Letres, 2002.

QUINTILIANUS. The Orator's Education. Institutio oratoria Libri I-II.Vol I. Loeb classical library, 124. Trad. Donald A. Russel. Billingual version (English/Latin). Cambridge/London: Harvard University Press, 2006.

. La formazione dell'oratore (volume primo - libri I-IV; introduzione di Michael Winterbottom, traduzione e note di Stefano Corsi). Milano: Biblioteca Universale Rizzoli, 1997.

. La formazione dell'oratore (volume primo - libri V-VIII; traduzione e note di Cesare Marco Calcante e Stefano Corsi). Milano: Biblioteca Universale Rizzoli, 1997.

. La formazione dell'oratore (volume primo - libri IX-XII; traduzione e note di Cesare Marco Calcante e Stefano Corsi). Milano: Biblioteca Universale Rizzoli, 1997.

. The Lesser Declamations. Declamationes.Vol I. Loeb classical library, 500.Trad. Shackleton Bailey. Bilingual version (English/Latin). Cambridge/London: Harvard University Press, 2006.

. The Lesser Declamations. Declamationes. Vol II. Loeb classical library, 501.Trad. Shackleton Bailey. Bilingual version (English/Latin). Cambridge/London: Harvard University Press, 2006.

SENECA THE ELDER. Declamations: Controuersiae, Books I-VI. Vol. I. Loeb classical library, 463.Trad. Michael Winterbottom. Bilingual version (English/Latin). Cambridge/London: Harvard University Press, 1974. 
. Declamations: Controuersiae, Books VII-X. Suasoriae, Fragments. Vol. II. Loeb classical library, 464.Trad. Michael Winterbottom. Bilingual version (English/Latin). Cambridge/London: Harvard University Press, 1974.

SENECA. Moral Essays: De Providentia. De Constantia. De Ira. De Clamentia. Vol. I. Loeb classical library, 214.Trad. John W. Basore. Bilingual version (English/Latin). Cambridge/London: Harvard University Press, 1928.

TACITUS. Dialogue on Oratory. Vol. I. Loeb classical library, 35.Trad. M. Hutton e W. Peterson. Bilingual version English/Latin).Cambridge/London: Harvard University Press, 1914.

THOMAS MORE. Translations of Lucian, ed. CR. Thompson, New Haven and London, 1974

\section{Dicionários}

BAILLY, Anatole, Le Grand Dictionnaire Grec-Français, Paris: Hachette, 2000

GAFFIOT, F. Latin Dictionnaire Latin-Français. Paris: Hachette, 2000.

\section{Estudos}

ACHARD, Guy. Introduction. In: Rhetorica ad Herennium [Rhéthorique à Herrenius, trad. fr. Guy Achard, Paris: Les Belles Lettres, 1997.

AKKERMAN, Fokke. Rudolf Agricola, een humanistenleven. In: AKKERMAN, F. Met iets van eeuwigheid.Groningen: Rijksuniversiteit Groningen, 1995.p. 67-79.

ALEXANDRE JÚNIOR, Manuel. Eficácia Retórica: A palavra e a imagem. Revista Rhetorike. Centro de Estudos Clássicos, Faculdade de Letras da Universidade de Lisboa. 2008, p. 1-26.

AYGON, Jean-Pierre. Le dialogue comme genre dans la rhétorique antique. Pallas, 2002, n. 59, p. 197-208.

BAGDAT, Élise Constantinescu. Études d'histoire pacifiste...: La "Querela Pacis" d'Erasme (1517). La plainte de la paix. V. 2. De Vauban. Les Presses universitaires de France, 1924.

BAILEY, Schackleton. More on Pseudo-Quintilian's Longer Declamations. Harvard Studies in Classical Philology. Vol. 88, 1984, p. 113-137.

. More on Quintilian's Shorter Declamations. Harvard Studies in Classical Philology. Vol. 92, 1989, p. 367-404. 
BATAILLON, Marcel. Erasmo y España. Estudios sobre la historia espiritual del siglo XVI. México Distrito Federal.: Universidad de México. 1982.

. Erasmo y el erasmismo. 1 ed. Barcelona: Editorial Crítica, 1977.

BAUMANN, Uwe. Thomas More and the Classical Tyrant. Moreana, n. 86, 1985.

BEAUDUIN, Édouard. Memórias de Erasmo. Rio de Janeiro: Paz e terra, 1991.

BEJCZY, István. Erasmus and the Middle Ages. The historical consciousness of a Christian humanist. (Brill's studies in intellectual history) Leiden/Boston/Köln: Brill, 2001.

BENTLEY, Jerry H. Biblical Philology and Christian Humanism: Lorenzo Valla and Erasmus as Scholars of the Gospels. The Sixteenth Century Journal. Vol. 8, No. 2. (Humanism in the Early Sixteenth Century), 1977, p. 8-28.

BERNSTEIN, Neil W. Adoptees and Exposed Children in Roman Declamation: Commodification, Luxury, and the Threat of Violence. Classical Philology. Vol. 104, No. 3. 2009, p. 331-353.

BIETENHOLZ, Peter Gerard; DEUTSCHER, Thomas Brian. Contemporaries of Erasmo. A biographical Register of the Renaissance and Reformation. Vol. 1-3. Toronto: University of Toronto Press. 1985.

. Encounters with a Radical Erasmus. Erasmus' Work as a Source od Radical Thought in Early Moderns Europe. (Erasmus Studies) Toronto/Buffalo/London: University of Toronto Press, 2009.

BIFFINO, Galimberti. Un cliché rovesciato. L'Encomium Neronis di Gerolamo cardano. in: CASTAGNA, L; VOGT-SPIRA, G.; BIFFINO, G. Pervertere: Ästhetik der Verkehrung: Literatur und Kultur nerronischer Zeit und ihre Rezeption. München. 2002, p. 253-258.

BLOOMER, Martin. Roman declamation: the elder Seneca and Quintilian. In: BLOOMER, Martin. (ed.). A Companion to Roman Rhetoric. Oxford: Blackwell, 2010.

. Review (La fiction des déclamation). The Journal of Roman Studies. Vol. 99, 2009, p. 267-268.

BOEFT, Jan den. Erasmus en het humanisme. Eeuwwenden. Omvang. Bron. 1989 p. 35-54.

BOYLE. Marjorie O. A Conversational Opener: The Rhetorical Paradigm of John 1:1. JOST, Walter; OLMESDET, Wendy (ed.) A companion to Rhetoric and Rhetorical Cristicism. Oxford: Blackwell Publishing, 2004, p. 58-79. 
BONNER, Stanley Frederick. Roman Declamation in the Late Republic and Early Empire. Liverpool: Oxford University Press, 1949.

BOULET, Michel. Les avatars de la déclamation à la Renaissance. Tese de Doutorado. École doctorale Arts, Lettres, Langues, Philosophie, Communication. Toulouse, 2013.

BOWERSOCK, G. W. Introduction. In: LORENZO VALLA. On the Donation of Constantin. Cambridge: Havard University Press, 2008, i-xiv.

BURKE, Peter. Uma História Social do Conhecimento: De Gutenberg a Diderot. Rio de Janeiro: Jorge Zahar, 2003.

CAILES. Michael John. Renaissance ideas of peace and war, and the humanist challenge to the scholastic just war: The disputatio de pace et bello of 1468: Erasmus and Machiavelli. Doctoral thesis. University of Exeter. 2012.

CANTOS, Jorge. Erasmo de Rotterdamo e a pedagogia da sátira. Tese de Doutoramento em Filosofia. Orientação Carlos Kfouri Quartim de Moraes. Campinas: Universidade Estadual de Campinas, 2006.

CHOMARAT, Jacques. Grammaire et rhétorique chez Érasme. V. 2. Paris : Belles Léttres, 1981.

. Un ennemi de la guerre : Érasme. Bulletin de l'Association Guillaume Budé: Lettres d'humanité. Vol. 33, 4, 1974, p. 445-465.

CHRISTI, Oliver. Die Friedensidee des Erasmus von Rotterdam. Berlin: 2009.

CLARK, Donald Lemen. Rhetoric in Greco-Roman Education. Nova York: Columbia University Press, 1957.

CLARKE. Martin Lowther. Rethoric at Rome: a historical survey. Declamation. London/New York: 1996, p. 86-99.

COLLEMAN, Christopher B. Introduction. In: Lorenzo Valla, Discourse on the Forgery of the Alleged Donation of Constantine in Latin and English English translation by Christopher B. Coleman (Proofread by Jonathan Perry, February 2001). New Haven: Yale University Press, 1922.

CORBETT, Edward; CONNORS, Robert. Classical Rhetoric for the Modern Student. 4 ed. New York/Oxford: Oxford University Press, 1999.

CONNOLLY, Joy. The Politics of rhetorical education. in: The Cambridge Companion to Ancient Rhetoric. GUNDERSON, Erik. (ed.). Cambridge: Cambridge University Press, 2009, p. 126-144. 
CONTE, Gian Biaggio. Latin Literature: A History. Trad. J. B. Solodow. Baltimore: Joehns Hopkins University Press, 1999.

COPPENS, Chris ET ALLIA. Erasmiana Lovaniensia. Catalogus van de Erasmustentoonstelling in de Centrale Bibliotheek te Leuven. november-december 1986. Leuven University Press, 1986.

CORRAL, Hernán. Tyranny and Law in Thomas More's Declamation in Reply to Lucian's Tyrannicide. Moreana. 2012, vol. 49, nº189-190, p. 71-88.

COSTRINO, Artur. A lição dos declamadores: Sêneca, o rétor, e as suas suasórias. Tese de Mestrado em Letras Clássicas. São Paulo: Universidade de São Paulo. 2010.

COUSINS, A. D. Humanism, Female Education, and Myth: Erasmus, Vives, and More's “To Candidus". Journal of the History of Ideas. Vol. 65, No. 2, 2004, p. 213-230.

DUNGEN, Peter van den. Erasmus: 16th Century Pioneer of Peace Education and a Culture of Peace. International Peace Research Association (IPRA) Conference (Peace History Commission).University of Leuven, 2008.

DUPONT, Florence. Recitatio and the reorganization of the space of puclic discourse. In:HABINEK, Thomas. SCHIESARO, Alessandro. The Roman Cultural Revolution. Cambridge: Cambridge University Press, 1997, p. 44-59.

EDWARD, William. Seneca the Elder: Suasoriae. Bristol: Bristol Classical Press, 1928.

ENOS, Richard Leo. Quintilian's influence on the teaching of speaking and writing in the Middle Ages and Renaissance (1990). in: MURPHY, James (ed.). Latin Rhetoric and Education in the Middle Ages and Renassance. Aldeshot: Ashgate Publishing Limited, 2005, p. 158-183.

FAIRWEATHER, Janet. Seneca the Elder.Cambridge: Cambridge University Press, 1981.

FOX, Alistai. Thomas More: History and Providence. New Haven/London: Yale University Press, 1983.

GAETA, Franco. Introduzione. In: ERASMO DE ROTTERDAM. Contro la guerra (Querela Pacis, Dulce bellum inexpertis). L. U. Japadre. 1968.

GEORGE, Edward. Introduction. in JUAN LUIS VIVES. Declamationes Sullanae. EnglishLatin. Edited and translated with an introduction by Edward V. Georde. (Selected works of J. L. Vives. V. 2). Leiden: Koninklijke Brill, 2012.

GIANOTTI, Gian Franco. Utriusque linguae doctissimus: Erasmo e La storia degli studi classici. in: Erasmo da Rotterdam e la cultura europea. Atti dell'Incontro di Studi nel V centenario della laurea di Erasmo all'Università di Torino (Torino, 8-9 settembre 
2006). Enrico Pasini e Pietro Rossi (ed.) Firenze: Edizioni Del Galluzzo, 2008, p. 61121.

GIAZZI, E.V. Coluccio Salutati e il rilancio del genere della Declamatio. Coluccio Salutati e l'invenzione dell'Umanesimo. Firenze, 2008, p. 315-339.

GIBSON, Craig A. Learning Greek History in the Ancient Classroom: The Evidence of the Treatises on Progymnasmata. Classical Philology. Vol. 99, No. 2, 2004, p. 103-129.

GINZBURG, Carlo. Préface. In: LORENZO VALLA. La donation de Constantin. Sur la donation de Constatin à lui faussement attribuée et mensongère. Trad. Jean-Baptiste Giard. Paris: Les Belles Lettres, 2004.

GODARD, Anne. Le dialogue à La Renaissance. Paris: Puf, 2001.

GÓMEZ, Jorge. El lugar del diálogo en el sistema literario clasicista: después de 1530. Etiópicas. 11 (2015) I, p. 39-68.

GÓMEZ CERVANTES, María del mar. El ziguezagueante y dilatado recorrido de la Retórica : un acercamiento a su cambiante valorización. Interlinguística. N. 17. 2007, p. 419-428.

GRAFTON, Anthony; MOST, Glenn W. ; SETTI, Salvatore (ed). The Classical Tradition. Havard: Havard College, 2010. Voz : Senece the Elder, p. 872-874.

GRAFTON, Anthony. Cardano's Cosmos: The Worlds and Works of a Renaissance Astrologer. Cambridge: Havard University Press, 1999.

GREEN, Lawrence D.; MURPHY, James Jerome. Renaissance Rhetoric. Short-Title Catalogue 1460-1700. 2 ed. Aldershot/Burlington: Ashgate, 2006.

GRIMAL, P. La littérature latine. Paris: Fayard, 1994.

GRUBER, Heather Irene Waddell. The Women of Greek Declamation and The Reception of Comics Stereotypes. Thesis in Doctor Philosophy. University of Iowa. 2008.

GUNDERSON, Erik. Declamation, Paternity, and Roman Identity. Authority and the Rhetorical Self. Cambridge: Cambridge University Press, 2003.

HASKINS, Charles Homer. The Renaissance of the Twelfth Century. New York: Meridian Books, 1957.

HERDINGER, O. Einleitung. Querela Pacis. In: Desiderii Erasmi Opera Omnia. Recognita et adnotatione critica instructa notisque illustrata. IV-2. Amsterdam: North-Holland, 1977, p. 1-56.

HERNÁNDEZ GUERRERO, J. A.; GARCÍA TEJERA, M. C. Historia breve de la Retórica. Madrid: Síntesis, 1992. 
HOFFMANN, Andreas. Die Querela Pacis des Erasmus von Rotterdam - der Pazifismus in seiner Entstehung und politisch-historischen Auswirkung.Norderstedt: Grin-Verlag. 2000 .

HOFFMANN, Manfred. Rhetoric and Theology. The Hermeneutic of Erasmus.Toronto/London/Buffalo: University of Toronto Press, 1994.

KENNEDY, George A. A new history of classical rhetoric. Princenton: Princeton University Press, 1994.

. Classical Rhetoric and Its Christian and Secular Tradition from Ancient to Modern Times. Chapel Hill: University of North Carolina Press, 1980.

. Greek rhetoric under Christian emperors. Princeton: Princento University Press, 1983.

KINNEYY, Arthur F. Continental Poetics. In: JOST, Walter; OLMSTED, Wendy. A companion to rhetoric and rhetorical criticism. Oxford: Blackell, 2004.

KINSELLA, David; CARR, Craig Car (eds.). The Morality of War. London: Lynne Rienner Publishers, 2007.

KNOTT, Betty. Introduction. De dvplici copia verborvm ac rervm commentarii dvo. In: Desiderii Erasmi Opera Omnia. I-6. Amsterdam: North-Holland, 1988, p. 7-20.

LABRE, Chantal. Présentation: Playdoyer pour la Paix par Érasme. Traduit du Latin. Coll. Retour aux Grands Textes: Domaine Latin. Paris, 2002.

LÉVY, C. Cicero academicus: recherches sur les 'Academiques' et sur la philosophie cicéronienne. Roma: École Française de Rome, 1992.

LEUSHUIS, Reinier. The Mimesis of Marriage: Dialogue and Intimacy in Erasmus's Matrimonial Writings. Renaissance Quarterly. Vol. 57, No. 4, 2004, p. 1278-1307.

LIMA, Sidney C. Aspectos do gênero dialógico no De finibus, de Cícero [it includes a translation and a study of De finibus. Tese de doutorado. Campinas, IEL/UNICAMP, 2009.

LOGAN, George; ADAMS, Robert. Introduction. In: TOMAS MORE. Utopia. Cambridge: Cambridge University Press, 2003.

. Utopia and deliberative rhetoric. Moreana. Vol. 31. 118-119. June. 1994, p. 103-120.

MACK, Peter. Renaissance Argument.Valla and Agricola in the Traditions of Rhetoric and Dialectic. Leiden/New York/Köln: Brill., 1993, p. 227-243.

. A History of Renaissance Rhetoric. 1380 - 1620. Oxford: Oxford UP, 2011. 
Humanist rhetoric and dialect. in: KRAYE, Jilll. The Cambridge Companion to Renaissance humanism. Cambridge/New York/Melbourne: Cambridge University Press. 1996, p. 82-99.

MAGNIEN, Michel. Presence de l'Art poetique d'Horace dans les adage d'Érasme. Camenae. N. 13. 2012, p. 1-20.

MANJARRÉS, Julio Mangas. Séneca e el poder de la cultura. Madrid: Editorial Debate, 2001.

MANOEL, Rodrigo Garcia. Teoria e Prática: estudo e tradução das epístolas e invectivas de Pseudo-Salústio e Pseudo-Cícero à luz dos progymnásmata. Tese de Mestrado. Orientação João Ângelo Oliva Neto. São Paulo: Faculdade de Filosofia, Letras e Ciências Humanas. Departamento de Letras Clássicas e Vernáculas, 2014.

MANSFELD, Bruce E. Erasmus in the Nineteenth Century: The Liberal Tradition. Studies in the Renaissance. Vol. 15. 1968, p. 193-219.

MAYER, Roland. "The Earlier Impire: AD 14-68". in: HARISSON, Stephen (org.). A companion to Latin literature. Oxford: Blackwell, 2005, p. 61.

MARGOLIN, Jean Claude. Bibliographie Érasmienne IV: cinq anées de bibliographie erasmienne (1971-1975). De Petrarque a Descartes. Paris: Vrin, 1997.

. Érasme dans son Miroir et dans son Sillage. Variorum Collected Studies. Paris: Variorum, 1987.

. Érasme. Précepteur de l'Europe. Paris: Julliard, 1995.

Erasmus (1467?-1536). Prospects: the quarterly review of comparative education. Paris. UNESCO.International Bureau of Education.vol. XXIII, no 1/2, 1993, p. 333352.

. Érasme: le prix des mots et de l'homme. Collected Studies. Vol. 241. London: Ashgate, 1987.

. Érasme. Ecrivains de toujours. Paris: Seuil, 1977.

La complainte de la paxi (Querela Pacis). In : ÉRASME. La complainte de la paxi (Querela Pacis). Trad. Jean-Claude Margolin. Paris: Robert Lafont, 1992.

. Guerre et paix dans la pensée d'Érasme, textes choisis et présentés par Jean-Claude Margolin. Paris, Aubier-Montaigne, 1973.

. Neuf années de bibliographie érasmienne, 1962-1970, Paris: Vrin, 1977.

. Philosophies de la Renaissance. Seire L'Atelier de la Renaissance. N. 7, Paris: Pradigme, 1998. 
. Introduction. De conscribendis epistolis. Opera Omnia Desiderii Erasmi. I-2. Amsterdam : North-Holland Publishing Company, 1971, p. 153-581.

MARROU, Henri-Irenée. Histoire de l'éducation dans l'antiquité. Paris: Seuil, 1948.

MARTÍN, Javier de Lucas; CHORNET, Consuelo Ramón. Querela Pacis, perpetua? Una reivindicación del Derecho Internacional. Valencia: Publicaciones de la Universidad de Valencia, 2007.

MINNICH, Nelson H.; MEISSNER, W. W. The Character of Erasmus. The American Historical Review, Vol. 83, No. 3, 1978, p. 598-624.

MÉNAGER, Daniel. Érasme, les intellectuels et l'affaire Reuchlin. Renaissance and Reformation/Renaissance et Réforme. XXIV. 4. 2000, p. 49-63.

MENDELSON, Michael. Declamation, Context, and Controuersiality.Rhetoric Review, Vol. 12, No. 1. 1994, p. 92.107.

MEULEN, Jacob ter. From Erasmus to Tolstoy: The Peace Literature of Four Centuries Jacob ter Meulen's Bibliographies of the Peace Movement before 1899. 1 ed. Greenwood: Bibliographies and Indexes in Law and Political Science, 1990. 168 p.

MILLER, Clarence. Style and Meaning in More's Utopia: Hythloday's Sentences and Diction. Acta Conventus Neo-Latini Hafniensis: Proceeding of the Eigth International Congress of Neo-Latin Studies. Ed. Rhoda Scnur et al. Medieval and Renaissance Texts and Studies. Vol. 120. Binghampton. New York: Center for Medieval and Early Renaissance Studies, 1994, p. 675-683

MOYA BEDOYA, Juan Diego. En torno de Desiderio Erasmo y de Laus Stultitiae. Praxis. 62. 2008, p. 191-227.

MURPHY, James Jerome. Latin Rhetoric and Education in the Middle Ages and Renaissance. Aldeshot/Burligton: Ashgate Publishing, 2005.

. One Thousand Neglected Authors: The Scope and Importance od Renaissance Rhetoric. 1983, p. 20-36.

. Renaissance Eloquence: Studies in the Theory and Practice of Renaissance Rhetoric. Berkeley: University of California Press, 1983.

. Rhetoric in the Fifteenth-Century: From Manuscript to Print. in: Rhetoric and Renewal on the Latin West 1100-1540. MEWS, Constant; NEDERMAN, Cary; THOMSON, Rodney. (Ed.) Turnhout (Bélgica): Brepols Publishers, 2003, p. 227-242.

Rhetoric in the Middle Ages. A History of Rhetocial Theory from St. Augustine to the Renaissance. Berkely/Los Angeles: University of California Press, 1974. 
Roman Wrinting Instruction as Described by Quintilian. In: MURPHY, James Jerome (Ed.).Writing instruction.From ancient Greece to contemporary America. 3 ed. New York: Hermagoras Press, 2012, p. 36-77.

NASSARO, Sílvio Lúcio Franco. A pluralidade da verdade em Erasmo. Tese de doutorado em Filosofia. São Paulo: Universidade de São Paulo, 2010.

NELSON, Ernest W. Recent Literature Concerning Erasmus. The Journal of Modern History. Vol. 1, No. 1, 1929, p. 88-102.

PABEL, Hilmar M. Reading Jerome in the Renaissance: Erasmus' Reception of the "Adversus Jovinianum". Renaissance Quarterly, Vol. 55, No. 2, 2002, p. 470-497.

PAYNE, John B. Erasmus and Lefbvre d'Staples as Interpreters of Romans. Archiv für Reformationsgeschichte. Vol. LXV, 1974, p. 54-83.

PEREIRA, Belmiro Fernandes. As condições objectivas da praxis retórica no Dialogus de oratoribus. Comunicação. XIX Congresso da Sociedade Brasileira de Estutdos Clássicos. Julho de 2013.

PERNOT, Laurent. Rhetoric in antiquity. Trad. W. Higgins. Washington: Catholic University of America Press, 2005.

. Un rendez vous manqué. Rhetorica, 1993, XI, p. 421-437.

PIGMAN, George W. Imitation and the Renaissance sense of the past: the reception of Erasmus' Ciceronianus. The Journal of Medieval and Renaissance Studies. 9, 1979, p. $155-77$.

. Neo-Latin Imitation of the Latin Classics. Latin Poetry and the Classical Tradition: Essays in Medieval and Renaissance Literature, Oswyn Murray and Peter Godman (Ed. ) Oxford: Oxford University Press, 1990, p. 199-210.

. Versions of Imitation in the Renaissance. Renaissance Quarterly, 33 (1980), 1-32.

PINTO, Fabrina Magalhães. O discurso humanista de Erasmo: retórica da interioridade. Tese de Doutorado em História Social. Orientação: Antonio Edmilson Martins Rodrigues. Rio de Janeiro: Pontifícia Universidade Católica do Rio de Janeiro, 2006.

PHILLIPS, Margaret Mann. Erasmus in France in the Later Sixteenth Century. Journal of the Warburg and Courtauld Institutes. Vol. 34, 1971, p. 246-261.

PRETE, Sesto. Leistungen der Humanisten auf den Gebiete der lateinischen Philologie. Philologus, CIX. 1965, p. 259-69

. Observations on the History of Textual Criticism in the Medieval and Renaissance Periods. Collegeville: St. John's University Press, 1970, p. 18-27. 
REALI, Mauro; TURAZZA, Gisella. Quintiliano e l'educazione a Roma. Torino: Loescher Editore, 2012.

REMER, Gary. Dialogues of Toleration: Erasmus and Bodin. The Review of Politics, Vol. 56, No. 2, 1994, p. 305-336.

REVARD, Stella; RÄDLE, Fidel; DI CESARE, Mario. Ciceronian influences in Latin rhetorical compendia of the fifteenth century. In: MURPHY, James (ed.). Latin Rhetoric and Education in the Middle Ages and Renassance. Aldeshot: Ashgate Publishing Limited, 2005, p. 521-530.

ROBINSON, C. Preface do Timon. Introduction to Dialogi Luciani. Opera ominia Erasmi. I1. Amsterdam: 1969.

RODRIGUES, Rui Luis. Entre o dito e o maldito: Humanismo erasminano, ortodoxia e heresia nos processos de confessionalização do Ocidente, 1530-1685. Tese de doutorado em História Social. Orientação Laura de Mello e Souza. São Paulo: Universidade de São Paulo, 2012.

ROWLAND, Ingrid. A summer outing in 1510: religion and economics in the papal war with Ferrara. Viator. 18 (1987), p. 347-359.

RUCH, M. Le préambule dans les oeuvres philosophiques de Cicéron. Paris: Société d'Éditions "Les Belles Lettres", 1958.

RUMMEL, Erika Erasmus as a Translator of the Classics. Toronto-Buffalo-London: University of Toronto, 1985. . Erasmus on women. Toronto/Bufallo/London: University of Toronto Press, 1996.

. Humanism and the Reformation: was the conflict between Erasmus and Luther paradigmatic? in: AKKERMAN, F.; VANDERJAGT, A. J; VAN DER LAAN, A. H. (Org.) Northern Humanism in European Context, 1469-1625. From the "adwert Academy' to Ubbo Ammius. Leiden/Boston/Köln: Brill, 1999, p. 187-197.

. The Confessionalization of Humanism in Reformation Germany.Oxford Studies in Historical Theology. New York: Oxford University Press, 2000.

. The Erasmus Reader.Toronto/Bufallo/London: University of Toronto Press, 1990.

. The Humanist-Scholastic Debate in the Renaissance and Reformation. Cambridge: Havard University Press. 1998.

RUSSELL, Donald Andrew. Greek declamation. Cambridge: Cambridge University Pres, 2009. 
SALUM, Jorge. Entre Retórica, Lógica e Dialética. Aspectos da divisio nas stasis de Hermágoras e nas declamações de Sêneca o Velho. Cadernos UFS Filosofia. Fasc. XIII, vol. 8, 2010, p. 109-131.

SARTORELLI, Elaine C.; LEME, Fernando G. Erasmo, barbari, indocte docti e ciceroniani: os modelos clássicos e o ensinamento cristão. Letras Clássicas. No. 13. 2009, p. 3-28.

SARTORELLI, Elaine C. Tópica e Loci communes no Renascimento. Contexto. 2012/2, p. 255-275.

. O Elogio da Loucura, uma declamatio. II Colóquio Autores do Renascimento. 2013.

. Elementos épicos e interpretação resitucionista da História no Espelho dos Mártires. Letras Clássicas. N. 5. 2001, p. 261-276.

. Erasmo e a controvérsia ciceronia. In: Erasmo de Rotterdam. Diálogo Ciceroniano. São Paulo: Folha de São Paulo/Editora Universidade Estadual de São Paulo, 2015, p. 5-17.

SCHWARTZ, Pablo. Estratégias da Tradição: Cícero nas Declamationes de Sênca, o retor, e no Dialogus de Oratoribus de Tácito. Universidade de São Paulo. Tese de Doutorado, 2004.

. Declamación y oratória bajo Augusto: a propósito de Casio Severo, Albucio Silo y Porcio Latrón. Letras Clássicas. n. 4, 2000, p. 273-293.

SHAW, Christine. Julius II: The Warrior Pope. Oxford: Blackwell Publishers, 1993.

SHENK, Robert. "The Ancient Rhetorical Suasoria versus the Modern Technical Case". Rhetoric Review, Vol. 7, No 1., 1982, p. 113-127.

SILVA, Barbara da Costa. Tal pai, tal filho: estudoe tradução das declamações O Jovem Herói (Decla. 5) e O Velho Sovina (Decla. 6) de Corício de Gaza. Dissertação de Mestrado - Faculdade de Filosofia, Letras e Ciências Humanas, Universidade de São Paulo, São Paulo, Brasil, 2015.

SLOANE, Rhetorical Selfhood in Erasmus and Milton. JOST, Walter; OLMESDET, Wendy (ed.) A companion to Rhetoric and Rhetorical Cristicism. Oxford: Blackwell Publishing, 2004, p. 112-127.

. Schoolbooks and rhetoric: Erasmus's Copia. Rhetorica: a Journal of the History of Rhetoric. 9.2. University of Califoria Press. 1991.

SMIGELSKIS, David J. "Cultivating Deliberating: Mindfully Resourceful Innovation In and Through the Federalist Papers". In: JOST, Walter; OLMSTED, Wendy. Rhetoric in It's Place and Time. A companion to rhetoric and rhetorical criticism. Oxford: Blackell, 2004. 
SPIERLING, Ulrike; SZILAS, Nicolas (Ed.). Interactive Storytelling.First Joint International Conference on Interactive Digital Storytelling. ICIDS. Erfurt (Germany). Procedings. Berlin: Springer-Verlag, 2008.

SOTO, Sonia Braña. Modelos femininos en Las Heroidas de Ovidio. Tesis de Master. Oviedo: Universidad de Oviedo, 2012.

SOWARDS, J. K. Erasmus and the Apologetic Textbook: A Study of the "De Duplici Copia Verborum ac Rerum". Studies in Philology. Vol. 55, No. 2, 1958, p. 122-135.

. Erasmus and the Education of Women. The Sixteenth Century Journal. Vol. 13, No. 4, 1982, p. 77-89.

STORY, Luke. .The Development of Rethorical Satire in Humainsta Literature: Erasmuss The Paraise of Folly and More's Utopia. Master of Arts in English. The University of Texas at Arlington, 2012.

STRAYER, R. Western rhetoric in the Middle Ages. in: MURPHY, James (ed.). Latin Rhetoric and Education in the Middle Ages and Renassance. Aldeshot: Ashgate Publishing Limited, 2005, p. 1-26.

SURTZ, E. The Praise of Pleasure. Cambridge, Mass, 1957.

SUSSMAN, Lewis A. "The Elder Seneca's Discussion of the Decline of Roman Eloquence”.California Studies in Classical Antiquity, v. 5, 1972, p. 195-210.

TELLE, Emile V. Notes, commentaires et appendices in : ÉRASME. La Complainte de la Paix. Tradution de le Chevalier de Berquin. Notes, commentaires et appendices par Emile v. Telle. Paris-Genève: Librairie Droz, 1978.

TERPSTRA, Nicholas. Review (Erasmus on Women. Ed. Erika Rummel. The Sixteenth Century Journal. Vol. 28, No. 2, 1997, p. 696-697.

TORRES, Amadei. Las Casas e Eramso. Em signo de latim. Humanitas. Vol. XLV, 1993, p. 235-242.

TRACY, James D. Erasmus Becomes a German. Renaissance Quarterly. Vol. 21, No. 3, 1968, p. 281-288.

THOMPSON, Craig R. Introduction. The Complete Works of St. Thomas More 3, 1: Translations of Lucian. New Haven and London: Yale University Press, 1974.

. The Colloquies of Erasmus. Chicago: University of Chicago Press, 1965.

TUNBERG, Terentius. "De Erasmi Declamationibus deque declamatiuncula, quae oratio episcopi inscribitur". in: Humanistica Lovaniensia. Journal of Neo-latin studies. Volume LV. Gilbert Tournoypp (org). Leuven University Press. 2006, p. 9-17. 
De rationibus quibus homines docti artem Latine colloquendi et ex tempore dicendi saeculis XVI et XVII coluerunt. Supplementa Humanistica Lovaniensia. 1. Ed.Leuven: Leuven University Press, 2013.

. Notes on seven declamations by Erasmus. Humanistica Lovaniensia: Journal of NeoLatin Studies. Vol XLV. Leuven University Press, 1996, p. 201-244.

VAN DER POEL, Marc. Classical Mastery. The latin declamatio in Renaissance Humanism. London: Trinity College, p. 128-129.

. De declamatio bij de humanisten: bijdrage tot de studie van de functies van de rhetorica in de Renaissance. Bibliotheca Humanistica \& Reformatorica (39). Nieuwkoop, Netherlands: Hes \& De Graff, 1987.

. "The latin declamatio in Renaissance Humanism". The Sixteenth Century Journal . Vol. 20, No. 3, Autumn, 1989.

. Was Agrippa von Nettesheim and Erasmian Humanist? Acta conventus neo-Latini Hafniensis, Proceedings of the Eighth International Congress of Neo-Latin Studies, Copenhagen 12 August to 17 August 1991. Ed. by Ann Moss and others. Binghamton, New York: Medieval \& Renaissance Texts \& Studies, 1994, p. 969-977.

. The latin declamatio in Renaissance Humanism. The Sixteenth Century Journal. Vol. 20, No. 3, 1989, p. 471-478.

. Cornelius Agrippa: The Humanist Theologian and His Declamation. Leiden: Brill. 1997.

Cardano's Neronis Encomium: literary trifle or political treatise? Studi umanistici Piceni. n. 25. 2005, p. 283-291.

Material for a History of the Latin Declamation $\mathrm{n}$ the Renaissance. In: Calboli Montefusco (ed.) Declamation: Papers on Rhetoric VIII. Rome: Herder, p. 267-291.

VAN MAL-MAEDER, Danielle. La fiction des déclamations. Leiden-Boston: Brill, 2007.

VASCONCELOS, Beatriz Avila. Quatro Princípios de Ecudação Oratória Segundo Quintiliano. Phaos. Vol. 2. 2002 (2), p. 205-225. . Educação Oratória no De oratore de Cícero. Letras Clássicas. n. 4. 2000, p. 179-190.

VASOLI, Cesare. Erasmo da Rotterdam e la Cultura Europea. In: Erasmo da Rotterdam e la cultura europea. Atti dell'Incontro di Studi nel V centenario della laurea di Erasmo all'Università di Torino (Torino, 8-9 settembre 2006). Enrico Pasini e Pietro Rossi (ed.) Firenze: Edizioni Del Galluzzo, 2008, p. 3-27.

VAUCHEZ, Andreas. La spiritualité du Moyen Âge occidental, ed. du Seuil, 1994, 
VREDEVELD, Harry. The Ages of Erasmus and the Year of His Birth. Renaissance Quarterly, Vol. 46, No. 4, 1993, p. 754-809.

WEILAND, J. S.; FRIJHOFF, W. Th. M. Erasmus of Rotterdam, the Man and the Scholar. Leiden: E. J. Brill, 1988.

WEILER, Anton G. De spiritualiteit van Erasmus Christen-humanist. Nijmegen: Titus Brandsma Institutuut, 1997.

WILLIAMS, James Dale. An Introduction to Classical Rhetoric: Essential Readings. Oxford: Wiley-Blackweel, 2009.

WINTERBOTTOM, Michael. Declamation, Greek and Latin. Ars Rhetorica Antica e Nuova. Istituto di Filologia Classica e Medievale, Universitá di Genova, 1983, p. 57-76. . Declamation and Philosophy. Classica, Belo Horizonte, v. 19, n. 1. 2006, p. 74-82. . Roman Declamation. Bristol: Bristol Classical Press, 1980.

WOLF, Etienne. Déclamation et fiction historique. Théories et pratiques de la fiction à l'époque imperial. 2013, p. 269-276. 